\title{
Dynamics of Defiance: Government Power and Rural Resistance in the Arkansas Ozarks
}

\author{
J. Blake Perkins
}

Follow this and additional works at: https://researchrepository.wvu.edu/etd

\section{Recommended Citation}

Perkins, J. Blake, "Dynamics of Defiance: Government Power and Rural Resistance in the Arkansas Ozarks" (2014). Graduate Theses, Dissertations, and Problem Reports. 6404.

https://researchrepository.wvu.edu/etd/6404

This Dissertation is protected by copyright and/or related rights. It has been brought to you by the The Research Repository @ WVU with permission from the rights-holder(s). You are free to use this Dissertation in any way that is permitted by the copyright and related rights legislation that applies to your use. For other uses you must obtain permission from the rights-holder(s) directly, unless additional rights are indicated by a Creative Commons license in the record and/ or on the work itself. This Dissertation has been accepted for inclusion in WVU Graduate Theses, Dissertations, and Problem Reports collection by an authorized administrator of The Research Repository @ WVU.

For more information, please contact researchrepository@mail.wvu.edu. 
Dynamics of Defiance: Government Power and Rural Resistance in the Arkansas Ozarks

\title{
J. Blake Perkins
}

Dissertation submitted to the

\section{Eberly College of Arts and Sciences at}

West Virginia University

in partial fulfillment of the requirements

for the degree of

\section{Doctor of Philosophy}

in

History

\author{
Kenneth Fones-Wolf, Ph.D., Committee Chairperson \\ Elizabeth Fones-Wolf, Ph.D. \\ Joseph Hodge, Ph.D. \\ James Siekmeier, Ph.D. \\ Brooks Blevins, Ph.D.
}

\section{Department of History}

\section{Morgantown, WV}

2014

Keywords: Ozarks; Arkansas; rural;

government; liberal state; populism; resistance; dissent; smallholder; agrarianism; industrialization; agribusiness; liberalism; conservatism; economic development; politics; stereotypes 


\begin{abstract}
Dynamics of Defiance: Government Power and Rural Resistance in the Arkansas Ozarks
\end{abstract}

\author{
J. Blake Perkins
}

This dissertation explores the dynamics of rural resistance against government interventions in the Ozark uplands of Arkansas during the late nineteenth and twentieth centuries. It employs microhistorical analysis to delve deep into the experiences and attitudes of rural folks as they encountered and interacted with different arms of government authority during this long period of change and transition for rural America. The findings question and complicate long-held assumptions about an "exceptional" rural hill culture that supposedly eluded change and remained isolated from mainstream American developments since the pioneer settlers of the Early Republic. In particular, this work's collection of case studies probes the reasons for conflicts between rural people and government power, how hill folks perceived these conflicts, and how conflicts and attitudes changed over time.

Historians have shown a growing interest in the Ozarks in recent years. A number of them have attempted to understand how rural regions such as the Ozarks contributed to the rise of modern conservatism in America during the second half of the twentieth century. Bethany Moreton's and Darren Dockuk's works, for instance, both emphasize a continuity of rural conservativism from the first half of the twentieth century to the second. This study, however, discovers significant change and nuance in the dynamics of rural conflict with and attitudes toward government power in the Ozarks during the long twentieth century. More often than not, rural resistance sprang from a populist Left during the early twentieth century, as smallholder farmers in the backcountry saw their struggles against intrusive arms of government as stands against the self-serving capitalist elites who controlled them. By the 1960s, however, the long evolution of agricultural consolidation and industrialization in the region led to the virtual extinction of small family farms. Thousands of rural Ozarkers hit the migrant trails to Western and Midwestern cities during and after World War II, and an industrial- and agribusiness-oriented political economy that depended upon low-wage, non-union labor finally replaced the region's smallholder farm society in the backcountry. In this New Ozarks environment, town business elites and local political officials who feared a slippage of their local control led a new brand of conservative resistance that came to characterize a number of the major standoffs against government in the region during the second half of the twentieth century. Unlike the populist backcountry defiance that had shaped most rural clashes with government during the late nineteenth and early twentieth centuries, this more recent New Ozarks conservatism most resembled the tea party culture that is commonly associated with the region today.

This dissertation also contributes to a body of scholarship led by political scientist/anthropologist James C. Scott on governments' attempts to solve social problems and encourage progress. While Scott places the "high modernism" of distant bureaucracies at the center of conflicts and 
failures between governments and their people around the twentieth-century world, my work finds local disputes and uneven access to government power at the heart of the story. 


\section{Dedication}

I dedicate this work to my wife, Jodie, and our two sons, Maddox and Rylan. 


\section{Acknowledgements}

This dissertation would not have happened without the contributions of many talented and generous people. I owe a lot to my many fine professors at Lyon College, Missouri State University, and West Virginia University whose excellent teaching and examples fostered my development as a historian. They include Brooks Blevins, John Wienzierl, Edward Tenace, Bradley Gitz, Scott Roulier, Tom Dicke, Marc Cooper, Bob Miller, the late George Hummasti, William Piston, Ken Fones-Wolf, Elizabeth Fones-Wolf, Brian Luskey, Jack Hammersmith, and Mark Tauger. The social and intellectual comrarderie of fellow graduate students at MSU and WVU has also been invaluable. I would especailly like to thank Greg French, Rachel Fuller, Mary Stansfield, Hal Gorby, Jenny Turman, Adam Zucconi, Jake Ivey, Joe Super, Joe Rizzo, Josh Esposito, Karina Garcia, and Josh Howard.

I owe a big debt of gratitude to the staffs at Lyon College's Mabee-Simpson Library, Missouri State University's Duane G. Meyer Library and its Special Collections division, the Downtown Campus Library at West Virginia University, Williams Baptist College's Felix Goodson Library, the Arkansas History Commission, the Northeast Arkansas Regional Archives, the University of Arkansas Libraries' Special Collections, the Archives at the University of Central Arkansas's Torreyson Library, the Archives and Special Collections at Hendrix College's Olin C. and Marjorie Bailey Library, the Butler Center for Arkansas Studies, the University of Arkansas at Little Rock's William H. Bowen School of Law Library, the Old Independence Regional Museum, the National Archives at College Park, Maryland, and Fort Worth, Texas, and the many county couthouses and local historical societies I visited throughout the Arkansas Ozarks.

Certain indiduals who also helped in various ways with my research or analysis deserve recognition. They include James Johnston, Lynn Morrow, Steve Saunders, Patrick Williams, Lynn Gentzler, Lisa Perry, Michael Pierce, Gregory Kiser, Thomas Kiffmeyer, Bruce Stewart, Ronald Lewis, Ronald Eller, Lawrence Christenson, Matt Vester, Jackie Stites, Brian Jeffery, Don Cullimore, June Westphal, Mike Luster, Susan Mosier, and Mildred Thomas. I also appreciate all of the comments and critiques I received on academic papers related to this project that I presented at conferences hosted by the Southern Historical Association, the Appalachian Studies Association, the Society of Appalachian Historians, the Arkansas Historical Association, the State Historical Society of Missouri, the Ozarks Studies Symposium, and the Arkansas History Commission.

I could not have asked for better mentors along this journey, and, though I alone assume responsibility for all shortcomings and errors, they deserve much of the credit for whatever merits this work may have. Brooks Blevins first took me under his wing when I was an undergraduate student of his at Lyon College. In fact, this fellow rural Arkansawyer's example as a teacher and scholar most influenced my decision to pursue a career as a historian in my own right. After embarking on my path from Lyon, I was lucky enough to get to continue my studies with him in graduate school at Missouri State University, where he took a new position in 2008. His teaching, guidance, and friendship — not to mention his pathbreaking scholarship on the Ozarks - have been and continue to be indespensible, to say the least. In addition, I thank him for patiently poring over and commenting on nearly everything I have ever written and for his willingness to serve as the outside reader on my dissertation committee. I first met Ken Fones- 
Wolf, my mentor/advisor at West Virginia University, on the phone in 2010, and I was immediately drawn to his enthusiasm. I have benefitted immensely from his keen editorial eye, his interpretive insights, and his ability thoughout the writing of this work to help me see the bigger pictures when I was lost in the mountains of detail. Above all, I thank him for his constant encouragement in shepherding to me to the completion of this project. My family and I also appreciate his and Elizabeth Fones-Wolf's warm hospitality in Morgantown. Though she may not get credit for it on institutional paperwork, I also consider Elizabeth Fones-Wolf as an important mentor. On top of the ton of stuff I learned in her courses on twentieth-century America and from fruitful discussions with her about historiographical issues, she has never once hesitated to take time out of her incredibly busy schedule as chair of the History Department to advise me on academic- and career-related matters or simply to chat about family. Finally, I thank Joe Hodge and Jim Siekmier for serving on my dissertation committee and for their careful readings and insightful comments.

I received generous funding for research and paper presentations that went into this work. Amid this difficult environment in higher education of belt tightening and budget cutting by administrators across the nation, the History Department at West Virginia University has remained committed to providing the financial support its graduate students need to succeed. Two of the Department's Stuart and Joyce Robbins Fellowships enabled me to make solid progress on my research and writing by relieving me of teaching duties as a graduate instructor for two years. The Department's William D. Barns Award contributed important funding as well. Additionally, the Department funded numerous trips to conduct research and present papers at academic conferences. WVU's Elberly College of Arts and Sciences also provided travel money for research and conferences. WVU's Office of Graduate Education and Life funded a summer internship at the Northeast Arkansas Regional Archives in which I gained valuable archival experience, research opportunities, and support networks. Finally, a WVU Foundation Distinguished Doctoral Fellowship afforded important financial assistance for research.

Lastly, but most importantly, I thank my family for their many contributions and unflagging support. My mom, Royetta, has been a rock and has enthusiastically supported and assisted all of my educational endeavors, both morally and financially, throughout this whole process. Though she may have been thinking it, I appreciate her never once inquiring about why her son remained a student into his late twenties. My grandparents, Gerald and Nina Richey and Bonnie and the late Paul L. Perkins, have also given me invaluable support and encouragement. In fact, I owe my early passion for history to my fascination with their lives. I dedicate this dissertation to my wife, Jodie, and our two sons, Maddox and Rylan. Words simply cannot express how greatful I am for Jodie's love, sacrifice, and support. She has endured my career aspirations and borne far more of the load than I ever had any right to ask of her. This work would not exist without her love, labors, and support. Maddox has also been a trooper through all of this. For more than six years he has seen Dad "workin' on the computer," oftentimes hours after I should have quit for the day and given him more of my time and attention. But he should know that he is my inspiration. So too is Rylan. He came into our lives at the tailend of this journey, but his arrival during the sprint to the "finish line" has meant that he, too, has already had to share too much of Dad's divided attention. I hope that someday both he and Maddox will have a better understanding about what this labor has been for. 
Table of Contents

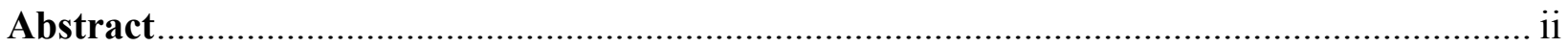

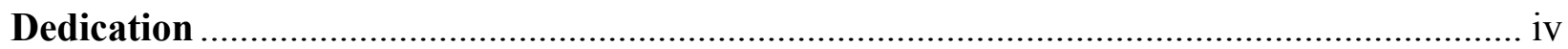

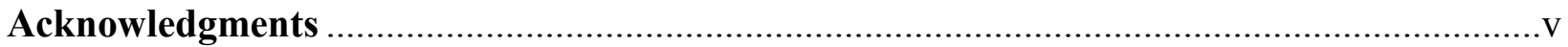

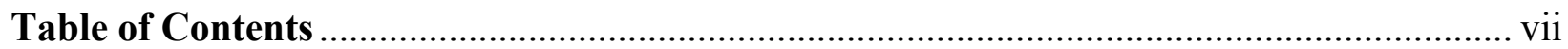

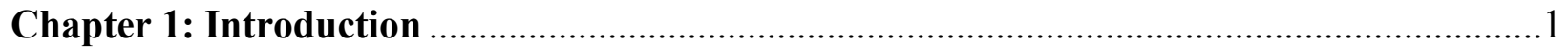

Chapter 2: The One-Gallused Crowd and the Populist Ethic ...........................................17

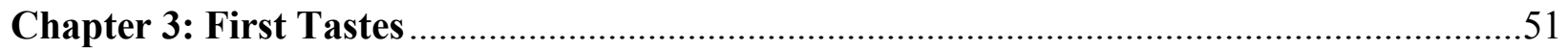

Chapter 4: Won't Serve Greedy, Un-Godly Interests .................................................111

Chapter 5: The Damn-Guvment's Tick Trouble ........................................................165

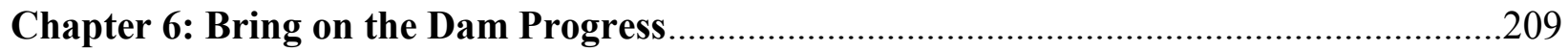

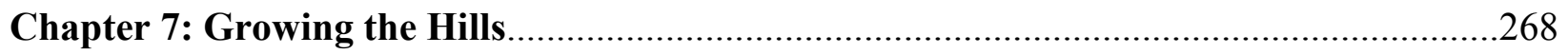

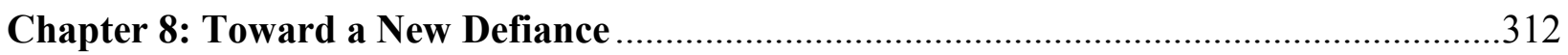

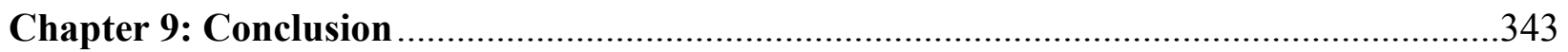




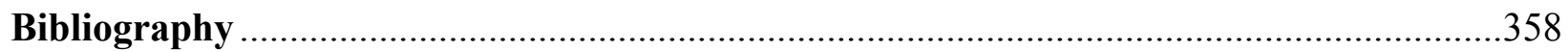




\section{Chapter One}

\section{Introduction}

On June 3, 1983, federal, state, and county lawmen surrounded the remote home of Leonard and Norma Ginter near Smithville, Arkansas, a rural village located in the Ozarks foothills. Federal authorities had received a tip that the Ginters were harboring fugitive Gordon Kahl, a militant tax protestor and anti-government extremist. Kahl had recently made the FBI's most wanted list for killing two lawmen in North Dakota. As a contingent of heavily armed officers closed in on the Ginter house, Leonard and Norma were safely and quietly taken into custody, while Lawrence County Sheriff Gene Matthews and a federal marshal wasted no time pursuing Kahl inside the home. Upon entering the house through a utility-room door, the lawmen exchanged gunshots with an obstinate Kahl, who had long promised authorities he would not be taken alive. Sheriff Matthews presumably killed Kahl with a shot to the head, but he, too, was riddled by bullets through the back and shoulder. After the federal marshal removed the mortally-wounded sheriff from the house, the army of officers standing ready on the outside unloaded a barrage of gunfire and tear gas through the walls and windows, eventually sending the Ginter home up in flames. Kahl's charred remains were later recovered from the ashes and debris, and the Ginters were sentenced to five years in federal prison. ${ }^{1}$

Media coverage of this violent incident put Smithville's rural hill community in the national headlines for the first and only time in its long history. Not surprisingly, the dramatic story conjured up popular images of rural Arkansas's isolated hill country as a bastion of

\footnotetext{
${ }^{1}$ Bernard Reed, "Shooting of Gordon Kahl," Encyclopedia of Arkansas History and Culture (encylopediaofarkansas.net), accessed August 30, 2012. For the story of Gordon Kahl, see journalist James Corcoran's Bitter Harvest: Gordon Kahl and the Posse Comitatus: Murder in the Heartland (New York: Viking Penguin, 1990). Norma Ginter's sentence was suspended and replaced with a five-year probation.
} 
exceptional anti-government sentiments. This perception, after all, dated at least to the legendary "wars" between hillbilly moonshiners and federal revenuers in the nineteenth century. New York Times columnist J.C. Barden was sure to note in his story about the shooting, though, that "far more [hill] people are unsettled by recent events than were troubled when the local criminal element turned from making moonshine to growing marijuana.” In truth, Kahl was from North Dakota and the Ginters, whose Yankee accents "sounded odd" to the locals, had recently moved into the rural community from Wisconsin. When questioned by reporters about how widespread such extreme anti-tax and anti-government sentiments were among the native hill folks, the proprietor of the nearby tractor shop said that he could only think of one local native who ascribed to such views, and that man was currently locked up "in the pen" for not paying his taxes. Likewise, the owner of the little country store in Smithville insisted that "these are not your average Arkansas people."2

The attention surrounding this late-twentieth-century gunfight in rural Smithville more broadly illuminates the tension between the popular stereotypes and assumptions about rural Ozarkers and the more layered complexities and nuances of historical reality. Since the late 1980s, historians of the southern uplands have challenged and shattered many conventional stereotypes and assumptions about rural mountain "isolation" and "otherness" by reconstructing their regions' social, economic, and cultural ties to America's mainstream developments. ${ }^{3}$

2 J.C. Barden, “Gunfight Shatters Tranquility of Arkansas Hills," New York Times, July 3, 1983; Nina Richey interview with author, Lynn, Arkansas, August 2, 2012.

${ }^{3}$ On the revision of regional "exceptionalism," see Dwight B. Billings, Mary Beth Pudup, and Altina L. Waller, "Taking Exception with Exceptionalism: The Emergence and Transformation of Historical Studies of Appalachia," in Mary Beth Pudup, Dwight B. Billings, and Altina L. Waller, eds., Appalachia in the Making: The Mountain South in the Nineteenth Century, (Chapel Hill: University of North Carolina Press, 1995). Beginning with important works by Appalachian historians such as Durwood Dunn and Altina Waller who carefully reconstructed the social dynamics of southern mountain communities, historians have shown that, despite relative geographic isolation, the 
Likewise, this study contends that the long history of conflict between government power and rural Ozarkers is a largely "unexceptional" and thoroughly American, if not universal, story.

Traditional assumptions about rural culture in regions like the Ozarks, however, have weighed heavy on recent historians' interpretations of rural Americans' interactions with and attitudes about government during the twentieth century. Two prize-winning histories, Bethany Moreton's To Serve God and Wal-Mart: The Making of Christian Free Enterprise and Darren Dochuk's From Bible Belt to Sun Belt: Plain-Folk Religion, Grassroots Politics, and the Rise of Evangelical Conservatism, for instance, place the development of modern political conservatism and popular notions of "small and limited government" in contemporary America squarely on a continuum of rural cultural traditions that date back to the nineteenth century-rural cultural traditions, in fact, that they trace directly to the Ozarks and the western South. Dochuk, in particular, points to the "pioneering ethic," "frontier thinking," and "Jeffersonian precepts" that mixed with the "conservatism" of evangelical religion to shape the late nineteenth- and early twentieth-century rural culture. Then, during the World War II- and postwar-era rural migrants carried this culture with them from the Ozarks and other parts of the western South to their new urban and suburban communities in Southern California. There these rural migrants launched

lives of mountaineers were intricately connected to the larger currents of mainstream American society and economy. See Durwood Dunn, Cades Cove: The Life and Death of a Southern Appalachian Community, 1818-1937 (Knoxville: University of Tennessee Press, 1988); and Altina L. Waller, Feud: Hatfields, McCoys, and Social Change in Appalachia, 1860-1900 (Chapel Hill: University of North Carolina Press, 1988). Also see John Alexander Williams, Appalachia: A History (Chapel Hill: University of North Carolina Press, 2002). Likewise, historian Brooks Blevins has written extensively about the "reality behind the image" of the Ozarks. See Brooks Blevins, Hill Folks: A History of Arkansas Ozarkers and Their Image (Chapel Hill: University of North Carolina Press, 2002); Brooks Blevins, Arkansas/Arkansaw: How Bear Hunters, Hillbillies, and Good Ol' Boys Defined a State (Fayetteville: University of Arkansas Press, 2009); and Brooks Blevins, Ghost of the Ozarks: Murder and Memory in the Upland South (Urbana: University of Illinois Press, 2012). 
the popular evangelical free-enterprise, "limited government" political movement that became the heart and soul of the modern Republican Party. ${ }^{4}$

Similarly, one regional historian explains the roots of modern, anti-government conservatism in the Ozarks by asserting that "individualism, often pugnacious, cantankerous individualism, has always been an Ozark trait," one directly inherited from nineteenth-century rural ideals which held that "that government governs best which governs least." Accordingly, government interventions, even those with the best of intentions, have never fared well in this tradition-defending and parochial-minded region because it has long been the domain of a rural society with a culture directly descended from what another historian calls a "distillation" of Jeffersonian libertarianism. $^{5}$

This study challenges such conventional interpretations that stress an almost linear continuity of a deeply conservative, anti-government cultural ethos in the rural Ozarks that presumably persisted with relatively little change from the nineteenth century to the present. As a work of "microhistory" —or, really, a collection of "microhistories" - it contends that historians and "social scientists have made generalizations that do not hold up when tested

\footnotetext{
${ }^{4}$ Bethany Moreton, To Serve God and Wal-Mart: The Making of Christian Free Enterprise (Cambridge: Harvard University Press, 2009); Darren Dochuk, From Bible Belt to Sun Belt: Plain-Folk Religion, Grassroots Politics, and the Rise of Evangelical Conservatism (New York: W.W. Norton, 2011), quotations on 4, 9, xx, and 13, respectively. ${ }^{5}$ Ozarks historians Bob Flanders and Paul Nagel quoted in Robert Edwards, "A Jeffersonian Distillation: The Environment of Politics," Ozarks Watch 4 (summer 1990): 22. For another example, when questioned by news reporters in 2001 about supposed "anti-federalist" and "anti-government" sentiments in the Ozarks, rural sociologist Rex Campbell emphasized the region's historically "strong independent streak, a result of [its] Scots-Irish heritage." Andy Ostmeyer, "Hate Finds a Home," reprint from newspaper article in Joplin Globe, January 2001, posted at http://www.rickross.com/reference/israel/israel6.html, accessed August 26, 2012. Furthermore, perhaps the most widely read general history of the Ozarks, geographer and historian Milton D. Rafferty's The Ozarks: Land and Life - revised and reprinted in 2001 — suggests that "the combined framework of rurality, the Upper South hill country heritage, and semi-arrested frontier supports most of the cultural baggage and popular imagery of the Ozarks: disdain for city life and education, suspicion of outsiders (especially representatives of federal and state agencies), conservative politics (whether Democratic or Republican)...clannishness... [and] independence and closeness to nature," among other "distinct" cultural traits in the region, Milton D. Rafferty, The Ozarks: Land and Life, Second Edition (Fayetteville: University of Arkansas Press, 2001), 2-3.
} 
against the concrete reality of the small-scale life they claim to explain." ${ }^{6}$ Many of the more dramatic conflicts between hill folks and government were sensationalized by twentieth-century journalists and folklore enthusiasts to create stereotypical portrayals that simplistically assumed that practically any and all cases of rural defiance sprang from an unbending anti-government hill culture. ${ }^{7}$ In addition, many historians have examined "from a distance" some of these same clashes between rural locals and government authority to reach more refined albeit similar conclusions. ${ }^{8}$ This dissertation proposes a closer reading that acknowledges important nuances in rural circumstances, experiences, and sensibilities, as well as changes over time.

\footnotetext{
${ }^{6}$ Quotation on "microhistory" from Georg G. Iggers, Historiography in the Twentieth Century: From Scientific Objectivity to the Postmodern Challenge (Hanover, NH: Wesleyan University Press, 1997), 108. For a solid overview of the historiographical practice of microhistory, see Giovanni Levi, "On Microhistory," in New Perspectives on Historical Writing, edited by Peter Burke (University Park, PA: Penn State University Press, 2001), 97-119.

${ }^{7}$ Journalists, folklorists, and other observers have long either deplored or romanticized the rural Ozarks as a bastion of rugged individualism, self-reliance, and Jeffersonian libertarianism - a land of traditional and, for many, "true" Americana. For instance, folklorist Vance Randolph explained in his 1931 book that the Ozarker of northern Arkansas and southern Missouri had long been "almost insanely jealous of his independence and personal liberty, and will fight to the death in defense of whatever he happens to regard as his rights." Vance Randolph, The Ozarks: An American Survival of Primitive Society (New York: Vanguard Press, 1931), 308. Randolph's claims were seconded ten years later by fellow folklorist Otto Ernest Rayburn, who wrote that the rural Ozarker's "fierce pride resented being told what to do and how to do it. His greatest wish was to be left alone." Otto Ernest Rayburn, Ozark Country (New York: Duell, Sloan \& Pearce, 1941), 343. James Webb's Born Fighting: How the Scots-Irish Shaped America (New York: Broadway Books, 2004) is a more recent example of the popular persistence of stereotypical rural romanticization. A former U.S. Senator (D) from Virginia, Webb's mother grew up just south of the Ozarks in the foothills of White County, Arkansas. Webb's popular history claims that a staunchly independent and authority-defying borderland culture was transplanted from the Old World by Scots-Irish immigrants during the seventeenth and eighteenth centuries in the Appalachian backcountry, where "the mountains built a fierce and uncomplaining self-reliance into an already hardened people." From there, hardy frontiersmen spread this folk culture to other parts of the South and Midwest such as the Ozarks, planting among these rural residents a permanent and resilient "determination to live under their own rules" and instilling an "unbending individualism." This ScotsIrish culture passed from one generation to the next for over two centuries, says Webb, and has naturally "conflict[ed] with a variety of authoritarian power structures, and it remains so in today's America." Webb, Born Fighting, 9, 152, 289.

${ }^{8}$ Several historians have interpreted rural resistance against government reform efforts through a modernizationversus-tradition paradigm, especially highlighting country folks' determined efforts to defend a rural cultural tradition of local control. Historian William Link's seminal work on southern progressivism in the late nineteenth and early twentieth centuries, The Paradox of Southern Progressivism, 1880-1930 (Chapel Hill: University of North Carolina Press, 1992), portrays rural opposition to the efforts of cosmopolitan-minded reformers as a "dialectic" in which "two fundamental values clashed: the paternalism of reformers and the localism and community power of traditionalists." Quotations on xii. Also see William A. Link, A Hard Country and a Lonely Place: Schooling,
} 
This study asserts that many conflicts between government authorities and hill people in the Ozarks were, more accurately, manifestations of rural folks' "populist" defiance against those privileged "elites" in their region who they believed unfairly controlled and unevenly benefitted from most of the American liberal state's power within their locales. ${ }^{9}$ Thus, this defiance did not necessarily represent a homogenous rural culture's knee-jerk reaction against and sweeping indictment of government power per se. In fact, the vast majority of poor and middling backcountry folks who typically resisted various government interventions most passionately

Society, and Reform in Rural Virginia, 1870-1920 (Chapel Hill: University of North Carolina Press, 1986). Similarly, historian Jeanette Keith's study of Tennessee's Upper Cumberland communities during the late nineteenth and early twentieth centuries, Country People in the New South: Tennessee's Upper Cumberland (Chapel Hill: University of North Carolina Press, 1995), charts the fights waged by rural "traditionalists" against reformers' attempts to remove the "structures of governance...from local hands" as they worked to instill mainstream American "progress" in the region. Quotation on page 10. This traditionalism-and-localism model generally has done much to challenge old stereotypes about an ignorant and fatalistic rural culture while also shedding important light on the often condescending attitudes of paternalistic reformers. But it, too, neglects important dynamics of social change in rural societies over time, since it emphasizes the "insularity" of rural communities that presumeably shielded them from outside influences and perpetuated the traditional ideals and localistic culture of the South's first white settlers. According to Link, for instance, the traditionalism and localism of rural southerners - a people engulfed in a culture, he claims, that was inherently "suspicious of outsiders and strongly resisted any threats to...autonomy" — was passed down over generations in a social environment where "geographical isolation combined with comparatively little emigration to produce stagnation and inertia." This was especially true, says Link, in the southern mountains, whose residents "had long been cut off from the outside world," producing isolated communities that long remained "selfsufficient cocoons, insular in attitudes and suspicious of any intrusion by outsiders." Quotations in Link, Paradox, xii and Link, A Hard Country, 12-13. Likewise, Keith's tradition-versus-modernization framework boldly—and simplistically — claims that, "in clinging to old ways, traditionalists inadvertently chose poverty" by tenaciously resisting the modernity that progressives offered. Quotation in Keith, Country People, 11, emphasis mine. Moreover, it should be noted that other historians, such as Lizabeth Cohen, A Consumers' Republic: The Politics of Mass Consumption in Postwar America (New York: Vintage Books, 2003), 227-251, have used the local-control model outside the context of rural culture to explain suburban and urban resistance to government authority. Perhaps, then, historians should rethink the usefulness of the cultural-tradition-of-local-control thesis and, instead, pay closer attention to the particular experiences and competing interests at stake in examining cases of conflict between rural people and government reform efforts.

${ }^{9}$ My use of the term "populist" or "populism" throughout this dissertation is not exclusively intended as a reference to the capital- $P$ Populist Party of the 1890 s, though, as the following chapter will argue, the broader "populist" political movement in the late 1800s and early 1900s is vital to understanding rural hill folks' views about government and its proper role. I use "populism" to describe the long, broad, and "potent tradition" of "producerist ideals" and "agrarian cosmology" that shaped rural sensibilities and the primary discourse about the role of government during the late nineteenth century and first half of the twentieth. This "populist persuasion," and its "impulse" in the rural Ozarks, in particular, called on a government "of the people" to intervene to protect and justly reward the "common people" against their "elite," "self-serving," and "undemocratic" economic and political oppressors. For a couple of important scholarly treatments on this wider view of "populism," see Michael Kazin, The Populist Persuasion: An American History (New York: Basic Books, 1995) and Jarod Roll, Spirit of Rebellion: Labor and Religion in the New Cotton South (Urbana: University of Illinois Press, 2010). 
during the first half of the twentieth century, ironically, were steeped in a dissenting populist political culture that actually called for unprecedented expansions of government power. In particular, these backcountry dissenters championed the emergence of a strengthened liberal state to help reign in the excessive inequalities and rural dispossession that accompanied the progression of industrial capitalism and agricultural centralization in the region, developments that were promoted by most local elites.

Moreton and Dochuk both address the late-nineteenth- and early-twentieth-century populist impulse in the rural Ozarks and surrounding areas, but they generally concur with the eminent post-World War II “consensus” historian Richard Hofstadter's contention that rural Americans were more or less reacting to "status" anxiety and never offered any serious suggestions for reform. Dochuk seems to believe that populism's most significant legacy was in teaching these like-minded "radical individualis[ts]" who were "inspired by the mythologized ideal" of Jeffersonian democracy to rally together for the sake of lobbying for and promoting their own parochial interests. Moreton goes even farther in arguing that the "procorporate" conservatism found in today's Ozarks should be traced directly to the rural "populist heritage" that came out of the 1890s. She claims that late-nineteenth-century "Populist-style cooperatives" and other forms of agrarian organizing were not really progressive anti-corporate movements intended to advance legitimate reforms to American capitalism. Rather, for Moreton, these populist organizing campaigns represented what were actually the efforts of self-interested, incipient rural capitalists who wanted to forge "large-scale" agricultural monopolies in the their own right. Such an interpretation, however, seems akin to equating urban working-class members of labor unions with the Robber Barons and their corporate industrial monopolies, thus negating the analytical conception of economic class conflict. Instead, my interpretation in this 
work adheres more closely to the general consensus among most recent historians of latenineteenth- and early-twentieth-century agrarian populism which holds that increasingly displaced small farmers genuinely mobilized in "an economic and social movement for change" and "offered an alternative vision" for rural America. ${ }^{10}$

In the Ozarks, it was only during the second half of the twentieth century, after many distasteful and disappointing encounters with government reform efforts and after remarkable economic and social transformations, when standoffs between hill folks and the liberal state more frequently took the shape of the conservative laissez-faire resistance to "Big Government" that is commonly associated with the region's political culture today. Even then, the most active expressions of this more recent anti-government resistance were usually instigated and led by disgruntled New Ozarks elites who advocated "business freedom" and preserving the local power structure above all else and rarely by poorer and middling rural folks themselves. This more recent "grass-top" movement stood in contrast to the older, grassroots-oriented dynamics of rural defiance in the early twentieth century. ${ }^{11}$

\footnotetext{
${ }^{10}$ Richard Hofstadter, The Age of Reform: From Bryan to F.D.R. (New York: Vintage Books, 1955); Dochuk, From Bible Belt to Sun Belt, 9-13; Moreton, To Serve God and Wal-Mart, 15-16, 29; James M. Beeby, "Introduction: Populism in the American South," in Populism in the South Revisited: New Interpretations and New Departures edited by James M. Beeby (Oxford, MS: University Press of Mississippi, 2012), xii, xvii. For an especially powerful argument which posits that small farmers in the South and Midwest - even more so than urban workerswere the key political constituencies responsible for advocating the origins and expansion of America's modern liberal state in the early twentieth century, see Elizabeth Sanders, Roots of Reform: Farmers, Workers, and the American State, 1877-1917 (Chicago: University of Chicago Press, 1999).

${ }^{11}$ My use of the term "New Ozarks" is a regional adaptation of Southern historians' longtime use of a post-Civil War-era "New South" analytical conceptualization, which is often employed to juxtapose the competing trajectories of a "new" order characterized by industrialization and centralized agriculture versus a traditional smallholder agrarian society. See, for instance, C. Vann Woodward, Origins of the New South, 1877-1913 (Baton Rouge: Louisiana State University Press, 1951); George B. Tindall, The Emergence of the New South, 1913-1945 (Baton Rouge: Louisiana State University Press, 1967); and Edward L. Ayers, The Promise of the New South: Life After Reconstruction (New York: Oxford University Press, 1992).
} 
This dissertation also grapples with and contributes to the growing discussions among historians and social scientists, led by political scientist and anthropologist James C. Scott, about why governments' liberal reform efforts during the long twentieth century have frequently missed their marks in winning the support of and improving the conditions of dispossessed peoples, especially in rural societies. Scott's Seeing Like a State: How Certain Schemes to Improve the Human Condition Have Failed examines a number of twentieth-century state reform efforts across the globe and concludes that the "high modernism" of distant bureaucracies typically caused what were otherwise hopeful and well-intended programs to fail. "High modernist" bureacrats, says Scott, primarily aimed to utilize the largely unrestricted machinations of state power to simplify the ordering of society and nature in ways that better enabled them to achieve their quest for "scientific" and "progressive" administration. But "modern statecraft" often met with disaster among local populations. According to Scott, this generally happened because the disconnected and "muscle-bound" political leaders and scientific experts who were in charge of government reform efforts sought an overly simplistic "administrative order of nature and society" that attempted to make "legible" what were really particularly messy and complex social problems. Government bureaucrats, then, all too often implemented one-size-fits-all policies that were made in the image of and according to the values and "interests" of the "high modernists" themselves. This handing down of reform mandates and programs to locally diverse peoples and communities from distant, out-of-touch capital cities necessarily entailed "an imperial or hegemonic planning mentality that excludes the necessary role of local knowledge and know-how," writes Scott. Hence, such approaches frequently stoked determined resistance, or met disengaged apathy at best, from the dispossessed populations who 
reformers intended to help. Historians of rural America have made similar arguments regarding agricultural, conservation, educational, and other social reform programs. ${ }^{12}$

This dissertation concurs with Scott's assertion that governments' "formal schemes of order are untenable without some elements of the practical knowledge that they tend to dismiss." ${ }^{\prime 13}$ This holds especially true in the rural Ozarks, where the realities of hill folks and their experiences have long been misunderstood and neglected beneath the clouding of exaggerated cultural stereotypes and assumptions. Nevertheless, on the other hand, this work also pushes historians to reconsider the "high modernist" critique's typically less critical evaluation of "decentralization" and "local control" in their analyses of governance and social reform efforts. In the rural Ozarks, in fact, most government-administered social reforms closely abided by the strong political traditions of "federalism" and "localism" in the United States, in which the powers of government reform were significantly shared—and, in many cases, outright controlled—-by local and regional leaders.

The stories of "damn guv'ment" defiance recounted in this dissertation suggest that, at least prior to the 1960s, rural resistance against many of the liberal state's most intrusive reform programs was more often aimed at well-to-do local and regional elites and their New Ozarks industrial and agribusiness agendas than at "high-handed" officials in Washington. Indeed,

\footnotetext{
${ }^{12}$ James C. Scott, Seeing Like a State: How Certain Schemes to Improve the Human Condition Have Failed (New Haven: Yale University Press, 1998), 1-8. For a sampling of recent histories of rural America that embody the strong influence of Scott's "high modernism," see Catherine McNicol Stock and Robert D. Johnston, ed., The Countryside in the Age of the Modern State: Political Histories of Rural America (Ithaca: Cornell University Press, 2001); Karl Jacoby, Crimes Against Nature: Squatters, Poachers, Thieves, and the Hidden History of American Conservation (Berkeley: University of California Press, 2001); Jeanette Keith, Rich Man's War, Poor Man's Fight: Race, Class, and Power in the Rural South during the First World War (Chapel Hill: University of North Carolina Press, 2004); and Claire Strom, Making Catfish Bait Out of Government Boys: The Fight Against Cattle Ticks and the Transformation of the Yeoman South (Athens: University of Georgia Press, 2009).

${ }^{13}$ Scott, Seeing Like a State, 7.
} 
contrary to stereotypical imagery and lore, many rural Ozarkers persistently expressed hope in the "people's" government to exercise a larger role in filing down the sharp edges of an increasingly capital-intensive political economy that threatened their families' security and sustainability, and in its ability to redistribute wealth and power from "self-serving" elites to "common folks" - namely small-scale producers such as their own. Despite these hopes, they persistently encountered a number of government reform efforts that left them either enraged or disappointed, since the liberal state delegated most of its power to their primary antagonists, New Ozarks elites. Because they were often designed to serve local elites' visions of industrialization and agricultural centralization, many government programs failed to "trickle out" to the poor and middling rural folks they were intended for. ${ }^{14}$

In many ways, rural people's experiences with government power in the Ozarks paralleled those of rural populations in other parts of the world. The nearly two-hundred-year story of "governmentality" in Indonesia's rural Sulawesi highlands is a case in point. Anthropologist Tania Murray Li's The Will to Improve: Governmentality, Development, and the Practice of Politics shows that state interventions - both colonial and postcolonial — designed to promote progress and improve the lives of those highlanders rarely ever met their intended goals. In fact, many government interventions actually exacerbated problems and produced unintended consequences that inflicted even greater detriment to rural families and communities, prompting new crises in which the state frequently felt the need to subsequently intervene again. Li,

\footnotetext{
14 Throughout this work, I use terms such as “elite," “well-to-do," "boosters," and "prosperous" Ozarkers to describe a local and regional class of prominent town businessmen, comparatively large landowners and more highlycapitalized farmers than average hill folks, and those people most politically and economically connected to them and their interests. I use "backcountry folks," "smallholders," "yeomen," and "family farmers" to refer to rural people with small or mid-sized landholdings, relatively small cash incomes, little access to investment capital, and, more generally, those less fortunate Ozarkers who frequently found themselves dispossessed in an increasingly industrial- and agribusiness-oriented political economy during the late nineteenth and twentieth centuries.
} 
however, locates the failures of these government reform efforts less in the "high modernist" designs of distant bureacracies, as James C. Scott would have it, and more in how the programs were ultimately implemented at the local level. In particular, Li contends that in most of these government efforts many of the most meaningul reform elements disappeared in the compromises that reformers made to win their programs' approval within the established political systems.

Importantly, reformers negotiated and collaborated with elites who controlled the local structures of power in the Sulawesi highlands and held a vested interest in the status quo. In doing so, the actual administration and implementation of government programs, which local elites typically assumed control over, inevitabley strayed from the most reform-spirited aims of their designers' original proposals. Meanwhile, for their part, the Sulawesi highlanders who the programs were intended to help, exhibited a remarkable "will to improve" and openness to reform. In most cases, though, not only did the politically-diluted government programs fail to uplift the rural commoners they were intended for, but they also wound up strengthening the elites' grip on the local structures of power. Therefore, many government interventions inadvertently helped widen social, political, and economic inequalities in the Sulawesi highlands even more and, consequently, provoked stiff rural resistance. ${ }^{15}$ This study unveils a similar pattern in the rural Ozarks. Like Li's work, this history of the rural Ozarks attempts to correct an over-emphasis on the blunders of interventionist bureaucracies in studies of government power by shifting more of the focus, instead, on the local and regional levels where government power was implemented and its real consequences played out in people's lives.

\footnotetext{
${ }^{15}$ Tania Murray Li, The Will to Improve: Governmentality, Development and the Practice of Politics (Durham, NC: Duke University Press, 2007).
} 
In the first five chapters that follow this introduction, I contend that hill folks' populist, anti-elitist sensibilities are the key to understanding the rural dynamics of defiance against government power in the Arkansas Ozarks during the first half of the twentieth century. Chapter 2 sets the stage by probing the "populist ethic" that fired up the grassroots amid the Gilded Age's growing inequalities and rural dispossession. It was this populist defiance that informed most rural Ozarkers' opinions about the proper role of government and that shaped their dispositions and responses to government reforms that conflicted with their visions and goals of smallholder security and sustainability over the next several decades. Chapter 3, titled "First Tastes," delves deep into the infamous battle over moonshine liquor in the Ozarks, that clash between certain hill folks and government power that probably did more than anything else to construct the stereotype of an exceptional authority-defying hill culture in the American popular consciousness. This was much more than a simple story of rural locals resisting uninvited intrusions by government outsiders, though. The conflict was really one between struggling backcountry farmers and their efforts to get ahead and stay ahead amid increasingly grim prospects for small family farmers on the one hand, and, on the other, the local elites in the region who instigated and administered this government regulatory power to crack down on liquor manufacturing in the name of progress and prosperity.

Chapter 4 examines the forgotten history of one of the most dramatic stands against government power in the early-twentieth-century Ozarks: rural resistance to the military draft during the First World War. While federal, state, and local officials worked diligently to invoke a spirit of national unity, citizenship, and service to country, a number of backcountry Ozarkers refused to participate in a war that they believed had been unjustly conjured up to pad the pockets of the elite "silk-hatted fellers." Chapter 5 looks at a government policy which aimed to 
improve farming practices in the region, particularly a tick eradication program designed to promote healthier livestock and more lucrative cattle raising opportunities. While officials in the US Department of Agriculture and the state government assumed that the tick program would receive unanimous support from all farmers, they soon encountered the opposition of many poor and middling backcountry people who found eradication far more costly than beneficial. These small farmers scorned and, in some cases, violently resisted the program because it was administered by and for the benefit of more prosperous farmers in the region at their expense. Then, Chapter 6 takes the story of rural egalitarian, anti-elitist defiance into the Great Depression of the 1930s, which, as it turned out, proved to be smallholder agrarian-populism's last major political stand in the Ozarks. Most Ozarkers supported a stronger, more interventionist American state, hoping that some long-awaited economic justice might finally come to their rural communities. But New Dealers, acceding to the tradition of "local control," passed most implementation of the federal government's newly-expanded authority and resources to regional and local elites who had little interest in helping preserve a family farm economy but, instead, used this power to advance their own New Ozarks vision of "dam progress" as a means to promote industrialization and agribusiness.

The final chapters take the story into the transformative period that followed World War II. By the 1960s, thousands of backcountry Ozarkers had abandoned their opportunity-strapped smallholder farming communities to join one of the largest mass migrations in American history. Those rural folks who they left behind in the region were counted among the most impoverished people in the country, even amid postwar America's booming affluence. Chapter 7 documents how many Ozarkers hoped that the "economic growth" agenda of the Kennedy and Johnson administrations might fulfill its promise to "develop" the region's way out of poverty. But they 
were quickly disappointed by the limitations of the government's regional development program and its uneven assistance that favored a handful of already-prosperous "growth centers" at the expense of smaller and poorer rural Ozarks communities and small towns. Meanwhile, the federal government's attempts to tackle poverty "from the bottom up" encountered stiff resistance. Chapter 8 looks at the determined criticism and opposition in the region to the federal government's War on Poverty. Unlike the rural defiance of backcountry folks documented in earlier chapters, however, it finds that the loudest objectors and instigators of opposition were New Ozarks elites who resented the federal anti-poverty programs' threats to their local control and the malleable, low-wage labor force upon which their new tourism-, light-industrial-, and agribusiness-based economy depended. Contrary to popular myth, this new dynamics of defiance in the 1960s and 1970s, it suggests, had far more in common with today's antigovernment tea party culture than did backcountry Ozarkers' "damn-guvment" resistance in the late nineteenth and early twentieth centuries.

It seems almost cliché for authors of works that use "case studies" such as this to set forth "disclaimers" up front to remind readers of their limitations. But it seems fitting to do so here as well. Historian Durwood Dunn, whose own study of a particular Appalachian community helped refocus the entire historiography of the Upland South, has rightly noted that writing casestudy history often comes with "critical limitations on forming broader generalizations about the region as a whole," especially since we must consider the "uniqueness of...individual mountain 
communities." ${ }^{\prime 16}$ Indeed, there is no guarantee that all of the case studies contained in this work represent the experiences of all Ozarkers.

On the other hand, though, how can we begin to test the validity of generalized assumptions about history without zeroing in on and peeling back the complex layers of specific local experiences? This is a challenge that historians of all peoples, places, and time periods face, but it is an especially tall order for historians of the Ozarks, a region with a history that has long been obstructed by "the thicket of myth, nostalgia, and stereotype." Historian Brooks Blevins has recently advised the region's historians to "not be held captive by generations of stereotyping and generalization" and to "avoid building our histories on a faulty foundation." 17 I see no better way to do this than by putting local people and their grassroots experiences under the microscope of historical inquiry. In this work, I have mindfully worked to connect the local and general, the regional and American, the immediate-term and long-term, and have striven to weave together the often overly-compartmentalized analytical lenses of political, social, economic, and cultural history. In doing so, my hope is that this collection of microhistorical studies of rural hill folks' experiences with government power over a relatively long period of time will shed some important light on not only a forgotten history of the Ozarks but also, more broadly, on a forgotten history of America - and, perhaps, even the global experience. At least maybe it will raise important questions and help invite others to debate and write new historical narratives that broaden our understanding, for the lessons seem rich.

\footnotetext{
${ }^{16}$ Dunn, Cades Cove, xiv-xv.

${ }^{17}$ Blevins, Hill Folks, 7; Brooks Blevins, "Considering Regional Exceptionalism: The Case of the Ghost of the Ozarks,” Missouri Historical Review 107 (January 2013): 74.
} 


\section{Chapter Two}

\section{The One-Gallused Ozarkers and the Populist Ethic}

On a hot summer day, July 4, 1899, more than three thousand Ozarkers descended upon the town of Hardy in Sharp County (the setting of the Discovery Channel's recent "reality" TV show Clash of the Ozarks) to take part in the local Independence Day celebration, one of the most anticipated social events of the year. Many folks undoubtedly enjoyed overdue visits with friends and acquaintances, some rare courting opportunities between young folks of the opposite sex, an array of festivities and food - not to mention, for at least some, a good-sized swig or two, or nine or ten, of white lightening — and all of the other activities that were customary of such Fourth of July celebrations throughout America. At the end of the day, these rural folks gathered around "a makeshift grandstand" for the celebration's main event, a fiery speech made by state attorney general Jeff Davis — the "Wild Ass of the Ozarks," as Davis's political detractors frequently called him. In firing the opening shots in his candidacy for the next gubernatorial race, Davis lamented the unjust inequalities and gross imbalance of power that had come to characterize Gilded Age America and Arkansas. "Divide the country into two classes: wealth producers and wealth consumers," he exhorted. "Wealth producers are the most numerous, but the wealth consumers are the lawmakers." "Under such conditions can we be free to enjoy our right to the pursuit of happiness? Do you suppose our ancestors who planted here in virgin soil the tree of liberty would recognize this country today?" Davis asked. "Would they ever have 
thought that the principles of this government would be so warped and distorted as to give us the miserable thing we have today?"1

The "Karl Marx for Hill Billies," as a noted southern scholar later referred to Davis, likely drew impassioned ovations from his rural audience as he lampooned the state legislature for always bowing to the interests of railroad companies and other corporations, and when he scolded an Arkansas supreme court that had recently "ruled against the people" by blocking his office's efforts to prosecute trusts and monopolies operating within the state. Davis likewise chastised the U.S. Supreme Court for striking down the new federal income tax law that had been headed up by William Jennings Bryan and passed by Congress in 1894. He charged that the court's decision was an undemocratic and high-handed conspiracy concocted "for the benefit of aggregated wealth...[so] that the wealthy should not pay taxes on their surplus incomes, although the people said they should." And he also warned that the plan being drawn up by politicians at Little Rock to build a new statehouse was bound to become "the most infamous steal ever perpetrated against the people of Arkansas," because the self-serving and manipulative masterminds behind it, he claimed, were secretly scheming a lucrative real estate deal to benefit one of Little Rock's wealthiest and most influential families. Davis concluded this "first speech of the most memorable political campaign in the state's history" by assuring the "crowd of leathery-skinned, one-gallused dirt farmers" that he was "in this fight for the people and I shall not desert them...I intend to tell the people the truth in each of the 75 counties of the state and before the canvass for the governorship is over you will not be able to see me for the dust." "The

\footnotetext{
1 "Davis at Hardy," Arkansas Gazette, July 5, 1899; Raymond Arsenault, The Wild Ass of the Ozarks: Jeff Davis and the Social Bases of Southern Politics (Philadelphia: Temple University Press, 1984), 3, 77.
} 
war is on, knife to knife, hilt to hilt...between the corporations... and the people," he told rural Arkansawyers in another speech. ${ }^{2}$

As the Pulitzer Prize-winning poet and Little Rock native John Gould Fletcher wrote nearly a half-century later, "It was the mountain people who had produced Jeff Davis; from the beginning of his career to its end, he was their spokesman and their champion."3 Davis's popularity in Arkansas's mountain counties, of course, did not alone account for all of his subsequent success at the polls, but tapping hill folks' sentiments about government and its proper role at least helped ensure that he would never lose another election. He went on to serve three terms as governor and then as a U.S. senator until his untimely death in January 1913. Despite a much stronger penchant for campaigning than policymaking, Davis's powerful political discourse embodied the populist ethic that had come to shape rural attitudes and ideas about government during this era of sweeping social and economic change. Popular imagery of mountain isolation, insularity, and parochialism belied the fact that rural Ozarkers stood right in the thick of Gilded Age America's social, economic, and political developments.

Like other rural Americans "who felt trapped in an order dominated by big business" and now found "unconvincing the old gospel of laissez-faire," most rural Ozarkers championed drastic expansions in government power, particularly new interventions in the economy, to ensure fairness and protection against the vagaries of capitalist-controlled markets. Meanwhile, they resisted certain arms of governmental authority that they believed unjustly catered to the

\footnotetext{
${ }^{2}$ Rupert Vance, “A Karl Marx for Hill Billies," Social Forces 9 (December 1930); "Davis at Hardy”; Arsenault, The Wild Ass of the Ozarks, 77-79; Raymond Arsenault, "Jeff Davis (1862-1913)," Encyclopedia of Arkansas History and Culture (http://www.encyclopediaofarkansas.net/encyclopedia/entry-detail.aspx?entryID=98).

${ }^{3}$ John Gould Fletcher, Arkansas, John Gould Fletcher Series, vol. 3 (1947; Reprint, Fayetteville: University of Arkansas Press, 1989), 261.
} 
"special interests" of well-to-do elites, demanding that common working folks like themselves reclaim the rule of the public realm in accordance with America's "pure" democratic ideals. A "populist persuasion" could appeal to the interests of country and town folks, poor dirt farmers and prosperous local elites alike. But many dispossessed backcountry folks would emerge from the 1890s political insurgency ready to direct their rural defiance not only against unjust outsiders but also against well-to-do local elites who controlled the increasingly capitalistoriented economic and political structure in the region. ${ }^{4}$

Contrary to popular imagery of mountain isolation and quiescence, America's emerging industrialization had created major changes in the rural Ozarks by the turn of the twentieth century, even as the rural region remained on the national political-economy's periphery. Government—federal, state, and local—had played no small role in helping precipitate these changes. Arkansas Republicans during Reconstruction, who received some of their strongest support from mountain Unionists in certain enclaves of the western Ozarks, ascribed to a "gospel of prosperity" and worked to employ government resources to build "a society of booming factories, bustling towns, a diversified agriculture... and abundant employment opportunities." To accomplish these ends, Arkansas Republicans raised new taxes to build the state's first public and higher education systems. They created and funded the activities of Arkansas's Commission of Immigration and State Lands, which worked to attract new labor and investors by advertising the state's abundance of land (much of it free or below market prices through the federal Homestead Act of 1862 and other government programs) and resources to potential developers.

\footnotetext{
${ }^{4}$ Michael Kazin, A Godly Hero: The Life of William Jennings Bryan (New York: Anchor Books, 2006), quotation on 149.

${ }^{55}$ Thomas DeBlack, “'A Harnessed Revolution': Reconstruction in Arkansas,” in Arkansas: A Narrative History, ed. Jeannie M. Whayne, et al, (Fayetteville: University of Arkansas Press, 2002), 217.
} 
Moreover, Arkansas Republicans during Reconstruction embarked upon an unprecedented number of state-sponsored infrastructure development projects, especially railroad construction. ${ }^{6}$

Many of these government programs helped lay the early foundations for new economic developments in the years ahead, but state and local Republicans' affinity for the spoils of patronage and their frequent overextension of resources, as well as backroom deals between "ambitious entrepreneurs and unscrupulous politicians" amid their government-funded development schemes, opened them to staunch criticism, even within their own party ranks. Factionalism between the state's Republican Party machine and insurgent "native Arkansas Unionists"-initially led by Ozarker James Johnson of Madison County—combined with the federal government's waning commitment to southern reconstruction to eventually open the door for conservative Democrats to regain control of the state in 1874. This new leadership promised to "redeem" Arkansas from Republicans" "carpetbagger," "scalawag," and "negro" rule and, thereby, to restore a government by and for "the people.,"7

“Redeemer" Democrats in Little Rock immediately distanced Arkansas as much as possible from most forms of federal authority, in accordance with their "states rights" agenda. They also went to work decentralizing the state government and slashing taxes and funding for state services - policies that "would well serve the interests of the state's landed elite far into the next century." But, as historian C. Vann Woodward has noted, a "New Order" was afoot, one that ensured that government would continue playing key roles in promoting economic and

\footnotetext{
${ }^{6}$ Ibid., 218.

${ }^{7}$ Ibid., 218, 227, 237-239.
} 
social changes throughout the rural South, including the Ozarks. ${ }^{8}$ Despite such "relatively laissez-faire" and more locally-controlled governance, "the interconnections of commerce and state making" greatly impacted the development of a changing social, economic, and political order in the southern mountains. ${ }^{9}$

Indeed, even conservative "Redeemer" political leaders were generally unanimous in their eagerness to promote new economic development in Arkansas. Particularly, they "coveted the iron horse as the key to commercial prosperity" and issued government land grants to railroad companies in excess of a million acres during the late nineteenth century. Meanwhile, they fixed low tax rates and engineered favorable property assessments as parts of incentives packages to lure industrial investments. Railroad construction in Arkansas rapidly rose from 256 miles of track in 1870 to more than 2,200 miles by 1900, and many more miles of main- and spur-lines were added during the first two decades of the twentieth century. ${ }^{10}$ Although railroad building often progressed slower and with more difficulties in the rugged Ozarks, five main railroad lines and numerous subsidiary and spur lines traversed the region by 1920. Larger towns and commercial centers drew most of the "growth" generated by railroad building in the region. But many of those smaller and less populated trading centers that remained at a relative distance from the tracks also hoped to bring new "prosperity" to their locales and went to work on the often laborious and expensive task of building and improving overland roads through the

\footnotetext{
${ }^{8}$ Ibid., 239; C. Vann Woodward, Origins of the New South, 1877-1913 (Baton Rouge: Louisiana State University Press, 1951), 155. On Arkansas specifically, see Carl H. Moneyhon, Arkansas and the New South, 1874-1929 (Fayetteville: University of Arkansas Press, 1997), 23-40.

${ }^{9}$ Dwight B. Billings and Kathleen M. Blee, The Road to Poverty: The Making of Wealth and Hardship in Appalachia (Cambridge, UK, and New York: Cambridge University Press, 2000), 23, 105.

${ }^{10}$ Michael B. Dougan, Arkansas Odyssey: The Saga of Arkansas from Prehistoric Times to Present (Little Rock: Rose Publishing Company, 1994), 282; Jeannie M. Whayne, "Prosperity Eluded: Era of Transition, 1880-1900," in Arkansas: A Narrative History, ed. Jeannie M. Whayne, et al, (Fayetteville: University of Arkansas Press, 2002), 248-249.
} 
hills and valleys to connect to the nearest train depots. ${ }^{11}$ As was the case in Appalachia, even the Ozarks" "remote interior was [more thoroughly] integrated into the national economy as industrial capitalism unlocked the storehouse of natural resources."12

Late-nineteenth- and early-twentieth-century "development" and "progress" connected the rural region more fully to the national and international economy than ever and brought new market opportunities to the region. Most rural Ozarkers hoped that the new cash incomes generated from these market opportunities would help them sustain their smallholder, familyfarm society and the relative independence it afforded. Many rural Ozarkers who in the postCivil War era "found themselves no longer alone in a sparsely settled country but increasingly surrounded by other small farms" were especially hopeful that these new markets might improve prospects for shoring up and reproducing family-farm life amid growing population pressure and an ever constricting availability of "open” and productive land in the region. ${ }^{13}$ Converting significant parts of farm production to raising specialized cash crops, taking "off-farm" work in the region's growing timber industry to supplement smallholder incomes, and selling mineral and timber rights to budding entrepreneurs and prospectors seemed a timely solution to advance their small farms' sustainability and security. ${ }^{14}$

\footnotetext{
${ }^{11}$ Blevins, Hill Folks, 34, 81.

${ }^{12}$ Ronald L. Lewis, Transformation of the Appalachian Countryside: Railroads, Deforestation, and Social Change in West Virginia, 1880-1920 (Chapel Hill: University of North Carolina Press, 1998), 7.

${ }^{13}$ Ibid., 47. By 1900 "the Census Bureau found more than 35,000 farms in the fifteen Ozark counties, an increase of 90 percent in just the previous two decades," writes Blevins. Blevins, Hill Folks, 48.

${ }^{14}$ On industrialization and the expansion of commercial agriculture in the southern uplands, see Steven Hahn, The Roots of Southern Populism: Yeoman Farmers and the Transformation of the Georgia Upcountry, $1850-1890$ (New York: Oxford University Press, 1983); Lewis, Transformation of the Appalachian Countryside; and Robert S. Weise, Grasping at Independence: Debt, Male Authority, and Mineral Rights in Appalachian Kentucky, 1850-1915 (Knoxville: University of Tennessee Press, 2001). On the Arkansas Ozarks in particular, see Blevins, Hill Folks, 63-89.
} 
Industrialization in the Ozarks, however, assumed a largely "extractive" nature, as industrialists primarily aimed to exploit the region's natural resources and cheap agricultural products and labor. Though industrialists and their regional "boosters" were fond of trumpeting their contributions to job creation and expanding economic opportunities for local populations, these exctractive tendencies meant that the lion's share of industrial profits were actually carried out the region. The new economic environment provided very little "value-added" improvements and opportunities for local communities that might have led to greater "selfsustaining development" in the region. Much like Appalachia, the Ozarks emerged as a "periphery region of uneven economic development" in the nation's capitalist economy. ${ }^{15}$

With the new economic developments in the region, furthermore, came increased vulnerability for small farmers in the rural backcountry. Ironically, some of the very same market opportunities that rural folks pursued as they "grasped" for yeoman independence all-toooften left them more extensively dependent on market forces beyond their control and subjected them to the boom-and-bust vagaries of laissez-faire capitalism. An unprecedented reliance on unpredictable "cash crop" market prices, vicious cycles of merchant credit, and exorbitant freight rates charged by railroad companies and other "middle men" had many small farmers in the rural Ozarks second-guessing the new and increasingly unequal economic environment—particularly, the elite "boosters" who controlled it—by the last years of the nineteenth century. With the region's small farmers more tightly ensnared in unforgiving market forces dictated by the "natural laws" of supply and demand that inevitably favored larger and more highly-capitalized

\footnotetext{
${ }^{15}$ Blevins, Hill Folks, 69-89. For a good discussion on the history and historiography of industrialization in Appalachia, see Ken Fones-Wolf, Glass Towns: Industry, Labor, and Political Economy in Appalachia, 1890-1930s (Urbana: University of Illinois Press, 2007), xxii-xxv.
} 
producers, farm tenancy in the Arkansas Ozarks rose by nearly one-fifth during the last two decades of the nineteenth century alone. But tenancy statistics alone do not tell the full story. Backcountry farmers who managed to hang on to their farms often had to do so by expanding their agricultural production to poor lands "previously deemed unsuitable for cultivation" and continued to fight a rearguard defense for smallholder sustainability. ${ }^{16}$ The Ozarks timber boom provided a number of small hill farmers some temporary relief in the form of supplemental cash incomes. When the timber companies finished extracting the profitable stands of timber in an area and moved on to the next, however, this "off-farm" income largely disappeared. In its wake, the timber companies carried most of the profits outside the region and left behind little but a "cut-over wasteland" for struggling small farmers to try to scrape by on. ${ }^{17}$

Consequently, rural discontent arose forcefully in the region during the last decades of the nineteenth century. Thousands of small farmers began forming local "lodges" to discuss their common troubles and to demand change. The Brothers of Freedom (B of F), originally founded in rural Johnson County in 1882, emerged primarily in the region's western and central counties as one of the largest and best-organized "unions" of farmers in the Arkansas Ozarks in the 1880 s. Committing itself to the cause of the common working men who "are gradually becoming oppressed," the B of F condemned the "combinations of capital" and the big-moneyed interests "who propose not only to live on the labors of others, but to speedily amass fortunes at their expense." Combining a "mountain-grown blend of scripture" with America's founding ideals, the organization's "Declaration of Principles" proclaimed that "We believe there is a God,

\footnotetext{
${ }^{16}$ Blevins, Hill Folks, quotation on 48.

${ }^{17}$ On the timber boom in the Arkansas Ozarks, see Blevins, Hill Folks, 75-82. For an outstanding comparison on the timber industry in rural West Virginia, see Lewis, Transforming the Appalachian Countryside.
} 
the great Creator of all things, and that he created all men free and equal, and endowed them with certain inalienable rights, such as life, liberty, and the pursuit of happiness, and that these rights are a common inheritance and should be respected by all mankind." 18

B of F organizers, led by Ozone resident Isaac McCracken, succeeded in tapping the discontent of many Ozarks hill farmers and in lending a new collective voice to their demands for reform. Contrary to popular portrayals of backwoods mountain folks' presumably reflexive suspicion of any and all outsiders, McCracken, the farm organization's president, was a Canadian-born "furriner" who had recently migrated to the region. As a young boy, McCracken and his family had moved to Massachusetts, where he grew up and got his first job working on a whaling ship. After three years at sea, McCracken apprenticed himself to a machinist back in Massachusetts in 1863. Shortly after the Civil War, McCracken headed west to Wisconsin, where he married and started a family, and then ventured to Minnesota for a brief spell. The McCrackens then migrated south to homestead a small farm in the "back-country of Johnson County" in the Arkansas Ozarks. McCracken worked primarily as a smallholder farmer there, except for a two-year hiatus when he went to Little Rock to earn wages as a machinist. While in Little Rock, McCracken picked up some valuable organizing skills as a member of the Blacksmiths' and Machinists' Union. Despite his outsider status, many local rural folks in Johnson County and eventually throughout the region grew to admire and trust McCracken, who

\footnotetext{
${ }^{18}$ Randy Henningson, "Upland Farmers and Agrarian Protest: Northwest Arkansas and the Brothers of Freedom" (unpublished master's thesis, University of Arkansas, 1973), 61. The counties primarily organized by the B of F in the Ozarks were Baxter, Boone, Madison, Marion, Newton, and Searcy counties. The B of F also organized a number of counties in the Arkansas River Valley of central-western Arkansas and in the Ouachita Mountains of the southwestern part of the state. The Agricultural Wheel, an initially separate "sister" organization founded the same year in the Arkansas Delta that was in "opposition to tyranny and monopoly, and for the maintainance [sic] of justice and right," organized several counties in the eastern Ozarks. On the Agricultural Wheel in Arkansas, see F. Clark Elkins, "Arkansas Farmers Organize for Action, 1882-1884," Arkansas Historical Quarterly 13 (Autumn 1954: 231-248; and F. Clark Elkins, "The Agricultural Wheel: County Politics and Consolidation, 1884-1885," Arkansas Historical Quarterly 29 (summer 1970): 152-175. The B of F eventually merged with the Wheel in 1885.
} 
helped establish several small and independent sawmills in the area, performed dental and some other medical work in his new community, and was elected a local justice of the peace by his native backcountry neighbors. By 1885 , McCracken's and other B of F organizers' calls to small farmers to unite and "stand beside each other in the right" had succeeded in enlisting between thirty and forty thousand members in western Arkansas. ${ }^{19}$

Initially, the B of F took great pains to avoid politicization and even "banned fractious political debate within its lodges." This was especially important in the Ozarks, where the organization hoped to stay out of partisan conflicts between Democrats, Mountain Republicans, and third-party advocates. Instead, the B of F championed a more unifying "self-help" strategy that encouraged its members to essentially boycott the increasingly commercialized farm and industrial economy by practicing "safety-first" agriculture and striving toward family selfsufficiency. The organization urged farmers to abandon most cash-crop production and their dealings with creditors. They were advised to replace these practices with more diversified general-farming techniques that prioritized growing food and other household and community necessities. To obtain supplies and items that they could not grow or make themselves, some local $\mathrm{B}$ of $\mathrm{F}$ lodges organized petitions that pressured area merchants to sign contracts pledging not to charge their members more than ten percent above wholesale costs. Many others attempted to circumvent merchants and creditors altogether by forming their own local cooperatives to purchase supplies in bulk at discounted rates and to help market salable crops at better prices than farmers might otherwise obtain individually. A number of local lodges also

\footnotetext{
${ }^{19}$ Henningson, "Upland Farmers and Agrarian Protest," 63, 79; Matthew Hild, "Brothers of Freedom," Encyclopedia of Arkansas History and Culture (http://www.encyclopediaofarkansas.net/encyclopedia/entrydetail.aspx? entryID=6990).
} 
adopted "resolution[s] to make this crop without going into debt." "By their own industry and hard licks," they hoped to break the chains of "debt and dependence." "We are a set of backwoodsmen out here on this mountain and do not know any better than to take each others [sic] advice, and to help each other in the right," declared a spokesman for one local B of F lodge. "Let the wire-pullers hold their wires and we the strings." 20

Most rural advocates for economic and political justice, however, soon realized that too much had changed in their region for small farm families to simply retreat and isolate themselves from rapidly modernizing American trends. After all, contrary to much popular myth, most rural Ozarkers were not anti-market or anti-modern. Their primary objection to recent economic developments was to the inequality produced by industrialization and capital-intensive agriculture and particularly to those prospering elites who controlled the increasingly unequal economy at small producers' expense. Rural Ozarkers' beef was not generally with the market economy itself. So the B of F's "self-help" program and call to to abstain as much as possible from market activities undoubtedly failed to appeal to small farmers as strongly as its architects had hoped. Even so, the B of $\mathrm{F}$ and its local cooperatives also quickly ran up against the tenacious and potentially undercutting economic and political power of those elites in the region who viewed their agenda as anathema to a "land of free traders." One Pope County lodge member finally grew so disillusioned with the impracticality of the B of F's self-help-only approach that he told fellow members that they had just as well "bay at the moon." After all, while small farmers attempted such passive resistance, the grip that greedy corporations and other self-serving elites had on government was growing stronger all the time, he argued. While

\footnotetext{
${ }^{20}$ Henningson, "Upland Farmers and Agrarian Protest," 74-80.
} 
farmers and other "common folks" shied away from political action, these wealthy elites were busy high-jacking government power to bolster their own privileges and to make "labor subservient to capital and monopolies." Rekindling a "spirit of justice" in government was urgent, insisted one leader of the farmers' movement in the region:

We have been keeping war hosses, lawyers, and wire-pullers in office long enough, and they are rather expensive stock, they cost more every year and do less...We are going to turn it all out, root hog or die, and get a new outfit. We don't care whether they are war hosses, mules or jackasses, so [long as] they fill the place with honesty, and act fair with the farmer.

It was high time that the "able and industrious people" started working toward "purifying" and taking back their government. After all, it was only fair that the "people's" government step up to provide "a little 'Protection' to put him [the laboring man] on equal footing," as one B of F member put it. ${ }^{21}$

By the late 1880 s, the B of F and other farmers' unions in the region merged their independent organizations with the larger Farmers' Alliance that was sweeping the broader rural South and Midwest. Urging a greater degree of unity among farmers across the region and with others throughout rural America, Alliance organizers in the Ozarks called on hill folks to help "suppress prejudices and unite the people as a band of brothers." In July 1892, a leader of the local Farmers' Alliance lodges in Searcy County, in the weekly "Alliance Column" printed in the local newspaper, pointed to the disaster of farmers' rising mortgages and indebtedness, which was accompanied by wealthy railroad magnates' and other corporate interests' stranglehold on

${ }^{21}$ Ibid., 75, 81-84, 98. 
government power. "Do you call this prosperity?" he asked. "What a free country! Let the plutocratic eagle scream from its lofty heights, let the night owl hoot and 'let the people be damned' is the verdict of the capitalists," he declared, urging fellow farmers to "grab the wheel and roll, all hands at once." In response to those "capitalists" who cried that the Alliance represented backwardness, anarchy, and "destruction," the Searcy County farmer-organizer retorted: 'If, 'On earth peace, and good will to man,' is destruction, we'll destroy. 'Equal rights to all, and special privileges to none,' is our pass word.",22

By 1890, an estimated 100,000 Arkansawyers had joined the national Farmers' Alliance. The national Alliance, which held its convention in St. Louis in 1889, put forth one of the most reform-spirited political agendas in American history, featuring calls for expansions of government power that might have been unimaginable only a few years before. Its list of political demands included the creation of progressive income taxes to be levied on the wealthy, a government takeover of transportation and communications industries, a liberal expansion of the national money supply through the free coinage of silver, strong regulations to curb absentee land ownership and speculation in agricultural real-estate, and a "Sub-Treasury Plan" in which the federal government would build and manage a network of warehouses where farmers could store commodities for collective marketing and obtain low-interest farm loans through the U.S. Treasury Department. The St. Louis platform also proposed direct elections for U.S. senate seats and endorsed an eight-hour workday for industrial laborers. Thousands of rural Ozarkers undoubtedly applauded the national farmers' movement's declaration that "We believe that the power of government — in other words, of the people — should be expanded... as rapidly and as

\footnotetext{
${ }^{22}$ W.O. Meek and T.M. Ferguson, “Alliance Column,” Marshall Mountain Wave, July 22, 1892.
} 
far as the good sense of an intelligent people and the teachings of experience shall justify, to the end that oppression, injustice, and poverty shall eventually cease in the land."23

The political insurgency of local and regional farmers' organizations in Arkansas made strong showings in local and state elections during the 1880s. Agrarian protestors mounted their biggest challenge to laissez-faire Democratic rule in the state in 1888 , when they forged a political alliance with Arkansas's small but growing class of industrial workers and the Knights of Labor. Christened the Union Labor Party and chaired by old B of F organizer Isaac McCracken, the agrarian political rebels and their industrial-laborer allies put forth a slate of candidates to contest the virtual political monopoly of Arkansas's conservative Democratic establishment. The state's small Republican Party, which, in addition to African Americans, owed much of its survival to rural mountain voters in certain sections of the western Ozarks, endorsed many of the Union Labor Party's political positions and candidates, including its gubernatorial nominee C.M. Norwood. Mountain Republicans in the Ozarks, much like other rural followers of the GOP "west of the Mississippi, where Republicanism remained a distinctly progressive faith," embraced the populist ethic and rejected the conservative economic principles held dear by Eastern capitalists who dominated the national party apparatus. The Union Labor Party's 1888 platform included demands for tight government regulations on rates charged by railroad companies, a state-enforced cap of six percent on the profits of private utility companies, a complete ban on non-resident land ownership in Arkansas, the abolition of convict labor and

\footnotetext{
${ }^{23}$ Elizabeth Sanders, Roots of Reform: Farmers, Workers, and the American State, 1877-1917 (Chicago: University of Chicago Press, 1999), 123, 131. The Alliance's St. Louis platform is reprinted in George B. Tindall, ed., $A$ Populist Reader: Selections from the Works of American Populist Leaders (New York: Harper Torchbooks, 1966), 76-77.
} 
mandatory, non-paid road work by citizens, tax reforms that especially supported public schools, and a law preventing companies from hiring private police to use against their workers. ${ }^{24}$

The 1888 Union Labor ticket came closer to unseating the Democratic Party's nearabsolute control of the state than any had since Reconstruction or than any would until the second half of the twentieth century. But it came up short. The September election was one of the ugliest and most blatantly undemocratic in Arkansas's political history, wrought with virulent race-baiting, fraud and intimidation at the polls, and even violence and assassination. The "official" election count indicated that Union Labor gubernatorial candidate Norwood had lost to the Democratic incumbent, eastern Arkansas planter and merchant James P. Eagle, by a mere 15,000 votes. Though Norwood and fellow farmer insurgents contested the election results, the Democratic-controlled legislature demanded that they pay $\$ 40,000$ to finance a recount, so that "the price of justice was too high for a Party comprised of poor farmers and workers." The Democratic establishment also embarked upon a ruthless legislative assault that granted their party near absolute control over local election precincts, imposed regulations on illiterate voters, and enacted a poll tax, all in the name of "election reform." These measures stymied any future attempts to forge another politically viable working-class opposition party. ${ }^{25}$

\footnotetext{
${ }^{24}$ Dougan, Arkansas Odyssey, 303-304; Jeannie M. Whayne, "Prosperity Eluded," 266-267. For an excellent case study of political violence and assassination, see Kenneth C. Barnes, Who Killed John Clayton? Political Violence and the Emergence of the New South, 1861-1893 (Durham: Duke University Press, 1998). For a more detailed treatment of Arkansas Republicans' efforts to "fuse" with agrarian populists, see Joe T. Seagraves, "Arkansas Politics, 1874-1918" (unpublished PhD dissertation, University of Kentucky, 1973), 179-181, 248. Quotation on western Republicanism as a "distinctly progressive faith" is taken from Kazin, A Godly Hero, 251. Also, for an example of defiance by many "progressive" western Republicans, including Arkansas's, against the national party establishment, see "Silver Republicans," Clinton Democrat, June 10, 1897.

${ }^{25}$ Dougan, Arkansas Odyssey, 304; Whayne, "Prosperity Eluded," 266-268. After squeaking by in 1888, alarmed conservative Democrats quickly went to work on schemes to bat down similar political challenges in the future by passing "election reform" laws. In 1891, conservatives passed legislation that granted the Democratic Party nearly exclusive control over the appointment of local and state election officials and effectively barred illiterates from
} 
Some Arkansas historians have pointed to 1888 as the "high-water mark...for political insurgency" in the state, but, just as the far less numerous Mountain Republicans had tried to coopt agrarian defiance, the popular rural revolt galvanized a growing economic Left of the Democratic Party to overthrow the old conservative gospel of laissez-faire, in word if not always in deed. ${ }^{26}$ To the chagrin of many wealthy planters and corporate interests, Democrats sympathetic to the agrarian cause worked to absorb populist sentiments and muscled their way into the party's power structure. They finally discovered their leader in the rambunctious and adept orator and politician Jeff Davis of Pope County. "Populists—why, I used to hate them," Davis once remarked in a campaign speech, "but I did not know as much then as I do now; I did not have as much sense then as I have now." 27

The ambitious Davis first erected the sail of his soon-to-be historical political career into the ferocious winds of rural populism in 1899, when, as the state attorney general, he embarked upon a merciless war against insurance companies and other corporations by loosely interpreting Arkansas's existing anti-trust laws. Davis declared that his prosecutorial efforts represented "the first stroke in the great battle of the masses against the classes." "My God, if there ever was a cold-blooded, arrogant, high-handed, obstreperous, hard-to-down trust it is the insurance business," Davis quipped. When the conservative Arkansas Supreme Court — those "five jackasses" in Little Rock, as Davis called them—overruled him and virtually wiped out a year's

voting in Arkansas. Voter turnout dropped by nearly 20 percent between 1890 and 1892. Then, in 1892, a poll tax was instituted, which "particularly effected poor farmers"-black and white. Historians and political scientists have estimated that the poll tax disfranchised another 15 percent of blacks and between 9 and 12 percent of poor whites in Arkansas. Dougan, Arkansas Odyssey, 304; Whayne, "Prosperity Eluded," 266-269. According to political scientist Jay Barth, the Democratic political establishment had "emasculated the opposition and forced the emerging populist temper to participate within a one-party and generally issueless mold for the next six decades." Jay Barth, "Democratic Party," Encyclopedia of Arkansas History and Culture (http://www.encyclopediaofarkansas.net/encyclopedia/entry-detail.aspx?entryID=593).

${ }^{26}$ Dougan, Arkansas Odyssey, 305.

${ }^{27}$ Davis quoted in Arsenault, Wild Ass of the Ozarks, 218. 
worth of his office's work, his image as a populist defender of the meek working man and emergence as a "hillbilly folk hero" reached new heights. "Styling himself a martyr," Davis promised rural Arkansas voters in his first gubernatorial campaign that "if I win this race I have got to win it from every railroad, every bank and two-thirds of the lawyers and most of the big politicians. But if I can get the plain people of the country to help me, God bless you, we will clean the thing out." After scoring the "most resounding political victory in Arkansas history" in 1900, Davis, despite stiff resistance from political opponents, went on to achieve some important populist-progressive reforms during his three terms as governor, namely some stronger anti-trust legislation and much-needed changes to the state's prison system. ${ }^{28}$

Once in office, however, Davis demonstrated that his abilities on the campaign stump far exceeded his statesmanship. Indeed, much more than any meaningful policy changes, one of the greatest legacies of Davis's remarkable career was his construction of a powerful political coalition that, notwithstanding his radical rhetoric, by and large transcended class, the rift between town and country, and even the historically pronounced divide between Arkansas's lowlands and uplands. His new coalition machine "brought him added power and security, but it also compromised the ideological integrity of the Davis movement" because many of his political allies "had little sympathy for and little understanding of the revolt that had brought Davis to power." "He was an innovative politician who knew how to acquire and hold power," writes his most prominent biographer, "yet his administration produced more politics than government, more rhetoric than reform." ${ }^{29}$ An archetype of nebulous populism, Davis once

\footnotetext{
${ }^{28}$ Dougan, Arkansas Odyssey, 309; Raymond O. Arsenault, "Jeff Davis, 1901-1907," in The Governors of Arkansas: Essays in Political Biography, edited by Timothy P. Donovan, et al., (Fayetteville: University of Arkansas Press, 1995), 118-130; Arsenault, "Jeff Davis (1862-1913)," Encyclopedia of Arkansas.

${ }^{29}$ Arsenault, "Jeff Davis, 1901-1907," 123, 130.
} 
contended that the "old Populist Party advocated some of the grandest doctrines the world ever new" with its proposal for a government-takeover of the railroad industry and other "public franchises," and he declared that "you can legislate prosperity into a country if you have the right kind of men to do the legislating." Davis, nevertheless, effected practically no structural change during his long political career. ${ }^{30}$

Despite his often rowdy and threatening rhetoric, Davis governed in a way that ultimately proved acceptable to those invested in the status quo. He continued to appeal to large numbers of the dispossessed in the backcountry, however, because he skillfully succeeded in tapping rural sentiments and attitudes. Davis masterfully portrayed himself as one of them: a humble underdog fighting valiantly in an unfair fight against the abusive powers that be. Like an earlytwentieth-century Ozarks version of David battling Goliath, Davis vowed to "let the scavengers of plutocracy howl!" and promised his rural constituents that, "insignificant as I am, if my political career be marked, let them sharpen their blade, for I will be here at the appointed hour, and while here only God can stay my voice in behalf of organized, united labor and the yeomanry of America." ${ }^{31}$

One of Davis's most successful tactics for building and holding together his broad and fragile political coalition was his exploitation of the racial fears of rural and town-dwelling whites of all classes. Davis once boasted that he had "told the boys around Morrilton, Russellville and Plumerville, that if they elected me, I would fill the penitentiary so full of niggers their feet would be sticking out of the windows." As governor, though ultimately

\footnotetext{
${ }^{30}$ Davis quoted in Arsenault, Wild Ass of the Ozarks, 218.

${ }^{31}$ Davis quoted in ibid., 167.
} 
unsuccessful, Davis proposed a bill that would have racially segregated Arkansas tax revenues earmarked for schools, arguing that "every time you educate a 'nigger' you spoil a good field hand." Davis's race-baiting rhetoric rivaled that of any of the staunchest southern white supremacists of his time. "We may have a lot of dead niggers in Arkansas, but we shall never have negro equality," he once bellowed in a speech, "and I want to say that I would rather tear, screaming from her mother's arms, my little daughter and bury her alive than to see her arm in arm with the best nigger on earth." Davis even made national headlines in 1905 when, in giving the opening remarks before a crowd of 40,000 people to welcome President Theodore Roosevelt to Little Rock, he openly defended the practice of lynching, prompting the president to scold the Arkansas governor when he took the stage. And to top off his racist political agenda, Davis led the charge for the adoption of mandatory whites-only primary elections by Arkansas's Democratic Party in 1906, vowing that "'nigger' dominion will never prevail in this beautiful Southland of ours, as long as shotguns and rifles lie around loose, and we are able to pull the trigger., 32

Rabid hillbilly racism, much like presumably anti-furriner sentiments, has long figured prominently in stereotypical accounts and imagery of rural mountain isolation and cultural backwardness. Rural racism in the Ozarks, though, as virulent and nasty as it often was, can hardly be interpreted as anything "exceptional" in late-nineteenth- and early-twentieth-century America. Moreover, while racial fear-which at times led to horrific white-on-black violence and racial "cleansing" - pervaded the Ozarks during the era, it did not typically trump anti-elitist sentiments in the rural backcountry. In fact, racial conflict often blended with rural whites'

\footnotetext{
${ }^{32}$ Davis quoted in Dougan, Arkansas Odyssey, 311; and Arsenault, Wild Ass of the Ozarks, 205-206, 211-213, 214.
} 
populist antipathy for wealthy and privileged elites, just as it frequently did in urban workingclass communities across America. Hill people tended to connect the in-migration of blacks into the region during the late nineteenth and early twentieth centuries with industrialization's alarming social changes, growing economic inequalities, and rural dispossession. In 1894, white working-class vigilantes in Black Rock in western Lawrence County, for instance, protested against low wages and the increasingly imbalanced economic control of the area's lumber industries by first vowing to expel employers' new "cheap" black laborers from the community and then by threatening to destroy company property. Similarly, local working-class whites in the radical agrarian stronghold of Polk County in the Ouachita Mountains, who were also joined by some Eastern European immigrants who had recently arrived to the area, kicked up in 1896 when the Kansas City, Pittsburgh and Gulf Railroad Company imported thirty black laborers to help construct its new railway through the county, sparking a violent standoff between local industrial boosters and working-class whites. ${ }^{33}$ Skillful politicians like Jeff Davis, then, frequently succeeded in deploying race to undercut a potentially greater populist union of a rural working-class economic Left that might have otherwise broken the established party's fragile political coalitions between town and country, local elites and common backcountry folks, and the lowlands and uplands.

\footnotetext{
${ }^{33}$ On the 1894 racial conflict in Black Rock, see Blake Perkins, "Race Relations in Western Lawrence County, Arkansas," Big Muddy: A Journal of the Mississippi River Valley 9.1 (2009): 7-14. On Polk County, see Guy Lancaster, "There Are Not Many Colored People Here': African Americans in Polk County, Arkansas, 1896-1937," Arkansas Historical Quarterly 70 (Winter 2011): 429-449. Importantly, the vast majority of racial conflicts in the Ozarks occurred in industrializing areas. See Kimberly Harper, White Man's Heaven: The Lynching and Expulsion of Blacks in the Southern Ozarks, 1894-1909 (Fayetteville: University of Arkansas Press, 2012). While rural whites in those few backcountry agricultural communities with African American populations certainly expected their black neighbors to adhere to traditional racial mores, there generally tended to be greater "racial harmony and [a] relatively relaxed atmosphere in which blacks and whites commingled daily" in less competitive small farm communities in the Ozarks. Brooks Blevins, "Revisiting Race Relations in an Upland South Community: LaCrosse, Arkansas," in History and Hope in the Heart of Dixie: Scholarship, Activism, and Wayne Flint in the Modern South, edited by Gordon E. Harvey, et al., (Tuscaloosa: University of Alabama Press, 2006), 18. Also see Perkins, "Race Relations in Western Lawrence County," 14-18.
} 
Racial animosity, however, did not inevitably obstruct a class-based rural populism in the region. While many populist farmers' organizations sought to avoid race or outright barred black membership, evidence suggests that in cases when agrarian-populist leaders and organizers made the decision to take up the issue of race and deliberately attempted to convince small white farmers that poor blacks were experiencing the same struggles against elite capitalist oppressors that they were, they could have some success in overcoming staunch racial divisions, even if only for political reasons. Arkansas's significantly disfranchised People's Party in the early 1890s openly championed major government-instituted reforms to bring economic justice to "the downtrodden regardless of race," a political stance that one prominent historian refers to as the South's "clearest record of racial liberalism." The early-twentieth-century agrarian radical Sam Faubus of Madison County, furthermore, came around to believing that "if the powerful could keep down one group such as blacks...then the powerful could keep down another group such as poor hillside farmers." Historian James M. Beeby has convincingly shown that it "is striking how racism often circumscribed the limits of Populist dissent and prevented unity along class lines." But he says "it is also clear that African Americans and whites often did come together, however briefly and despite mutual suspicion, to espouse and, in some cases, enact significant economic and political change." "The Populists," writes Beeby, "were a product of their time, but...[they] sought to reorient southern society in a more progressive way, both politically and economically."34

\footnotetext{
${ }^{34}$ Arkansas's Populist Party and historian Lawrence Goodwyn are quoted in Sanders, Roots of Reform, 129. On Sam Faubus, see Tom Wagy, "Little Sam Faubus: Hillbilly Socialist," Arkansas Historical Quarterly 53 (Autumn 1994): 275. Beeby quotations from James M. Beeby, "Introduction: Populism in the American South," in Populism in the South Revisited: New Interpretations and New Departures, edited by James M. Beeby (Jackson: University Press of Mississippi, 2012), xvii.
} 
Along with race, Jeff Davis and his Democratic machine also utilized intentionally vague rhetoric and often took squishy and largely issueless political positions that could easily appeal to both the region's powerful New South elites and poor backcountry folks alike, though for very different reasons. Railing against the federal government's adherence to the gold standard and lampooning giant monopolies in the Northeast proved effective for scoring points with both the plain folks in the backcountry and the region's well-bred elites. The William Jennings Bryansupporting but also local industry-boosting editor of the Mountain Wave in Searcy County, for instance, complained in October 1898 that "the majority of farmers and laborers throughout the country have less ready money and are living harder now than ever before - thanks to the iniquitous gold standard and the trusts." Gold-loving politicians in the East, such as William McKinley, could also make for easy targets that could command general agreement in the region: "The god of the republican party is gold," touted the same editor about a year earlier in 1897..$^{35}$

Many New South elites in the Ozarks eventually even came around to embrace the radical populist demand to have the government nationalize railroads and other utility industries, but mainly because they believed economic development in their region had been slighted by the private companies. In March 1899, the business-minded editor of Pope County's CourierDemocrat professed that he and other local leaders had come to "unequivocally favor" the public ownership of railroads and other utilities, insisting that "we are almost out of breath trying to catch up and climb into the band-wagon." Similarly the editor of Searcy County's newspaper complained in October 1897 about "Mr. Morgan's railroad scheme" and explained that "we have

\footnotetext{
${ }^{35}$ Mountain Wave, October 14, 1898 and October 8, 1897.
} 
been slow to believe that government ownership of railroads would be best for this country, but that would be infinitely more preferable." ${ }^{36}$

A number of local elites, moreover, began to take new pains to rebut accusations by traditional economic conservatives who charged that "populism" represented a heretical slap in the face to Thomas Jefferson's founding vision of America. The Courier-Democrat editor printed an article in April 1901 praising the recent remarks made by New York senator David B. Hill to the Jefferson Club in Buffalo. Hill, the article reported, rebuffed conservative Jeffersonian disciples of "limited government" by pointing to the venerated president's own "extension of American institutions," namely the Louisiana Purchase of 1803. Though sure to note that "true" Jeffersonian ideology "stands against radicalism of every description" and is "opposed to plutocracy on the one hand and to communism on the other," Hill insisted that the founding father would have certainly advocated extensions of government power that promoted "democratic expansion." "Jefferson's teachings might suggest a limitation upon the amount of dividends which could be lawfully declared," for instance, "or upon the profits which could be legally accumulated by these tremendous business organizations." "When billion dollar corporation combines are forming on every side... it is high time to consider whether some wholesome restrictions upon such corporate undertakings are not essential in the interest of the people." Similarly, an editorial in Searcy County's Mountain Wave compared populist Democrat and presidential contender William Jennings Bryan to "Thomas Jefferson, the great founder of democracy." It praised comments made by Bryan in a recent Labor Day speech in St. Louis, particularly his assertion that "not only must any prosperity begin with those who toil, but the

\footnotetext{
36 "Public Ownership of Railroads," Russellville Courier-Democrat, March 2, 1899; "Morgan's Railroad," Mountain Wave, October 8, 1897.
} 
Nation's progress toward a higher civilization must be measured by the progress made by the producing classes. It is the average progress, not the progress of the few, that must always be considered.",37

Beneath the defiant and reform-demanding political rhetoric, though, Ozarks elites' "populist" vision usually differed significantly from that of increasingly dispossessed backcountry folks in their locales, if the editorial positions of most county-seat newspapers in the region are any indication. While his paper was prone to scoff at the country's dominance by powerful Northeastern monopolies, the "populist"-professing editor of the Sharp County Record praised in 1890 the fact that "millions of northern capital are flowing into the southern states for permanent investments." Ironically, the article was printed below a celebratory advertisement about a new edition of a popular book on the recent history of the agrarian political movement. Likewise, the editor of Yellville's Mountain Echo in Marion County bragged in 1898 that he had just sold the mineral rights to more than eight-hundred acres of hill land at a great profit and encouraged his local readers to take notice of the potential for the area's economic growth because "the woods are getting full of men wanting to make investments.",38

The evolving editorial positions of Searcy County's Mountain Wave on the politics of railroads between September 1897 and September 1899 also reveal the particularly commercial, development-oriented New South agenda of local elites' brand of the "populist persuasion." In September 1897, the editor excitedly reported on the hopeful "prospects" that the Frisco Railroad and a couple of other companies might be planning to construct tracks through Searcy County.

\footnotetext{
37 "Not Born to Die," Russellville Courier-Democrat, April 18, 1901; Mountain Wave, October 1, 1897.

38 “Capital Coming South," Sharp County Record, January 23, 1890; Editorial from Yellville Mountain Echo reprinted in the Courier-Democrat, November 17, 1898.
} 
"No matter what road builds into North Arkansas," he wrote, "others will be forced to follow, and whichever company does the forcing act should and will have the everlasting gratitude of the people of this country." Only a few weeks later when company plans apparently fell through, the disappointed and likely angry Wave belatedly endorsed the populist call for publicly-owned railroads, stating that now "we see no way out of it but for the State to own the railroads." Meanwhile, however, since the the nation's and state's current conservative political leadership probably meant in reality that "there is no longer hope" for a publicly-owned railroad project in the area, at least in the foreseeable future, the Wave's editor encouraged the region's political leaders to "turn their attention to some other practical schemes to secure an outlet for our immense natural wealth." Namely, he called for a government-funded "internal improvement" project to widen and deepen the Buffalo River so that it could be connected commercially to the larger and navigable White River. The Wave also demanded government improvements and new construction of overland roads in the region. ${ }^{39}$

But the Wave never gave up on the promise of what an iron horse might mean for the future "prosperity" of the county and region. Pointing to the "inter-montane" area in and around Wiley's Cove in Searcy County, particularly its agricultural potential and rich mineral and timber resources, one local Ozarks booster insisted that political leaders in Little Rock "should become thoroughly acquainted" with the striking similarities of this currently "undeveloped" mountainous area to that of the booming Appalachian city of Asheville, North Carolina. "Arkansas is to have here a most important mountain city," he envisioned, "...once the country has become accessible by means of railroads.” Alas, in 1899 the North Arkansas Railroad

\footnotetext{
39 “Will it Reach Us?” Mountain Wave, September 24, 1897; “Margan's Railroad," ibid., Oct. 8, 1897; "The Buffalo Navigable," ibid., November 5, 1897.
} 
Company revealed definite plans to construct tracks through and erect depots in Searcy County. Apparently having abandoned his former position on government-owned railroads, the Wave's editor now became an ardent booster for the company and even began heading up a drive to raise a "bonus of $\$ 7,000$ " from local citizens to provide the railroad company with some extra incentive. By September 1899, he was running a weekly column titled "Is Your Name Here? If Not, Why Not?" in which he listed the names and amounts donated for the "North Arkansas Railroad bonus," urging citizen-minded locals to contribute to the future economic progress and common good of the area. ${ }^{40}$

For many backcountry Ozarkers, however, the late-nineteenth- and early-twentiethcentury "populist ethic" invoked very different ideas and visions. While some undoubtedly supported the "development" plans of regional elites, many others viewed the realities of New South boosters' visions of capitalist industrialization and increasingly commercialized agriculture as antithetical to their goals of sustaining and reproducing smallholder, family-farm life in the rural Ozarks. Indeed, while most backcountry folks seconded local elites' complaints against Northern and Eastern monopolies and their favoritism in most government policymaking, many detested just as much, if not more so, the well-to-do local elites who disproportionately wielded political and economic control within the Ozarks. Sharp County farmers' movement organizer and future Populist Party gubernatorial candidate W.S. Morgan noted this more radical potential of the malleable "populist persuasion" among the rural folks he worked with and encountered:

\footnotetext{
${ }^{40}$ M.L. DeMalher, "Inter-Montane Arkansas," ibid., October 7, 1898; "Is Your Name Here? If Not, Why Not?" ibid., September 16, 1899.
} 
...many persons seemed to conceive the idea that it was an instantaneous cure-all for every evil which inflicts humanity...Some of them had an impression that...[it] had a mission to redress a specific private grievance. Some thought that the paramount object was to wage hostile war upon the one-horse country merchants, and hailed it with delight as the means by which said merchants were to be driven out of business. Others who had been swindled by commission men, conceived the idea that its special mission was to displace this class of tradesmen. Still others, who were riding some political hobby, thought they saw their opportunity...for airing their views, and, possibly, riding into some lucrative office on this promising young steed. Many others had a vague idea that something was going to happen. They did not know exactly what, or how, but saw there was a great popular uprising which would revolutionize things... ${ }^{41}$

Tucked beneath the broad and malleable populist ethos that managed to appeal to practically all stripes in the Ozarks were intense conflicts within the region between rural debtors and their wealthier merchant-creditors, town-dwellers and their social and economic interests and country folks and theirs, and the agendas of larger prosperous farmers and those of poor-tomiddling smallholders. Some of the more dramatic and tragic conflicts made the local news. In November 1897, for instance, the Pope County newspaper briefly reported on a bloody altercation between a local merchant and a farmer who "became involved in a difficulty about a settlement." Claiming he acted in "self-defense," the merchant "drew his pistol and shot at [the farmer] five times, two bullets taking effect, one piercing each lung." In the same column of the

\footnotetext{
${ }^{41}$ W.S. Morgan, History of the Wheel and Alliance and the Impending Revolution (Fort Scott, KS: J.H. Rice and Sons, 1889), 148-149.
} 
same issue, the newspaper also reported that a few days earlier "some unknown person placed a stick of dynamite underneath a rail" on the railroad tracks in the area, "but it was fortunately discovered and removed a few minutes before a passenger train was due at that point." In another probable example of particularly violent conflict between the local haves and have-nots in the region, some unknown "incendiaries" in Carroll County torched "the general store of J.N. Cardwell \& Son," on the first day of February in 1899, causing the merchant a "loss [of] about $\$ 10,000$ and not a cent of insurance. ${ }^{42}$

Of course, despite stereotypical mountain imagery to the contrary, most rifts between backcountry folks and local elites did not end so violently and sensationally. Still, the potential for and reality of rural defiance against prominent members of local establishments in the Ozarks was widespread, and regional elites revealed their alarm in their attempts to keep a lid on such radical expressions of populist resistance. The editor of Searcy County's Mountain Wave, for example, in an article in October 1897 titled "Democracy is Law," cited the recent condemnation of radical resistance by one of many rural Ozarkers' greatest national political heroes, the godly populist Democrat William Jennings Bryan, who warned that "those who have suggested that the burning of property and the destruction of life as a means of settling labor disputes do not understand the genius of our institutions." The Wave editor took the opportunity to extrapolate for his local readers. Omitting any mention of Arkansas's recent "election reform" laws that had effectively disfranchised a large number of the region's poorest rural voters, the editor lectured that "the ballot is in the hand of every American citizen above the age of 21 years. He can use it

\footnotetext{
42 "Merchant Shoots a Farmer," Russellville Democrat, November 11, 1897; "Put Dynamite Under the Rail," ibid., November 11, 1897; Courier-Democrat, February 9, 1899.
} 
to correct every abuse of power and every injustice imposed by the strong upon the weak." He continued:

There is no anarchy in Democracy. There is nothing in its traditions or in its creed which councils [sic] violence for the correction of public or private wrongs. There is nothing but equal justice and good order in Democracy, and those who interpret its character in any other way do not understand the genius of the party of Jefferson and Jackson. ${ }^{43}$

The editor of the populist-leaning, pro-Bryan Courier-Democrat in Pope County also seemed to worry about excessive populism creeping into the established political channels. In July 1901 he reprinted some comments, which he apparently agreed with, made by former Missouri governor W.J. Stone, who had recently warned about the dangers of trusting the more rambunctious agrarian political leaders with too many leadership positions in the Democratic Party, particularly those who had "deserted their party in 1896, 1898 and 1900" to support thirdparty Populist candidates. "I am not opposed to the return of the prodigals, and in fact I am anxious to have them return," said Stone. "As Mr. Bryan said, I would be willing to barbecue the fatted calf when they do return," he continued, "but I would not be willing to make them a deed to the farm and I would want them to help the old hands raise one crop at least before making them the overseers." The agrarian-populist revolt had shifted the Democratic Party in Arkansas away from its old conservative laissez-faire ideological purity, much like it had done to

43 “Democracy is Law," Mountain Wave, October 1, 1897. 
its national counterpart, but many of the party's more well-to-do and elite supporters clearly worried about the more radical potential that the populist ethic had stirred at the grassroots. ${ }^{44}$

By the 1910s, despite his inability to accomplish much meaningful reform, many rural Ozarkers continued to cast their votes for Jeff Davis and the populist-sounding allies of his Democratic coalition, confident that they were doing the best they could for the common folks against nearly impossible odds. Davis's shrinking margins of electoral victory and the gradual crumbling of his political machine, however, may indicate that a number of other rural voters began to grow impatient with too much talk and not enough "populist" action. ${ }^{45}$ A sizeable minority of rural backcountry Ozarkers, in fact, began organizing and joining new local chapters of the Socialist Party during the first decade of the 1900s, asking "By what rule of truth, right or justice has any other person a right to labor's production?" These backcountry political radicals contended that "The laboring people will never be satisfied with anything less that [sic] all of the wealth they produce. Socialists maintain that labor's share to the wealth he produces is all." In fact, drawing on a conceptual combination of "republican ideals expressed in the Declaration of Independence, the moral teachings of Jesus Christ, and the political theories of Karl Marx," these "hillbilly socialists" made a number of backcountry communities in the Arkansas Ozarks, along with their rural Oklahoma neighbors to the west, hotbeds for one of "the most vigorous, ambitious, and fascinating" movements of political radicalism in American history. ${ }^{46}$

\footnotetext{
44 "Stone Discusses Reorganization," Courier-Democrat, July 25, 1901.

${ }^{45}$ On Davis's declining margins of victory at the polls in his later elections and the depreciating power of his political machine, see Arsenault, "Jeff Davis, 1901-1907," 117-130.

${ }^{46}$ G. Gregory Kiser, "The Socialist Party in Arkansas, 1900-1912,” Arkansas Historical Quarterly 40 (Summer 1981): 119-153, quotations on 121; Jim Bissett, Agrarian Socialism in America: Marx, Jefferson, and Jesus in the Oklahoma Countryside, 1904-1920 (Norman: University of Oklahoma Press, 1999), quotation on 8 . Also see James
} 
Many other rural Ozarkers took their populist sensibilities in a less insurgent and typically less partisan direction. Beginning in 1906, local chapters of the Farmers' Union (Farmers' Educational and Cooperative Union of America) - probably the closest heirs to the late-nineteenth-century agrarian farmers' organizations - formed throughout the region to press for more issue-specific reforms. The local chapters of the Farmers' Union lobbied for and endorsed candidates—Democrats, Republicans, or Socialists—who would support more equitable and progressive taxation, expansions of public and agricultural education, and various forms of government protection and assistance for common farmers and other rural folks. Arkansas's new and rising cadre of "Progressives" in the Democratic Party, in fact, who determined to expand the role of government to "improve" the lives of the citizenry, began to diligently court the votes of the organization's rural members, since, as one member put it, they "very much needed most of the Farmers Union vote" to defeat the Old Guard and remnants of the Davis machine. Knowing that the "union represented a potentially huge bloc of voters" and that "it had more members than any other organized interest group in the state," George W. Donaghey, who would be elected as Arkansas's first "Progressive" governor in 1908, even gave the "welcome address" at the Farmers' Union's annual state convention in $1907 .{ }^{47}$

However rural Ozarkers decided to cast their votes during the early twentieth centurythat is, those who could afford to pay their poll taxes and were not too illiterate to vote after "election reforms" were imposed in the early 1890s — it was clear that their sensibilities about

R. Green, Grass-Roots Socialism: Radical Movements in the Southwest, 1895-1943 (Baton Rouge: Louisiana State University Press, 1978).

${ }^{47}$ William E. Halbrook, "A Review of My Membership in the Farmers Union," Arkansas Historical Quarterly 15 (Autumn 1956): 202-208; Kiser, "The Socialist Party in Arkansas," 139-140; James F. Willis, Southern Arkansas University: The Mulerider School's Centennial History, 1909-2009 (Magnolia, AR: Southern Arkansas University Foundation, 2009), 26. 
government were shaped by the populist ethic that had been aroused at the grassroots during the last two decades of the nineteenth century. These were not the hardshell anti-government mountaineers simplistically depicted in much of Ozarks legend and lore. In this Gilded Age of concentrating wealth, growing social inequalities, and rural dispossession, most rural Ozarkers demanded a good "cleaning out" of government offices and institutions and a "restoration" of the principle of "people's rule" in America, a principle they believed had been corrupted by the rich and powerful.

Backcountry populists insisted that the "people's republic" should flex its muscles in new and unprecedented ways to protect the commoners against their greedy oppressors. "It was a vision informed by historical experience - by the structure and dynamic of the family farm, the shop, and the local market; by notions of government as the repository of the public will and the defender of the public good — and tailored to the exigencies of an expansive society," explains historian Steven Hahn. ${ }^{48}$ While the general populist ethos proved flexible enough to forge a rather unspecific and vague consensus of anti-establishmentarianism in the region, populism aroused strands of radical resistance at the grassroots, particularly in the backcountry, that often turned its indictments upon well-to-do Ozarkers and local structures of authority that disproportionately commanded economic and political power in the region as much as it did upon "outsider" oppressors. It would be this dynamic of local conflict within the Ozarks, more so than some culturally engrained antipathy of government authority passed down in rural isolation by the region's earliest settlers, that shaped the better part of backcountry hill folks'

\footnotetext{
${ }^{48}$ Hahn, The Roots of Southern Populism, 283.
} 
sensibilities as they resisted their "first tastes" of the emerging American state's "reform" powers during the first half of the twentieth century. 


\section{Chapter Three}

\section{First Tastes}

In the late summer of September 1897, the New York Times and several newspapers throughout Arkansas reported on the tragic killing of two U.S. deputy marshals by moonshiners deep in the rugged Ozarks. Determined to quash illicit distilling in this mountainous area which, according to the New York Times, had "for many years been a favorite rendezvous for moonshiners and counterfeiters," marshals B. F. Taylor and Joe Dodson led a small raiding party into northeastern Pope County, a place described by Little Rock's Arkansas Gazette as “one of the wildest regions imaginable...remote from the centers of civilization," where "Desperate Mountaineers" always stood ready "to resist the invading arm of the law." As the marshals came within thirty yards of "one of the largest stills in the mountains," they "walked into an ambush, and the unerring aim of the lawless mountaineers...made short work of them." The torrents of gunfire killed Taylor and Dodson on the spot and wounded two other possemen before the unseen moonshiners escaped from the scene. ${ }^{1}$

In the ensuing days, authorities and the Taylor family offered a combined reward of $\$ 1,000$ for the capture and conviction of the guilty parties, and federal, state, and local lawmen worked diligently to apprehend the suspects. More than a year later, officials finally apprehended their key suspect, the "somewhat notorious" moonshiner and farmer Harve Bruce of Van Buren County. Bruce, who was also a Confederate veteran and former deputy sheriff, at first "emphatically denie[d] his guilt" but later admitted to killing the marshals, claiming that he

\footnotetext{
1 “Ambushed by Moonshiners," New York Times, August 31, 1897; “Two Killed,” Arkansas Gazette, August 31 , 1897; “A Horrendous Crime,” Russellville Democrat, September 2, 1897.
} 
was the only one at the still who fired his weapon at the lawmen. But he insisted that he had done so in self-defense, fearing that his life was at stake, and had returned fire only after the raiding possemen — who he claimed had not identified themselves as authorities—shot first. A Pope County jury convicted Bruce of involuntary manslaughter, and he served a short prison sentence before Arkansas governor Jeff Davis — whose private law firm had helped defend the moonshiner during his trial—-pardoned him. ${ }^{2}$

In the popular imagination, such widely-publicized scuffles between mountain moonshiners and federal lawmen in the Ozarks and Appalachia seemed to illuminate an exceptional rural hill culture of unbending anti-government attitudes - a cultural ethos assumed to have remained stagnant and unchanged in mountain isolation and unmovable tradition since the first pioneer settlers of the early nineteenth century. These tales of stubborn and doggedly independent backwoods moonshiners resisting the feds have probably contributed more than anything to shaping assumptions about an inherently authority-defying mountain culture. As historians, sociologists, and other scholars of the mountain South have shown, however, the perpetuation of such imagined cultural imagery and stereotypes tends to tell us much more about those who narrate the stories than the actual experiences and feelings of the hill folks themselves. $^{3}$

\footnotetext{
2 “A Big Reward," Russellville Democrat, October 28, 1897; "Got Harve Bruce," Courier-Democrat (Russellville), October 7, 1898; Courier-Democrat, November 16, 1899; "Involuntary Manslaughter," Courier-Democrat, November 23, 1899.

${ }^{3}$ See, for instance, Henry D. Shapiro, Appalachia on Our Mind: The Southern Mountains and Mountaineers in the American Consciousness (Chapel Hill: University of North Carolina Press, 1978); Allen W. Batteau, The Invention of Appalachia (Tucson: University of Arizona Press, 1990); Brooks Blevins, Arkansas/Arkansaw: How Bear Hunters, Hillbillies, and Good Ol' Boys Defined a State (Fayetteville: University of Arkansas Press, 2009); and Brooks Blevins, Hill Folks: A History of Arkansas Ozarkers and Their Image (Chapel Hill: University of North Carolina Press, 2002).
} 
Probing beneath the myths and stereotypes that have shrouded the violent 1897 affair in Pope County reveals that the practical necessities and burdens of an increasingly commercialand agribusiness-oriented rural economy and society had much more to do with Bruce's and his fellow moonshiner-farmers' resistance than some unique anti-government mountain culture. Rural Ozarkers like Bruce, who made moonshine, resisted government regulations and law enforcement because they felt unjustly prohibited from pursuing an agricultural and entrepreneurial pursuit that held the best promise for sustaining their way of life and prospering as family farmers in increasingly opportunity-strapped hill communities. As was the case for distillers plying their trade in the Great Smoky Mountains, "the story of moonshine," according to historian Daniel S. Pierce, "is a story of how people of little, and often worsening, means tried to find ways to cope with the difficulties of life."4

Contrary to the dominant perception of the mountain moonshine wars as primarily clashes between parochial rural denizens and government outsiders_-or "furriners"—intruding into local affairs with their distant bureaucratic agendas, the violent altercation in Pope County more precisely reflects the conflict and struggles for power and freedom between locals within the region amid the uneven development of American capitalist transformation. In particular, it illuminates the competing social and economic interests that frequently divided the region's supporters of the New South's industrial and agri-business oriented political economy and struggling small-farm families who seemed to more and more find themselves with the rawest end of the deal.

\footnotetext{
${ }^{4}$ Daniel S. Pierce, Corn From a Jar: Moonshining in the Great Smoky Mountains (Gatlinburg, TN: Great Smoky Mountains Association, 2013), 8.
} 
Bruce's and other moonshiners' defiance in the Ozarks is best understood when viewed in the context of the more radical strands of rural resistance unleashed in a number of backcountry folks amid the broader and variegated populist ethos that swept the region during the late nineteenth and early twentieth centuries. No conservative defenders of smallgovernment ideological purity, rural and small-town Ozarkers-poor farmers and laborers, wellto-do landowners and businessmen, Democrats, Republicans, and third-party supporters alikecalled for a pragmatic government to exert its power on behalf of "the people" and against “special interests." This general populist political culture, however, held different meanings for different folks in the Ozarks, as it often did elsewhere throughout rural America. Well-bred and prosperous farmers and businessmen in the Ozarks tended to view Big Capital in the American North and East as the primary obstacle standing in the way of their vision of "people's justice," which they believed could be best fulfilled by redistributing and growing New South capitalism in the region. But struggling and dispossessed small farmers like Bruce and his fellow moonshiners - while they too were at times prone to scoff at Eastern bankers and business trusts - also resented how the privileged elites within the region primarily influenced, controlled, and administered the arms of government power to further their own economic and social agendas. While they hoped and waited for their vision of a strong, well-regulated, and "true" populist republic to be fulfilled, they detested how only the well-to-do seemed to be able to draw upon the status-quo power of the American state and, in their minds at least, use it at the expense of hard-working common folks like themselves. Their resistance sprang from this more radical strand of populist defiance and sense of egalitarian justice.

Intra-regional conflict has often disappeared in stereotypical portrayals of a monolithic rural Ozarks. Ironically, despite the sensationalized and homogenous image of the southern 
mountains as the domain of authority-defying and liquor-gulping mountaineers, many Ozark residents had come to support strong government regulations on the liquor trade, and, increasingly, outright prohibition by the early twentieth century. Temperance advocates in the region's largest towns and trading centers had long crusaded against the "evil drink," since even before the Civil War, but more and more rural folks in the countryside began demanding the implementation of new laws and enforcement to curtail the alcohol trade amid the social, cultural, and economic changes brought on by industrialization in the region in the late $1800 \mathrm{~s}{ }^{5}$ As historian Bruce E. Stewart explains in his study of the prohibition movement in Southern Appalachia, temperance reformers' "critique of alcohol culture and distilling was finally accepted because it made practical sense to many rural denizens who, adapting to a changing economic environment, discovered that preindustrial drinking mores fit poorly with the demands of life and labor in the New South."

The sinful and boisterous behavior emanating from new railroad, timber, and mining camps and commercial centers throughout the region shook the traditional social order, much like the increased presence of new blacks, and began to convince many hill folks that alcohol "has been at the bottom of more crimes and heartaches than almost every thing else combined," as one resident of the railroad town of Imboden put it. Many rural churches began teaching about the sins of alcohol that evangelists in towns and cities had shouted from their pulpits for

\footnotetext{
${ }^{5}$ On early temperance crusading in larger towns and urban areas, see Ben F. Johnson III, John Barleycorn Must Die: The War Against Drink in Arkansas (Fayetteville: University of Arkansas Press, 2005), 10-16. In his recent dissertation, historian Matthew Hernando explains that anti-liquor and anti-vice sentiments lay behind several instances of vigilante activity in Christian and Douglas counties in the Missouri Ozarks in the late 1880s. Matthew Hernando, "The Bald Knobbers of Southwest Missouri, 1885-1889: A Study of Vigilante Justice in the Ozarks,"(unpublished dissertation, Louisiana State University, 2011), 146-159.

${ }^{6}$ Bruce E. Stewart, Moonshiners and Prohibitionists: The Battle Over Alcohol in Southern Appalachia (Lexington: University of Kentucky Press, 2011), 6.
} 
decades, appealing to the "moral side" of local citizens and public officials and "trusting and praying for the complete annihilation of the Liquor Traffic in Arkansas." In the 1912 general election, for instance, anti-liquor advocates led a flawless voting campaign—probably through local churches - among small farmers in Marion County's Bearden Township who resided just to the north of Rush, a rowdy and rapidly-growing zinc mining town. One hundred percent of the voters there opposed the state's issuance of distilling and dispensary licenses in the election, the only legal means of buying and selling alcohol in Arkansas. ${ }^{7}$

Rural anti-liquor sentiment, in fact, had risen rather abruptly in Arkansas during the last two decades of the nineteenth century and became the most decisive factor in the state's march toward statewide prohibition in 1915. In 1882, only 36.3 percent of the voters in Arkansas favored a ban on the state's licensing of saloons and distilleries within their respective voting precincts, most of whom resided in larger towns and cities. By 1894, however, a majority of Arkansas voters wanted to ban liquor licenses in their local precincts. Although voting returns fluctuated back and forth by a few percentage points during subsequent elections over the next ten years, opinions at the polls indicated by 1904 that most rural Arkansawyers aimed to steer their state up the "progressive" road of prohibition. Indeed, for many rural folks the anti-alcohol crusade fit squarely within the broader political culture of populist reform, as temperance advocates and prohibitionists attacked America's "liquor trusts" and "King Alcohol" who filled their coffers by preying on humble families and communities. Their populist vision entailed

${ }^{7}$ J.C. Poindexter to George W. Hayes, February 2, 1915, George Washington Hayes Papers, box 2, folder 56, Arkansas History Commission, Little Rock; Raymond Arsenault, The Wild Ass of the Ozarks: Jeff Davis and the Social Bases of Southern Politics (1984; Knoxville: University of Tennessee Press, 1988), Appendix B, 266. 
regulating and corralling the special "whiskey interest" in order to protect and promote the prosperity and well-being of "the people."8

Some of the most significant political pressure for heavier government regulations on the liquor trade in Arkansas, in fact, came from the Ozarks. In January 1901, for instance, state senator N.J. Carlock of Madison County introduced a bill that, if passed, would have added to the state's existing local regulations by requiring any person who wanted to purchase alcohol in Arkansas to buy a $\$ 5$ license from the county clerk. In cases of violations, the law would impose a $\$ 100$ fine each on both the buyer and the seller. Though the "Whiskey License Bill" was handily defeated the first time it came to the floor of the state senate, some even saying that it "was considered a joke" initially, the persistent senator from the Ozarks managed to have it brought up for another vote in April. This time, much to the surprise of Russellville's CourierDemocrat, the senate passed "the celebrated whiskey drinking bill," and hopeful anti-liquor proponents predicted that its passage in the general assembly "will virtually result in abolishing the saloon traffic in this State."9

Carlock's bill ultimately failed in the lower house, but the strong political support it had received further energized temperance and prohibition advocates and revealed the growing antiliquor sentiments in the rural Ozarks. After all, as an ever increasing number of hill folks adapted to the new political economy, the economic importance of alcohol manufacturing to many farm communities had waned considerably by the late nineteenth and early twentieth centuries, particularly for those with better and more economical access to improved

\footnotetext{
${ }^{8}$ Arsenault, Wild Ass of the Ozarks, Table 14, 150; Michael Kazin, The Populist Persuasion: An American History (New York: Basic Books, 1995), 86-96.

9 “That Whiskey License Bill," Courier-Democrat (Russellville), April 18, 1901.
} 
transportation networks for shipping crops to market. Like a growing number of Appalachian "country folk" in Stewart's study, many rural Ozarkers, now "more connected to the market economy and embracing New South rhetoric, increasingly yearned to 'improve' themselves both economically and morally" and decided that government was obligated to more strictly regulate or completely ban the sale and consumption of alcohol in order to promote their families' and communities' general welfare. ${ }^{10}$

Voting returns on local-option elections that determined whether or not the state would be allowed to issue liquor licenses bear out the influence of agricultural marketing opportunities on sentiments about alcohol in the Ozarks. In Washington County, the home of the University of Arkansas and one of the most prosperous agricultural areas of the state, voters in 26 of the county's 29 townships voted against the issuance of licenses in 1906, and the anti-liquor forces lost by fewer than five percentage points in each of the other three precincts. ${ }^{11}$ With access to no fewer than five railroad lines (including spurs) that crisscrossed the county and a comparatively larger number of improved overland roads that ran through the gently-rolling terrain, not to mention the county's relative proximity to the navigable Arkansas River, farmers working the fertile soils of the Springfield Plain in the northwestern corner of the Arkansas Ozarks generally enjoyed extensive and diverse marketing opportunities. These farmers also tended to benefit the most from scientific farming programs administered by the state's federally-funded Agricultural Experiment Station, established in 1888 at the pubic university in Fayetteville. The state's agricultural commissioner, A.G. Vincenheller, bragged in October 1897 that orchard farmers in Washington and Benton Counties "have money to burn" from their "immense" sales to Kansas

\footnotetext{
${ }^{10}$ Stewart, Moonshiners and Prohibitionists, quotation on 172.

${ }^{11}$ Arsenault, Wild Ass of the Ozarks, Appendix B, 260-270.
} 
City, Canadian, and English firms, and this prosperity only added to area wheat farmers' lucrative markets. ${ }^{12}$ From the late nineteenth century through the twentieth, in fact, Washington County claimed "the highest agricultural income of any county in Arkansas."13 Distilling and selling crops as liquor, then, made less economic sense to better-off and better-connected farmers on the prosperous Springfield Plain. Free from any economic dependence on the manufacture and sale of whiskey and convinced that the "liquor problem" lay at the root of moral depravity and impeded further progress, an overwhelming majority of Washington County residents insisted that "sinful" alcohol had no place in their society.

Anti-liquor proponents held majorities in many other counties throughout the rural Ozarks by the early twentieth century as well. But sentiments about alcohol were more evenly divided in rugged and remote counties with more limited transportation networks and fewer agricultural opportunities — as well as a lack of capital and resources to exploit those few that were available. Thus, in these areas, converting crops into marketable whiskey proved economically important for some. In 1912, for instance, voters in 10 of Sharp County's 19 townships in the eastern Ozarks voted against the issuance of liquor licenses, while pro-liquor proponents carried 8 precincts and residents in one township, Lebanon, split their votes exactly in half. The pro-liquor forces won a slim majority of the precincts in Marion County in the central part of the region, carrying 11 townships while the antis won $10 .{ }^{14}$ Though a railroad and some limited road improvements had traversed both of these counties and several others by the first few years of the twentieth century, less fertile soils and difficult terrain, poorly developed

\footnotetext{
12 "Have Money to Burn," Arkansas Gazette, October 5, 1897.

${ }^{13}$ Matthew B. Kirkpatrick, "Washington County," Encyclopedia of Arkansas History and Culture (http://www.encyclopediaofarkansas.net/encyclopedia/entry-detail.aspx?entryID=813), accessed August 8, 2013. ${ }^{14}$ Arsenault, Wild Ass of the Ozarks, Appendix B, 260-270.
} 
transportation networks, the vagaries of distant markets, and a shortage of capital and resources to invest in new techniques and equipment among generally poorer small hill farmers in these areas meant that new opportunities to prosper were typically reserved for a more exclusive class. ${ }^{15}$ Larger landowners, prominent businessmen who owned the local mills and gins, speculators who purchased products from local farmers for resale to large firms in American cities, and, of course, the merchants and lenders who controlled the systems of local credit typically profited the most from the New South's market developments. But the Ozarks' fuller integration into the national and international political economy often brought more burdens than blessings for cash- and resource-strapped family farmers in the heart of the region. "Like a great threshing machine,” as Appalachian historian Charles D. Thompson Jr. puts it, "an increasingly mechanized agriculture fueled by fluctuating export markets began chewing up and spitting out small farmers like chaff, even as it bagged and hauled off their products for profit elsewhere."17

Since prospering, or even surviving, amid an expanding, albeit uneven, market-oriented capitalist economy became less and less hopeful for many small-farm families in the Ozarks backcountry, some of them found that marketing their crops as liquor made the best economic sense-despite growing anti-alcohol sentiments among many of their fellow Ozarkers. Wayman Hogue, a rural school teacher in remote Happy Hollow, recalled the economic necessities of

\footnotetext{
${ }^{15}$ Nancy Orr, "Sharp County," Encyclopedia of Arkansas History and Culture (http://www.encyclopediaofarkansas.net/encyclopedia/entry-detail.aspx?entryID=809), accessed August 9, 2013; Sherry Sanders-Gray, "Marion County," Encyclopedia of Arkansas History and Culture (http://www.encyclopediaofarkansas.net/encyclopedia/entry-detail.aspx?entryID=789), accessed August 9, 2013.

${ }^{16}$ For a widely-cited study on of the displacement of small yeoman farmers amid the emergence of the New South political economy in the Georgia Upcountry, see Steven Hahn, The Roots of Southern Populism: Yeoman Farmers and the Transformation of the Georgia Upcountry, 1850-1890 (New York: Oxford University Press, 1983).

${ }^{17}$ Charles D. Thompson Jr., Spirits of Just Men: Mountaineers, Liquor Bosses, and Lawmen in the Moonshine Capital of the World (Urbana: University of Illinois Press, 2011), 131.
} 
moonshining for the farm family that he boarded with during the late nineteenth century. The family's patriarch, Mr. Garrison, who was also a member of the local school board, told Hogue that he had no choice but to distill his corn and sell it as liquor if he hoped to make any money as a small farmer. As Hogue explained it:

There was no demand for corn in the valley, except a few bushels now and then. Therefore, in order to market his corn, Mr. Garrison must haul it forty or fifty miles distant to the river farms where they raised mostly cotton. The capacity of a two-horse wagon was about twenty bushels in the ear. If he succeeded in finding a buyer for his corn, the price was not more than fifty cents a bushel, which amounted to ten dollars a load for his corn. He could not really make the trip for that, so the expense of marketing his corn was more than he received for it...[but] by converting this corn into whiskey, he netted a good profit. Ordinarily a bushel of corn would run off about a gallon and a quart of whiskey, which he could sell for something like two dollars and a half a gallon. Therefore, Mr. Garrison's surplus crop of corn, when distilled into whiskey, brought him a gross sum of six or seven hundred dollars, which was a lot of money for one family...If he was able to run off ten gallons a day and sell it for twenty-five dollars, he considered he was making big money. ${ }^{18}$

It amazed Hogue, in fact, to see just how economically vital distilling was to this rural farm family and others in the area. This was more than evident, he thought, because, although he knew that a few of the men were apt to drink a little ever now and then and on special occasions,

\footnotetext{
${ }^{18}$ Wayman Hogue, Back Yonder: An Ozark Chronicle (New York: Minton, Balch \& Co., 1932), 265-266.
} 
he always noticed when he visited their stills that "none of them were drunk or even drinking." "They probably considered that they were at work," Hogue guessed, and viewed making moonshine as a central part of their farming and family business ventures. ${ }^{19}$

Even farm families in Happy Hollow with no direct interest in the Garrisons' stills or those of others in the community, Hogue further explained, benefitted economically from the moonshining business. The Garrisons and other distillers frequently bought up the surplus corn or other grains from area farmers, providing one of the few—if not the only—dependable and profitable markets for their produce in the community. In addition, some local farmers worked for supplemental income as part-time laborers at the stills, especially during slow periods in the agricultural cycle, or found employment hauling and selling liquor for the moonshiners. Hogue also seemed surprised to discover that "many of the men who worked at the stills belonged to the church.” The local church at times even made special accommodations for its moonshining members during particularly busy times, offering services on both Saturdays and Sundays to provide extra opportunities to attend. "Hence," Hogue remembered, "the whiskey industry was considered by the natives of Happy Hollow to be an asset to the community." ${ }^{20}$ Some small farmers, then, especially in backcountry areas, dissented from the opinions of others in the better-off rural and small-town Ozarks that favored government-enforced prohibition.

Illicit distilling in the Ozarks backcountry during the late nineteenth and early twentieth centuries, however, had little to do with the persistence of an exceptional mountain culture that had remained unchanged since the earliest pioneers brought their Scots-Irish traditions with

\footnotetext{
${ }^{19}$ Ibid., 263.

${ }^{20}$ Ibid., 263, 266.
} 
them. Instead, the production of moonshine whiskey in the rural Ozarks actually appears to have increased and "reached its zenith," as a former deputy collector later recalled, during the late nineteenth and early twentieth centuries, as a result of new market incentives created from the forces of an interdependent and government-assisted political economy that encouraged industrialization and centralized, capital-intensive agriculture. ${ }^{21}$

While some whiskey was certainly manufactured and sold for local consumption, Ozarks moonshiners found their most lucrative markets in rapidly-developing urban centers such as Little Rock, Fort Smith, and Springfield, Missouri, in new timber and mining districts in the region and adjoining areas, and in expanding county-seat towns and railroad centers. The federal government's opening of the Indian Territory (present-day Oklahoma) to white settlement and industrial and agricultural development in 1889-90 also provided marketing opportunities for moonshine manufacturers in the western and central parts of the region. Distillers in the eastern Ozarks, meanwhile, frequently found dependable buyers in the cotton and rice districts of eastern Arkansas's Delta region, large parts of which were undergoing massive government-funded drainage projects, road and railroad building, and other economic developments by the early 1900s. ${ }^{22}$ Mr. Garrison of Happy Hollow also explained that illicit Ozarks moonshine proved highly attractive to many licensed liquor dealers, because they "got it for less money than...from the legalized distilleries" whose wholesale prices were driven much higher by government

\footnotetext{
${ }^{21}$ Isaac Stapleton, Moonshiners in Arkansas (Independence, MO: Zion's Printing and Publishing Co., 1948), Introduction.

${ }^{22}$ As we shall see, the following story about the Bruce affair will illuminate the connections with urban centers such as Little Rock and Fort Smith, as well as the Indian Territory. For an anecdotal example of moonshiners in the eastern Ozarks and markets in the Delta, local historians and descendants of several generations of hill families residing on Hutchinson Mountain in Independence County say that moonshiners in that area typically sold their product to buyers in Newport, Jackson County. Susan Mosier, telephone interview with author, May 25, 2010; and Mildred Thomas, telephone interview with author, May 28, 2010. On government-subsidized developments in the lowlands of eastern Arkansas, see Jeannie M. Whayne, A New Plantation South: Land, Labor, and Federal Favor in Twentieth-Century Arkansas (Charlottesville: University Press of Virginia, 1996).
} 
taxes. $^{23}$ As historian Charles Thompson Jr. so deftly states it: "Choices people made when turning to liquor production have to be judged in the context of opportunities people had. What farmers chose to produce in their world had a lot to do with broad national policies and economics." ${ }^{24}$ Harve Bruce and his fellow moonshiners in the mountains of northwestern Van Buren, northeastern Pope, and southern Searcy counties stood among these hill farmers trying to make their way in the national political economy's new rural environment, and they determined that making and selling liquor afforded the best chance of prospering and maintaining their livelihoods.

Born to yeoman farmers in Georgia around 1847, a young Harve Bruce moved with his family to Winston County, Alabama, by 1860, where his father now worked as a tenant farmer. When the Civil War broke out, his father, William, enlisted in the Confederate Army, and Harve's mother, Sarah, appears to have moved the family to Cherokee County, North Carolina, probably to live near relatives during her husband's absence. When Harve turned sixteen in 1863, he too joined the Confederate Army and served throughout the remainder of the war. After the war ended, the Bruce family reunited and spent some time in Tennessee before returning to North Carolina by 1870 , where William either bought or inherited a small farm and Harve worked as a farm laborer. The following year, Harve married Hannah Cotter of Sevier County, Tennessee, and they soon started a family of their own in the same area. Sometime in

\footnotetext{
${ }^{23}$ Hogue, Back Yonder, 264.

${ }^{24}$ Thompson Jr., Spirits of Just Men, xxvii.
} 
1878, the Bruces headed west to settle in Archey Valley Township in Van Buren County, Arkansas, where Harve initially supported his family as a wage laborer. ${ }^{25}$

By the mid-1890s, Bruce and his family acquired a farm of their own in Wheeler Township. In 1894, Bruce, like many other Ozarkers, took advantage of the federal government's homesteading programs and received a 160 -acre land grant on poor and rugged Oak Mountain in northwestern Van Buren County. Bruce supplemented his small farm income by working part-time as a local sheriff's deputy during the early 1890s. Amid increasingly difficult times for small yeomen in rural America, Bruce, unlike many of his neighbors, fortunately managed to keep from mortgaging his farm by the end of the decade. ${ }^{26}$ To do so, however, he embarked upon a farming and business venture that many of his fellow Ozarkers had come to frown upon as backward, unprogressive, and immoral.

Indeed, Bruce - a Sunday School man all of his life who had undergone a conversion experience and "professed religion" in the early 1890s—apparently had only recently begun manufacturing and selling alcohol when he and his neighbor, Turner Skidmore, formed a distilling partnership near their homes on Oak Mountain during the summer of 1896. Just who their main buyers were remains uncertain, but Bruce and his partner likely discovered a strong new demand for corn liquor in the area's growing timber camps and mining districts, especially

\footnotetext{
${ }^{25}$ Manuscript Census Returns, Eighth Census of the United States, 1860, Population Schedules, Winston County, AL; Ninth Census, 1870, Shoal Creek Township, Cherokee County, NC; Tenth Census, 1880, Archey Valley Township, Van Buren County, AR; "The Legend of Harve Bruce," OakSpringsMountai Ranch.com (http://oakspringsmountainranch.com/Legend_of_Harve_Bruce.html); Ancestry.com, Arkansas Confederate Pension Records, 1891-1935, [online database](Provo, UT: Ancestry.com Operations, Inc., 2011).

${ }^{26}$ Manuscript Census Returns, Twelfth Census of the United States, 1860, Population Schedules, Wheeler Township, Van Buren County, AR; Lynn Banard Risener, "Original Grantee's Land, Van Buren County, Arkansas: Township 11N, Range 17W" (http://www.rootsweb.ancestry.com/ arvanbur/LandRecords/111); Bruce v. State, Transcript of Testimony, Series IV, Box 15, Folder 684 (1900), Arkansas Supreme Court Briefs and Records, UALR/Pulaski County Law Library Special Collections, 105.
} 
in the booming zinc and lead fields of nearby Searcy County to the north. Testimony unearthed later during Bruce's trial indicates, furthermore, that he, Skidmore, and their moonshining comrades may have also been doing business with the owner of a wagon yard in Little Rock. In addition, they may have located profitable market connections in the newly-developing Indian Territory through Bruce's brother-in-law and other relatives and acquaintances who had recently moved there. ${ }^{27}$ Amid the new economic forces that made competing with more highlycapitalized and mechanized farmers in other regions—as well as other parts of the world — more and more difficult for small-family farmers in the Ozarks, Bruce and several of his neighbors had found a market niche that just might keep them in business. Unfortunately for them, they would have to conduct this business outside the parameters of the law.

Many Ozarkers resented Bruce's and other backcountry hill farmers' illicit economic activities, believing the liquor traffic to be the main culprit behind vice, crime, and social disruption in their towns and communities and, thus, the most important impediment to "progress" and "respectability." The impetus for rooting out illegal moonshining in the mountains of Pope, Van Buren, and Searcy counties during the late 1890s, in fact, came not from government bureaucrats in Washington, D.C., or even Little Rock, but from concerned, well-todo locals who were determined to clean up the "deplorable" conditions in their region.

\footnotetext{
${ }^{27}$ James J. Johnston, "Searcy County," Encyclopedia of Arkansas History and Culture (http://www.encyclopediaofarkansas.net/encyclopedia/entry-detail.aspx?entryID=806), accessed August 8, 2013. On Bruce's Little Rock and Oklahoma connections, see Bruce v. State, Transcript of Testimony, 71, 133. Turner Skidmore testified that he and Bruce had first begun to operate their still about twelve months before federal marshals confronted them in the summer of 1897, p. 61. Longtime friend, Mr. Sutton, who had grown up with Bruce back east and now resided in the area and went to church with him, testified in court that Bruce's reputation was "very good up to the time he started making wild cat liquor," pp. 88-89.
} 
Pope County resident John T. Burris, in fact, initiated the first excursions by federal marshals into the area. Born in 1849 to a prominent tanner in Pope County, Burris resided and owned a farm in Griffin Township in the northern part of the county by 1880, where he and his wife raised four young children and employed a twenty-three-year-old tenant farmer from Tennessee. In addition to his agricultural endeavors, the well-to-do Burris worked as a skilled mason and carpenter and later ran a sawmill and gristmill. At some point, he also secured a government contract to carry the mail for the U.S. Postal Service and appears to have moved his family to Russellville, Pope County's seat of government, by the 1890s. ${ }^{28}$ A devout Baptist and prohibitionist, Burris abhorred the illegal manufacture and sale of whiskey on the rise in his section and traveled to Little Rock in November 1896 to meet with Arkansas's head collector of the federal government's Internal Revenue Service. Burris requested that the government dispatch a party of officers into the Ozarks to "capture the miscreants and destroy their manufacturing plants," but the collector regretfully informed him that his office lacked the necessary funds at the moment to authorize such a mission. Pleading further with the revenue official, Burris even offered to "pilot the posse, and if they failed to find things just as he had described them, he would pay all the expense, thus relieving the United States of any expense whatever," but all he got was a promise to keep his request in mind. Burris left Little Rock disappointed that no definite plans had been made to deploy federal lawmen to the mountains, but by the summer of 1897 federal officials finally contacted Burris to ask him to help guide a

\footnotetext{
${ }^{28}$ Dee Blakley, “John Thomas Burris,” Shakin' the Family Tree (http://wc.rootsweb.ancestry.com/cgibin/igm.cgi?op=GET\&db=sharpchick\&id=156), accessed July 12, 2013; Manuscript Census Returns, Tenth Census of the United States, 1880, Population Schedules, Griffin Township, Pope County, AR.
} 
team of marshals and revenuers in a concerted hunt for Ozark moonshiners and their stills in his home area. $^{29}$

Burris and the feds made one of their first "successful" raids into "the notorious moonshine district in the mountains north of Russellville" around the third week of August, arresting five local farmers, destroying "six illicit stills with a total capacity of 400 gallons," and disposing of "about 2,000 gallons of mash and beer." "30 Bruce's and Skidmore's distillery soon made the top of Burris's and the federal lawmen's list. Burris and the officers enlisted the help of Tom Barnes, a poor resident of Snowball in Searcy County who had relocated there from Putnam County, Tennessee, sometime during the 1880s. Barnes had known Bruce for nine or ten years and occasionally worked for him and other local moonshiners hauling and selling liquor. He was also a regular customer of theirs, buying three or four gallons of whiskey at a time for his own drinking. Unbeknownst to Bruce and Skidmore, Barnes turned traitor when Burris and the federal officers offered him $\$ 10$ to show them the whereabouts of Bruce's and Skidmore's still in northwestern Van Buren County. Barnes agreed but told them he would only take them to the vicinity of the still, fearing that his old friends might see him. ${ }^{31}$

Once Barnes took them to Oak Mountain and turned back, Burris and the feds began searching the terrain for Bruce's and Skidmore's still. Having no luck, Burris and the officers decided to pay Bruce a visit at his house. Burris, who knew old man Bruce and called him "Uncle Harve," believed that he could convince him and Skidmore to surrender their still and turn themselves in. When they arrived at the farmhouse, however, only Bruce's wife and

\footnotetext{
${ }^{29}$ Stapleton, Moonshiners in Arkansas, Introduction, 5.

30 “Successful Moonshine Raid," Russellville Democrat, August 26, 1897.

${ }^{31}$ Bruce v. State, Transcript of Testimony, 47-50.
} 
children were at home; he and Skidmore were out working at their still. The officers convinced Bruce's wife, Hannah, to send her older daughter out to notify Bruce that the U.S. marshals were at the house and wanted to speak with him. When Bruce's daughter found him and gave him the message, he and Skidmore quickly headed into the woods to hide. ${ }^{32}$

According to Bruce's recollection, when his daughter returned to the house without him, the senior officer, Deputy Revenue Collector J.P. King—who was also an Ozarks resident from the town of Ozark in Franklin County—grew impatient and threatened to "handcuff" and arrest her. Meanwhile, Bruce's brother, Alford, had arrived at the house and discussed the situation with the officers, so he went to Bruce's hiding place to tell him that if he did not go talk with the marshals then they were going to take his daughter with them. A now angry Bruce sent his brother back to the house to tell Burris that he would meet him out in the field to talk, but that he had better come unarmed and without King or any of the other men. Burris agreed, and Bruce's wife and daughter accompanied him to the field to meet the moonshiner. ${ }^{33}$

When they met in the field, Bruce asked Burris if King and the officers had a warrant for his arrest, and Burris replied that they did not have one yet. Bruce, now undoubtedly as resentful as ever about elite Ozarkers like Burris and King using — and abusing — their privileged positions to exert government power against hard-working farm families like his, asked what grounds the officers had, without a warrant, in threatening to arrest his innocent daughter. "I respect Mr. King and do not want to hurt anybody," Bruce sternly warned Burris, implying that he might get violent if the officers insisted on acting unjustly. Burris attempted to diffuse the situation,

\footnotetext{
${ }^{32}$ Ibid., 126-127; Stapleton, Moonshiners in Arkansas, 1.

${ }^{33}$ Bruce v. State, Transcript of Testimony, 127; "Will Be Avenged," Arkansas Gazette, September 7, 1897.
} 
pleading with Bruce to hand over his still and turn himself in, since it was now a well-known fact that he and Skidmore were making illicit moonshine and that the lawmen would not give up until they found their still and arrested them anyway. He also told Bruce "that in all probability sentence would be suspended during his good behavior" if he would willingly submit now. But Bruce refused, saying that he "would go when the proper time comes," only after he had "straighten[ed] up [his] business" and saw "what they [the authorities] did with the other boys" in the area who had already been arrested. Apparently, Burris also informed Bruce that the law would soon be after him for his and Skidmore's suspected involvement in another altercation a few months earlier between moonshiners and officers in neighboring Cleburne County, in which a lawman was shot in the leg and later died from infection. When Bruce questioned Burris about just how much evidence they had on him, the anti-liquor crusader had to admit that he did not know "whether they could get enough to get an indictment." Unable to convince Bruce to go with him, Burris returned to the house to rejoin the officers and continue searching the area for the still. ${ }^{34}$

After his meeting had ended with Burris, Bruce rushed to his and Skidmore's hidden distilling site to quickly disassemble the still and move its components deeper into the woods. Bruce evacuated the site just in time, before Burris and the federal officers came traipsing into the holler later that afternoon and discovered his and Skidmore's manufacturing site. The officers were disappointed to find only an empty stillhouse and a few containers of beer and whiskey. They burned the wooden structure and dumped out the liquor before heading back to

\footnotetext{
${ }^{34}$ Ibid., 127-128; Stapleton, Moonshiners in Arkansas, 2; "Will be Avenged."
} 
Russellville. Bruce remained in hiding for the next few weeks to elude Burris and the federal lawmen and began making plans to leave for the Indian Territory. ${ }^{35}$

Meanwhile, federal marshals in the region ramped up their hunts for moonshiners and distilleries during subsequent weeks. Officers zeroed in on the area in and around northeastern Pope County's Bullfrog Valley, located across the county line to the west of Bruce's farm. Officers had discovered that this place was a hotspot for illicit distilling when federal authorities penetrated the area to break up a notorious ring of counterfeiters who were operating there. The New York Times even reported on the affair in late June 1897, claiming that the arrest of three men, "it is believed, has effectually broken up the once-famous band of counterfeiters known to secret service operators all over the United States as the Bullfrog Valley Gang." Though national and regional journalists apparently never paused to consider the contradictions amid their portrayals of a primitive and isolated Ozark society, they reported that the U.S. Secret Service believed this to be one of the most highly-sophisticated counterfeiting operations in the nation, with connections "in nearly all the principal cities in the country and even...in Toronto, Canada, and the City of Mexico." As federal officers worked to arrest others in connection with the counterfeiting ring during subsequent weeks, they also discovered disturbing levels of illegal liquor trafficking in the area, frequently brought to their attention by local anti-liquor proponents. Upon pronouncing the sentence of one convicted counterfeiter from the area, the federal judge who presided over Arkansas's Western District declared that "[t]here are two things I am going

\footnotetext{
${ }^{35}$ Bruce v. State, Transcript of Testimony, 126, 140-141; Stapleton, Moonshiners in Arkansas, 2.
} 
to break up in this district, and those are counterfeiting and moonshining. Hereafter, I intend to send every man convicted before me of either of those charges to the penitentiary.",36

One federal marshal—and local resident—who doubled his efforts to stamp out illicit economic activities in the mountains was Benjamin Franklin Taylor of Searcy County. Born in DeKalb County, Tennessee, in 1839, a strapping young Taylor moved west to Searcy County, Arkansas, by 1860, where he and his new wife were raising two infant daughters. The Civil War era was a pivotal time for Taylor. Local historians have credited Taylor, an unbending Unionist, with establishing the local Home Guard in the winter of 1862 to protect Searcy Countians and their property from marauding bushwhackers and pro-Confederate bands once the Union Army claimed control of northern Arkansas. He later enlisted in the Union Army's First Regiment, Arkansas Infantry, and then the Third Regiment, Arkansas Cavalry, in which he received a commission as captain in February 1864. Taylor played a leading role in Searcy County politics during Arkansas's Republican Reconstruction period. Elected to represent his county in the state legislature in 1866, he stepped down in 1867 to oversee the all-important process of voter registration in Searcy County. Searcy County's eligible voters then reelected him to serve in the state's general assembly in 1871. The next year Taylor helped organize a local and state political campaign to elect the Liberal Republican-Democratic ticket and Horace Greeley for president in the upcoming national election, denouncing the corruption of the Grant administration and calling for an end to federal Reconstruction in the South. By 1870, Taylor had emerged as a powerful and prosperous man in Searcy County. While he had claimed only $\$ 350$ worth of

\footnotetext{
36 “The Bullfrog Valley Gang,” New York Times, June 28, 1897; “Criminal News,” Arkansas Gazette, June 27, 1897; "Pope County Counterfeiters," Russellville Democrat, August 12, 1897; "Counterfeiter Sentenced," ibid., November 18, 1897.
} 
personal property and no real estate in 1860 , he owned $\$ 2,500$ in personal property and $\$ 2,000$ in landholdings and other real estate by 1870 . In addition to his sizeable farming and landholding interests, Taylor opened a "large steam mill and gin" and sawmill on Calf Creek in 1875, where he added to his growing fortune — at least by Ozarks standards—-by processing and purchasing local hill farmers' corn, wheat, and timber. ${ }^{37}$

Unfortunately for Taylor, his bent for profitmaking made headlines in Arkansas newspapers in January 1880 when a boiler exploded at his Searcy County mill and killed four employees, including his own son-in-law. Reporters alleged that Taylor "had been informed by skillful engineers that, in its condition, the boiler of the engine used in the mill was liable to explode at any time," but he had refused to halt production and replace it. When the boiler finally exploded a few days before Christmas in 1879, his son-in-law, Wade Campbell, "was blown through the top of an apple tree, and descended into the lint-room connected with the mill" where he lay dead, and three other employees were "literally blown to pieces.",38

Despite the bad publicity surrounding the incident, Taylor maintained his prominent and powerful stature in Searcy County. He quickly repaired and reopened his mill in the 1880s, started a profitable mercantile business, and became one of the cash-starved area's most important financial creditors. He also served as the superintendent for the Snowball Sunday School. Although Republicans lost the Arkansas legislature in 1874 to the "Redeemers,"

37 "Benjamin Franklin Taylor," Searcy County Ancestor Information Exchange 16 (February 2007): 123-124; Manuscript Census Returns, Eighth Census of the United States, 1860, Population Schedules, Mountain Township, Searcy County, AR; Ninth Census of the United States, 1870, Calf Creek Township, Searcy County, AR; B.T. Campbell, "Some Early Calf Creek History," Searcy County Ancestor Information Exchange 4 (December 1994): 307.

38 “Accident in Searcy County," Arkansas Gazette, January 4, 1880; “That Saw Mill Explosion,” ibid., January 16, 1880; "Benjamin Franklin Taylor," 124-125. 
marking the end of Reconstruction in the state, and the Democrats even took control of unionistleaning Searcy County during the next few years, local voters elected Taylor to the state legislature once again in 1880 and to another term in 1882. Interestingly, Taylor applied as an invalid for a Civil War pension in August 1890 after the U.S. Congress enacted a new Dependent Pensions Act, citing an injury to his right hand that he suffered while working at his mill in 1885 . By the 1890s, Taylor was "the wealthiest man" and one of the most powerful figures in Searcy County. Soon after President William McKinley took office in 1897 and placed Henry M. Cooper in charge of the U.S. Marshals Service, Taylor, one of Arkansas's most loyal Republicans, received an appointment as a federal deputy marshal. Upon receiving word of his appointment, Searcy County's Marshall Republican proudly reported the news, confidently predicting that Taylor "will make a good Marshall and should have the support of all lovers of law and order in any effort to suppress the wild cat distiller. These individuals are becoming too numerous in this section and are becoming so obstructive to good government that many men who have heretofore held aloof and took no decided stand against them are coming out and demanding that they be suppressed." 39

Taylor teamed up with a fellow deputy marshal, native and well-born Ozarker Joe M. Dodson, to begin scouring the hills for local farmers engaged in the manufacture and sale of mountain dew in this "hot-bed" area of lawbreaking economic activities. Joe Dodson was born in 1868 to a well-to-do and politically influential Ozarks family. His father, John M. Dodson, a physician, farmer, and former slaveholder, was born in Georgia in 1814, and he and his family

\footnotetext{
39 "Benjamin Franklin Taylor," 125; Ancestry.com, U.S. Civil War Pension Index: General Index to Pension Files, 1861-1934 [online database] (Provo, UT: Ancestry.com Operations, 2000); "MM Taylor, et al vs. CT Stone \& AJ Stone, his wife," Searcy County Ancestor Information Exchange 7 (February 1998): 407; Campbell, "Some Early Calf Creek History"; "Two Killed," Arkansas Gazette, August 31, 1897; Marshall Republican, July 1, 1897; "Will be Avenged."
} 
had lived in South Carolina and Alabama before his first wife died in 1846. Around 1849, John M. remarried and headed west to the Sylamore area of what was then part of Izard County but was later included in Stone County when it was created in 1873. There Joe and several other children were born to John M. and his second wife. A staunch Democrat and local party leader, several of the prominent Stone County farmer-physician's sons and grandsons would go on to enjoy successful political careers in Arkansas, Texas, and Oklahoma. Though the influential patriarch died in 1889, the Grover Cleveland administration commissioned his twenty-five-yearold son Joe to a deputy U.S. marshal position in 1893, and, despite the shift to Republican control over federal patronage when McKinley entered the White House, the U.S. Marshals Service kept him on its staff in $1897 .^{40}$

Ironically, Joe Dodson, an apparent champion and defender of law and order, also had connections to the other side of the area's illicit economic activities, though he never lived to see the extent of these connections unfold in the public eye. On June 26, federal officials arrested several area residents in connection with the Bullfrog Valley counterfeiting ring, including a member of the Dodson family, according to the Arkansas Gazette. If this was Joe Dodson's younger brother, Lit, authorities must have soon released him due to a lack of evidence. But in October, just over a month after Joe's tragic death in the shootout with Harve Bruce, lawmen arrested Lit Dodson again on counterfeiting charges in the city of Fort Smith on the Oklahoma line. Other friends of the Dodson family were also arrested on counterfeiting charges, including Dr. John Tubbs, a second-generation physician and son of a prominent family in Timbo in

\footnotetext{
${ }^{40}$ Manuscript Census Returns, Tenth Census of the United States, 1880, Population Schedules, Sylamore Township, Stone County, AR. On John M. Dodson's history and a portion of his offspring's political careers, see Luther B. Hill, A History of the State of Oklahoma, Vol. II (Chicago and New York: Lewis Publishing Co., 1910), 299-300.
} 
western Stone County. News of their arrests shocked many observers, and a number of the region's prominent citizens, including the editor of Searcy County's Mountain Wave, refused at first to believe that these elite men "who have heretofore stood high in the estimation of the people of Stone County" could be guilty of such a crime. The Wave, which rarely missed an opportunity to defend its region's respectable image, even went so far as to say that it "does not think there is such a [counterfeiting] gang, nor that Tubbs or Dodson is connected with it if there is." Instead, it insisted that a handful of interlopers who had recently moved up to Blue Mountain must be the true culprits responsible for producing and circulating fake money in the region. $^{41}$

The Wave's speculation about outsiders being the real criminals, in fact, advancedselectively at least—part of a theory made by the New York Times. The New York paper had speculated that the Bullfrog Valley Gang must be a group of outsiders who sought refuge from the law in the isolated Ozark Mountains and then "settled there like rough mountaineers...[and] adapted themselves to their customs to such a degree that the residents of the county paid no attention to them"- though the Wave, of course, rejected the national paper's more degrading portrayal of the local culture, figuring that any reasonable person might have assumed that the operation was simply a new printing business starting up in this age of mass journalism. ${ }^{42}$ Whatever the angle, such theories about clueless or altogether innocent mountaineers could not withstand the evidence as facts unfolded and exposed the extensive local involvement in this

\footnotetext{
41 “Criminal News"; "Was Counterfeit,” Mountain Wave, October 8, 1897; “Is Lit One of Them,” ibid., October 8, 1897.

42 "The Bullfrog Valley Gang"; "Is Lit One of Them."
} 
highly-complex counterfeiting operation that had been on the U.S. Secret Service's most-wanted list for quite some time.

Undercover detectives investigating the passing of counterfeit money in several American cities picked up on a lead when a printing press and other suspicious materials were shipped out by rail from Chicago. They eventually tracked the shipment to a railroad depot in Pope County, and secret service agents and federal marshals descended upon the region to begin hunting down the perpetrators. The New York Times and other observers pointed to the area's geographic isolation, backward and gullible locals, and an absence of competent law enforcement as the key draws for the counterfeiters in their decision to headquarter their operation in mountainous Bullfrog Valley. The Arkansas Gazette, however, explained that the counterfeiting ring had strategically chosen the place because it straddled the federal government's legal boundary between the U.S. court system's eastern and western districts in Arkansas. Thus, the counterfeiters hoped that Bullfrog Valley's complicated legal location would create confusion and disputes over jurisdiction among officials, which in turn might encourage them to direct their energies in less ambiguous parts of their respective districts. Nevertheless, once it became clear that the counterfeiting ring was operating in the mountains of Pope County, federal officials in both Arkansas's eastern and western districts closely cooperated in working together to hunt down the guilty parties. ${ }^{43}$

By the end of the summer, authorities had rounded up several suspects in connection with the counterfeiting operation. The supposed ringleader, George Rozelle, managed to escape,

\footnotetext{
43 "The Bullfrog Valley Gang"; "Criminal News"; Stephen Mihm, A Nation of Counterfeiters: Capitalists, Con Men, and the Making of the United States (Cambridge, MA: Harvard University Press, 2007), 157-159.
} 
however, and took much of the printing equipment with him. Secret Service agents tracked down Rozelle two years later in southeastern Missouri, where he was living under an alias, but he eluded their attempts to arrest him once again. By the time federal authorities finally caught up to him again several months later, he had moved back to the Arkansas Ozarks to settle on a farm in Cleburne County's Goff Cove. But as the officers closed in, hoping to finally arrest the notorious ring leader, they discovered that he had died and found only his grave. ${ }^{44}$

Though they failed to get the Bullfrog Valley Gang's head honcho, federal officers had arrested about fifteen men by the end of August 1897, most of them locals. The New York Times later reported after interviewing Secret Service officials that at least "[t]wo or three rich citizens of the neighborhood were said to have furnished money to the enterprise," who realized the profits that this business venture could bring in such a cash-starved region of small-family farmers and the potential stimulation to the local economy. Indeed, local newspapers such as Searcy County's Mountain Wave seemed to suggest that it and most local residents might reasonably sympathize with those political populists who "advocate the [government's] free coinage of paper money" as a boon to the local economy, though counterfeiters who "actually practice it" without authority, it made clear, were another matter. As historian Stephen Mihm writes, "In...capital-poor region[s] where money remained in short supply (and where specie and the genuine bills of more reputable banks disappeared into private hoards and flowed to eastern cities for redemption), counterfeiters catered to an insatiable demand for credit." ${ }^{, 4}$ Some local

\footnotetext{
${ }^{44}$ Ernest Dumas, "Bullfrog Valley Gang," Encyclopedia of Arkansas History and Culture (http://www.encyclopediaofarkansas.net/encyclopedia/entry-detail.aspx?entryID=7378), accessed August 16, 2013; "How Secret Service Men Track Criminals," New York Times, May 12, 1901.

45 "How Secret Service Men Track Criminals"; "Is Lit One of Them"; Mihm, A Nation of Counterfeiters, 159-160.
} 
elites, like Stone County's John Tubbs and Lit Dodson, then, could not resist the lucrative opportunities.

John Tubbs's and Lit Dodson's associations with the Bullfrog Valley counterfeiting ring remained hidden until authorities arrested them in the city of Fort Smith for passing fake money in October. Lawmen arrested Tubbs after a prostitute reported to police that she had been paid with bogus money and identified him as the man who gave her the counterfeit bills. Police then discovered that Tubbs, who had only recently moved to Maple Springs in the Indian Territory to practice medicine, and several of his Stone and Searcy County friends who were visiting — and probably doing "business" - in the area had eaten at a restaurant in Fort Smith earlier the same evening, which also reported that it had taken in fake money. When police arrested Tubbs he was carrying seventy counterfeit bills. By the time he appeared in court several weeks later, U.S. prosecutors had charged Tubbs with a total of five counts of counterfeiting, linking his activities from the Indian Territory and the city of Fort Smith to his native Ozarks region—and even a few individuals in eastern Arkansas and Memphis, Tennessee. ${ }^{46}$

Authorities also arrested Lit Dodson, who had accompanied several other local Ozarkers to the Indian Territory and Fort Smith, a few days later when he stopped by to visit his friend Tubbs in the jail at Fort Smith. Dodson, in fact, was taken into custody just after he returned to Fort Smith from making a quick trip back to Alco in Searcy County to marry his late brother Joe's young widow, Alice Kerley Dodson. Authorities later discovered that Dodson had picked up $\$ 3,000$ in counterfeit bills from some undisclosed partner in the Indian Territory before he,

${ }^{46}$ U.S. v. John F. Tubbs, U.S. District Court, Western District of Arkansas, 1897, Jacket no. 414, Fort Smith, Arkansas, Criminal Case Files, 1866-1900 [online database] (Provo, UT: Ancestry.com Operations, 2012). 
Tubbs, and several others headed to Fort Smith for a night out in the city. Dodson was tried by federal prosecutors and convicted in a separate case. ${ }^{47}$

At Tubbs's trial, the defense pleaded his innocence and insisted that authorities had gotten the wrong man. The defense argued that Tubbs had had no idea that the large roll of bills that were on him when he was arrested consisted of counterfeit money. His father, B.R. Tubbs, a prominent physician and merchant from Stone County, testified that his son had been working in his store at Timbo the day before he left for the Indian Territory and Fort Smith when "some cattle trader" came in and purchased several items. At the end of the day, the store owner said that he paid his son for his labor with the bills the cattle trader had passed, which, the defense suggested, turned out to be some of those in Tubbs's possession when he was arrested. Besides, the recent exchange of counterfeit money in the local economy that area merchants and citizens had been reporting during the previous months could easily explain why Tubbs was carrying bad bills, but the defense insisted that he did not know it. ${ }^{48}$

As for the Fort Smith restaurant, Tubbs claimed that his friend, Lit Dodson, in fact, had bought his and several of their friends' suppers that night, so the bad money must have come from him. Dodson - who the court had already found guilty of counterfeiting charges by Tubbs's trial—must have been the one who passed the counterfeit bills at the restaurant, the defense argued. This whole mix-up between Tubbs and Dodson could probably also explain the prostitute's accusations, it suggested. Dodson and Tubbs, after all, were about the same age and bore similar physical characteristics, and they just happened to be wearing shirts that looked

\footnotetext{
47 "Is Lit One of Them"; "The Counterfeiters," Mountain Wave, November 19, 1897; U.S. v. Lit Dodson, U.S. District Court, Western District of Arkansas, 1897, Jacket no. 289, Fort Smith, Arkansas, Criminal Case Files, 1866-1900 [online database] (Provo, UT: Ancestry.com Operations, 2012).

${ }^{48}$ U.S. v. John F. Tubbs.
} 
alike that evening. So, maybe the prostitute had confused Tubbs for Dodson, the defense team argued. In fact, it claimed that it had two witnesses who could testify that they overheard the prostitute say it was possible that she had mistakenly identified Tubbs to authorities as the man who slept with her and paid her with phony cash. The defense, furthermore, called several of Tubbs's friends to testify that he had been with them all night in Fort Smith and that the happilymarried and respectable man never visited a prostitute that evening. The defense's arguments, however, did not convince the jury. Both Tubbs and Dodson received five-year sentences in the federal penitentiary at Fort Leavenworth, Kansas, and Dodson was slapped with an additional $\$ 1,000$ fine. $^{49}$

It is unclear whether or not U.S. Deputy Marshal Joe Dodson was in any way immediately involved in his brother Lit's or other locals' counterfeiting activities. Rumors circulated that Lit may have obtained insider knowledge from his brother about the U.S. Marshals Service's plans and activities in the region, though Searcy County's Mountain Wave outright dismissed such speculations as untrue. ${ }^{50}$ Neither did federal prosecutors point to corrupt connections involving Joe Dodson during Lit's or John Tubbs's trials, though it is possible that, even if suspicions did arise, they saw no reason to open such a can of worms. It is also unknown whether or not Harve Bruce or any of his distilling partners had direct ties to the Bullfrog Valley counterfeiters, but it is certainly possible — and probable — that some operating in the same locale did. Whatever the case, the prevalence of moonshining and counterfeiting in this mountainous area were interconnected, at the very least, in the sense that both of these illicit activities

\footnotetext{
${ }^{49}$ Ibid.; U.S. v. Lit Dodson.

50 "The Counterfeiters."
} 
flourished within an opportunity-strapped environment in an economic periphery created by American industrialization.

The excitement surrounding the counterfeiting and moonshining activities in this area of the Ozarks during the summer of 1897 spurred lawmen and concerned local elites such as Benjamin Franklin Taylor and Joe Dodson to escalate their efforts to suppress illicit economic activities in the region. Marshals Taylor and Dodson met at Snowball in Searcy County on late Saturday morning, August 28, 1897, to assemble a posse and begin heading southward in their search for stills and distillers. Jim Kerley, Dodson's father-in-law and a friend of Taylor's, and Clay Renfroe of Searcy County and S.B. Lawrence of Stone, who were each offered $\$ 10$ a piece per captured still for their assistance, joined the officers' posse. The two marshals picked up another posseman, E.P. Schoolcraft, as they passed en route through Witts Spring. Just as John Burris and deputy revenuer J.P. King had done weeks earlier to help track down Harve Bruce's distillery in Van Buren County, Taylor and Dodson enlisted the help of Tom Barnes—who had also worked some for Taylor in the past—and he too joined the posse later that evening. After nightfall, they crossed into Pope County and hid their wagon in the bushes, as Barnes guided them near the farm of moonshiner Dave Milsap. ${ }^{51}$

Barnes had informed the marshals that Harve Bruce, Turner Skidmore, and perhaps some other local moonshiners who had been on the run in recent weeks were now hiding out and doing business with Dave Milsap and Alva Church at their distillery in northeastern Pope County. Barnes, a longtime customer, employee, and friend of the local moonshiners, in fact, had been to see Milsap and Church at Milsap's farm on Friday night, where he also found Bruce and

${ }^{51}$ Bruce v. State, Transcript of Testimony, 14, 28-29, 36, 42, 47, 107-108. 
Skidmore. According to Barnes, he placed an order for eight or ten gallons of liquor and told them that his brother would bring by some hops. The moonshiners agreed to have it ready for him by Monday. Milsap, Bruce, Bruce's brother Alford, and Skidmore stayed the night at the still—which they had begun operating only about three weeks before—and resumed their liquor manufacturing the next morning. Now that Barnes had discovered the approximate location of their still, he reported the moonshiners to Taylor at Snowball, eager to collect the officer's reward money, now set at $\$ 50$. Barnes agreed to show Taylor and his men the approximate whereabouts of the distillery so long as he did not have to accompany the lawmen when they made their raid, warning the officers that Bruce was "a dangerous man" and "would hunt a fellow." After taking them to the Milsap place, he left the posse and headed back to Searcy County. ${ }^{52}$

Before daylight the next morning, Taylor, Dodson, and their posse slipped through the woods until they were in view of Milsap's farmhouse. Hidden in the brush, they waited and watched for a while but soon decided that the moonshiners were not at the house. The possemen descended back down the wooded hill to begin searching the rough terrain for the still. Marshals Taylor and Dodson left the rest of the posse at the edge of a field while they scouted for the distillery along a nearby creek. While they were gone, the other possemen heard some men chopping wood and talking in the distance. Realizing that it was the moonshiners working at their still, the posse devised a strategy for a raid when Taylor and Dodson returned and proceeded toward the hillside across the farm. ${ }^{53}$

\footnotetext{
${ }^{52}$ Ibid., 47, 51, 53; "Will be Avenged."

${ }^{53}$ Bruce v. State, Transcript of Testimony, 15, 30.
} 
Over at the still, Milsap, who had come out at sunup to check on the still site, began firing up the distillery for another day's production. Bruce and Church were also there, having stayed out in the woods nearby during the night. Milsap agreed to tend to the still while the other two went to eat breakfast at Church's house about a quarter of a mile away. When Bruce made it back to the still a little while later, Milsap took his break from breakfast and headed back home to eat with his family. Church arrived back to join Bruce at the still a short while later. ${ }^{54}$

Meanwhile, Taylor, Dodson, and their posse quietly snuck up the hill to a point where they could see Bruce and Church about fifty yards away sitting on a fence that kept the freerange hogs and cattle away from the still. Hunkering down, the possemen crawled a bit closer to make their move. Once in position, they sprang into a charge with their guns raised and Officer Taylor purportedly yelling at the moonshiners to "Hold up!" What happened next was disputed by each side during the subsequent trial. The surviving possemen testified that the moonshiners fired the first shot, while Bruce and Church contended that the raiding lawmen were the first ones to discharge their weapons. In this case, Bruce and Church probably told the truth. A county sheriff's deputy, the local justice of the peace, and other witnesses testified during the trial that posseman S.B. Lawrence admitted to them in his initial statements after the shooting that he fired the first shot into the air in hopes of stopping one of the moonshiners who was

\footnotetext{
${ }^{54}$ Ibid., 109-110, 117, 130. Bruce maintained throughout his trial that he had no direct monetary interest in this particular still, insisting that it belonged only to Milsap and Church. He explained that he was only visiting his friends while hiding out from John Burris and the federal officers and that he had gone there to seek medical treatment for a cough from Dr. Church, Alva's father, who lived nearby. Milsap and Church supported his claim, though some witnesses testified that they knew Bruce, Milsap, and Church to be partners in the liquor business. The prosecution suggested that Bruce, Milsap, and Church had conspired to cover up Bruce's involvement in the distillery while serving time together at the federal prison in Fort Leavenworth, Kansas, before the murder trial began, probably because Bruce was already wanted on other charges and had agreed to take the rap for all of the shooting. Indeed, one might speculate that since Bruce and Skidmore had shut down their own distillery in Van Buren County when Burris and federal officers discovered their operation during the preceding weeks, they may well have formed a partnership and consolidated their markets with their longtime friends who remained hidden from authorities and continued to do business over in Pope County. See pages 107, 117, 1128-129, 143, 154-155.
} 
trying to run away down the backside of the hill. Several other witnesses also testified that one or more of the surviving possemen had told them that they shot first, including a preacher who claimed that posseman Clay Renfroe confessed to him at a gospel meeting in Searcy County a few weeks after the shooting that he and the other lawmen had "done a bad work." 55

Bruce later confessed that he was the only moonshiner who did any shooting from the still. He claimed that Church had quickly bolted away and escaped when he saw the possemen emerge from the brush at the bottom of the hill, though the possemen swore that Church fired at them too as he hurried away. Sitting nearer to the charging possemen and with his back initially turned toward them, Bruce explained that he, unlike Church, had no chance to escape. Fearing for his life, he darted toward his .40-60 Winchester and positioned himself behind some bushes to return fire. With bullets striking all around him—one of which hit him in the leg—Bruce shot Dodson in the head, killing him instantly, and hit Taylor in the abdomen. Taylor staggered back down the hill and out of sight before collapsing. A bullet also pierced Clay Renfroe in the side, and he and Jim Kerley evacuated the open hillside. According to Bruce, the shooting ceased for a few seconds, and he prepared to make a run for it. But Bruce then noticed another man, S.B. Lawrence, lying beneath some bushes, his muzzle aimed straight at him. Bruce quickly wheeled his rifle around and shot, just as Lawrence blasted toward him. The posseman missed Bruce, but the moonshiner's bullet tore most of Lawrence's left arm from his body. Lawrence retreated down the hill to where fellow posseman E.P. Schoolcraft sat nursing the dying Taylor. Schoolcraft helped Lawrence remove his jacket to assess what was left of his mangled arm, and,

${ }^{55}$ Ibid., 64, 68, 75, 82-83, 85-87, 90-92. 
after Taylor took his last breath, they and the other two possemen scurried through the woods to a nearby farmhouse to report the incident and call for medical attention. ${ }^{56}$

Soon after the possemen arrived at the Walker house and reported the shooting, local lawmen arrived to take their statements, and a doctor came from Pottsville to finish amputating Lawrence's maimed arm. News of the deadly affair spread like wildfire throughout the surrounding areas, and local and federal lawmen, as well as dozens of concerned citizens and curious onlookers, flocked to the scene, where the bodies of Taylor and Dodson were carried away. Enraged friends and members of the Taylor and Dodson families also made their way into the mountains of Pope County, vowing to avenge their deaths. A letter written by a citizen of Marshall to Little Rock's Arkansas Gazette the next day explained that a number of Searcy Countians were "in a high fever of excitement and in case the guilty parties are captured, Judge Lynch will probably take a hand." Marshall's postmaster, M.A. Sanders, echoed such predictions, writing to the U.S. Marshals Office that "[a]ll good citizens here are turning out to assist the officers to catch the murderers and if, under the present excitement, any of them are caught, my opinion is they will be hung without ceremony."

After the shooting, Bruce had hurried ten miles east to his farm in Van Buren County and stopped by his house just long enough to clean the bullet wound in his leg, shave his burly beard, and grab some food before heading deep into the wooded mountains to hide out. A few days later, Bruce went south to the towns of Springfield and Conway in the Arkansas River Valley

\footnotetext{
${ }^{56}$ Ibid., 34, 37-38, 118, 131-132. A transcript of Bruce's testimony was also printed Russelville's CourierDemocrat. "Involuntary Manslaughter," Courier-Democrat, November 23, 1899.

${ }^{57}$ Ibid., 64, 66, 68; "Will be Avenged”; “Ki Marcum,” Arkansas Gazette, September 1, 1897. Some observers erroneously assumed at first that another local moonshiner, Ki Marcum, was responsible for the killing of Taylor and Dodson.
} 
and then to the city of Little Rock, before traveling east of the Mississippi River. He stayed in Alabama for the next ten months, where he lived with and worked for a man named Sol Long. From there, he secretly corresponded with his wife and children and sent them money through his trusted brother-in-law who lived in the Indian Territory. ${ }^{58}$

It did not take long for federal officers to pinpoint Bruce as one of the key murder suspects, and Deputy Revenuer J.P. King, who had diligently searched for the stubborn old moonshiner since his and Burris's close encounter with him several weeks earlier, led a party of officers to the Bruce farm in Van Buren County a few days after the shooting. Though they did not find Bruce himself, King and his men finally located and destroyed his and Skidmore's distilling equipment. Convincing Bruce's wife to show them where her husband had hidden the still, King promised to pay her the government's $\$ 10$ reward and probably threatened her with charges of criminal accessory in the murder case if she did not. According to a resentful Bruce, however, King never followed through with his promise to pay his wife the bounty. During the trial, Bruce denounced King for such deceit, telling the court that if the federal officer "was a gentleman he would pay it." 59

Alva Church had bolted away and ran to his house when the shooting began. Finding no one home, he then went to his parents' place nearby before going to hide out in the woods. His wife had heard the gunshots from their house and hurried toward the still to see what had happened. On the way there, she met a neighbor, Smith Pack, who had also heard the commotion, and the two of them went together to the still site where they found Taylor and

\footnotetext{
${ }^{58}$ Bruce v. State, Transcript of Testimony, 132-133.

${ }^{59}$ Ibid., 141.
} 
Dodson lying dead. She then rushed over to the Milsap farm to tell Dave and his family what had happened. Knowing that the law would soon be on his trail too, Milsap also went into hiding. Indeed, a search posse came by the Milsap house that evening and stayed the night there. When word of the shooting got around to Turner Skidmore and Bruce's brother, Alford, they too set out for the woods. ${ }^{60}$

Milsap and Church met in the woods and stayed hidden during the night. The next morning, however, they decided to go to the authorities to tell them what had happened, probably hoping to clear themselves of the murder charges that were sure to come. Nonetheless, they were arrested, convicted of illicit distilling by a federal jury, and sentenced to three years in the penitentiary at Fort Leavenworth, Kansas. Charges were then filed against them for the murder of Taylor and Dodson, and the McKinley administration commuted their sentences at Fort Leavenworth after twenty months so that they could go stand trial in Pope County in the fall of $1899 .^{61}$

In the days following the shooting, federal, state, and local lawmen combed the mountains in search of other suspects and stills, making good on the U.S. Justice Department's promise to "wage war to the knife against the devotees of illicit distilling in Arkansas." The Arkansas Gazette predicted that, “[w]hen Uncle Sam gets after the 'shiners in dead earnest, it may be reasonably expected that illicit distilling will receive its death knell in Arkansas." Authorities made a big catch on September 2 when they apprehended John Church, a relative of

\footnotetext{
${ }^{60}$ Ibid., 102-103,

${ }^{61}$ Ibid., 110-112; "Moonshiners' Sentence," Mountain Wave, November 26, 1897; Annual Report of the Attorney General of the United States, 1899 (Washington, D.C.: Government Printing Office, 1899), 290.
} 
Alva and a fellow moonshiner, who agreed to turn state's witness in exchange for immunity. ${ }^{62}$ Two days later, deputy marshals arrested four others on moonshining charges and suspicion of involvement in the Taylor and Dodson killings. ${ }^{63}$

Amid the excitement and anxiety of the ongoing investigation and dramatic hunts for suspects and stills in the area during the subsequent weeks and months, local, state, and national newspapers closely followed the case's developments and eagerly reported the many rumors and conspiracy theories that sprang forth as authorities gradually unearthed bits and shards of the puzzle. Rumors abounded that perhaps dozens of local moonshiners had conspired to assassinate the marshals and their posse when officials discovered that two area moonshiners, both of whom were also U.S. postmasters in their respective small communities, had written strange letters only a few days before the tragic shooting in late August to some of their distilling partners who had already been arrested and were being held in the state prison at Little Rock. These peculiar letters, which were intercepted by prison guards, stated that "there will be an earthquake in England on the $28^{\text {th }}$." After the deadly shooting on August 29, officials arrested the individuals and investigated the suspicious matter. They eventually concluded that the writers were merely members of a strange spiritual group based in Springfield, Missouri, and that their curious letters referred to some of their premillenialist predictions about the End Times. The frustrated editor of Searcy County's Mountain Wave, however, demanded that officials reopen a more thorough investigation of the letters and their possible connection to the deaths of Taylor and Dodson,

\footnotetext{
62 "Going After 'Em,” Arkansas Gazette, September 3, 1897.
}

63 "Captured Four," ibid., September 5, 1897. 
arguing that, even though the shootout had occurred on the $29^{\text {th }}$ instead of the $28^{\text {th }}$, their religious explanation was simply too "ghostlike" to accept. ${ }^{64}$

Though the Wave's suspicions about the strange letters never amounted to anything, other observers, such as the New York Times, were also quick to speculate about a broader conspiracy concocted by numerous anti-government mountain denizens, their families, and communities. The New York Times, in fact, ran an article in September and two more in December that linked other tragedies in the area to the violent, lawless moonshiner and the tragedy in Pope County. On September 18, the paper reported in an article, titled "A Dying Man Denied Water: Friends of Arkansas Outlaws Ill Treat Deputy Marshals," that local residents—supposedly in cahoots with the Bruce gang and other area moonshiners - had refused to give water to a government search party on a scorching hot day and in a few cases even rudely chased them from their properties, causing one posseman from Searcy County to die of heat exhaustion. Keeping a watchful eye for exciting new developments in the Ozarks moonshining case, the New York Times ran another article in early December in which it reported that an old friend of Taylor's and a fellow opponent of area moonshiners, Albert Giles, was assassinated from ambush by unknown vengeance-filled moonshiners tied to Bruce and a vast Ozarks whiskey ring. Less than two weeks later, the paper ran another story, titled "Arkansas Family Butchered," and told of the horrendous massacre and robbery of the prominent Patterson family in their home on Culpepper Mountain in Van Buren County. "One theory advanced for the murder," the New York Times loosely speculated, "is that it is the work of moonshiners, who infest this section, as Patterson

64 "Like a Romance," Mountain Wave, September 24, 1897. 
was hated by all of them" because he had "giv[en] the authorities information that led to the arrest and destruction of numerous illicit distilleries in the county."65

Despite the New York Times's attempts to tie these subsequent Ozarks tragedies to the Pope County shooting and local moonshiners, local papers and government officials apparently never made the same connections in their investigations and reports. Streamlining these sensational stories from the August shootout in Pope County, nevertheless, made for some good yellow journalism and helped further impress the stereotypes of an inherently backward, violent, and authority-defying mountain culture into the national consciousness.

Though some observers tended to over-speculate and embellish, there is little question that all of the hype surrounding the massive searches and authorities' elevated determination to crack down on illicit distilling in the aftermath of the deadly incident in Pope County fueled a heightened sense of suspicion and distrust in the region. In the weeks following the killings of Taylor and Dodson, the federal government created new law enforcement positions to increase patrols and searches throughout the region, most of which were filled by prominent and wellconnected locals. Little Rock's office of the Internal Revenue Service quickly commissioned John Burris with an official government position as a raiding deputy collector after the shooting, "which clothed him with power to destroy wild-cat stills in any part of the state." 66 IRS officials also appointed Taylor's son-in-law, W.P. Hodges, as a deputy collector, “clear[ing] the way for him to hunt down the perpetrators of the crime with all the powerful machinery of the

\footnotetext{
65 “A Dying Man Denied Water,” New York Times, September 18, 1897; "Revenue Informer Killed,” ibid., December 7, 1897; “Arkansas Family Butchered,” ibid., December 18, 1897.

${ }^{66}$ Stapleton, Moonshiners in Arkansas, 4.
} 
government to aid him," and enlisted the help of dozens of other locals, either with permanent law enforcement positions or reward money ${ }^{67}$

With armies of federal and local officers combing the area's farms and forests, with a sizeable pot of reward money in-hand to entice cash-starved local residents to help them, hill farmers who were engaged in the moonshining business began to think twice about their friends and neighbors. They clung evermore tightly to those they could trust, and at times retaliated against those who "turned traitor." Information handed over to authorities by a twenty-threeyear-old northern Pope County farmer and moonshiner, John Vaughan, led to the arrests of a major band of illicit distillers in the Arkansas River Valley several miles to the south, including some "negro" moonshiners in Conway County, though authorities apparently never directly linked them with the Bruce gang. Several days later, Vaughan's dead body was found lying in the road near Appleton, "supposed[ly]...bushwhacked by the moonshiners" who feared he would spill more of the beans about the area's "whiskey business." ${ }^{, 68}$ In late October the federal grand jury of Arkansas's western district filed a report, describing the elevated sense of anxiety, distrust, and even terror that seemed to have swept over the region:

We find the unlawful manufacture and sale of whiskey enormous, and apparently on the increase. It is almost impossible to get testimony in these [illegal liquor] cases: witnesses will evade answering questions, incriminate themselves before they will answer truthfully, and will plead guilty to have committed the offense

\footnotetext{
${ }^{67}$ Mountain Wave, September 24, 1897.

68 "Shot Through the Heart," Arkansas Gazette, October 7, 1897.
} 
themselves in order to save large numbers charged, and who are guilty beyond doubt. ${ }^{69}$

Acts of intimidation by some moonshiners persisted in certain places for at least another year, according to some anti-liquor proponents. In October 1898, a key witness for federal prosecutors against a number of Cleburne County moonshiners claimed to have borne the wrath of angry nightriders who slaughtered his livestock and dogs, torched his barn and other property to the ground, and warned him and his family to "get out of the country right away., 70

Officers continued to make some big arrests and successful raids during the weeks and months following the shootout at the Milsap farm in August 1897, including one in Pope County in which authorities destroyed a 100-gallon still and 1,000 gallons of mash. ${ }^{71}$ A big arrest in connection with the deaths of Taylor and Dodson came when authorities captured Harve Bruce's brother, Alford, near the cities of Fort Smith and Van Buren in mid-September. ${ }^{72}$ By the first of October, with Church and Milsap already in custody, investigators had narrowed down their key suspects to Harve Bruce and Turner Skidmore. Federal and state authorities, along with members of the Taylor family, issued to the public a combined $\$ 1,000$ reward for their capturedead or alive. ${ }^{73}$

\footnotetext{
69 "They Protect Each Other," Russellville Democrat, October 21, 1897.

70 "Moonshiners in Arkansas," New York Times, October 30, 1898.

71 "A Raid," Russellville Democrat, November 4, 1897. For other noteworthy raids in the area and elsewhere in the Arkansas uplands, see "Destroyed Two Stills," ibid., October 21, 1897; "Whiskey Peddler Arrested," Arkansas Gazette, October 10, 1897; Stapleton, Moonshiners in Arkansas, 5-28.

${ }^{72}$ Russellville Democrat, September 16, 1897.

73 "Bruce and Skidmore," Arkansas Gazette, October 2, 1897.
} 
In late November, after finding out that Skidmore had just arrived back at his home on Oak Mountain in Van Buren County after a long stay in the Indian Territory, the local sheriff and one of his deputies snuck to his farm to arrest him. Skidmore put up no resistance, and the sheriff quickly escorted him to the state prison in Little Rock for safe-keeping, arriving, coincidentally, at approximately the same time that a federal judge handed down prison sentences to Church and Milsap for illicit distilling in violation of internal revenue laws. Skidmore, who denied having been within ten miles of Milsap's farm on the day of the shooting — though Searcy County's Mountain Wave confidently reported "that enough evidence will be produced to hang him"- pleaded guilty to illicit distilling charges and was sent to join Church and Milsap at the federal penitentiary in Fort Leavenworth. ${ }^{74}$ Bruce, however, remained at large, and frustrated authorities continued their pursuit with very few leads.

Federal officers worked tirelessly and expended enormous amounts of resources in their search for Bruce and other moonshiners in the area during the subsequent winter, spring, and summer. By the fall of 1898, Burris and other federal authorities had busted up several large distilleries in the region, including a noteworthy raid in Polk County in the Ouachita Mountains of southwestern Arkansas. Burris and his men captured one of the still's operators by pistolwhipping him into submission, but three of his partners escaped. A determined Burris, however, immediately "got busy" and tracked down and arrested one of the moonshiners near Spokane, Washington, apprehended another in Duluth, Idaho, and the third finally surrendered to lawmen at Conway in Faulkner County. Burris's ambitious efforts—or at least his heavy expenditure of federal funds to conduct these efforts — during the summer and fall of 1898, however, raised

\footnotetext{
74 “Turner Skidmore Arrested,” Mountain Wave, November 26, 1897; "Moonshiners' Sentence.”
} 
some suspicion among IRS officials in Washington, D.C. Inspector A.C. Patterson reported back to the IRS after a visit to the Ozarks during the summer and fall of 1898 that his preliminary investigation discovered irregularities in Burris's expense accounts, in addition to some questionable conduct by other deputy collectors in the region. Patterson's report prompted a full investigation by the IRS's chief of revenue agents over the following months, though it ultimately "exonerated" Burris and the other Ozarks officials from any disciplinary measures. ${ }^{75}$

Federal and local lawmen finally caught their break in the Taylor and Dodson case in early October 1898. During one of Harve Bruce's brief visits to his home on Oak Mountain from Alabama, J.W. Gist, a neighbor and cattle buyer, discovered that the "outlaw" was back at his Van Buren County farm. Determined to collect the large pot of reward money, Gist grabbed his rifle and carefully snuck his way onto his neighbor's farm where he observed Bruce working at his barn all afternoon from the thick cover of the woods. After nightfall, when Bruce returned to his house, Gist quietly slipped closer until he could see through the windows. Waiting until Bruce went into a bedroom — a safe distance away from his "trusty Winchester"—Gist stormed into the house and arrested the old moonshiner at gunpoint. Gist escorted Bruce to Conway, where local police took him into custody and then transferred him to federal authorities in Little Rock. Convicted of illicit distilling by a federal court during its fall term only a few weeks later, Bruce was sentenced to federal prison in Fort Leavenworth, where he soon joined Church, Milsap, and Skidmore. ${ }^{76}$

\footnotetext{
${ }_{76}^{75}$ Stapleton, Moonshiners in Arkansas, 36-37.

76 "Got Harve Bruce," Courier-Democrat, October 7, 1898; "Bruce Captured," Mountain Wave, October 7, 1898; Bruce v. State, Transcript of Testimony, 138.
} 
Not long after Bruce's arrest, the local prosecuting attorney and the circuit court judge in Pope County quickly made preparations for the moonshiners' trial in the Taylor and Dodson case, hoping to begin during the next court session in the spring of 1899. But when local officials requested that the federal government transfer Bruce and the others to Pope County to stand trial, the U.S. Attorney General's office regretfully informed them that it "has no power to interfere with the sentence of the federal court," which they were currently serving at Fort Leavenworth on moonshining convictions, and, thus, could not at the present time hand them over. The disappointed and rather disgusted Courier-Democrat in Russellville lamented the Attorney General's decision, "because quite a large amount of costs has already accrued in preparing for the trial." In late May, however, the McKinley administration arranged to have the federal sentences commuted, "only for the purpose," wrote the attorney general, "of having them turned over to the State authorities for prosecution for a higher crime., ${ }^{, 77}$

Observers, both locally and throughout the state, eagerly anticipated the high-profiled murder trial, now set to begin during the court's fall term. State attorney Lawrence Russell, U.S. attorney C.C. Waters, and Taylor-family attorney J.T. Bullock headed the prosecution, while Col. G.W. Bruce (probably an extended relative of Harve Bruce) of Conway and J.A. Gillette of Atkins prepared the defense. Interestingly, state attorney general — and soon to be governorJeff Davis's private law firm, Davis \& Son of Russellville, also assisted with Bruce's and the other moonshiners' defense, though the "Tribune of Haybinders" himself was busy at the moment using his public office to file anti-trust suits against "every fire insurance company doing business in the state"-much like "Jesus Christ whipped just such a gang of fellows out of

77 "State vs Bruce at al.," Courier-Democrat, March 30, 1899; Annual Report of the Attorney General, 1899, 290291. 
the temple," as he described it. After the fall term finally opened and the Pope County Circuit Court disposed of its less dramatic cases, Judge William L. Moose commenced the trial and proceeded slowly and carefully with jury selection in early November. ${ }^{78}$

"No case that has been tried here for many years has attracted the attention of this one," Russellville's Courier-Democrat noted. It and other area and state newspapers, reflecting the "unusual interest [in] the case," reported on the "thrilling evidence" unearthed during the trial by the examinations of "[n]early one hundred witnesses," the "most dramatic" coming when Harve Bruce himself took the stand. Although Bruce came to court clean-shaven-which likely disappointed a number of urban, middle-class reporters who were hungry for an ultrasensational, picture-perfect mountain drama-Little Rock's Arkansas Gazette described the now infamous moonshiner as "a typical mountaineer in build and character, being strong, athletic and said to be absolutely fearless and is an unerring marksman," notorious for his legendary hunting skills. $^{79}$

Standing 6' 2" and weighing about 190 pounds, the gray-headed, fifty-five year-old Bruce, who was said to have been known for his "quick spoken[ess]," calmly took the stand. Never flinching as the prosecutors grilled him with tough questions and accusations, Bruce stood ready with quick and direct responses, his pale blue eyes staring straight into theirs without any appearance of nervousness or intimidation. Admitting that he had been manufacturing illegal whiskey and eluding authorities when the deadly shootout occurred, Bruce took full-blame for

\footnotetext{
78 “Involuntary Manslaughter,” Courier-Democrat, November 23, 1899; “Circuit Court,” ibid., November 16, 1899 ; Raymond O. Arsenault, "Jeff Davis (1862-1913)," Encyclopedia of Arkansas History and Culture (http://www.encyclopediaofarkansas.net/encyclopedia/entry-detail.aspx?entryID=98\#); Arsenault, Wild Ass of the Ozarks, 70.

79 “Involuntary Manslaughter”; “Acquittal of Millsaps,” Mountain Wave, November 18, 1899; Quotation from Arkansas Gazette in "Involuntary Manslaughter."
} 
doing all of the shooting at Taylor, Dodson, and the other officers at the still that day, but he insisted that he did so only in self-defense. When asked by prosecutors why he fired upon the officers, Bruce candidly responded: "I shot to hurt for I saw no other way to save my life," explaining that Taylor and his men never properly identified themselves as lawmen and shot at Church and him first. ${ }^{80}$

After hearing the closing arguments and receiving instructions from Judge Moose on Friday, November 17, the jury deliberated for the next five days. Much to the disappointment of prosecutors, the Taylor and Dodson families, and others who prayed for a first-degree murder conviction, the jury found Bruce guilty of involuntary manslaughter and set his sentence at six months in the state prison in Little Rock. "Bruce's statements on the witness stand," explained the Courier-Democrat, "made a strong impression on the jury..." 81 The defense, nevertheless, to the surprise of many, proved unsatisfied with the verdict and appealed the circuit court's decision to the Arkansas Supreme Court. On Thursday afternoon, November 23, the state's Supreme Court notified Judge Moose that it had accepted Bruce’s appeal, and his bond was set at \$4,000. The Russellville paper reported the case's new development in its Thanksgiving Day issue:

As soon as the necessary papers were properly executed and delivered, this old man accompanied by as true and loyal a wife as ever clung to man in his hours of trial and tribulations, passed...upon the streets and having received the congratulations of many friends, entered a covered wagon and departed for his home amid the tall pines, stately oaks and towering cliffs of the Boston

\footnotetext{
80 "Bruce and Skidmore"; "Involuntary Manslaughter"; Bruce v. State, Transcript of Testimony, 132.

81 "Involuntary Manslaughter"
} 
mountains, there no doubt to await with more or less anxiety the report of those who shall pass judgment as to what shall be the closing chapter of this most unfortunate and ever deplorable period of his life. ${ }^{82}$

Hoping that the Arkansas Supreme Court would see fit to overturn the Pope County Circuit Court's ruling, Bruce and his family patiently waited for word from Little Rock, which they finally received in late June of 1900 . Unfortunately for them, the state's high court affirmed the ruling. In writing the court's opinion, Justice J. Battle even went so far as to say that "[t]he verdict of the jury is remarkable... They were unreasonably lenient to him, and he has no right to complain." With his appeal for acquittal rejected by the Arkansas Supreme Court, Bruce left for Little Rock to serve his six-month prison term. Soon after his arrival, Superintendent Bud McConnell assigned Bruce to guard duty, purportedly telling him that since "he could use a Winchester so desterously [sic] on marshals he would make a good guard.” Luckily for Bruce, however, he had made some important connections that shortened his stay at the state prison. The owner of the Russellville law firm that had helped defend him at his trial now occupied the state's chief executive office in Little Rock, and Governor Jeff Davis included Bruce when he issued an unprecedented number of pardons after his inauguration in January 1901. "A Karl Marx for Hillbillies," as the Arkansas-born southern sociologist Rupert Vance characterized him, Davis later defended his controversial pardoning record against critics in typical populist fashion,

\footnotetext{
82 "Bruce Out on Bail," Courier-Democrat, November 30, 1899.
} 
arguing that at least he had "pardoned people while [the conservative state supreme court's] Judge Wood pardoned the railroads. ${ }^{, 83}$

Not long after Bruce arrived in Little Rock to serve his time in the state prison, a reporter from the Conway Democrat paid a visit to Harve Bruce, now "[o]ne of the most noted characters in the penitentiary." The reporter depicted Bruce as "a typical old mountaineer and moonshine distiller" who had once "wore long flowing whiskers, which made him look about as we imagine Moses did about the time he delivered the law of the 'Children of Israel.'” Assessing Bruce's resistance and attitude through the lens of typical hillbilly stereotypes, the reporter claimed that "[t]he mountaineer hates the marshals and the government that try to prevent him from doing with his corn as he pleases. He thinks he has as much right to make whiskey out of it as bread." $" 84$

Bruce's own explanation, however, pointed to practical economic necessities in the rural Ozarks rather than some anti-government hill culture and knee-jerk reaction against authorities telling him what he could and could not do. When asked by the Conway newspaper reporter why he and his Ozarks neighbors flaunted the federal and state laws against making moonshine, "Bruce explained that their corn was worth only 30 cents per bushel. When they made it into whiskey the slop was worth as much as the corn to feed the hogs and they could get $\$ 2.00$ per gallon for the whiskey. This was the only way, he explained, of getting any money up there in the mountains." It was, they believed, their best chance of fulfilling the American Dream amid limited opportunities in the rural Ozarks. Nevertheless, because of the unfortunate ruckus that

\footnotetext{
${ }^{83}$ Bruce v. State, Opinion of the Supreme Court of Arkansas, June 23, 1900, 68 Ark. 310; "Arkansas Penitentiary," Conway Democrat, August 17, 1900; Rupert Vance, “A Karl Marx for Hill Billies," Social Forces 9 (December 1930): 180-190; Davis quoted in Arsenault, The Wild Ass of the Ozarks, 192.

84 "Arkansas Penitentiary."
} 
had left two men dead and landed him in the slammer, Bruce, according to the reporter, promised "that he would not distill any more whiskey as he wanted to live in peace now." After his discharge from the state prison, Bruce returned home to Oak Mountain where he "lived the life of a respected and honored citizen" until he died a few years later in March of $1907 .{ }^{85}$

While contemporaries such as the Conway Democrat reporter-and most popular accounts since then—assumed that mountain moonshiners' defiance of liquor laws stemmed from a unique backwoods hill culture that automatically rejected any and all government interference, Bruce's particular ideas and attitudes about the proper role of government are difficult to pin down. Like most rural commoners, Bruce left behind very little in the historical record. Important clues do exist, however, that tend to suggest that he, like most of his neighbors in small farm communities across the Ozarks, shared the typical rural American workingman's populist conviction which "yearn[ed] for a society run by and for ordinary people who lead virtuous lives," whether or not that meant more or less government in a particular circumstance, and not some "ancestral dread of federal power." 86

Bruce likely supported and voted the Democratic ticket in most elections. When his third son was born on July 12, 1887, he and his wife named him Grover Cleveland Bruce, probably after the sitting Democratic president. While President Cleveland would eventually go down in history as a defender of "the old gospel of laissez-faire...[and] an order dominated by big business," his conservative legacy was not established until his second term in office from 18931897 amid the watershed insurgency of the Democratic Party's populist wing, led by William

\footnotetext{
${ }^{85}$ Ibid.; Stapleton, Moonshiners in Arkansas, 4; "The Legend of Harve Bruce" (http://oakspringsmountainranch.com/Legend_of_Harve_Bruce.html).

${ }^{86}$ Quotations in Michael Kazin, A Godly Hero: The Life of William Jennings Bryan (New York: Alfred A. Knopf, 2006), 306 and 46, respectively.
} 
Jennings Bryan —-working-class America's "Godly Hero"- that finally put the party of Andrew Jackson "on a course that led away from their laissez-faire past and toward the liberalism of the New Freedom, the New Deal, and the Great Society.” Indeed, as historian Michael Kazin reminds us, President Cleveland "managed to keep his party united" during his first term amid growing fissures between economic conservatives and a rising tide of populist reformers with his appeal to rural family farmers, small businessmen, and urban wage laborers by touting his "antitrust fervor" and opposition to high tariffs that benefitted special interests in the Northeast at the expense of common consumers. Many former Confederate soldiers like Bruce, furthermore, had celebrated Cleveland's election in 1884 as the first Democrat to occupy the White House since before the Civil War and applauded his appointments of southerners to key positions in his administration. ${ }^{87}$

If, in fact, Bruce was a conservative disciple of libertarian laissez-faire ideology, he would have been an anomaly in the rural Ozarks during his time and would have fit in much better among the wealthy planter class of the Delta. During the late nineteenth and early twentieth centuries, populist demands for government-enforced reform spewed from the Arkansas Ozarks, just as they did from other rural regions dominated by small family farmers and laborers. Rural folks called on a government of "the people" to break apart and corral the unjust excesses of free market capitalism by redistributing the wealth and power of big moneyed and special interests to hard-working and God-fearing commoners like themselves. Such sentiments were especially strong in Bruce's section of the rural Ozarks. The Brothers of

\footnotetext{
${ }^{87}$ Draft registration card for Grover Cleveland Bruce in Ancestry.com, World War I Draft Registration Cards, $1917-$ 1918 [database on-line], (Provo, UT: Ancestry.com Operations Inc, 2005); Quotations in Kazin, A Godly Hero, 149, 56 , and 20 , respectively.
} 
Freedom, after all, had counted Van Buren and Pope counties among its most successful organizing campaigns. ${ }^{88}$

The enormous popularity of agrarian Democrat Jeff Davis among rural folks in Harve Bruce's home area in the late 1890s and early 1900s also illuminates how these populistprogressive sentiments about government pervaded politics, society, and culture in the region. But the charismatic governor's political position—or lack thereof — on government alcohol reform, perhaps as well as any other issue, also indicates how a skillful politician such as himself could sometimes manage to play both sides of the fence for votes and tap general populist sentiments that appealed to both poor backcountry folks and more well-to-do rural and their antagonist town elites at the same time.

Davis's ambiguous stance on alcohol regulations during his tenure as governor exemplified his intentionally vague populist persuasion in general. As historian Raymond Arsenault explains, "temperance advocates had reason to believe that the new governor would prove to be a reliable ally," since his father had been a prominent anti-liquor crusader and Davis had served as prosecuting attorney in "the 'driest' judicial district in the state" during the early 1890s. Ever the adept politician, however, Davis realized that his "support was concentrated in the rural areas, particularly in the more isolated farm precincts," but also in those districts with small towns, villages, and better-connected farming communities. With his rural constituency largely split over the alcohol issue in many areas, Davis completely avoided the liquor question in his 1900 gubernatorial campaign. Not long after occupying the governor's office, however, the state legislature put Davis on the spot when it passed the Holt Bill, the temperance leaders'

\footnotetext{
${ }^{88}$ Henningson, "Upland Farmers and Agrarain Protest," 81, 100.
} 
"most important piece" of legislation yet which would have banned all liquor transportation through Arkansas's dry counties. Davis vetoed the bill, arguing that it was "too extreme" and that Arkansas had "the best liquor laws of any state in the Union" without it. Davis's decision undoubtedly set well with backcountry farmer-distillers, but disappointed temperance advocates soon forgave him too and "continued to court the governor's favor." Davis was even elected a few months later as the vice-president of the Arkansas Baptist Association (ABA), "the most temperance-conscious religious organization in the state." 89 His populist magic had worked once again.

The whiskey issue confronted Davis again shortly after his resounding victory in the 1902 Democratic primary, though this time it became quite personal. Davis's political rivals attacked and accused Davis of public drunkenness, forcing his resignation as ABA vice-president in April and prompting his expulsion from the Second Baptist Church of Little Rock in May. But Davis made the damning controversy into yet another opportunity to bolster his populist image as a victim of the state's "high-combed roosters" and asked his fellow Arkansawyers to stand with him against the "pharisees who had persecuted him for his political beliefs." Davis continually "avoided the liquor issue as much as possible in political campaigns" throughout the rest of his career because of the divided mind of his rural constituency. "Like many of his followers," as historian Raymond Arsenault puts it, "Davis played both sides of the street consistently and sincerely." 90

\footnotetext{
${ }^{89}$ Arsenault, Wild Ass of the Ozarks, 148, 154.

${ }^{90}$ Ibid., 158-162.
} 
The dual legacy of the 1897 Pope County affair reflected this divided mind in the rural Ozarks. Local prohibitionists, boosters, and lawmen remembered Taylor and Dodson as martyrs for the principles of "progress" and "law and order" - in their view, virtuous protectors of their communities' overall well-being and quest for prosperity. But the tragic episode also helped confirm more radical populist suspicions about the injustices of privileged-controlled government for a number of the area's dispossessed backcountry folks. Printed in the local Pope County newspaper, Bruce's candidness and convincing testimony at the trial—especially his claims about how Burris and King treated his daughter and wife and then how he described Taylor's and Dodson's reckless conduct in their raid—succeeded in painting the federal officers as unjust aggressors in the eyes of many hill folks. The Courier-Democrat seemed to think so, commenting that Bruce's "apparent sincerity made him many friends." At least some government officials also confirmed such impressions in their own right, without Bruce's help. As Burris and his men scouted and patrolled for moonshiners after the shooting, for instance, they searched a small mountain farm in southeastern Newton County and were confronted by the farmer's wife. Before realizing they were federal authorities looking for stills, she asked them, "Who are you anyhow?" A condescending Burris sarcastically responded, "I am a lady’s man." Infuriated by his arrogance and, in her eyes, haughty abuse of authority, she quipped back: “G__ D__ you. You had better be at home with her instead of riding over the country destroying people's property." 91 While growing numbers of rural Ozarkers-particularly those with better market connections — championed tougher regulations by "the people" against the "whiskey interests," several others — especially in the more remote reaches of the backcountry-

\footnotetext{
91 “Involuntary Manslaughter”; Davis quoted in Arsenault, Wild Ass of the Ozarks, 167.
} 
despised local anti-liquor elites' strong-armed use of government power to enforce conformity to their vision and interests.

The latter legacy of moonshiner-versus-government conflict outlived the former amid the evolution of the rural Ozarks during the twentieth and twenty-first centuries, weaving its way more nicely into the fabric of the region's mythical image and the purposes and tastes of its narrators. Harve Bruce went down in local lore among many rural folks as an Ozarks "legend," the nostalgic epitome of the individualistic mountaineer taking a principled don't-tread-on-me stand against the invasive and abusive arm of government. A folk ballad about Bruce and the fatal moonshine raid, sung to the tune of the popular American folk song "Cindy," passed through subsequent generations in the area into the latter part of the twentieth century:

Old Ben Taylor, he got killed

Trying to capture a wildcat still.

Taylor and Dodson got a lot of men

And thought they'd capture a wildcat den.

They went up and fired their guns

And thought them wildcat's men would run.

Old Harve Bruce, he's dead and gone

Had the best wild cat still around.

Old Harve Bruce raised the alarm

And shot Si Lawrence through the arm.

Old Schoolcraft, warn't no fool

Shot his musket and run like a mule

Alva Church was there too

Shot Joe Dodson through and through.

Old Harve Bruce he done well

Killed Ben Taylor dead as hell. 
Old Harve Bruce never tried

Shot Clay Renfro through the side. ${ }^{92}$

In 1982, the local newspaper, Russellville's Daily Courier-Democrat, featured an article in one of its Sunday editions on "the legend of Harve Bruce" and his exceptional "pioneer" moxie.

Professing that "mountain men have always been noted for their accuracy with a gun," the article recounted Bruce's larger-than-life marksmanship in the story of the deadly 1897 moonshine raid and a couple of tall-tale hunting stories, as told about Bruce by some of his "mountain friends." "According to men who knew him, he had no peer with a rifle," the paper exclaimed, and was known as "a man not to fool with," a real McCoy of mountain folklore and nostalgia. ${ }^{93}$

The romanticized story persisted into the twenty-first century to become a convenient tale for America's anti-government, anti-Obama tea party culture. In 2012 Bruce's great-grandson, political activist Shane Bruce, blogged about "The Legend of Harve Bruce" on a right-wing website called Bludgeon and Skewer, an online blogspot '[h]ome to gun totin'; tin hat wearin'; Heinlein readin' rogue Libertarians considering HL Mencken's advice.” Proudly noting that the Winchester rifle "Great Grand Daddy Harve Bruce" used to kill the two federal marshals in 1897 now "sits in my gunsafe in the position of honor," Shane Bruce boasted that "[a]fter quite a bit of noodle time on the internets[sic] I have come to the conclusion that I have a long way to go to measure up to Great Grand dad." "He was a hell of a guy."94

\footnotetext{
92 "Captain Benjamin Franklin Taylor," in Ancestors of Jody Lawrence Drewry: Notes, online at http://www.angelfire.com/ut2/jldrewry/Jody/pafn07.htm, accessed July 1, 2013.

${ }_{93}$ Piney Page, "For Harve: Three Shots, Three Deer," Daily Courier-Democrat, October 17, 1982. This article was also transcribed and posted at Oak Springs Mountain Ranch.com, "The Legend of Harve Bruce"

(http://oakspringsmountainranch.com/Legend_of_Harve_Bruce.html), a website run by Bruce's great-great nephew, who is the current owner of what was once Harve Bruce's farm.

${ }^{94}$ Shane Bruce, "The Legend of Harve Bruce (My Great Grandpa)," Online Blog, Bludgeon and Skewer, posted May 10, 2012, (http://bludgeonandskewer.blogspot.com/2012_05_01_archive.html), accessed October 7, 2012. Shane Bruce also posted the 1982 Daily Courier-Democrat article on his blog. Robert A. Heinlein (1907-1988) was an
} 
The myths, stereotypes, and polemical spin that have shrouded this "moonshine war" and others, however, ignore a much more complex and largely forgotten history of radical rural populism and intra-regional conflict between the haves and the have-nots. For Bruce and his fellow moonshiner-farmers in the Ozarks, the elite favoritism and patronage-based operations of the federal Internal Revenue Service and the U.S. Marshals Service undoubtedly epitomized the unjust relationship between the privileged well-to-do and the status-quo designs of government power. As they toiled and sweated to eke out a living on their small hill farms and thought of new ways to prosper amid a national political-economy that proved to be increasingly rigged against them, the region's already-privileged elites controlled, administered, and benefitted from the power of these government agencies whose sole purpose was to suppress and criminalize their economic activities in the name of progress, productivity, and respectability. Indeed, this was hardly a story of "furrin" government bureaucrats invading the isolated domains of backwoods mountaineers. Practical rural desperation combined with competing local interests and visions amid uneven capitalist development in the region to concoct a very American recipe for radical populist defiance and explosive conflict.

Unfortunately for the poor and middling family farmers of the Ozarks, they would still be awaiting the fulfillment of their populist vision twenty years later. Rural populism in America influenced the launching of "a vigorous reform movement" during the early 1900s, and, in historian and political scientist Elizabeth Sanders's estimation, primarily “shaped the contours of

American science fiction writer from Butler, Missouri, whose stories emphasized themes of individualism, selfreliance, and nonconformity. H.L. Mencken (1880-1956) was an influential journalist, editor, and social critic from Baltimore who radically championed individual freedom against oppressive governments. Ironically, some of his best-known publications harpooned rural populists, especially in the South, and referred to Arkansas as the "apex of moronia," prompting the state legislature to pass a resolution in 1931 to pray for the atheist Mencken's soul. On Mencken and the South, see Fred C. Hobson Jr., Serpent in Eden: H.L. Mencken in the South (Chapel Hill: University of North Carolina Press, 1974). 
Progressive Era state expansion." New government functions included "the redefinition of trade policy; the creation of an income tax; a new, publicly controlled banking and currency system; antitrust policy; the regulation of agricultural marketing networks; a nationally financed road system; federal control of railroads, ocean shipping, and early telecommunications; and agricultural and vocational education." Its achievements, however, proved to be "more attuned with the aspirations of the [industrial and agribusiness-oriented] middle class" than those of small farm families. "Progressives worked energetically for agricultural education, farm-tomarket roads, tariff reduction, and some other reforms which would benefit agriculture in general," writes Arkansas political historian Joe T. Seagraves, "but not even Jeff Davis tried to alter the credit system or the landholding pattern" and other structural inequalities that buttressed the rising agribusiness industry and gradually eroded the viability of small family farms. "Conservative businessmen, lawyers, and large landowners still dominated the local power structure, despite the tremendous ferment and real gains won by the agrarian upheaval and the progressive movement. At the local level, in the ordinary operation of government, the great majority of Arkansas people found the political institutions scarcely more representative or responsive in 1918 than in $1874 .{ }^{, 95}$

Thus, dissent and defiance persisted in the Ozarks backcountry as small farm families continued to struggle against the odds and searched for ways to sustain their rural livelihoods, propelling new conflicts and, at times, radical resistance against government authority. Though largely forgotten in the folklore-dominated "history" of the region, some of the biggest stands against the "damn-guvment" in the Ozarks were taken by backwoods radicals when local elites

\footnotetext{
${ }^{95}$ Seagraves, “Arkansas Politics, 1874-1918,” 408, 411; Elizabeth Sanders, Roots of Reform: Farmers, Workers, and the American State, 1877-1917 (Chicago: University of Chicago Press, 1999), 7-8.
} 
utilized the government's "patriotic" power in 1917 and 1918 to demand that they and their sons put their lives on hold — and literally on the line — to go fight what they believed to be an unjust war schemed up by greedy capitalists and special interests. 


\section{Chapter Four \\ Won't Serve Greedy, Un-Godly Interests}

Sam Faubus - the father of Arkansas's notorious future governor, Orval Faubus-was born in 1887 and raised on a small backcountry farm in Madison County. A descendant of Scots-Irish immigrants who settled in the Appalachian Mountains during the 1750s and who fought in the French and Indian and Revolutionary wars, Faubus worked as a small family farmer and timber laborer in the rural Ozarks during the early twentieth century. Faubus, a product of the backcountry's more radical populist ethic, frequently expressed his vision of a just government that would ensure "economic and political equality" and reign in the unfairness of America's capitalist development. "I'd rather be an honest peasant/ Taking my living from the soil/ Than to be a rich parasite/ Living by others toil," he once penned for the concluding stanza of a poem. An agrarian Socialist and member of the ultra-conservative Combs Church of Christ—where he first encountered Socialist political ideas—authorities arrested and jailed Faubus in September 1918, during the First World War, for "distributing seditious literature and uttering numerous disloyal remarks concerning the conduct of the war." ${ }^{1}$ For Faubus and many other defiant backcountry farmers and laborers, the U.S. war effort represented nothing more or less than greedy and selfish corporate interests manipulating to their economic advantage the uneven status-quo system of government power at the expense of honest, hard-working common folks like themselves.

\footnotetext{
${ }^{1}$ Tom Wagy, "Little Sam Faubus: Hillbilly Socialist,” Arkansas Historical Quarterly 53 (Autumn, 1994): 263-276.
} 
For good reason, many popular and scholarly accounts tend to emphasize a patriotic "tradition of soldiering" among Ozarkers, Appalachian mountaineers, and other rural and smalltown Southerners. This traditional "fighting spirit" is generally assumed to be rooted in the same folk culture that is defined by uniquely rugged individualism, self-reliance, and tenacious defiance against government authority. ${ }^{2}$ Ironically, though, some of the most vociferous challenges to government intervention in the Ozarks during the early twentieth century involved rural folks resisting the U.S. Selective Service's compulsory military conscription in 1917 and 1918. While American soldiers were off fighting the Great War on the battlefields of Europe, federal and local officials throughout the Ozarks and other parts of rural America were engaged in battles of their own against backcountry folks who refused to have any part of what they saw as the government's "unjust" war.

Unlike the romantic tales of moonshiners resisting government encroachments upon liberty that long survived in the twentieth and twenty-first-century popular imagination, however, these stories of rural defiance during World War I have been ignored in the selective memory and lore about Ozarks culture. As Sam Faubus's son Orval later curiously recalled about his father's arrest, "You know, I never heard it mentioned in all my growing up in that community." 3 The memory of this incident and others like it in the region failed to serve the

\footnotetext{
${ }^{2}$ Popular historian and former U.S. Senator Jim Webb of Virginia perhaps best exemplifies these cultural images and assumptions in his book on America's Scots-Irish traditions. He reminds us that Southerners received 38 of the 118 Medals of Honor awarded for World War I service, "a rate well exceeding their proportion of the overall population." Throughout America's military history, rural folks such as those from the Ozarks and Appalachia have tended to serve on the front lines in substantially higher numbers relative to these regions' populations when compared to the rest of the country, and Webb attributes this unique "tradition of soldiering" to a well-preserved Scots-Irish culture in these "mountain and backland communities." "The warrior ethic," he writes, "has always been the culture's strong suit," though he never mentions that resistance to the draft during the First World War was stronger in the rural South than in any other region. James Webb, Born Fighting: How the Scot-Irish Shaped America (New York: Broadway Books, 2004), 253-256.

${ }^{3}$ Quoted in Wagy, "Little Sam Faubus," 276.
} 
interests of subsequent generations who helped paint and mold the dominant images of the Ozarks. These forgotten stories of draft resistance during World War I, nonetheless, reveal much about the historical dynamics of rural folks' defiance against government power in the region.

According to historian Jeanette Keith's study of the rural South during World War I, U.S. preparation and mobilization for war provided optimistic leaders at federal, state, and local levels the opportunity to implement new designs for a "modern managerial state." Alan Lawson reminds us, a good number of future New Dealers, including Franklin Roosevelt himself, cut their teeth in government administration during this First World War and borrowed heavily from these ideas and experiences as they worked toward government-managed relief, recovery, and reform during the Great Depression of the 1930s. ${ }^{5}$ But the efforts of the Woodrow Wilson administration and cooperating state and local governments to forge national unity and popular commitment to the U.S.'s war effort in Europe in 1917 and 1918 encountered much stiffer resistance than they had anticipated from some Americans, especially in rural regions such as the Ozarks.

While it is impossible to quantify the exact levels of opposition to and support for the war effort in the rural South, Keith's recent work shows that resistance against the war, especially against the government's compulsory military conscription, was much more widespread than historians have previously assumed, and this adds complexity to long-held assumptions about white Southerners as “the nation's most militaristic people... always ready to fight their nation's

\footnotetext{
${ }^{4}$ Keith, Rich Man's War, Poor Man's Fight, 4. On the First World War as a high-water mark for early twentieth century progressives in Arkansas, see Gerald Senn, “"Molders of Thought, Directors of Action': The Arkansas Council of Defense, 1917-1918," Arkansas Historical Quarterly 36 (Fall 1977): 280-290.

${ }^{5}$ See Alan Lawson, A Commonwealth of Hope: The New Deal Response to Crisis (Baltimore: Johns Hopkins University Press, 2006).
} 
wars." The story of resistance against the government's military draft in the Ozarks reveals a much more nuanced and complicated tale than the simplistic notion that a tradition-bound, isolated frontier culture produced an exceptional and homogenous population that was naturally "Born Fighting." Nor did resistance against this government intrusion simply stem from some unique parochial attitudes about governmental authority. Many of those rural Ozarkers who mounted the most determined forms of resistance to the government's war effort and draft, in fact, were ex-Populists and agrarian Socialists who otherwise demanded a strong government that would "fundamentally restructure the institutions of capitalist society" and help create "a more decent, fair, and just alternative to a world they knew to be fatally flawed."

Rural dissent against the war and the draft emerged because the government's military conscription meant real hardships for small farm families in the Ozarks who were already struggling to sustain their way of life. For many Ozarkers, it simply did not seem fair to have their young men sacrifice valuable time, labor, and possibly their lives fighting someone else's war in far-off Europe when their own country had not been attacked, especially since it seemed to be a "rich man's war" but a "poor man's fight." As they encountered the practical difficulties that compulsory military conscription added to their families' burdens, many rural Ozarkers understood this experience through the populist ethos that had been engrained in the region during the preceding years. This populism, furthermore, had absorbed dissenting religious convictions that convinced a number of rural Ozarkers that the government's war effort was an

\footnotetext{
${ }^{6}$ George Brown Tindall's classic survey of the South from 1913 through 1945, for instance, implies that resistance against the First World War came mostly from a rather small minority of discontented agrarians in the early part of the war effort but was rather quickly extinguished as "patriotic ventures overwhelmed the antimilitarism" after the U.S. declared war and began mobilization. George Brown Tindall, The Emergence of the New South, 1913-1945 (Baton Rouge: Louisiana State University Press, 1967), 48; Keith, Rich Man's War, Poor Man's Fight, quotation on 6; Webb, Born Fighting; Jim Bissett, Agrarian Socialism in America: Marx, Jefferson, and Jesus in the Oklahoma Countryside, 1904-1920 (Norman: University of Oklahoma Press, 1999), quotations on 4 and 8.
} 
unrighteous cause designed to enrich selfish, greedy, and powerful interests at the expense of honest, hard-working, God-fearing common folks like themselves.

Opinions about the unjust nature of the war effort, particularly the draft, also arose from and were compounded by the policies and decisions of the Selective Service's locally-run draft boards. Unlike the Confederate and Union drafts during the Civil War, one could not technically buy his way out of conscription or claim exemption based on certain indicators of wealth (i.e. the twenty-slave rule). Yet, in reality, as Jeanette Keith reminds us, class (and racial) prejudices characterized the implementation of the draft anyway, and this fact was quickly noticed by poor and middling farmers and laborers across the rural South. It would be a stretch to characterize the U.S. government's implementation of its Selective Service System as a fully top-down, statist act of "high modernism." Instead of sending officials from Washington or U.S. military bases into local communities to administer the conscription process on the ground, after all, the Selective Service followed a rather decentralized approach that organized and appointed local draft boards, typically comprising local justices of the peace, county government administrators, and other locally elected officials. Federal officials in Washington, moreover, "encouraged draft boards to make decisions about exemption based on local knowledge." Yet, despite what might have seemed like a more "democratic" approach, this system, ironically, "maximized the impact of the draft on poor families of all races" by opening the process to the prejudices and interests of local elites and their grip on the unequal distribution of power. Much like the battles over 
alcohol production in the rural Ozarks, conflicts over the draft were largely intra-regional affairs. $^{7}$

With significant leeway for local decision-making, local elites were prone to utilize their influential connections and pull to secure exemptions for their own sons and relatives, political friends and business associates, and employees whose labor they depended upon, while the boards denied the exemption requests of many small family farmers. When questioned about such decisions, of course, draft board officials usually insisted that their actions were in the best interests of the nation and community, often citing the necessities of keeping the local economy running at full steam and administering vital functions of the war effort on the home front. Meanwhile, small backcountry farmers - at least those without the proper connections - typically did not fare so well in applying for exemptions, and many did not buy the explanations draft boards gave when questioned about the fairness of their decisions. While the Selective Service typically exempted husbands and fathers deemed necessary to provide for dependent women and young children in their households, these exemption policies were designed and implemented primarily from the perspective of middle-class income standards. They did not, for instance, take into account the fact that drafting young males from rural communities often threw a wrench into the operations of small family farms, because they depended upon this key source of labor for their families' and communities' sustainability. The real burdens of the draft, then, were all the more irritating to many small farm families in light of the practices of local draft

\footnotetext{
${ }^{7}$ Keith, Rich Man's War, Poor Man's Fight, 9-10, 60. Quotations on 10,
} 
boards, which tended to represent the interests of local elites at the expense of rural common folks such as themselves. ${ }^{8}$

As the drums of war began to rumble across America and the government's policy of "preparedness" got underway after 1914, the Woodrow Wilson administration faced some of its stiffest opposition from rural Americans and certain members of its own Democratic Party in the South, especially from those leaders who had begun their political careers amid the agrarianpopulist insurgency in the 1890 s, or just after the turn of the century. Their positions against the war effort indicate much about the sentiments of their grassroots constituents, especially since many of these political leaders had witnessed the Populist revolt firsthand and knew the consequences politicians could face if they ignored and angered rural voters. Notable southern political leaders such as Tom Watson of Georgia, John H. Bankhead of Alabama, Claude Kitchen of North Carolina, James K. Vardaman of Mississippi, and Sidney Catts of Florida railed against the "unreasonable and unnecessary preparedness" for war, brought on, they exhorted in typical populist language, for the sake of big moneyed "manufacturers of munitions and war supplies that are being exported to Europe at immense profits." ${ }^{\text {ㅇ }}$ By 1917 Arkansas had its own "progressive" Wilsonite governor in Charles H. Brough, a former University of Arkansas political science professor, who ensured that the president and the war effort had his state's full cooperation. But some of the state's most important populist-leaning political leaders voiced loud opposition to the war.

${ }^{8}$ Ibid., 9-10, 60, 116.

${ }^{9}$ Tindall, The Emergence of the New South, 40-44. Quotation is statement made by Bankhead quoted by Tindall on 41. For a recent in-depth treatment of Tom Watson's opposition to the war, see Zachary Smith, "Tom Watson and Resistance to Federal War Policies in Georgia during World War I," Journal of Southern History 78 (May 2012): 293-326. 
The torch-bearer of the agrarian-populist wing of the Democratic Party in Arkansas, Jeff Davis, had suffered a massive stroke and died in January 1913, but his political ally and fellow U.S. Senator, James P. Clarke, aggravated the Wilson administration by helping stir up opposition against a number of the president's early war preparation plans until he, too, died in October 1916. Clarke, it should be mentioned, had been Arkansas's governor during the middle of the agrarian-populist revolt in the 1890s and, having read the stormy winds of popular political opinion, aligned himself with Jeff Davis and donned a populist image in his subsequent race for the Senate and his political career after the turn of the century. His successor in the Senate, William F. Kirby, picked up right where Clarke had left off, opposing and filibustering Wilson's policies of "armed neutrality" and war preparation. Though he ultimately relented to vote in favor of the U.S declaration of war in April 1917, Kirby wanted to note for the record his grave reluctance by explaining that "if there was the slightest chance on God's earth that my vote against it would defeat it, I would stand here and vote a thousand years if it might be that we do not go to war." Senator Kirby undoubtedly made sure these comments found their way to the eyes and ears of his populist rural constituents. ${ }^{10}$

Opposition to foreign military intervention was nothing new in the Arkansas Ozarks. In April 1898, as American leaders debated about and geared up for U.S. military action against

\footnotetext{
${ }^{10}$ The political career of Clarke is briefly discussed in Richard L. Niswonger, "Eighteenth Governor: James Paul Clarke, 1895-1897," in The Governors of Arkansas: Essays in Political Biography, Second Edition, edited by Timothy B. Donovan, et al., (Fayetteville: University of Arkansas Press, 1995), 105-106. Jeff Davis's untimely death is discussed in the same volume in Raymond O. Arsenault, "Jeff Davis, 1901-1907," 130. On the anti-war positions of Senators Clarke and Kirby, see Dougan, Arkansas Odyssey, 376. For a good look at Kirby and his political career see Richard L. Niswonger, "William F. Kirby, Arkansas's Maverick Senator," Arkansas Historical Quarterly 37 (Fall 1978): 252-263. Kirby, however, also supported the use of dragnets to apprehend draft evaders in a Senate debate over rampant draft dodging in New York City and the constitutionality of mass arrests. Judith Sealander, "Draft Evasion in the South during the First World War," (unpublished master's thesis, University of Arkansas, 1973), 37-38 n6.
} 
Spain in Cuba, Searcy County's anti-war newspaper, the Mountain Wave, defended against those interventionists who questioned the patriotism of war opponents:

The man who hastens to answer the call of his country and fights her righteous battles is a patriot— - but he who refuses to bear arms for his country in an unjust cause is a greater one. The man who respects and loves his flag is a patriot—but he who tears it from its staff when unfurled for an unholy cause exhibits a patriotism of purity...This so-called patriotism [espoused by interventionists]pure shoddy, warp and woof - that causes men to be silent and pass by unnoticed wrongs against their country because the perpetrators are high in office, have a political pull or are big guns in the community—is the veriest [sic] rot, the essence of anarchy and the seeds of ruin. ${ }^{11}$

In November 1899, the Wave proudly printed the remarks of the populist, anti-imperialist William Jennings Bryan, who had recently called down a pro-war interventionist who contended that U.S. control of the Philippines would best serve the interests of the nation's economy. Bryan's "eyes flashed fire," the paper reported, "as he thundered: 'I dare you to measure the lives of American boys and the heart aches of American mothers by the paltry dollars and cents of commerce; I dare you do it!" "You are not preaching the gospel of the Prince of Peace," Bryan continued. "You're preaching the infernal gospel of conquest and murder and death." The Wave applauded Bryan's passionate defiance and gladly noted that “the orator's last words were drowned in a tempest of cheers." ${ }^{12}$ Ironically, as we shall see, Searcy County's booster-oriented

\footnotetext{
11 "Patriotism," Mountain Wave, April 8, 1898.

12 "Squelching an Imperialist," ibid., November 4, 1899.
} 
paper changed its tune about war opponents rather dramatically by 1917. Upon America's entry into the First World War and in the face of continued rural resistance, the Wave would come to demand absolute conformity to the town of Marshall's and local war supporters' "over the top" patriotism for the U.S. war effort.

Despite a general consensus of opposition to initial calls for war, many Ozarkers-most likely a solid majority—fell into line when their country declared war in April 1917. Like William Jennings Bryan, who had even resigned his post as U.S. Secretary of State in protest against the Wilson administration's drift toward more aggressive militarization, many rural Americans, "now that the United States was officially, unalterably at war...could not imagine opposing it," especially in this total war environment. "Few of his followers," writes historian Michael Kazin, "seemed to challenge that reasoning." The average rural American, after all, as Bryan's evolving position might indicate, "had never been that kind of rebel," despite real reservations. Indeed, Bryan co-opted patriotism into his broader agenda for populist reform, such as "mingl[ing] anodyne pleas for conserving food with more spirited attacks on businessmen who sought to profit from the economic boom." As Keith explains of rural folks in Tennessee's mountains, "regardless of whether people in the Upper Cumberland would have chosen to go to war with Germany in 1917, once the war began and American troops were committed, many felt obligated to help 'the boys.",13 Many Ozarkers undoubtedly felt the same way. Opposition, however, remained significantly strong in the region.

\footnotetext{
${ }^{13}$ Michael Kazin, A Godly Hero: The Life of William Jennings Bryan (New York: Anchor Books, 2006), 254-255; Jeanette Keith, Country People in the New South: Tennessee's Upper Cumberland (Chapel Hill: University of North Carolina Press, 1995), 161.
} 
It is impossible to measure just how many rural Ozarkers at the grassroots supported or opposed the war effort during World War I, especially since both government and private resources were heavily employed to silence many critics. There is, however, ample evidence to suggest that grassroots opposition was strong in rural areas of the Arkansas hills, just as it was throughout other parts of the South. According to a U.S. War Department report issued in 1920, 8,732 Arkansawyers, or over 15.5 percent of the state's total military inductees, failed to report for duty or deserted during the war, a figure that stood well above the national average, and this did not include those who had refused to register for the draft in the first place. ${ }^{14}$

Of course, draft evasion, desertion, or any other behavior that might be deemed unpatriotic were actions that everyone- even those in the most remote backwoods hollerunderstood could result in dire consequences for themselves and perhaps even their families. A number of Ozarkers, then, undoubtedly complied grudgingly, and many of them did so only after applying unsuccessfully to local draft boards for exemption. By the summer of 1917, federal, state, and county governments had established defense councils to mobilize the population and economy for the war effort, rally patriotic support from citizens, and suppress any and all dissent. Numerous and powerful sources of censure bombarded and muffled voices of opposition. Federal, state, and local governments created massive surveillance and propaganda agencies. Local businessmen and elites organized and led "home guards" and "citizens groups" that dotted cities and towns throughout the country and worked diligently to sniff out "slackers." Local, state, and national newspaper editors sought to instill a sense of unified patriotic fervor in their

\footnotetext{
${ }^{14}$ These statistics from Final Report of the Provost Marshall to the Secretary of War on the Operation of the Selective Service to July 15, 1919 (Washington: Government Printing Office, 1920), are transcribed in James F. Willis, "The Cleburne County Draft War," Arkansas Historical Quarterly 26 (Spring 1967), in footnote 3 on page 25. The national average of deserters and delinquents was 12.24 percent of total inductees.
} 
readers and mobilize an exceptional commitment to national duty. And overly enthusiastic neighbors who might have suspected that a certain person, family, or group was not going "over the top" in supporting the war effort—or have just seen a convenient opportunity to settle an old grudge - commenced neighborhood campaigns of humiliation and intimidation in the name of American patriotism. Consequently, many opponents in the Ozarks, as elsewhere, must have quietly acquiesced to the demands of the government's war effort in order to avoid the ridicule and punishment that might visit them and their families, however truly resentful they may have actually been. As Keith puts it, "People could speak as much as they pleased in favor of the war, but dissenters faced federal prosecution.” Thus, only the stories of those opponents who opted to take more overtly confrontational and risky stances of resistance emerge from the historical record. $^{15}$

Middle-class urbanites and townsfolk administering the federal government's war effort in the state and region typically attributed the resistance they faced to simple mountain isolation and a parochial culture of stubbornness and ignorance. Nonetheless, opposition against the draft arose in the region's more "progressive" rural areas as well. In Washington County, for instance, on the fertile, gently-rolling Springfield Plain in the northwest corner of the Arkansas Ozarksthe home of the University of Arkansas and one of the most prosperous and "forward-looking" counties in the state - officials, lawmen, and patriotic citizens had to work diligently to suppress dissent, especially in smaller farm communities. In May of 1918, the editor of the county's leading newspaper, the Fayetteville Democrat, printed a short fictional story titled "The Pacifist

\footnotetext{
${ }^{15}$ On the magnitude of government and private surveillance and the suppression of dissent in the rural South, see Keith, Rich Man's War, Poor Man's Fight, 135-161; and Keith, Country People in the New South, 143-169, quotation on 161. Keith also discusses the impossibility of measuring levels of support for and opposition to the war effort due to the overwhelming surveillance and propaganda that worked to silence dissent, except in more extreme cases of resistance.
} 
and His Girl," hoping to help quell dissent against the war in the area. The tale was about a young man who "lost both his girl and his freedom" because his "intelligence" and "personal convictions" led him to oppose the war. His disgusted girlfriend resented his cowardice and not only ended their relationship but also turned him over to federal authorities. "That's one case out of many," the editor concluded. "There's a good deal more of genuine, practical patriotism bottled up in the girl power of this country than most men imagine. And many a smart youth is learning it to his cost.",16

Dissent against the war in Washington County continued, nevertheless. That same month, officials reported "that a nest of American Bolsheviki has been breeding in the hills along the line of Washington and Crawford counties," a dangerous group, they believed, that sought to undermine the war effort. Preston Martin, a seventy-five-year-old farmer and country merchant from the Strickler community, and his thirty-two-year-old son were subsequently arrested and hauled before a federal grand jury on charges of sedition. ${ }^{17}$ A few weeks later, the county's Food Administration reported that some anonymous war opponents, supposedly out of Elkins and Greenland, were circulating deceitful, "pro-German" pamphlets among area farmers in their attempts to undermine the government's wheat drive for the war effort. ${ }^{18}$

Lawmen and citizen patriots stepped up their hunts for war opponents and draft evaders in the county over the next several months. In August, Dr. W.T. Blackburn, a civilian posseman appointed by the local Council of National Defense in the small town of Lincoln, arrested a "Holly [sic] Roller" preacher, F.D. Davidson, for delivering a speech in his community that

\footnotetext{
16 “The Pacifist and His Girl," ibid., May 30, 1918.

17 "Strickler Farmer is Charged with Sedition," Fayetteville Democrat, May 30, 1918.

18 "Pro-Germans Circulate False Reports on Wheat," ibid., June 27, 1918.
} 
passionately condemned the government's war, claiming that President Wilson was the "beast" referred to in biblical scriptures prophesying the End Times and railing that the female Red Cross workers were "no better than harlots." ${ }^{, 19}$ And the following month, local deputies apprehended twenty-three-year-old deserter Albert Denny as he left his brother's farmhouse near Hazel Valley, shooting both of his legs to prevent his escape. ${ }^{20}$ Draft resistance, then, was more widespread throughout the rural Ozarks than many liked to imagine.

The first major episode of violent draft resistance in Arkansas occurred in Polk County in the Ouachita Mountains in the southwestern part of the state near the Oklahoma line. Local lawmen there began hunting rural draft resisters in late 1917, resulting in a raid and violent shootout between county lawmen and draft evaders in December. Authorities suspected that the draft resisters in Polk County were connected to the recent Green Corn Rebellion, the nationallypublicized stand against the draft that had been waged by disgruntled tenant farmers and members of the Working Class Union (WCU) across the state line in Oklahoma in August. Most of the draft resisters in Polk County, in fact, were small farmers and rural laborers at least loosely affiliated with the Socialist Party, the WCU, or the Industrial Workers of the World. They were also suspected of having illegal bootlegging connections with their fellow rural radicals in neighboring Oklahoma. Conflict between local authorities and the draft evaders persisted during the following months, including the killing of a local Council of Defense member during an altercation with some anti-war farmers when he attempted to collect crop statistics and pledges for the federal government's food census. Authorities also suspected that three recent robberies were connected to the draft resisters. The conflict in Polk County came to a head on May 25,

\footnotetext{
19 “Holy Roller Preacher Under Arrest Here," ibid., August 22, 1918.

20 “Alleged Deserter is Captured Near Hazel Valley,” ibid., September 19, 1918.
} 
1918, when the sheriff and a posse of thirty-six men raided the draft resisters' hideout and exchanged volleys of gunfire. The "Battle of Hatten's Gap," as the incident became known, resulted in two deaths, three wounded, and numerous arrests. Ultimately, juries sentenced one draft evader to the electric chair, one to life in prison, one to a ten-year prison term, and several others to lesser penalties. In late August, about a week before the scheduled execution of draft evader Ben Caughron — an agrarian Socialist who said he, like "many mountain men," believed the war was "a rich man's war"-Governor Brough announced that he would not "interfere" in the matter and, according to one regional newspaper, vowed that "he will so long as he is governor use his official power to enforce rigidly the majesty of the law in preventing resistance to federal and state authorities...He believes that an example should be made in this case that will serve notice to all draft resisters., 21

While some observers were confident that the violent showdown in Polk County and the subsequent "example" made by authorities would settle the issue of draft resistance throughout the state, such hopes proved to be wishful thinking. Reports of draft resistance in Arkansas continued, a significant number of them coming from the Ozarks. In early June of 1918, local lawmen and a citizens' posse organized in the town of Marshall, the seat of local government for Searcy County, deep in the heart of the Ozarks, to root out draft resistance in their area. Townsfolk in Marshall and neighboring towns had been brimming with New South optimism ever since certain parts of their area had undergone a lead and zinc mining boom in the 1890s,

\footnotetext{
${ }^{21}$ J. Brett Adams, "The Polk County Rebellion," unpublished paper presented at the Third Annual Ozarks Studies Symposium, West Plains, Missouri, September 2009, in possession of author; Sealander, "Draft Evasion in the South," 41; "Brough Not to Commute Draft Resister's Sentence," Fayetteville Democrat, August 22, 1918. On the Green Corn Rebellion in Oklahoma, see James R. Green, Grass-Roots Socialism: Radical Movements in the Southwest, 1895-1943 (Baton Rouge: Louisiana State University Press, 1978), 359-366; and Bissett, Agrarian Socialism in America, 149-155.
} 
and then the St. Louis and North Arkansas Railroad extended into Searcy County in 1903 to stoke a bonanza in the timber industry. Supporting the U.S. war effort was their chance to demonstrate the civic virtue, patriotism, and progress of their towns. Marshall's leaders organized numerous "Patriotic Meetings" throughout the fall of 1917 and 1918, inviting prominent speakers and musicians from around the state and country to drum up local support for the war effort, as well as organizing groups and leadership committees to rally the county's citizens behind the national cause. Circuit Court Judge John Worthington even believed it necessary to turn "the first day of court over to these patriotic meetings after the juries have been impaneled" so that organizers for the war effort would have full, unhindered access to the courthouse and the town folks' undivided attention. By April of 1918, war supporters in Searcy County were proud to boast that Marshall had gone "over the top" in raising $\$ 16,050$ in liberty bond subscriptions, a figure that exceeded the town's quota by $\$ 4,050$. The local high school also held a fundraising rally and contributed an additional $\$ 1,250$ to the cause. "Tomorrow your neighbor or your neighbor's boy may give his life for our country," read an ad in the Mountain Wave for a series of "Patriotic Rall[ies]" to be held throughout the county in March of 1918. "Are you a Patriot or a slacker? If you are a Patriot, rally around 'Old Glory.",22 Visions of prosperity, progress, and development combined with American patriotism to have the Wave singing a new song; its attitude about dissent had changed remarkably from the positions it had taken during the Spanish-American War effort.

Unfortunately for the "Patriots" in Searcy County, there were more "slackers" in their midst than they cared to admit — or cared to put up with. The anti-war sentiments in their county,

\footnotetext{
${ }^{22}$ Mountain Wave, November 9, 1917; February 8, 1918; March 8, 1918; April 12, 1918; July 26, 1918.
} 
in fact, had even attracted the attention of the Little Rock office of the federal government's Bureau of Investigation, the U.S. Justice Department's surveillance agency charged with monitoring and investigating individuals and groups suspected of posing a dangerous threat to the nation. In the summer of 1917, the Bureau had obtained a copy of a Searcy County newspaper, The Leslie News, which had published articles and letters that were critical of U.S. involvement in the World War. One article, titled "The United States Has Placed an Order for 200,000 Coffins!," received top billing on the front page of the paper's June 22 edition and warned readers that "[t]hose coffins are to be occupied—by somebody's boys!" The paper also printed a letter that urgently called for "the total defeat of the Allied Money power" and proposed that the U.S. government's massive war spending be entirely redirected to "conserving human life instead of destroying it" by offering $\$ 3,000$ apiece to any German soldier who would voluntarily surrender, a strategy that would surely bring a rapid end to the war. These "prisoners" of war, it continued, now "with hands washed pure from blood," could then be employed by the government and supervised by "American boys" no longer needed on destructive battle fields to begin amassing a "Grand Army of the World" that would dig canals, build roads, reclaim desert lands, work to eliminate hunger, and develop fair and secure employment for people around the world. "Who will combat this solution of the war, this solution that would heal every wound, banish all hatred, that would establish charity for all and malice toward none, as in the great American melting pot the races met on common ground?," the letter asked. “The Money Power, the Money Power, THAT DOES NOT WANT THE WAR TO END." 23

${ }^{23}$ Leslie News, June 22, 1917. 
After an investigation by the Bureau, however, agent C.M. Walser reported that, while he would be sure to keep an eye on the newspaper's future activities, the Leslie paper no longer appeared threatening. Walser's investigation discovered that the owner of the paper, E.B. Bedford, was a native-born American and a member of the Christadelphian Church, "whose teachings he claims are against war.” The agent also found that the paper's editor, J.L. Barnett, also a native-born American, was a member of the Socialist Party. Nonetheless, Walser reassured his superiors that he had been "informed by subscribers...that they have ceased publishing such articles," and he was confident that the "postmaster and other loyal citizens" would let the Bureau know "if any more should appear."24

But if such vocal and publicized opposition against the war effort had mostly fallen silent in Searcy County by 1918, compulsory military conscription ensured that dissent would not go away. In early June, Sheriff J.H. Barnett received a tip that "Pet" Goodman was harboring draft evaders at his farm and home near Oxley in the eastern part of the county. According to lawmen, word had circulated that the Goodmans vowed not be taken without a fight. One of the Goodman boys, it was reported, had even committed suicide "rather than enter military service," after he had been drafted by the local Selective Service board and ordered to report to Marshall for a medical examination several months before. The sheriff and his posse left Marshall late in the night and surrounded Goodman's farmhouse, where they waited patiently until daylight the following morning to conduct their raid. When the time came, Sheriff Barnett shouted to Goodman and his guests to surrender themselves. According to the lawmen, Levi Goodman, "Pet's" oldest son and a deserter, reached for his gun, and one of the officers opened fire, killing

${ }^{24}$ C.M. Walser, "In re—Leslie News, Leslie, Arkansas. Disloyal Newspaper,” Report no. 71793, October 24, 1917, U.S. Bureau of Investigation Case File Archives, www.fold3.com/image/\#975423. (Accessed December 10, 2012). 
him instantly. "Pet" Goodman, his other son and draft resister Eli Goodman, and a neighbor and fellow deserter Wesley Passmore subsequently surrendered and were hauled to the county jail in Marshall. The next day officials took the Goodmans to Harrison in Boone County, where they were held for a federal hearing, and escorted Passmore back to military officials at Camp Pike in Little Rock. In August, Eli Goodman was ordered into military service at Camp Funston in Fort Riley, Kansas. ${ }^{25}$

Press reports revealed little about the motives of the Goodmans and Passmore, and there does not appear to have been a trial over the affair. The federal commissioner who heard the charges against the Goodmans may have felt that the death of two sons and then Eli's impressment into military service at Camp Funston were punishment enough. While neither the local newspapers nor the Arkansas Gazette addressed a motive, the Fayetteville Democrat suggested that the Goodmans' and their neighbors' "pernicious Socialis[m]" must explain their anti-war positions and stubborn defiance against the draft. ${ }^{26}$ Indeed, since agrarian Socialism had a particularly significant presence in Searcy County among small farmers and rural laborers during the early twentieth century, the Fayetteville newspaper, despite its unsympathetic hyperbole, may have been on the right track. The lives and experiences of the Goodmans and the Passmores, after all, were not unlike the thousands of other small farmers and rural workingclass folks in the western South who joined the ranks of the Socialist Party during the early twentieth century to champion what they believed would be a more just political economy that

\footnotetext{
25 “Alleged Resister of Draft is Shot," Arkansas Gazette, June 6, 1918; "Levi Goodman, Deserter, Killed," Mountain Wave, June 7, 1918; ibid., August 9, 1918.

${ }^{26}$ Quoted in Todd Deatherage, "World War I Draft Evasion and the Ozark Mountain Draft Wars," unpublished student paper (University of Arkansas, 1989), 9.
} 
would curtail the unfair exploitation of wealthy and powerful capitalists and rightfully return the fruits of productive labor to hardscrabble farmers and workers.

Hardscrabble farming, indeed, was all "Pet" Goodman had ever known. Goodman was born in 1867 to William E. and Martha Goodman in Searcy County. Several years before he was born, William and Martha began their lives together on a small farm in Lewis County, Tennessee. By 1860, however, William had given up farming to become a blacksmith. Sometime during the tumultuous decade of the 1860s, the Goodmans headed east to Big Flat Township in Searcy County, Arkansas, where William worked in a blacksmith shop and his four oldest sons, ranging in age from eleven to seventeen, worked as farm laborers. By 1880 , with young "Pet," now twelve years old, William quit blacksmithing and the family ventured across the county line to settle on a small rugged hill farm in Stone County. ${ }^{27}$

By the turn of the century, "Pet" Goodman had married a young woman from Kentucky and the couple had settled on a small farm of their own in Campbell Township in Searcy County, where they were raising three young boys. Ten years later, the Goodmans had added three more children to the family, and their three oldest sons, now sixteen, fourteen, and twelve, were old enough to provide their father with valuable labor on the family farm, especially in this era of increasingly commercial-oriented agriculture that proved more and more difficult for small farmers to compete. In 1911, the Goodmans owned one horse, three cattle, one mule, twenty-

\footnotetext{
${ }^{27}$ Manuscript Census Returns, Seventh Census of the United States, 1850, Population Schedules, District 10, Lewis County, TN; Eighth Census of the United States, 1860, Population Schedules, District 3; Ninth Census of the United States, 1870, Population Schedules, Big Flat Township, Searcy County, AR; Tenth Census of the United States, 1880, Population Schedules, Locust Grove Township, Stone County, AR.
} 
five hogs, one wagon, and $\$ 50$ worth of equipment and other personal assets, for a combined personal property assessment of $\$ 330 .^{28}$

"Pet's" sons were apparently still living in his household when the government initiated the military draft in 1917, and all three were called up by the local draft board in Marshall. This without a doubt placed a major strain upon the Goodman family, just at a time, in fact, when farmers in the Ozarks and elsewhere in rural America were beginning to see new hopes for a better economic future as international demand for American farm products during the war began driving agricultural prices upward. Like many other hill farmers who sought to take advantage of these new economic opportunities, it appears that the Goodmans had begun expanding production on their family farm during the war as well. By the end of the war, they had purchased an extra mule, a relatively expensive investment for a poor hill farmer, indicating that they were probably tilling more land and producing more crops than before. They also appear to have sold off several hogs and some other assets and reinvested in a few more cattle, a move made by a number of hill farmers during the war years to capitalize on unprecedented beef prices. ${ }^{29}$ The government's mandatory military conscription, then, which promised to strip away the family's most important labor source and strap them with seemingly unnecessary burdens, may have validated for the Goodmans and several of their rural neighbors the Socialists' and other agrarian-populists' claims that this was a "rich man's war, and a poor man's fight."

\footnotetext{
${ }^{28}$ Manuscript Census Returns, Twelfth Census of the United States, 1900, Population Schedules, Campbell Township, Searcy County, AR; Thirteenth Census of the United States, 1910, Population Schedules; Personal Assessment Records, 1911; 1919, Searcy County Courthouse, Marshall, AR.

${ }^{29}$ For a more thorough discussion of the war's impact on the farm economy in the Ozarks, particularly on cattle farming, see the following chapter.
} 
The Goodmans and their neighbors also lived in an area which had a strong historical precedent of suspicion toward and opposition to seemingly unjust wars conjured up by "elites" for their own selfish interests. Some of the Passmores, one of the largest extended families in the community that had deep roots in Searcy County's early settlement, in fact, had participated in the Arkansas Peace Society's dissent against secession and the Confederacy back in 1861. A secretive organization of loosely affiliated anti-Confederate groups, comprised mostly of small hill farmers, the Peace Society was eventually hunted down and quashed by the Confederacy and local militias; many of its members were subsequently impressed into Confederate military service. ${ }^{30}$ The Passmores, like the Goodmans and many other Ozarkers, were also struggling to sustain and reproduce their small-farming households during the late nineteenth and early twentieth centuries in the face of confusing economic and social changes that increasingly stacked the odds against them. Back in 1892, John Passmore, the father of deserter Wesley Passmore, owned no horses, no mules, eight cattle, fifteen hogs, one wagon, $\$ 5$ worth of gold or silver, and \$20 worth of equipment and other personal assets. By 1911, he owned two horses, one mule, fourteen cattle, thirteen hogs, one wagon, and $\$ 150$ in equipment and other assets. Vital to Passmore's small farming operation, especially by 1918, was the labor of twenty-threeyear old Wesley, two other sons who were either already eligible for the draft or would soon become eligible within a few months, and two younger sons just entering adolescence. The government's burdensome draft for a seemingly unnecessary war, then, must have appeared to

\footnotetext{
${ }^{30}$ Luther E. Warren, Yellar Rag Boys: The Arkansas Peace Society of 1861 and Other Events in Northern Arkansas, 1861 to 1865 (Marshall, AR: Sandra L. Weaver, 1993), 11. On the Arkansas Peace Society, see ibid., 1-19; James Johnston, “Arkansas' 1861 Peace Society," Arkansas Family Historian 29 (March 1991): 13-29; Ted R. Worley, "The Arkansas Peace Society of 1861: A Study in Mountain Unionism," Journal of Southern History 24 (November 1958): 445-456; and Ted R. Worley, "Documents Relating to the Arkansas Peace Society of 1861," Arkansas Historical Quarterly 17 (Spring 1958): 82-111.
} 
the Passmore family as an intrusive, unwanted obstacle inhibiting their quest to get ahead and stay ahead in rural America. ${ }^{31}$

While none of the brief newspaper reports mentioned their faith in explaining the Goodmans' and Passmore's actions, their religious convictions may have also played a significant role in their decision to resist the draft. According to local historians and family descendants, most of the rural residents in the Oxley area were members of small independent Baptist churches, many of whom considered themselves non-denominational Christians. While mainline denominations, especially in towns, often counted themselves among the most supportive of the U.S. war effort, many dissenting, albeit fundamentalist, Christians in the region and throughout the rural South, including members of the Churches of Christ, Holiness and Pentecostal churches, independent Baptists and Methodists, and non-denominational groups, considered the military conflict an unrighteous, "unjust war," at times even going so far as to condemn the U.S. government's actions as "murderous." 32 Furthermore, members of such "churches of the disinherited" in the Ozarks and other parts of the western South were frequently drawn to agrarian-populist and agrarian-Socialist politics, basing their political beliefs, in large part, on their interpretations of scripture and the message of love, peace, and justice exhibited by their savior Jesus Christ-what they considered the "The Real Gospel of Christ." Goodmans' and Passmores' particular religious beliefs about the war are unknown, but it is, perhaps, reasonable to speculate that dissenting religious faith may also have helped motivate their resistance against the draft.

\footnotetext{
${ }^{31}$ Personal Assessment Records, 1892; 1911; Manuscript Census Returns, Thirteenth Census of the United States, 1910, Population Schedules.

${ }^{32}$ Pat Halstead interview with author, August 30, 2012; Keith, Rich Man's War, Poor Man 's Fight, 76-83.

${ }^{33}$ Bissett, Agrarian Socialism in America, 85-104, quotation on 98.
} 
There is no question that religion figured prominently in the Adkisson family's and their rural Cleburne County neighbors' opposition to the government's war effort and military conscription. On July 6, 1918, Cleburne County Sherriff Jasper Duke organized a posse in the county seat of Heber Springs to hunt down stubborn draft resisters in his county, offering $\$ 50$ apiece to the four "patriotic" citizens who joined him. Their sights were set on the Adkisson family and their rural neighbors in the hills between the villages of Pearson and Rose Bud near the White County line. That family's patriarch, Tom Adkisson, had been a thorn in the side of the local draft board since at least the previous October when his son Bliss refused to report for military service, and many of his neighbors had also refused to comply. The Adkissons were premillennialist Russellite Christians (modern-day Jehovah's Witnesses) who believed that the war was the Satanic conspiracy long prophesied to usher in the biblical Apocalypse. While the Adkisson sons and several of their rural neighbors had registered for the draft, many of them had requested religious exemptions on the grounds that they were members of the International Bible Students Association and conscientious objectors to the war. Their requests were denied by the local draft board in Heber Springs. ${ }^{34}$

When Duke and his posse made their move at the Adkisson farm early on the morning of July 17, a brief gunfight ensued, leaving one of the sheriff's possemen fatally wounded. Sheriff Duke and his men retreated back to Heber Springs to gather reinforcements and returned with twenty-five men to the Adkisson farm that afternoon. Meanwhile, the Adkissons had rounded up a number of neighbors to help mount a defense, and they stood ready when the posse returned. Another shootout erupted — this one lasting for forty-five minutes—-but the draft resisters, despite

\footnotetext{
${ }^{34}$ See Hardy Adkisson, Charley Bliss Adkisson, and Leo Martin, World War I draft registration cards, Cleburne County, AR, available at Ancestry.com (accessed December 23, 2012).
} 
being outnumbered, were well-positioned around the farmhouse and surrounding structures, in the nearby woods, and even in treetops. Realizing the numerical odds were against them, however, the Adkissons and their comrades eventually escaped into the woods where they eluded authorities for over a week. The draft evaders and their accomplices were finally taken into custody only after a dramatic manhunt, conducted by county and state lawmen, area "home guards" and volunteer possemen, and even a unit of the $4^{\text {th }}$ Arkansas Infantry, National Guard, making the "Cleburne County Draft War" one of the most notorious instances of draft resistance in the South. ${ }^{35}$

For Russellite Christians throughout the United States, the World War at hand was a fulfillment of the prophesy of their recently deceased religious leader, Charles Taze Russell, who had predicted since the 1880s that the millennium would come after 1914. Russell had described how the nations of the world, long corrupted by sinful and self-serving religious and secular officials, would crumble into destruction and disorder, ushering in the biblical Second Coming of Christ and his thousand-year reign and Final Judgment. Only Christ's true followersthemselves and fellow Russellites—-would inherit God's reward, while the evil—non-believers and those so-called Christians who had diluted and tainted the purity of scripture-would suffer destruction and eternal damnation. By the outbreak of war, Russellites "underst[ood] that the spirit of selfishness and ambition, which is driving the nations insanely to war for commercial

\footnotetext{
${ }^{35}$ Willis, "The Cleburne County Draft War," 24-39; Keith, Rich Man's War, Poor Man's Fight, 189-90; Arkansas Gazette, July 8-21, 1918. The Cleburne County incident made national news in a New York Times article on July 8, 1918 , though it erroneously reported the number of fatalities and that Adkisson and his son were killed. "3 Killed in Battles with Draft Evaders: Band in Arkansas Wood Fight Officers with Rifles Until Their Leaders Fall," New York Times, July 8, 1918.
} 
supremacy, will increase more and more, and will involve everybody." ${ }^{36}$ Thus, the pure had to stand firm. When the Selective Service called up the Adkisson boys and other young Russellite men from their Cleburne County farm community in 1917, they viewed their experience as a fight between the righteous and unrighteous, between true followers of God and a sin-filled, selfand Satan-serving government standing on the side of evil in the Armageddon. The eagerly awaited Apocalypse was at hand, they believed, and their eternal life depended upon their undefiled commitment to God's will and their defense against impure and corrupted government officials' evil earthly designs. ${ }^{37}$

To gain a better understanding of this episode and the attitudes and experiences that led to such impassioned resistance, however, it is important to understand that the elder Adkissons and their neighbors did not inherit a tradition of Russellism in their community, for this was a fairly recent religious movement, especially in Cleburne County. Rather, social and economic conditions and their personal experiences in the Ozarks during the late nineteenth and early twentieth centuries likely made them ripe for conversion to this new religious faith, and the outbreak of the World War and the practical pains of the draft only gave Russell's prophesies that much more credibility. Their experiences were the typical struggles of rural Ozarkers, and they likely found comfort and security in this new radical Christian doctrine which ensured them that their earthly hardships and sorrows would soon be rewarded. Their faith, not surprisingly, promised the greatest of all populist justice. As historian Edward H. Abrahams explains, such

\footnotetext{
${ }^{36}$ Charles Taze Russell, The Finished Mystery, Studies in the Scriptures, Series VII (Brooklyn, NY: International Bible Students Association, 1918), quotation on 51.

${ }^{37}$ On Russell's movement and his and his followers' beliefs, see James A. Beckford, The Trumpet of Prophecy: A Sociological Study of Jehovah's Witnesses (New York: John Wiley \& Sons, 1975), 1-20; Andrew Holden, Jehovah's Witnesses: Portrait of a Contemporary Religious Movement (London: Routledge, 2002), 7-19; and Edward H. Abrahams, "Charles Taze Russell and the Jehovah's Witnesses, 1879-1916," American Studies 18 (Spring 1977): 57-70. Russellites began calling themselves "Jehovah's Witnesses" in the 1930s.
} 
dispossessed rural folks were drawn to Russellism because it "satisf[ied] their political, social, and emotional needs" by promising to "those who listened that their present trials would soon cease, that literally within a single day all the power and status that society had denied them would be theirs and theirs alone..." Importantly, while Russell's teachings ultimately taught that "[n]ot until the kingdom of God is established can the rights of men be properly adjusted" and no earthly political action could bring true justice, a number of Russellites did frequently endorse much of the agrarian-populist political agenda in the late nineteenth and early twentieth centuries for temporary, earthly relief and "clearly indicated where their sympathies lay.",38

Tom Adkisson, the community leader and founder of Russellism in the area, was born in Conway County in the Arkansas River Valley in 1859 to Sampson and Martha Adkisson. His parents had moved from Tennessee to Arkansas sometime before 1850 and enjoyed rising prosperity and upward mobility farming the valley's rich soils over the next decade. Between 1850 and 1860, the Adkissons saw the value of their real estate holdings rise from $\$ 500$ to $\$ 4,500$. In 1860 , they also claimed an additional $\$ 2,000$ in personal property, including two slaves, a twenty-five-year-old Mulatto woman and her two-year-old daughter, which made them one of seven slaveholding families in Muddy Bayou Township. Within a decade, however, just as young Tom began to come of age, the Adkisson family's fortune had taken a reverse course. The Civil War and emancipation appear to have leveled major blows against the Adkissons' previous economic prosperity. By 1870 , the value of the family's real estate property had

\footnotetext{
${ }^{38}$ Abrahams, "Charles Taze Russell and the Jehovah's Witnesses," 59, 63. According to Abrahams, Russell supported the nationalization of railroads, "the remonetization of silver, the single tax, the imposition of an inheritance tax, and general land reform," among other Populist measures, as well as some socialist ideas. Nevertheless, he always made clear that these could only be temporary solutions, since he believed "the union among money, politics, and religion... was too great for the poor and powerless to break." "The only real hope for deliverance, the Jehovah's Witnesses were told, lay in the millennium..." 62-64.
} 
declined by more than half to $\$ 2,000$ and the Adkissons had lost seventy-five percent of their previous personal property valuation. Sometime during the next decade, the Adkissons left their valley farm and headed north to the Ozarks to settle in the rugged hills of Van Buren County. Like many other Ozark hill farmers during this era, Sampson Adkisson joined the rising commercial timber industry in the region, undoubtedly hoping this new source of cash income would help shore up and sustain the family farm and their rural way of life, and possibly begin restoring the prosperity and upward mobility his household had enjoyed before the war. In 1880, the U.S. census listed Sampson's primary occupation as a lumberman, while Tom, now twentyone but still living with his parents, was listed as a farmer, probably assuming most of the agricultural responsibilities on the family farm. ${ }^{39}$

Sometime during the next few years Tom left his parents' home and took up residence near Rose Bud along the Cleburne-White County line. In 1887 the twenty-eight-year-old Adkisson married twenty-year-old Alice Conner of Cleburne County, and the new couple set out to start a family and make a life of their own in the rural Ozarks. ${ }^{40}$ Since the 1890 manuscript census records are no longer extant, not much is known about their lives during these years, but it was sometime during this period, as he himself later explained, when Tom encountered and accepted Russell's religious teachings. We can only speculate about Adkisson's conversion, but,

${ }^{39}$ Arkansas Gazette, July 20, 1918; Manuscript Census Returns, Seventh Census of the United States, 1850, Population Schedules, Benton Township, Conway County, AR; Seventh Census of the United States, 1850, Slave Schedules; Eighth Census of the United States, 1860, Population Schedules, Muddy Bayou Township; Eighth Census of the United States, 1860, Slave Schedules; Ninth Census of the United States, 1870, Population Schedules; Tenth Census of the United States, 1880, Population Schedules, Piney Township, Van Buren County, AR. Sampson Adkisson and his family's rising prosperity during the 1850s was typical of other families in Conway County and the Arkansas River Valley in general. Georgena Duncan, “'One negro, Sarah...one horse named Collier, one cow and calf named Pink': Slave Records from the Arkansas River Valley," Arkansas Historical Quarterly 69 (Winter 2010): 326-327.

${ }^{40}$ Ancestry.com, Arkansas, County Marriages Index, 1837-1957, [database online], (Provo, UT: Ancestry.com Operations, Inc., 2011). 
having grown up amid his family's declining fortune and difficult struggles to regain their lost prosperity and a more secure and comfortable life, despite their hard work and entrepreneurial spirit, it may be that a disillusioned Adkisson found security and relief in this doctrine that promised God would bring peace, comfort, and reward in the very near future. After all, Adkisson, in addition to experiencing firsthand his own family's struggles, was witnessing the uncertainties and confusion of Gilded Age America all around him. Railroads had begun penetrating the region, new towns popped up seemingly overnight and out of nowhere, new and strange people came while some rural neighbors were beginning to leave, and small-farm families' livelihoods became evermore connected to and impacted by distant, unpredictable national and international market forces.

For many Ozarkers like Adkisson, the new changes brought new market opportunities they hoped would set them off to a better, more prosperous future. More often than not, however, these hopes and expectations proved to be too high and too hollow for small farmers with limited resources. Most continued struggling to simply sustain their way of life and keep ahead, no matter how hard they worked or how ambitiously they sought new opportunities. Confusion and frustration frequently spawned resentment. Comments made later by Tom Adkisson during the trial following the shootout reveal a good deal about his thinking. When questioned about why the Adkisson family continued to use sugar and flour during the war despite other Cleburne County residents' patriotic pledge to only consume basic necessities such as corn meal in order to do their part for the country, Adkisson responded in typical populist language: "Lots of people don't deserve anything but corn bread, don't do anything to earn it...I 
worked and earned it." ${ }^{41}$ As Adkisson attempted to make sense of this new social and economic order, he likely found solace and inspiration in Russell's radical teachings about how the coming of God's kingdom would bring justice to those who truly deserved it within just a few years. ${ }^{42}$

By 1900, Tom, Alice, and their five young children were living on a farm of their own in Cleburne County, where Tom was running a sawmill, probably harvesting the virgin timber on his own farmstead and perhaps that of neighboring farmers and selling the lumber in local and regional markets. Since the children were still too young to labor at their father's sawmill, the Adkissons boarded two day laborers in their home, one eighteen and the other nineteen. Within the next ten years, however, Adkisson quit his sawmilling operation, probably having exhausted the biggest part of the marketable timber resources in his immediate area, at least those stands of timber that were feasible for his small operation to harvest. Perhaps more importantly, Cleburne County had undergone major social and economic changes after the Missouri and North Arkansas Railroad snaked its way through the county in 1908. The population of Heber Springs, which would become "one of the largest depots on the railroad" within a few years, more than doubled by 1910 , and the timber industry rapidly came to dominate the county's economy.

${ }^{41}$ Adkisson v. State, Transcript no. 2398, p. 226, Special Collections, University of Arkansas at Little Rock School of Law Library, Little Rock, AR.

${ }^{42}$ This, of course, is not intended to reduce religious faith and conversion to purely economic determination. Recent religious historians and sociologists have done important work to refute such simplistic explanations. Deborah McCauley's Appalachian Mountain Religion, for instance, maintains that a more nuanced "status power"- "the power of self-definition, or control over the means for creating a distinct style of life" - was far more central to mountaineers' dissenting religious culture than simple economic poverty. After all, as we shall see, the Adkisson family, at least by the standards of their impoverished local community, was relatively better-off economically than most of their immediate rural neighbors. Nevertheless, the Adkissons, like other small farmers in the Ozarks, lived in a constant state of uncertainty about the future of their rural way of life in an American society, culture, and political-economy that increasingly encouraged and rewarded urban, industrial, and capitalistic values. Their and their children's rural lifestyle and values were in jeopardy, and embracing Russell's religious teachings may have given them a sense of control and security amidst these uncertain times. According to sociologist Andrew Holden, conversion and adherence to Russellism and other millenarian beliefs "can be seen as a retreat to the certainties of fundamentalism by a people who are threatened by the loss of a stable sense of self," and such seems to have been the case for the Adkissons and their neighbors. Deborah McCauley, Appalachian Mountain Religion: A History (Urbana: University of Illinois Press, 1995), 206; Holden, Jehovah's Witnesses, 40. 
Consequently, smaller independent sawmillers such as Adkisson frequently found themselves crowded out once larger, more highly-capitalized, and more technologically-equipped operators set their sights on new timber areas that could now be harvested and shipped in profitable mass quantities by rail. By 1918 the long-idle sawmilling place on the Adkisson farm was barely recognizable, with only an old rusted boiler and decaying sawdust piles remaining. ${ }^{43}$

With Adkisson's short-lived stint in the local sawmilling business over by 1910, the federal census now listed him as a general farmer. By then Tom and Alice had eight children, and their two oldest sons, Bliss and Hardy, sixteen and fifteen respectively, were finally old enough to provide much-needed labor on the family farm. Gone were the two day laborers who had boarded with the family before, though another laborer, thirty-five-year-old Sam Bates, was living with them and working for wages on the farm. The Adkissons were clearly engaged in commercial agriculture. In 1915, Tom Adkisson owned two horses, two mules, eighteen cattle, five hogs, and $\$ 50$ worth of equipment and other personal assets, all of which was assessed at \$525 in total personal property. In 1918, Adkisson owned one horse, two mules, twenty cattle, seven hogs, and $\$ 70$ worth of equipment and other personal assets, for a total assessed valuation of \$540. In addition to selling livestock and probably other surplus farm products, the Adkissons

\footnotetext{
${ }^{43}$ Manuscript Census Returns, Twelfth Census of the United States, 1900, Mount Vernon Township, Faulkner County, AR; Twelfth Census of the United States, 1900, Piney Township, Cleburne County, AR; Adkisson v. Arkansas, Transcript, 40; Evalena Berry, "Cleburne County," Encyclopedia of Arkansas History and Culture (encyclopediaofarkansas.net); Lawrence R. Handley, "Settlement Across Northern Arkansas as Influenced by the Missouri and North Arkansas Railroad," Arkansas Historical Quarterly 33 (Winter 1974): 280-281, quotation on 281; Ronald L. Lewis, "Railroads, Deforestation, and the Transformation of Agriculture in the West Virginia Back Counties, 1880-1920," in Appalachia in the Making: The Mountain South in the Nineteenth Century, ed. Mary Beth Pudup, et al., (Chapel Hill: University of North Carolina Press, 1995), 297-316.
} 
also grew cotton as a cash crop and sold it to buyers in regional commercial centers such as Conway and Searcy. ${ }^{44}$

Like many other Ozarkers who raised livestock in numbers above subsistence levels, grew cotton as a cash crop, or sold other surplus farm products on the market, Tom and Alice Adkisson probably hoped to generate enough income to sustain the family farm and enable them to help reproduce their rural way of life for their children, six of whom had reached adulthood or were in their teens by 1918. In fact, by 1918 their twenty-four-year-old son Hardy, now married to a woman from Lonoke County and the father of an infant child, had established the modest beginnings of his own household, having built a small house on the family farm about a hundred yards from his parents' home. That year he reported four cattle, three hogs, and \$20 worth of equipment and other personal assets of his own, which amounted to a total personal property assessment valuation of $\$ 90$. Hardy continued to work on his father's farm as well. Tom's and Alice's daughter Pearle and her new husband, Leo Martin, were also working to begin their new lives together. Martin, a Tennessee native, was earning wages working for local farmer E.A. Fisher, but he and Pearle continued to live with Tom, Alice, and their younger children in 1918, a living situation that likely resulted in a denial by the local draft board when Martin requested exemption. Another daughter of the Adkissons, Ila, had also recently married into a neighboring farm family, the Simmonses. ${ }^{45}$

\footnotetext{
${ }^{44}$ Manuscript Census Returns, Thirteenth Census of the United States, 1910; Cleburne County Personal Property Tax Assessment Book-1915; 1917; 1918, Cleburne County Courthouse, Heber Springs, AR; Adkisson v. Arkansas, Transcript, 222.

${ }^{45}$ Personal Property Tax Assessment Book-1918; Leo Martin World War I draft registration card, Cleburne County, AR, available at Ancestry.com; Adkisson v. Arkansas, Transcript, 138, 214, 224-225.
} 
The odds seemed to be stacking higher and higher against these families and other small farmers throughout the Ozarks, especially for this next generation. In 1918, though, farm prospects seemed to be looking better, as wartime demand drove up the prices of American farm products in international markets. If the government would only leave them alone, many must have believed, this might finally be the chance to improve their families' prospects in the rural Ozarks. But the interests of privileged, ungodly elites seemed to be standing in their way once again. This probably came as no surprise to the Adkissons. The Bible plainly told them, after all, that the privileged and ungodly of the world would reap their reward on earth but not in heaven; the righteous and just, on the other hand, would endure longsuffering in this dispensation before inheriting the Kingdom of Heaven in the next.

The Adkissons' neighbors and co-religionists undoubtedly shared this frame of mind as well. Despite their own struggles, the Adkissons owned more property and were better-off economically than most of their impoverished neighbors, such as the Sweeten and Simmons families. In 1918, E.J. “Jack” Sweeten, whose son Amos had deserted from Camp Pike in Little Rock and was also evading authorities by the summer, owned two horses, two cows, two mules, seven hogs, and \$25 dollars worth of equipment and other personal assets, for a total personal property assessment of $\$ 200$, which was $\$ 340$ less that Tom Adkisson's personal property. Similarly, Matt Simmons, who would be Tom Adkisson's son-in-law and fellow draft evasion accomplice by the time of the altercation with authorities in 1918, owned no horses, one mule, four cattle, one hog, one ten-dollar wagon, and \$20 worth of equipment and other personal assets, for a total personal property valuation of only $\$ 120$. Despite the small size of his farming operation, Simmons, like most small farmers in his neighborhood, grew cotton as a cash crop and 
probably sold other surplus farm products on the market. ${ }^{46}$ Sweeten, Simmons, and other poor hill farmers in the community may also have supplemented their meager farm incomes with parttime timber work or seasonal jobs. Merely scraping by, however, was typically about all they could muster. Adkisson's faith in Russellism apparently appealed to several of these neighbors. The signs of society's injustices and decay and the earthly chaos that Russell had long spoken of as prerequisites of the End Times were all around, and soon, they were convinced, the righteous would have their just reward.

It is unclear how Adkisson went about spreading his radical faith in the area. Many conversions to Russellism undoubtedly were the consequences of intermarriage with the Adkisson family, which may have also won over some extended family members. The number of Russellite Christians in the area is unknown, but press reports on the shootout and the subsequent manhunt indicate that adherents probably numbered more than just the Adkissons and their extended family networks. Indeed, their religious community had apparently grown large enough by 1918 that they had brought in a new Russellite preacher, former Baptist preacher Houston Ausburn, and his family of nine to minister to this community's flock of believers.

Others in the area probably adopted the faith through their local economic and social interactions with the Adkissons. In 1903 Russell's organization, then headquartered in Allegheny, Pennsylvania, commenced its campaign of door-to-door evangelism and tract distribution that would come to characterize the Jehovah's Witnesses, so perhaps Adkisson and his Russellite brethren may have been employing these aggressive tactics during the years preceding World War I—tactics that may have been unwelcome and irritated some Cleburne County residents. If

\footnotetext{
${ }^{46}$ Personal Property Tax Assessment Book-1918. Sweeten resided in neighboring Cadron Township.
} 
this was the case, however, Adkisson or his co-religionists do not appear to have been stigmatized in the area as dangerous or overly-obnoxious religious radicals before the draft resistance affair. During the subsequent trial, in fact, several prominent citizens and political officials in the area, including some Heber Springs residents, testified that they had long been acquainted with Adkisson and vouched that they had generally known him to be "all right, quiet, peaceable and honest, and a good fellow" before the draft incident. ${ }^{47}$

The only big question to emerge in the case regarding Tom Adkisson's reputation appears to have been his thirst for the hard stuff, a crack in Adkisson's armor that the prosecution hoped would cast some doubt on his personal character during the trial. Several of those witnesses who testified about Adkisson's solid reputation admitted that "he used to drink right smart," though most qualified their statements by adding that Adkisson's occasional drinking sprees and rowdiness were nothing particularly out of the ordinary and that he had simmered down a good bit since his younger days. Adkisson himself confessed that he had "paid a few fines for being drunk" years ago but insisted that he had not "ordered any whiskey I reckon for ten years" and had "quit before the bone dry law came" to Cleburne County when he decided "it was best for me too." In 1906 Adkisson was arrested and subsequently pleaded guilty on charges of disturbing the peace. Unfortunately, since most of the case files are no longer extant for Cleburne County civil and criminal matters before 1917, the nature of Adkisson's offense is unknown, though it probably involved one of these drunken escapades. Co-religionist Columbus Blakey was likewise arrested and convicted of disturbing the peace in 1915, despite a non-guilty plea, and he was indicted again, along with Harry Potey, in 1915, though the specific charges

\footnotetext{
${ }^{47}$ Beckford, The Trumpet of Prophecy, 9; Adkisson v. Arkansas, Transcript, 158-170, quotation on 166.
} 
were not recorded in the docket and the case was apparently dropped by the following term. ${ }^{48}$ It is possible that Adkisson and his neighbors may have already ruffled some feathers in the area by 1918, but their religion does not appear to have branded them as dangerous undesirables before the conflict over draft evasion arose.

Nevertheless, some Cleburne County town dwellers, particularly in Heber Springs, harbored intolerant attitudes toward dissenting people and opinions during the late nineteenth and early twentieth centuries, as did many of their counterparts throughout a rapidly changing America. A couple of conflicts between the town's "better sorts" and dissenters in the area, aside from the local "draft war" in 1918, in fact, made national news. Even before the railroad finally came to transform the town in 1908, Heber Springs prided itself on being a lively, progressive tourist attraction built around the area's beautiful natural springs that had become popular health spas back in the 1880s. Local businessmen, boosters, and residents worked diligently to build and protect their town's New South image, especially at a time when the Ozarks and Arkansas, like Appalachia back east, had increasingly become associated with the “dim-witted hillbilly and the noble hillman" in America's popular consciousness. ${ }^{49}$

Russellism was not the only "strange sect" to crop up during this era in Cleburne County that threatened this respectable image. The New York Times reported back in 1897 that a "state of panic" had arisen among the town people of Heber Springs over the rise of a new movement of radical dissenting Christians in the area who referred to themselves as "The Order of Holiness." "The carousals of the holiness camp shocked the community," the paper reported, and

\footnotetext{
${ }^{48}$ Adkisson v. Arkansas, Transcript, 154-173, 216;Cleburne County Circuit Court Docket, Book 4; Book 5, Cleburne County Courthouse.

${ }^{49}$ Blevins, Arkansas/Arkansaw, 73.
} 
alarmed Heber Springs residents sought to suppress these "crazed" people and their teachings, even with the use of local law enforcement. ${ }^{50}$ Many townsfolk in Heber Springs also proved ready to stamp out those who dissented against the political and economic ideals of town "progress," even through extralegal means, especially after the town hit a new growth spurt and became a major railroad center in the region. On a cold January night in 1923, less than five years after the draft resistance affair, a self-appointed "citizens' committee," which had been formed to supplant those in their county suspected of participating in or sympathizing with the Great Railroad Strike that had swept the nation, captured two men, whipped them, and ordered them to leave the area. This act and other "investigation[s]" and "question[ing]" by the "citizens committee" proved successful, according to the New York Times, since "virtually every striker or strike sympathizer was reported to have either left that vicinity or was preparing to leave." 51 Like other boosters and residents in budding towns in the region, Heber Springs townsfolk were not about to allow their town's and county's reputation to be called into question and risk ruining their ongoing quest to become the New South's next success story.

Thus, when the United States went to war in 1917, local businessmen and officials in Heber Springs determined not only to do their part but to demonstrate an exceptional commitment to this national cause, and no "slackers" refusing to comply with the U.S. government's military conscription would dare spoil their mission. As Jeannette Keith explains, "Mobilization put considerable if unspecified power into the hands of members of the town elites," and sincere patriotism was frequently blurred with economic boosterism. ${ }^{52}$ A number of

\footnotetext{
50 “Strange Sect in Arkansas,” New York Times, September 6, 1897.

51 "More Flogged in Arkansas: Two Men are Reported Whipped by Mob at Heber Springs," New York Times, January 21, 1923.

${ }^{52}$ Keith, Country People in the New South, 152.
} 
men who joined the local citizens' posses in Heber Springs and the nearby towns of Searcy, Pearson, and Quitman to hunt down the Adkissons and the other draft resisters, not surprisingly, were local businessmen and professionals. S.A. Turner, for instance, one of the original four possemen who accompanied Sheriff Duke to arrest the draft resisters and took part in the initial shootout, was a physician in Heber Springs. Porter Hazlewood, the posseman who was killed in the shootout, may have been an aspiring gunsmith or a firearms dealer in town, though he appears to have been quite poor since the only personal property he reported in 1917 was $\$ 10$ worth of firearms. J.R. Chesbro, who joined Sheriff Duke's posse for the second shootout at the Adkisson farm, was a town merchant whose entrepreneurial ambition landed him a conviction and a \$10 fine for selling cigarettes illegally during the same term of court as the Adkisson trial. The leader of one posse during the manhunt, Arthur Frauenthal, a thirty-two-year-old jewelry salesman in Heber Springs, was also the chairman of the County Council of Defense, which had been created to promote and help organize the war effort and suppress "slacking." Frauenthal, ironically, was the son of a German Jewish immigrant, the late Max Frauenthal, a prosperous merchant, a Confederate veteran, and the founder of Heber Springs and Cleburne County. In addition to his stake in boosting and guarding the town's image, Arthur Frauenthal may also have been self-conscious, despite his prominent standing among local elites, about leaving any doubts regarding his unwavering allegiance to the Red, White, and Blue in the fight against his "dreaded Hun" kinfolk across the pond. ${ }^{53}$ For these men and other local boosters like them in the area filled with the patriotic spirit, it was their time to shine and prove all of those naysayers out

\footnotetext{
${ }^{53}$ Manuscript Census Returns, Thirteenth Census of the United States, 1910, Population Schedules, City of Heber Springs, Cleburne County; Personal Property Tax Assessment Book-1918; Jeannie Frauenthal, "Max Frauenthal (1836-1914)," Encyclopedia of Arkansas History and Culture (http://www.encyclopediaofarkansas.net/encyclopedia/entry-detail.aspx?entryID=3184).
} 
there that their town, county, region, and state were just as progressive as the rest of Americaindeed, "100\% American." The Adkissons and their neighbors would pay for their un-American "slacking" one way or another.

By late Sunday afternoon on the day of the shootout at the Adkisson farm, over 100 armed men were combing the woods for the draft resisters and their supporters, and this number grew over the next couple of days to more than 200 as additional officers, volunteers, and a contingent of National Guard troops armed with machine guns sent by Governor Brough arrived. Local officials and town elites even petitioned Governor Brough to declare martial law. ${ }^{54}$ Family members and neighbors suspected of sympathizing with or aiding the draft evaders were arrested and taken to a hotel in Heber Springs for questioning and safe-keeping by authorities. Among those arrested were Ila Simmons and Pearle Martin, the daughters of Tom Adkisson and wives of draft evaders, who claimed they, their family, and neighbors were loyal Americans but “conscientious objector[s] to war." Fearing for the lives of the draft evaders, Ila and Mrs.

Blakey, the mother of three draft resisters, convinced federal officials to allow them to attempt to contact the evaders and try to persuade them to surrender, though their efforts to meet with them were unsuccessful. Authorities also arrested Russellite minister Houston Ausburn and his large family, after they found him hiding under the floor of his home. Ausburn was suspected of being a primary instigator in the affair, since he was discovered to have been preaching that the "world is coming to an end as a result of the world war, and that all men participating in the conflict will

\footnotetext{
${ }^{54}$ Jeanette Keith finds that many Southern elites demanded outside government intervention when faced with local draft resistance and suggests that this fact, perhaps, should call into question the sincerity of the Southern creeds of states' rights and local control, and even white supremacy. She asks: "Were white southerners loyal to states' rights and white supremacy as a matter of principle, or expediency? Were states' rights and white supremacy things that mattered intrinsically to white southerners, or merely slogans used to cloak the things that really mattered? When war mobilization presented southern white elites with the necessity of deciding whether to stand by states' rights and white supremacy, or to further other interests, what did they choose?" Keith, Rich Man's War, Poor Man's Fight, 8.
} 
be doomed to eternal hellfire, that those who do not engage in war will be spared and that therefore men should not put on a uniform. ${ }^{, 55}$

Jack Sweeten, the father of two draft resisters, was also arrested, but he promised officials that he knew the whereabouts of one of his sons, Amos, who had deserted from Camp Pike, and would talk this son into surrendering if they would release him. But when Sweeten returned to Heber Springs that night without Amos, several angry members of a search posse seized him and "threatened to lynch him." Luckily for Sweeten, one of the possemen intervened to prevent the lawless act. But news of the old man's harsh treatment somehow quickly reached his son, and Amos rushed to town to turn himself in about an hour after midnight. Amid the "feeling of intense indignation" among several of the possemen and the potential for "mob law" when Amos arrived in town to surrender, he and his father were quickly escorted to the county jail. ${ }^{56}$

Meanwhile, as many heavily-armed possemen, lawmen, and soldiers hunted for the hidden draft evaders, others worked to "dry up" any sources of supplies, food, or shelter that might assist the "slackers," searching and closely guarding the homes of family members and neighbors in the vicinity of the Adkisson place. Ultimately, this plan to isolate and squeeze the resisters out of their wooded hideouts and into submission succeeded, though it took significantly longer than officials expected. Four days after the shootout, George Burleson and his step-son were spotted by authorities walking along a dirt road near Rose Bud and were subsequently captured. Burleson was said to have been carrying a copy of The Finished Mystery, the volume

\footnotetext{
${ }^{55}$ Arkansas Gazette, July 10, 1918; ibid., July 11, 1918; ibid., July 13, 1918; ibid., July 20, 1918; Willis, “The Cleburne County Draft War," 32-34.

${ }^{56}$ Willis, “The Cleburne County Draft War,” 31-32; Arkansas Gazette, July 9, 1818.
} 
of Charles Taze Russell's writings published after his death in 1917 that had been banned by federal authorities. The book had been condemned by a federal judge as more dangerous than "a division of the German army" because of its denouncements of patriotism, war, and "civil governments of the earth" that rule in contradiction to "the law of heaven." ${ }^{.57}$ The next day, the National Guard troops and other lawmen conducted their most thorough search of the area yet, and Faulkner County Sheriff W.W. Bishop accompanied prisoner Ila Simmons and her Uncle Tobe Adkisson, who had recently arrived from Conway, as they drove through the area in an automobile in hopes of finding their kinfolk to try to convince them to surrender. But the Adkissons and their fellow draft resisters remained at large. ${ }^{58}$

The following day, in fact, the National Guard unit packed up its machine guns and returned to Little Rock. But local law enforcement and the citizens' posses remained determined in their search efforts and the patrolling of the homes and properties of suspected sympathizers. One fatigued draft resister, Tom Adkisson's son-in-law Leo Martin, who told officers he was "tired of being hunted," finally surrendered that Saturday morning in White County and was jailed in Searcy. On Sunday, after surviving for a week on only water and peanuts, four more draft resisters, Jim, Jess, and Columbus Blakey and John Penrod, turned themselves in to the Searcy-Judsonia Home Guard at Rose Bud. Bliss Adkisson then surrendered at the same place the following day. Finally, on Tuesday—nine days after the incident—Hardy Adkisson turned himself in at Cabot in Lonoke County, and Tom Adkisson went to Conway in Faulkner County to give himself up, where he told authorities that he and the others would have surrendered to

\footnotetext{
${ }^{57}$ Arkansas Gazette, July 9-12, 1918; Willis, "The Cleburne County Draft War," 30, 34-35, n 41.

${ }^{58}$ Arkansas Gazette, July 13, 1918.
} 
federal officials earlier had it not been "for fear the other [local civilian] mob would cut us off."59 With Tom Adkisson's arrest, the manhunt for draft resisters in Cleburne County and the surrounding area ended.

As the spectacle of draft resistance in Cleburne County drew to a close, observers weighed in to explain the reasons behind the Adkissons' and their neighbors' stubborn and purportedly unreasonable defiance against the government's draft. Charles T. Davis of the Arkansas Gazette, in a lengthy newspaper article on July 14, attributed the Cleburne County hill folks' resistance to their backward rural mountain culture:

To one who sees the mountains from afar off it would seem that the mountain people should be God's chosen people, that their souls should be great with the vast distances they view, and their hearts in harmony with the marvelous beauties of nature... But this is not so. It is not so in the Swiss Alps, nor the Balkan mountains, nor the Himalaya piedmonts, nor the Ozark foothills. Geographically the mountains have always bulked against the progress of industrial advancement, and sociologically their people have always stood against the forward movement of national betterment. There are probably many reasons, not the least of which is the law of heredity.

The "Heritage" of the hill folks' pioneer "ancestors," Davis explained, was fully preserved "in the sanctuary of the mountains," so mountaineers even in the twentieth century "still carry an inborn hatred of the law, inbred and interbred through generations." Isolation had created among mountain folks "a simple inability to comprehend...the primal causes of the law, the changed

\footnotetext{
${ }^{59}$ Ibid, July 13-17, 1918; Willis, “The Cleburne County Draft War,”36-37.
} 
conditions which made it necessary." Shielded from the progress of the outside world, Davis continued, the Ozarker had long been "afflicted with a mental myopia." "Out there lies a big land, he knows, but its existence affects him little. He limits his gaze to the close drawn horizon of the hills which gird him round and he cannot vision the high, ineffable stars nor that which lies beneath beyond. ${ }^{\prime 60}$

Ultimately, since these inherently law-defying mountaineers had "little sense of any geographical limits more than purely local," Davis argued that "the very limitations of their information render them an easy prey to fanatics or renegades of their own people who take up the preaching of sedition under the guise of religion," such as "the subtle, sapping dogmas of the Russellite[s]." Yet Davis's use of mountain stereotypes and rural parochialism to diagnose the Cleburne County affair proved overly simplistic, even among at least some federal officials. During the aftermath of the shootouts and the subsequent hunt for the draft evaders, a Major Brandon of the Fourth Arkansas National Guard unit conducted an official federal investigation of the incident and, in shifting at least part of the blame to the local draft board and lawmen, concluded that the whole affair might have been avoided if local authorities had been more sensitive to the draft resisters' religious objections and taken care to inform them of the noncombat alternatives that were available. Ironically, federal authorities seemed to demonstrate more empathy for the local rural resistors than local administrators did. ${ }^{61}$

Despite Major Brandon's findings, which were issued in early August, a federal court martial sentenced four of the deserters, Jesse and Columbus Blakey, John Penrod, and Leo

\footnotetext{
${ }^{60}$ Charles T. Davis, "Why the Dwellers in the Cleburne County Hills Fight Against the Draft," Arkansas Gazette, July 14, 1918.

${ }^{61}$ Ibid; Willis, "The Cleburne County Draft War," 39.
} 
Martin, to five years of hard labor in the military barracks at Fort Leavenworth, Kansas, in addition to a dishonorable discharge once their time was up. Several of the draft resisters were also indicted by the circuit court in Cleburne County on charges ranging from assault to kill to first degree murder. The Adkissons, of course, received the harshest sentences. A jury convicted Bliss Adkisson of second degree murder for the killing of posseman Porter Hazlewood and sentenced him to an eighteen-year prison term. The defense appealed the case to the Arkansas Supreme Court, which upheld the lower court's decision, and Adkisson was imprisoned at Little Rock. During a jailbreak in September 1921, an escaping inmate killed Bliss Adkisson, who was pulling guard duty. Patriarch Tom Adkisson received a voluntary manslaughter conviction and a two-and-a-half-year prison sentence, and a jury also found Hardy Adkisson guilty of the same charges and gave him two years behind bars. Governor Thomas McRae paroled Tom Adkisson in May 1921 for good behavior but then "ordered his re-arrest and return to prison" the next month when the American Legion of Arkansas and its local members "protested vehemently" against the "slacker's" release. ${ }^{62}$

The drama in Cleburne County was not the last explosive encounter between rural draft resisters and authorities in the Arkansas Ozarks. While the Adkissons awaited their trials and sentencing in jail, another incident of armed draft resistance broke out over a hundred miles to the northwest, deep in the heart of the Boston Mountains - the most rugged subregion in the Arkansas Ozarks - in the Cecil Cove community near Erbie and Wilcockson in Newton County.

\footnotetext{
${ }^{62}$ Arkansas Gazette, August 21, 1918; State v. Matt Simmons, Jess Blakey, Columbus Blakey, and James Blakey, case no. 269; State v. Leo Martin, Jno Penrod, and Thos. Adkisson, case no. 271; State v. Bliss Adkisson, et al, case no. 272; State v. Tom Adkisson, Bliss Adkisson, and Hardy Adkisson, case no. 273, Spring 1919; State v. Hardy Adkisson, case no. 379, Fall 1920, Cleburne County Circuit Court, Cleburne County Courthouse; Adkisson v. State, 142 Ark. 15, January 26, 1920; "Slays Guard, Wounds 2 but Fails to Escape," New York Times, September 19, 1921; "Legion Protests Parole of Slacker, Prisoner Returned," Laurel Daily Leader (Mississippi), June 22, 1921.
} 
(The latter locale was the future home of Dogpatch, U.S.A., a large theme park founded in 196768 and based on Al Capp's popular hillbilly comic strip). There in a long and narrow holleramid "nearly impenetrable mountains, ravines and tangles of timber and underbrush" that, according to one newspaper, would "fill a stranger's soul with trepidation"-local and federal authorities estimated that as many as thirty-six draft evaders and their family members had organized in armed defense and signed a "covenant" to resist the draft. Several young men in the Cecil Cove area called up by the Selective Service were already eluding authorities by September 1918. But the "belated call" to Arthur Keeton, the son of Bill Keetoncommunity's former justice of the peace and, ironically, a member of the local draft boardappears to have precipitated the resisters' collective action. Arthur Keeton, whose draft registration card was signed by his own father, had requested exemption because he carried the mail for the U.S. Postal Service in his neighborhood. Either the other members of the local board in the county-seat town of Jasper or their superiors in the Selective Service, however, had apparently overruled Arthur's exemption by September. ${ }^{63}$

Newton County Sheriff W.J. Pruitt made preparations to raid and arrest the "Cecil Cove Slackers" but decided against risking the lives of his deputies, possemen, and himself when, according to one newspaper report, he received a threatening notice from the draft resisters to “Come on, but look out for yourself” and learned that the evaders had a clear tactical advantage, positioned high and well-fortified in the cove's steep mountainous terrain. Indeed, a few outspoken proponents of the war in the vicinity of Cecil Cove also reported that they too had

\footnotetext{
63 "How the Hill Billies of Cecil Cove Defied Uncle Sam," Kansas City Star, February 19, 1919; "Draft Evaders are to Surrender," Arkansas Gazette, September 25, 1918; Arthur Keeton World War I draft registration card, Cleburne County, AR, available at Ancestry.com (accessed December 23, 2012).
} 
been threatened by the draft resisters. Joe McFerrin, who lived just outside the community, had become concerned about some of his cattle that were feeding on the open range in the cove but was warned by the evaders not to "come down to look after "em." The resisters also rounded up "a drove of hogs" owned by Levi Smith, a merchant in the small town of Compton, and returned them during the night to his place, where they left him notice that "You don't need to come down into the Cove." Another resident of the area, Alex Biggs, a farmer and an itinerant preacher who championed the U.S. war effort, wound up leaving the community altogether because of his neighbors' anti-war positions, stating that "I couldn't stay there and think the way I do." ${ }^{64}$

Perhaps the most serious threat, however, was directed at "Uncle Jimmy" Richardson, a farmer and the preacher at the Chapel Church just west of the cove. A Confederate veteran who had migrated to the Ozarks from central Tennessee sometime during the last two decades of the nineteenth century, the elderly Richardson was an avid and patriotic supporter of the U.S. war effort who openly condemned the "gang of yellow bellies" in Cecil Cove. Richardson had aggressively chastised some of the draft resisters' fathers, telling them: "If you got any manhood in you them boys will be made to go serve their country." Richardson's comments, not surprisingly, were not received kindly in the cove as thoughtful, neighborly advice. When he traveled into the cove one day, Richardson claimed that a concealed gunman fired at him, the shot coming so close that "the bullet whistled past his ear." "In the old days of the Civil War," he told a newspaper reporter, "them kind was swung up to the nearest tree." Frustrated with the lack of other locals' efforts to confront "the cowardly hounds," Richardson complained: "I'm 73

\footnotetext{
64 "How the Hill Billies of Cecil Cove Defied Uncle Sam."
} 
now, but I'd have got down my rifle and gone in with anybody that would have went after them. I don't like to live near folks who ain't Americans.” By 1918, this old Confederate had become "100\% American." 65

By the middle of September, local authorities pleaded with U.S. officials to declare martial law in their county and begged federal lawmen and military personnel to come deal with the draft resisters. A frustrated Colonel Mark Wheeler, the second-in-command at Camp Pike in Little Rock, met with local authorities and federal marshals in Jasper and threatened that "if you fellows don't round these men up soon I think we'll let our boys come up and clear out these slackers. They would like the job." But after carefully assessing the situation, federal authorities determined that "it would take a regiment of soldiers months to comb the country, which is so rough that...[it is] doubt[ful] the search could be undertaken with horses." Perhaps more importantly, federal officials agreed with Deputy U.S. Marshal Jim Holt who said that an attempt to arrest the draft resisters would be "nothing short of suicide." 66

Ultimately, the U.S. War Department directed federal and local authorities to attempt to negotiate with the "Cove gang" and assure them that desertion charges would not be filed if they surrendered peacefully. According to locals interviewed by a newspaper reporter after the affair ended, federal authorities also promised the draft resisters that they would arrange it so that the young men would be "gone only from sixty to ninety days, [and] that they would all get a suit of clothes and a dollar a day." In the meantime, local Newton County political officials had sworn in a new sheriff, Frank Carlton, who had been born and raised within five miles of Cecil Cove,

\footnotetext{
${ }^{65}$ Ibid.; Manuscript Census Returns, Ninth Census of the United States, 1870, and Tenth Census of the United States, 1880, Population Schedules, District 18, Rutherford County, TN; Twelfth Census of the United States, 1900, Population Schedules, Grant Township, Newton County, AR.

66 "How the Hill Billies of Cecil Cove Defied Uncle Sam"; "Draft Evaders are to Surrender."
} 
had taught school in the area, and was well-acquainted with many of the families who lived there. Sheriff Carlton was confident that he could convince the draft resisters to surrender and went to the cove to meet with some of their family members. Carlton promised that he would come alone and unarmed to meet the deserters and arranged to have them surrender at a remote crossroads, also assuring them that only he, unarmed and with no other lawmen accompanying him, would escort them to the military base at Camp Pike. The draft evaders agreed, and the potentially explosive affair ended quietly and peacefully. "Uncle Sam’s Little War in the Arkansas Ozarks," as the Literary Digest labeled the Newton County incident, in fact, had ended with only one casualty; one draft resister's twelve-year-old brother who had been traipsing through the cove was mistaken as a lawman and shot in the left leg by the friendly fire of an unknown evader. $^{67}$

Despite its anticlimactic ending, this story of "How the Hill Billies of Cecil Cove Defied Uncle Sam" drew the attention of the Kansas City Star's yellow journalism mill, which tended to keep a watchful eye on its peculiar mountain neighbors to the south for scoops that could be whipped up into sensational stories. ${ }^{68}$ The Star found it amusing that "Cecil Cove, in the most remote fastness of the North Arkansas Ozarks, baffled the United States government where the Wilhelmstrasse failed at the job." "Bernstorff, Von Popen, Dernburg and their like couldn't fool Uncle Sam's agents," the paper remarked, “but [the cove's] old Lige Harp and their boys could

\footnotetext{
67 "How the Hill Billies of Cecil Cove Defied Uncle Sam"; "Uncle Sam's Little War in the Arkansas Ozarks," Literary Digest, March 8, 1919, 107-111. The Literary Digest article was essentially a reprint of the Kansas City Star newspaper article.

${ }^{68}$ On Kansas City newspapers, including the Kansas City Star, and their sensational coverage of the bizarre Connie Franklin murder story in Stone County, Arkansas, in the winter of 1929 and their "irresponsible treatment of a place and people" through "stereotypes and preconceived notions," see Brooks Blevins, "The Arkansas Ghost Trial: The Connie Franklin Case and the Ozarks in the National Media," Arkansas Historical Quarterly 73 (Autumn 2009): 254-271, quotations on 271; and Brooks Blevins, Ghost of the Ozarks: Murder and Memory in the Upland South (Urbana: University of Illinois Press, 2012), 2, 9, 28-29, 37, 38, 156, 157, 160, 232n12.
} 
and did." Framing the story with typical mountain stereotypes, the paper commented that "[t]ime swings far backward" in this rugged and isolated mountain community:

The little log cabins that house families of eight and ten seem to belong to another era. Hogs, dogs, cats, chickens, geese, turkeys and children run riot in, around and through these houses. Rifles of several stages, from the long-barreled muzzle-loader to the most modern repeater, hung above the open fireplaces. Corn pone, corn fed hogs and sorghum molasses are the culinary standbys. "Pa and Ma" and the majority of the kids smoke corncob pipes, sometimes use snuff and always are unerring spitters. The youngest of the family is considered deserving of a reprimand if he cannot hit the fireplace at ten paces. The mountain folk are suspicious of strangers and are exceedingly reticent in their presence, but are peculiarly hospitable. It is something akin to an insult if the wayfarer does not stop and partake in their hospitality, but he will find difficulty in getting questions answered.

The clannishness of these mountain people and their primitive intimacy with the forbidding terrain, in fact, were what enabled them to elude one of the most powerful and resourceful governments on the planet, the Star explained. Since "news travels by strange and devious processes in the mountains"-ironically, considering the paper's suggestion that the community was frozen in time, the pervasive use of telephones proved especially useful—-through close-knit family networks, the draft evaders were always informed the minute a stranger set foot in the cove and were able to escape, hide out, and prepare an armed defense in rocky crevices, caves, and dense forests before even the most skillful marshal or deputy could make his move. The paper also suggested that the mountain man's peculiar physical characteristics gave him an 
advantage over the authorities: "Bent forward, walking with characteristic shuffle, he can scurry over boulder and fallen log like an Indian." ${ }^{, 69}$

"What caused the rebellion in Cecil Cove?" the Star asked. "A combination of plain ignorance, Jeff Davis politics, the Appeal to Reason, and mountain religion," it explained. The paper preferred to portray these hill folks with typical mountain stereotypes and caricatures and their resistance against the draft as backward and irrational, but, despite its clear lack of empathy, it was closer to the mark in pointing out their political and religious dissent. "Same stuff that Jeff Davis created about all those years the 'hill billies' were electing him to the United States Senate...He is dead now, but his teachings live in the activities of these mountain people," the paper remarked. "Uncle Lige" Harp, a small farmer and one of cove community's patriarchs, told a reporter that "We didn't have no right to send folks over to Europe to fight; tain't a free country when that's done. Wait till them Germans come over here and then fight 'em is what I said when I heard 'bout the war. If anybody was to try to invade this country ever man in the hills would get his rifle and pick 'em off."

Getting involved in a foreign war probably made even less sense to Harp and his family since sending their son Wesley and the other young men in the community off to serve in the military also brought increased burdens upon their small farm families. The son of an antebellum-era Ozarks pioneer and Union veteran of the Civil War, Lige Harp was born around 1860 and appears to have never ventured far from his Newton County birthplace. He and his family entered the twentieth century toiling to eke out a living on their small farm in Cecil Cove. By 1918, with the oldest two sons having already set out on their own and left the community, an

\footnotetext{
69 "How the Hill Billies of Cecil Cove Defied Uncle Sam."
} 
aging Harp depended upon the farm labor of his twenty-five-year-old son Wesley to help support the family, especially since his teenage son Garrett appears to have had a disabling mental illness and his youngest son was only about nine years old. The government's orders for Wesley to report for military service, then, would have been particularly burdensome, if not downright devastating, for the Harp family, just as it was for other small farm families experiencing similar situations. $^{70}$

Practical troubles also mixed with deep religious convictions to rally resistance against the draft in Cecil Cove. The community's religious leader, Holiness preacher and farmer George Slape, contended that “the good book says: 'Thou shalt not kill.' We didn't want our boys takin' nobody's life. It ain't right 'cause it's contrary to the Bible and the good Lord's teachin's." When a newspaper reporter questioned Slape about the draft evaders' seemingly contradictory behavior in violently taking up arms against federal and local authorities, Slape responded: "The boys wasn't goin' to kill nobody unless they had to. It's different killin' a man who tries to make you do wrong and killin' somebody in war."

Slape and his family were also leading agrarian Socialists in the community. The son of a small farmer and Confederate veteran, Slape was born in Boone County, Arkansas, around 1855, though, unlike the Harps, he and his family were quite mobile throughout the following

\footnotetext{
${ }^{70}$ Manuscript Census Returns, Seventh Census of the United States, 1850, Population Schedules, Van Buren Township, Newton County, AR; Eighth Census of the United States, 1860, Ninth Census of the United States, 1870, and Tenth Census of the United States, 1880, Population Schedules, Mill Creek Township, Newton County, AR; Twelfth Census of the United States, 1900, Thirteenth Census of the United States, 1910, Fourteenth Census of the United States, 1920, and Fifteenth Census of the United States, 1930, Population Schedules, Grant Township, Newton County, AR; Elijah Harp Service Record, American Civil War Regiments (Ancestry.com online database); James Wesley Harp World War I draft registration card, Newton County, AR, available at Ancestry.com. Census records reveal that Garrett Harp could not speak English and, in 1930, twenty-seven-year-old Garret continued to live with his elderly parents and was listed as "son inv [invalid]" on the census form.

71 "How the Hill Billies of Cecil Cove Defied Uncle Sam"; Tina Farmer interview with author, September 19, 2012.
} 
decades. In 1877 Slape married a local woman, Mary, and they settled on a small farm of their own and began raising a family in the same county. By 1900, the family, now with eight children, had moved a few miles south to a new farm in neighboring Newton County. But sometime during the next decade, the Slapes, including their oldest daughter Rosa's and her new husband Thomas Edwards's young family, migrated west to Cherokee County, Oklahoma, where they farmed as tenants and wage hands and probably became involved in the growing Socialist movement. During their time in the Sooner State, another daughter, Elsia, married Georgia native, Oklahoma farm laborer, and fellow Socialist Jim Blackwell, and they, too, began raising a family. The Slapes, Blackwells, and Edwardses left Oklahoma sometime between 1910 and 1918 and returned to the Cecil Cove area, probably hoping to reclaim some independence back home in the rural Ozarks. The Slapes rented a house north of the cove in Boone County, where George apparently farmed his own land and preached at the local church in Cecil Cove. The Blackwells and their young children lived with the Slapes and worked on the family farm, while the Edwardses settled and farmed a place of their own in the vicinity of the cove in Newton County. When questioned about why they and the other young men in the area resisted the draft, Jim Blackwell and his friend France Sturgil— "who [were] reputed to have been the circulators of the covenant [to defy the draft]" and to "have read scattering copies" of the Appeal to Reason, the prominent Socialist newspaper published in Girard, Kansas - explained that they and the other families in the cove believed the government's military conflict was an unjust "war for the benefit of them silk hated [sic] fellers up in New York." "We don't want our boys fightin' them rich fellers' battles and gettin' killed just to make a lot of money for a bunch of millionaires," they explained. "Why they own most of the country now." 72

\footnotetext{
${ }^{72}$ Manuscript Census Returns, Seventh Census of the United States, 1850, Population Schedules, unlisted township,
} 
The rural Ozarkers who resisted the U.S. government's military conscription, then, did so because the draft imposed increased burdens upon already struggling small farm families and violated their populist sense of justice, fairness, and morality. Selective Service policies often adversely impacted small family farmers and their communities, and, despite efforts to localize much of the decision-making through local draft boards, they ensured that town and county elites controlled the process and that the problems and needs of poor and middling backcountry folks went neglected. Rural draft evaders in the Ozarks were not isolated anti-government parochials. Far from it, many were agrarian Socialists and populist-progressives who championed an expansive government to coral the excesses and injustices of free-market capitalism. Yet they despised how the moneyed interests exploited their privileged access to government power to organize and conduct a "rich man's war" with "a poor man's fight."

The struggles of small farmers in the Ozarks backcountry continued after the First World War, as did populist resistance against government policies that seemed to favor "elites" and "special interests" at their expense. The ultra-patriotism of the World War I years and the Red Scare hysteria that followed, which spawned overzealous efforts to purge dissenters deemed "unAmerican," however, stigmatized more radical expressions of populist resistance in the region's rural backcountry, just as they did throughout the rest of America. When a young Independence County hill farmer, J.W. Scoggins, for instance, sat on the stand in a courtroom in 1922 to defend

Marion County, AR; Eighth Census of the United States, 1860, and Ninth Census of the United States, 1870, Population Schedules, Washington Township, Boone County, AR; Tenth Census of the United States, 1880, Population Schedules, Blythe Township, Boone County, AR; Twelfth Census of the United States, 1900, Population Schedules, Richland Township, Newton County, AR; Thirteenth Census of the United States, 1910, Population Schedules, Crittenden and Hubert townships, Cherokee County, OK; Fourteenth Census of the United States, 1920, Population Schedules, Bryan Township, Boone County, AR, and Plumblee Township, Newton County, AR; John A. Slape Pension Records, Arkansas, Confederate Pension Records, 1891-1935 (Ancestry.com online database); G.W. and Mary A. Slape Record of Marriage, July 19, 1877, Arkansas County Marriages Index, 1837-1957

(Ancestry.com online database); "How the Hill Billies of Cecil Cove Defied Uncle Sam." 
himself against murder charges, the prosecuting attorney found it useful to bring up the fact that Scoggins had dodged the military draft back in 1917 and 1918. When asked why he had refused to report to the local draft board to fulfill his duties to his country, Scoggins cussedly responded: "That is for me to know and you to find out." The prosecuting attorney—probably smiling — then moved on, confident that this exchange about draft resistance had helped him paint the defendant as dangerous and subversive. ${ }^{73}$ Due to such stigmatization, the more vocal and public criticisms of the injustices and inequalities of the new economic and social order, as well as more collective forms of radical political action, had become quieter by the war's end. The history of World War I draft resistance in the Ozarks was soon buried and forgotten. Unlike the romantic tall tales of mountain moonshiners, future generations omitted stories of rural draft resistance during the First World War from the dominant narratives of Ozarks legend and lore.

Nevertheless, populist sensibilities and determined resistance persisted in the Ozarks backcountry as small farmers continued their struggles against a national—and international— political economy that seemed to constantly work against them. J.W. Scoggins, in fact, was on trial, along with several other hill farmers from his Ozarks community, to determine his role in one of the rural South's most violent cases of resistance against a government farm policy that burdened small yeomen for the benefit of the well-to-do.

\footnotetext{
${ }^{73}$ State v. Paul Curtis, et al., Preliminary Justice of the Peace Hearing, March 24-25, 1922, Independence County Courthouse, Batesville, AR (transcription of original by Susan Mosier in possession of author), 40.
} 


\section{Chapter Five}

\section{The Damn-Guvment's Tick Trouble}

On a cool Monday morning, March 20, 1922, Charles Jeffrey set out from his farm house near Jamestown, Arkansas, to begin his week's duties as a federal cattle tick inspector in mountainous western Independence County. The prosperous owner of two farms and a local blacksmith shop, Jeffrey had been hired to inspect the area's quarantined cattle and enforce local compliance with the U.S. Department of Agriculture's (USDA) tick eradication program designed to eliminate Texas fever or babesiosis. ${ }^{1}$ En route to supervise the cattle dipping at a nearby vat under his charge, Jeffrey met local farmer and fellow inspector Lee Harper on Hutchinson Mountain around 7:30 a.m. Harper, who was also supposed to dip cattle that morning, expressed concern to Jeffrey about new rumors of anti-dipping threats that were circulating in the community, which he had just heard while quail hunting with some friends. Intent on carrying out his duties, despite threatening letters that he himself had recently received, Jeffrey invited Harper to accompany him to the dipping to make sure the situation was safe, and the two proceeded toward the vat, located on a farm about a mile to the south.

\footnotetext{
${ }^{1}$ Information on Charles Jeffrey from Independence County Personal Assessment and Tax Book, 1921, County Records, Independence County Courthouse, Batesville, AR; Manuscript Census Returns, Fourteenth Census of the United States, 1920, Population Schedules, Greenbrier Township, Independence County, AR; and Janice Bufford Eddleman, "Who Killed Grandpa Charley? The Independence County Tick War and the Murder of Charles Jeffrey," unpublished paper, n.d. (in author's possession), 2. Though spelling varies from source to source, the family spells the name "Jeffrey." For a scientific explanation of ticks and Texas fever and the impact upon cattle, see Tamara Miner Haygood, "Cows, Ticks, and Disease: A Medical Interpretation of the Southern Cattle Industry," Journal of Southern History 52 (November 1986), 551-564; and Claire Strom, Making Catfish Bait Out of Government Boys: The Fight Against Cattle Ticks and the Transformation of the Yeoman South (Athens: University of Georgia Press, 2009), 7-19.
} 
Trekking along a wooded farm road, Jeffrey was suddenly cut down by a thunderous shotgun blast from a thick clump of brush nearby. Harper, who was slightly wounded in the right arm, begged the concealed assassin to spare him and scurried to a house nearby to report the incident, while Jeffrey lay gasping for his last breaths, his lungs filled with buckshot. Within an hour Jeffrey was dead, and not long afterward the county sheriff and a local posse led by Jeffrey's oldest son, Sherman, and brother, A.L., arrived at the murder scene bent on hunting down the assailant. By the next day, local, state, and federal law officials, with the assistance of bloodhounds, had apprehended six suspects and continued to hunt for more, believing that tick eradication opponents in the community had organized a "conspiracy" to murder Jeffrey. ${ }^{2}$

The Jeffrey murder was a particularly horrific instance of a broader challenge to the federal government's tick eradication program. In her recent history of the federal tick program in the South, Making Catfish Bait Out of Government Boys: The Fight against Cattle Ticks and the Transformation of the Yeoman South, historian Claire Strom seeks to explain the widespread resistance to federal tick eradication from small-scale farmers, especially those in relatively isolated places such as the highlands, marshes, and piney woods—-what she calls "the few remaining outlying bastions of southern yeomen.”3 Southern farmers opposed this government program, according to Strom, because it infringed upon their Jeffersonian political ideals and traditions of local democracy and placed great burdens upon these semisubsistence farmers who,

\footnotetext{
2 "Inspector is Victim of Assassin," Arkansas Democrat (Little Rock), March 21, 1922; "Tick Inspector is Shot from Ambush," Arkansas Gazette (Little Rock), March 21, 1922; "Tick Eradication Agent is Killed Near Batesville Today," Newport Weekly Independent, March 24, 1922; "Conspiracy Formed at Secret Meeting to Murder Jeffrey," Arkansas Democrat, March 22, 1922; "Alleged Slayers' Trial Saturday," Arkansas Gazette, March 22, 1922; Eddleman, "Who Killed Grandpa Charley?," 2, 4; Preliminary Justice of the Peace Hearing, March 24-25, 1922, Transcription of Original by Susan Mosier (in possession of author), 4-6, hereinafter cited as Preliminary Hearing. Mosier states that she "miraculously" discovered the transcript of this hearing "among some loose papers in the basement of the Independence County Courthouse," although I was unable to locate the original.

${ }^{3}$ Strom, Making Catfish Bait, 5.
} 
she claims, "rais[ed] cattle largely for themselves" or for local trade only and had no stake or involvement in national markets. Likewise, local historians have suggested that fiercely independent and authority-defying farmers in the Ozarks "saw the [tick eradication] law as too much government interference in their lives." ${ }^{4}$

An examination of the Ozarks yeomanry and the murder of Inspector Charles Jeffrey, however, warrants a more nuanced treatment. ${ }^{5}$ Rather than a high-statist program imposed from bureaucrats in Washington, local and regional elites, in fact, instigated and administered a remarkably decentralized tick eradication campaign in the name of "efficient" and "improved" agriculture. Small, less-capitalized cattle farmers who received few or no benefits from the program, meanwhile, resented the burdens and expense it placed upon them and viewed it as yet another unfair scheme cooked up by the selfish well-to-do who exerted their will with their privileged access to government power. Hardly expressions of defiance against government authority per se, many of the fiercest backcountry opponents of federal tick eradication were agrarian populist-progressives and socialists. This story of rural resistance against government power, more accurately, was another story of the rural dispossessed's populist defiance against "well-bred" locals, their competing New South interests and visions, and their favored status in American and regional politics.

These Ozarks yeomen, furthermore, were in no way isolated from national, and even international, market forces. Despite relative geographic isolation in the Ozarks, small farmers participated in national agricultural markets as they struggled to adapt to an industrializing and

\footnotetext{
${ }^{4}$ Strom, Making Catfish Bait, 3, 4, 106. For an abridged overview of Strom's work, see Claire Strom, "Texas Fever and the Dispossession of the Southern Yeoman Farmer," Journal of Southern History 66 (February 2000), 49-74.

${ }^{5}$ Throughout this chapter, the term "yeoman" is used loosely and interchangeably with such terms as "small farmer" and "smallholder." 2
} 
agribusiness-oriented political economy, and these market trends impacted their lives in significant ways. The mast and greenery available in the forests and rugged terrain of the open range in the Ozarks were well-suited for raising cattle, and many hill farmers utilized these resources in their efforts to stay afloat and get ahead amid difficult economic prospects in the region. ${ }^{6}$

In the Ozarks, while some yeomen certainly raised only one or two cows for strictly subsistence purposes (mostly milk and butter), cattle represented the most valuable cash commodity for many others, even if their herds were much smaller and comprised poorer stock than those of more prosperous cattlemen. Many small farmers in the Ozarks, who had long yearned for better days, sought to benefit from the high cattle prices driven by increased international demand during the World War I years; they likewise suffered from the beef-market fallout during the postwar years that sent cattle prices spiraling to their lowest points in over a decade. Their attempts to sustain their farms by adapting more readily to national and international economic forces elevated their insecurity and made them more dependent on the same capitalist-controlled, elite-run political economy that had been working to deteriorate smallholder farm life since the late 1800s. Backcountry Ozarkers' connection to volatile national market forces, rather than their isolation from commercial farming activities, brought their opposition to burdensome dipping laws to a boil in the postwar years. Although there had been discontent over and resistance to the demands of the federal tick eradication program in many parts of the South since its inception in 1906, the most violent and deadly incidents of resistance

\footnotetext{
${ }^{6}$ Along the same lines, Robert S. Weise, Grasping at Independence: Debt, Male Authority, and Mineral Rights in Appalachian Kentucky, 1850-1915 (Knoxville: University of Tennessee Press, 2001), argues that rural mountaineers tried to adapt their family-farm economies to timber and mining industries in their efforts to maintain their traditional society and culture.
} 
occurred amid the post-World War I agricultural crisis and the ensuing rural economic desperation of the early 1920 s. $^{7}$

The eradication program had its origins in a congressional appropriation to the USDA, chiefly orchestrated by southern congressmen, in 1906 to combat Texas fever and the cattle tick in the southern states. A quarantine that roughly followed the northern border of the old Confederacy but also included southern California had been established in 1891 by the USDA to protect northern cattle from Texas fever, caused by a protozoa hosted by ticks. This deadly and contagious disease carried by southern cattle bound for slaughter and meat-packing houses in the North and Midwest threatened the herds of northern and midwestern cattlemen, whose highergrade breeds were vulnerable to the fever. While native "scrub" cattle in the South had developed immunity to the fever, the quarantine line posed a disadvantage for the increasing number of wealthier cattlemen in the South who were attempting to emulate "progressive," midwestern-style cattle raising and wanted to participate in the more profitable higher-grade beef markets. Although there was an "open season" in the winter during which southern cattle could be shipped above the quarantine line without restrictions, the quarantine hindered southern cattlemen's access to ship their stock to northern and midwestern markets. Southern cattle had to be either slaughtered in the South and then shipped out (which proved problematic since there were few meat-packing houses in the South) or shipped in special "quarantine" railroad cars and slaughtered immediately when they reached their northern or midwestern destinations. Either way, the extra expense and hassle cut significantly into profits, particularly for those cattlemen

\footnotetext{
${ }^{7}$ Another murder, explored in some detail by Strom, occurred in the piney woods of Echols County, Georgia, in February of 1923, Strom, Making Catfish Bait, 1, 67, 72-74, 95, 178. Also see Claire Strom, "Editorials and Explosions: Insights into Grassroots Opposition to Tick Eradication in Georgia, 1915-1920," Georgia Historical Quarterly 88 (Summer 2004), 197-214.
} 
investing in higher-quality livestock to sell to northern slaughter houses to be fattened and sold on choice-grade beef markets. ${ }^{8}$

But Texas fever also posed a more immediate threat to these cattlemen attempting to raise top-quality, pure-bred stock. Just as the disease was proving deadly to cattle in the North and Midwest, the fever tick was taking its toll on high-grade purebreds imported by more prosperous cattlemen. These well-to-do farmers, their political representatives, and the scientific experts promoting their interests at southern agricultural experiment stations and the USDA were the key figures in the establishment of the tick eradication program in $1906 .^{9}$

Assuming that the eradication program would receive nearly unanimous support as a "progressive" measure, the USDA initially embarked upon a voluntary program. Placing tick eradication under the charge of its Bureau of Animal Industry (BAI), the USDA sought to work closely with state agricultural experiment stations and with county governments, offering matching funds for voluntary local programs and leaving the planning and administration mostly to local officials. The program's supporters and the BAI soon found, however, that farmers in only a few locales were willing to join their effort, and those tended to be in more prosperous agricultural areas — not surprisingly those that stood to gain the most from tick eradication. ${ }^{10}$

In Arkansas, eradication began in the northern part of the state, with special interest given to the relatively prosperous counties of the Springfield Plain subregion of the Ozarks. Washington and Benton counties, the former the home of the state's flagship university, had long

\footnotetext{
${ }^{8}$ Strom, Making Catfish Bait, 2; R.R. Dinwiddie and W. Lenton, "Notes on the Cattle Tick and Tick Fever of Cattle," Bulletin No. 101 (Fayetteville: Arkansas Agricultural Experiment Station, 1908), 212-214.

${ }^{9}$ Strom, Making Catfish Bait, 2, 5, 24; Dinwiddie and Lenton, "Notes on the Cattle Tick", 214.

${ }^{10}$ Strom, Making Catfish Bait, 2-3, 39, 48.
} 
set themselves apart from the rest of the rugged Ozarks as a "progressive" agricultural center. These counties were at the forefront of the state's effort to establish an improved cattle industry. Generally better-off farmers there heeded the suggestions of agricultural scientists and experts at the nearby Arkansas Agricultural Experiment Station at the University of Arkansas who claimed that "in no other State is there greater need of improvement of the native cattle or greater prospective profits from the importation of pure bred males of the beef breeds..." ${ }^{11}$ While opposition to tick eradication in Washington and Benton counties was not entirely absent, the program "was more favorable among the prosperous farmers of the Springfield Plain," as historian Brooks Blevins puts it, "which was the birthplace of such progressive intervention." 12 Progressive Washington and Benton county farmers and their prominent cattle growers' associations answered the call: "The better class of intelligent and up-to-date farmers and stock owners was willing and eager to do all in their power, both by precept and example, to forward the important work of tick eradication," commended the director of the Agricultural Experiment Station in 1907. By 1914, Washington and Benton counties, along with several others, had been declared tick free and were placed above the federal quarantine line. ${ }^{13}$

Eradication was less successful in other parts of the region and state. Whereas more prosperous cattlemen in the business of raising purebred cattle for choice beef markets embraced and encouraged the eradication program, smaller farmers raising "scrub" stock on the open range were less inclined to see any benefits from the program. Even in counties that had been declared

\footnotetext{
${ }^{11}$ Dinwiddie and Lenton, "Notes on the Cattle Tick", 199.

${ }^{12}$ Brooks Blevins, Hill Folks: A History of Arkansas Ozarkers and Their Image (Chapel Hill: University of North Carolina Press, 2002), 96.

${ }^{13}$ W.G. Vincenheller, "Cattle Tick Eradication in Northwest Arkansas," Bulletin No. 93 (Fayetteville: Arkansas Agricultural Experiment Station, 1907); Holly Hope, Dip That Tick: Texas Tick Fever Eradication in Arkansas, 1907-1943 (Little Rock: Arkansas Historic Preservation Program, 2005), 10.
} 
tick free by 1914, eradication efforts had had to overcome the grumbles and groans of opponents. In rugged Newton County, for instance, tick inspectors faced "some trouble here at first, as many refused to dip cattle," but the program prevailed, nonetheless. Once regional and local eradication supporters and the BAI realized that many small farmers were not willing to cooperate with the program voluntarily, they abandoned their "carrot" approach for the "stick," working through the apparatuses of state and local governments to force mandatory dipping by law. $^{14}$

The conflict over tick eradication was part of a broader conflict between those groups historians have generally described as "progressives" and "traditionalists." 15 These labels, however, run the risk of oversimplification and of misunderstanding the real dynamics of the conflict. As the recent works of historians such as Charles Postel and Elizabeth Sanders have shown, small farmers - the so-called "traditionalists"—-stood among the most determined "progressive" champions of government-supported educational advancements and scientific farming improvements during the late nineteenth and early twentieth centuries. ${ }^{16}$ In Arkansas, for instance, significant levels of resentment developed over the University of Arkansas's and the state Agricultural Experiment Station's relatively inaccessible location in Fayetteville in the extreme northwestern corner of the state. As Blevins has noted, the presence of the state university and experiment station in Fayetteville "provided farmers of northwestern Arkansas with valuable scientific information and helped spur the development of a prosperous and

\footnotetext{
${ }^{14}$ Blevins, Hill Folks, 95; Quotation from Hope, Dip That Tick, 10; Strom, Making Catfish Bait, 2-3.

${ }^{15}$ The historical literature adhering to this "traditionalists" v. "progressives" paradigm is extensive. To name just a few examples, see William A. Link, The Paradox of Southern Progressivism, 1880-1930 (Chapel Hill: University of North Carolina Press, 1992); Jeanette Keith, Country People in the New South: Tennessee's Upper Cumberland (Chapel Hill: University of North Carolina Press, 1995); and Strom, Making Catfish Bait.

${ }^{16}$ Charles Postel, The Populist Vision (New York: Oxford University Press, 2007); Elizabeth Sanders, Roots of Reform: Farmers, Workers, and the American State, 1877-1917 (Chicago: University of Chicago Press, 1999).
} 
diverse agricultural community; conversely, the station's isolation and subsequent narrow subregional focus denied farmers elsewhere in the Ozarks and much of the state the benefits of research results and information until the establishment of the [federal] extension service on the eve of World War I."17 Though his own political agenda aimed more at fiscal conservatism than a "progressive" expansion of state services, Governor George W. Hays attempted to tap populist animosities in Arkansas about the uneven benefits of the state's university. In a public address in August 1916, "George the Wobbler," as the infuriated Fayetteville Democrat called him, "attack[ed]" the university as "a complete failure located where it is, principally because of its geographical situation." Though the governor declared that he was "in favor of removing the state university to some central location in the state," he never took any serious action. His rhetoric and its populist appeal, nevertheless, are revealing. Rural folks demanded more equitable benefits from their government institutions. ${ }^{18}$

Small farmers in the Ozarks objected not so much about government's expanded role in farm economics and education but more to how better-off agricultural interests- - those with the "clout" - pulled the strings and shaped the designs of government programs for their own ends. The Smith-Lever Act of 1914, which was engineered and pushed hardest by congressmen representing predominantly rural districts in the South and West, created the Extension Service in the USDA and provided matching federal funds for farm agents in counties that agreed to cover one-third of the administrative costs (states were also expected to contribute one-third of the expense). Many small farmers, however, resented the regressive taxes imposed by state and

\footnotetext{
${ }^{17}$ Blevins, Hill Folks, 43.

18 "George the Wobbler Intimates That He May Run for Senate; Attacks University," Fayetteville Democrat, August 10, 1916.
} 
county governments to raise the local matching funds that were required, especially when they became convinced that the local "big shots" would control the programs and benefit the most anyway. In July 1918, for instance, small farmers in Boone County circulated petitions to demand that the USDA fire their county's agricultural agent, S.D. Carpenter. Though Carpenter denied their accusations, backcountry populists claimed "that he took an active part in the recent movement of the thresher owners of Boone County to charge an exorbitant price."19 Instead of helping improve the viability of their farms, these rural folks must have believed that this government program was helping those who needed it the least and, in doing so, only made their situation worse. Similarly, to many poor and middling hill farmers, the USDA's tick eradication program seemed unnecessary and unfair.

While most dipping opponents merely grumbled or simply refused to dip their cattle in defiance of the local and state mandates until they were slapped with fines or had their cattle confiscated, others expressed their anger with this "taste of government intervention" more forcefully. Some angry farmers in Izard County destroyed dipping vats with dynamite at Guion and Lunenburg in 1912. Although no one was ever charged, the tick inspector at Lunenburg reported to local law officials that he had been chased by about twenty-five night riders and barely escaped their wrath by hiding out in a remote hollow. Such intimidation of inspectors and destruction of dipping vats was repeated on numerous occasions throughout the South. The dynamiting of vats became, in the words of Claire Strom, "the most common form of [violent] resistance." She explains that cheap and readily available dynamite gave dipping opponents the

19 “Seek Agent's Removal," Arkansas Gazette, July 20, 1918. 
publicity and attention they desired, as local and state newspapers eagerly covered these dramatic episodes. $^{20}$

Eradication officials and supporters were appalled at such resistance. Only

backwardness, ignorance, and selfishness could explain such obstinate behavior in their eyes. Officials simply could not understand why anyone would oppose such a progressive measure. Although it is unclear how he derived his statistics, Arkansas's state veterinarian W. Lenton claimed that cattle ticks were costing the South "forty millions of dollars annually," which was inexcusable given that ticks "can be entirely eliminated with little expense and a little trouble on the part of cattle owners..." For Lenton, ignorance and indifference toward the common good were the obstacles. "If every farmer understood this question and was willing to spend a few cents and a few minutes' time each week," he wrote in his attempt to strike a populist chord of public duty, "between now and the first of next November, every tick in Arkansas could be killed."21

But for yeoman farmers, tick eradication was more trouble than a "few cents and a few minutes' time each week," and they remained unconvinced that it truly benefitted the "common good." As Strom explains, tick eradication worked for the interests of prosperous cattlemen and mostly against the interests of yeomen. ${ }^{22}$ Prosperous cattlemen emulating midwestern stock raising, who reaped the benefits of tick eradication and were equipped with corrals and pens,

\footnotetext{
${ }^{20}$ Blevins, Hill Folks, 95; Brooks Blevins, Cattle in the Cotton Fields: A History of Cattle Raising in Alabama (Tuscaloosa: University of Alabama Press, 1998), 63; Strom, Making Catfish Bait, 67-68.

${ }^{21}$ Dinwiddie and Lenton, "Notes on the Cattle Tick and Tick Fever of Cattle," 211. Blevins writes that yeoman dipping opponents in Alabama were at times referred to as "seconds" by eradication supporters, reflecting "their lower-class status in the community," Blevins, Cattle in the Cotton Fields, 62.

${ }^{22}$ Throughout this chapter, I refer to "prosperous," "well-to-do," and "wealthier" cattlemen as those farmers who were emulating midwestern cattle-raising methods, specifically those with purebred herds and fenced pastures. Their interests typically opposed those of yeomen who were raising "scrub" or native cattle on the open range.
} 
neat fences and pastures to contain their herds, and the money and labor to invest in tick eradication methods, were in much better shape to treat their animals for tick eradication. Yeomen, on the other hand, had to round up their semi-wild cattle that roamed free on the open range and drive them to dipping vats through forests and difficult terrain, a "nearly impossible" task. Eradication laws required farmers to dip all of their cattle on a bi-weekly basis until officials declared that district tick free. For small farmers who usually relied upon family and occasionally neighbors for labor, this almost always consumed valuable time and resources and distracted them from other important farming ventures that were necessary to make ends meet. Furthermore, the flat tax of five cents per head on cattle that was levied to help finance the eradication program in Arkansas also proved a bigger thorn in the side of poorer yeomen than more well-to-do cattlemen who believed the tax was more than worth its expense. ${ }^{23}$

Even more significant, perhaps, than the greater inconvenience and cost of tick eradication for small farmers was the fact that the program stood to benefit yeomen little, if at all. This fact was not, however, due to yeomen's isolation from and disinterest in the national and international cattle market. Rather, a closer look at the differentiation within the national beef market reveals that well-to-do cattlemen and yeomen targeted different sectors of that market. While wealthier cattlemen who possessed the capital to invest in higher-quality breeds, fenced grazing pasture, and nutritious feeds aimed at the choice-grade, top end of the beef market, yeomen's native "scrub" breeds were generally bound for the low-end, canned beef market. $^{24}$

${ }^{23}$ Strom, Making Catfish Bait, 39-40, 56, 62, quote on 56; Hope, Dip That Tick, 13.

${ }^{24}$ On the differentiation within the beef market, see Dinwiddie and Lenton, "Notes on the Cattle Tick," 213-214. 
For small farmers lacking the necessary land and capital to invest in raising high-quality breeds for choice-grade beef, raising lower-quality breeds for the low end of the market was most feasible and profitable, since raising these "scrub" cattle on the open range required minimal investment. Aside from yeomen occasionally penning calves up for some last-minute fattening before sending them to market, these cattle subsisted on the grasses and mast of the open range at little or no cost. Yeomen usually sold their cattle to drovers or drove their small herds themselves to the nearest railroad town to be loaded onto cattle cars and shipped to market. ${ }^{25}$ Farmers in the Ozarks frequently shipped their cattle to Missouri. John Quincy Wolf remembered his uncle selling open-range cattle raised in the Izard County hills along the White River during the latter half of the nineteenth century. "Very early Uncle saw the profit in raising cattle, for they ran on the free ranges all the year, finding abundant forage in the winter on the south sides of the hills, up the coves, and along the creeks and the river valleys where cane was abundant," recalled Wolf. "In the spring Uncle sold from ten to twenty-five head of cattle to Missouri buyers and in the fall two or three bales of cotton, which brought in more than enough money for the family needs." ${ }^{26}$ Ozarks yeomen continued to see the economic benefits of openrange grazing well into the twentieth century. The Yellville Mountain Echo reported in early June of 1921 that local farmer George Roberson "shipped a car load of fat cattle to butchers at Springfield, Mo., the first of the week." "These cattle," the newspaper noted, "had grown fat on the open range...Here in the Ozarks where our range is fine, and where cattle have free access to all the pure running water they take on flesh very fast, and make the very best of beef." ${ }^{27}$ In

\footnotetext{
${ }^{25}$ On cattle drovers in the Alabama uplands, see Blevins, Cattle in the Cotton Fields, 46.

${ }^{26}$ John Quincy Wolf, Life in the Leatherwoods, ed. Gene Hyde and Brooks Blevins, (Fayetteville: University of Arkansas Press, 2000), 33.

${ }^{27}$ Mountain Echo (Yellville), June 2, 1921.
} 
addition to requiring little land, raising cattle on the open range demanded minimal attention and labor, allowing farmers to devote their time and energy to other endeavors. Thus, even with "canner" beef bringing less than half the price of top-grade beef, small farmers enjoyed significant profits from the lower-quality cattle raising that best suited the resources at their disposal.

Although well-to-do cattlemen and agricultural experts insisted that ticks were costing southern cattlemen millions of dollars each year, yeomen rarely saw any benefits from dipping their cattle. State Veterinarian W. Lenton claimed in 1908 that even low-grade canners were losing about twenty-five to fifty cents per hundred pounds under the quarantine. But while the quarantine may have shaved a few dollars off the price that yeomen might have otherwise received, the costs of eradication outweighed its benefits in their eyes. After all, ticks were not killing their cattle or making them ill, and the costs and inconvenience of dipping were great enough for them that earning a few dollars less could be overlooked. ${ }^{28}$

Perhaps, if it were not for agricultural experts telling them so with statistical analysis, yeomen would hardly ever have noticed any real negative impacts on cattle prices caused by the tick quarantine, as such subtle nuances were hardly distinguishable from typical market fluctuations. As cattle prices in Arkansas more than doubled between 1912 and 1918, it is likely that many yeomen who were being forced to dip their cattle dismissed eradication officials' and supporters' claims that ticks were hurting their economic well-being; their tick-infested cattle

\footnotetext{
${ }^{28}$ Dinwiddie and Lenton, "Notes on the Cattle Tick," 214.
} 
were bringing higher prices than ever. ${ }^{29}$ Furthermore, evidence suggests that successful eradication and lifting the quarantine did not necessarily mean the improved cattle prices that officials promised. According to USDA statistics, although South Carolina had been completely freed from the quarantine by 1921 , average cattle prices in that state fell from $\$ 20.30$ per head in 1921 to $\$ 13.80$ in 1922 . Similarly, although a few of its counties were requarantined later, Mississippi's average cattle prices fell from $\$ 14.10$ per head in 1921 to $\$ 10.80$ in 1922 , after that state had been released from the quarantine. ${ }^{30}$ Yeomen, then, must have had a hard time buying into agricultural officials' claims that tick eradication was necessary and urgent for the economic betterment of all southern cattle farmers.

Exaggerated claims made by frustrated agricultural officials in their attempts to "educate" southern farmers probably led yeomen to question the validity of the tick eradication program as well. State Commissioner of Agriculture Clay Sloan went so far in his efforts to stress the dangers of cattle ticks as to claim that "one tick can draw 200 pounds of blood from one animal in a season." The editor of the Batesville Guard, Independence County's leading newspaper, who supported the "progressive" tick eradication program, was utterly disgusted at such a potentially damaging statement by an "expert statistician." "Why, the dreaded blood-sucking vampires of India, or the gorgeously and most stupendously advertised blood-sweating 'behemoth' of olden circus fame, would have no odds on one of the hideous [tick] monsters with a capacity of a pound of blood a day," retorted the editor. "Frankly we do not believe in such far drawn and imaginative arguments," he asserted, "and it is just such 'freak' statements which

\footnotetext{
${ }^{29}$ U.S. Department of Agriculture, "Prices Received by Farmers for Beef Cattle: United States and States Monthly and Annual Average, 1909-59," Statistical Bulletin No. 265 (Washington, D.C.: USDA Agricultural Marketing Service, 1960), 38.

${ }^{30}$ U.S. Department of Agriculture, United States Department of Agriculture Yearbook, 1921 (Washington, D.C.: Government Printing Office, 1922), 44, 691.
} 
have caused so much ridicule and opposition to an otherwise intelligent campaign of education." ${ }^{31}$

In addition, yeomen's suspicion and opposition to the program surely rose as it became obvious that tick eradication was inherently designed to benefit more prosperous cattlemen and an "improved"-breed cattle industry. This became more than clear when tick eradication officials and supporters began urging the closing of the open range to accelerate and ensure the success of the tick program. The director of the Arkansas Experiment Station pointed to the open range as "the main factor in propagating and distributing the tick," arguing that "were a general herd law in force, the [tick] question would become, if not a simple one, at any rate a much less difficult one than it is at present. ${ }^{, 32}$ Eradication officials' advocating to close the open range must have struck a sensitive nerve with yeomen farmers who depended upon the free range for an important source of cash income; closing the range would likely mean running them out of the cattle business altogether. ${ }^{33}$

Feeling wrongly disadvantaged by the tick eradication program, a number of disgruntled yeomen took their grievances to the courts in hopes of redress. While judges and county officials were sometimes inclined to side with dipping opponents, such as in Van Buren County where the county judge refused to enforce mandatory dipping until a majority of citizens demonstrated that they supported the program, yeomen typically did not fare so well in the court room. This proved especially true as tick eradication cases reached the state's supreme court. In

\footnotetext{
${ }^{31}$ Newark Journal, September 22, 1911; Batesville Guard, March 29, 1912, quoted in Susan Mosier, "The 1922 'Tick War': Dynamite, Barn Burning, and Murder in Independence County," Independence County Chronicle 41 (October-January 1999-2000), 4-5.

${ }^{32}$ Vincenheller, "Cattle Tick Eradication in Northwest Arkansas," 23-24.

${ }^{33}$ On the stock law and yeoman opposition, see Hahn, The Roots of Southern Populism, 58-63, 239-268.
} 
Davis v. State in 1916, the Arkansas Supreme Court upheld the constitutionality of the state legislature's Act 86 of 1915, which authorized the enforcement of mandatory dipping and prescribed penalties for non-compliance. And in Cazort v. State in 1917, the court upheld the constitutionality of penalizing violators of cattle quarantine orders. ${ }^{34}$ With these rulings, lawabiding yeomen had no choice but to dip their cattle.

Most small cattle farmers grudgingly took their cattle to the dipping vats every other week, grumbling to themselves and their neighbors about what they perceived to be a ridiculous and unfair law. Other less scrupulous farmers continued to refuse to dip their cattle and risked being fined or having their cattle taken from them when they were finally caught defying the law by inspectors. But during the World War I years, tick eradication was a little easier pill to swallow for most farmers. They still resented the difficulties of rounding up their cattle and paying the dipping tax with no apparent benefit to them, but the record cattle prices they were receiving during those years undoubtedly helped offset the hassle and expense of dipping.

Although southern newspapers naturally devoted most of their attention to the great surge in cotton prices during the war years, the increased international demand for nearly all American farm products during the war drove other prices, including beef, to unprecedented levels. The war and food shortage in Europe also coincided with a devastating drought in Texas, which hurt that important beef-producing state but boosted demand even higher for others. ${ }^{35}$ Whereas the annual average of prices received by Arkansas cattle farmers fluctuated back and forth around

\footnotetext{
${ }^{34}$ Strom, Making Catfish Bait, 93; Davis v. State, 126 Ark. 260, Supreme Court of Arkansas, November 13, 1916; Cazort v. State, 130 Ark. 453, Supreme Court of Arkansas, October 1, 1917.

${ }^{35}$ On the dramatic rise in agricultural prices during World War I, see Gilbert C. Fite, Cotton Fields No More: Southern Agriculture, 1865-1980 (Lexington: University Press of Kentucky, 1984), 94-96; and James H. Shideler, Farm Crisis, 1919-1923 (Berkeley: University of California Press, 1957), 10-19. On the drought in Texas, see Strom, Making Catfish Bait, 129.
} 
$\$ 3.50$ per 100 pounds between 1909 and 1912, prices rose to about a three-year average of $\$ 4.50$ between 1913 and 1915, climbed to $\$ 4.90$ in 1916 , and then shot up to $\$ 6.40$ in 1917 , peaking at an annual average of $\$ 7.00$ in 1918. In May of 1918, average cattle prices in Arkansas hit a whopping $\$ 8.00$ per 100 pounds, a level that would not be matched again until $1942 .{ }^{36}$

Such an increase in the value of cattle did not go unnoticed. In an editorial on November 8, 1916, titled "Meat Prices are High," the Batesville Guard sought to draw its Independence County readers' attention to the tremendous rise in livestock prices and encourage farmers to diversify. Citing an agricultural official in Texas, the editorial commented that "meat animals are more likely to be higher next year than cotton is likely to remain high." Warning readers not to become too comfortable with good cotton prices, the Texas official explained that "in one year cotton has risen from 10 to 18 cents; it can fall in another year back to 10." Referencing the increased demand in war-torn Europe, he assured readers that the cattle market promised to be a much safer and stable market than cotton, since "people can economize in the use of cotton goods...[but] cannot economize much in the matter of food." ${ }^{\prime 37}$

Analysis of personal property records of Independence County farmers involved in the Charles Jeffrey murder affair suggests that yeomen responded to these market incentives. Although most yeomen lacked the capital to greatly expand the size of their herds, some betteroff yeomen did seize the opportunity in hopes of improving their families' economic lot. But even many of those who lacked the capital to greatly expand their small cattle operations enlarged their herds when possible by buying a few cows from neighbors when they had extra

\footnotetext{
${ }^{36}$ USDA, "Prices Received by Farmers for Beef Cattle," 38.

${ }^{37}$ Batesville Guard, November 8, 1916.
} 
cash or keeping some of the heifers (female calves) from natural reproduction to add to the next year's stock of breeding cows. Furthermore, even for those who did not significantly expand their herds, the high prices received by selling each season's naturally-produced calves put more money in their pockets than most had ever imagined.

But while yeomen enjoyed the record prices of the war years, they also suffered the consequences of the agricultural crisis that ensued when high demand for American farm products wore off after the war's end. In fact, as historian James H. Shideler has pointed out, weakening livestock markets were the first indicators of the general post-war farm crisis to come, claiming that the "declining European market for meat coupled with continued high-level American production brought about a crisis in livestock, which was a forecast of what was later to come to the rest of agriculture. ${ }^{38}$ In Arkansas, the prices that cattle farmers received per 100 pounds fell from the $\$ 8.00$ peak in May of 1918 to $\$ 5.80$ by the end of 1919 . By the end of 1920 , prices had fallen to $\$ 4.40$ per 100 pounds, plummeting to $\$ 3.20$ by December of $1921 .^{39}$

In the words of historian Gilbert C. Fite, "farmers were not only discouraged over low prices, they were downright angry." Historians have given most of their attention to discontented farmers in what are usually considered "commercial" agricultural areas during the post-World War I farm crisis, such as the retaliation and destruction caused by angry "night riders" in cotton and tobacco regions. ${ }^{40}$ But it is important to situate the escalation of small farmers' violent resistance to federal tick eradication within the context of post-war agricultural panic, rather than merely seeing it as merely a stagnant continuation of the yeomanry's

\footnotetext{
${ }^{38}$ Shideler, Farm Crisis, 37.

${ }^{39}$ USDA, "Prices Received by Farmers for Beef Cattle," 38.

${ }^{40}$ Fite, Cotton Fields No More, 102-103.
} 
Jeffersonian ideology and resentment toward the government program's encroachment upon local rights. ${ }^{41}$ While yeoman cattle farmers in the Ozarks may have been able to endure complying with tick eradication amid the high cattle prices of the war years, the postwar beef market fallout restored the now sharper-than-ever pains of forced cattle dipping — pains that some yeomen were evidently no longer willing to tolerate.

The dynamiting of dipping vats picked up significantly not long after cattle prices began to dip, becoming a fairly regular occurrence in the hills of Independence County by 1922 . The first vat in the county was blown up near Hutchinson Mountain in 1919, and four others were destroyed in the area before Jeffrey was murdered in March of 1922. Another vat was dynamited near Locust Grove in 1921, and a deputy sheriff went to that community to force twenty-two farmers to dip their cattle after the incident occurred. To compound the problem of falling cattle prices, eradication officials stiffened regulations. It appears that officials and the program's supporters realized that their efforts to correlate the necessity of tick eradication with the promise of higher prices were being undermined during the war years, as "ticky" cattle were bringing over double what they had when the program first started. State legal revisions went into effect in March of 1919 in Arkansas that outright prohibited farmers from selling any cattle within a quarantine district that had not been declared tick-free and issued a signed certificate by

\footnotetext{
${ }^{41}$ Strom relegates the severity of the post-war agricultural crisis and its part in the escalation of violence toward tick eradication to one passing sentence, in which she states that "The most deadly episodes of the tick wars took place in the early 1920s, a time when the postwar crisis of 1919, the aftermath of the war itself, and the burgeoning rural depression augmented everyone's fear and desperation." She instead emphasizes that "in a nation as violent as the United States, the federal determination to implement eradication combined with yeoman intransigence almost inevitably led to escalation," Strom, Making Catfish Bait, 178.
} 
a federal inspector. ${ }^{42}$ Thus, no longer could farmers sell cattle simply marked "quarantine," since they now had to possess an inspector's certificate to sell them at all.

With farmers' ability to sell cattle greatly impeded and with prices plunging to $\$ 3.10$ per 100 pounds in January of 1922 - the lowest they had been at any point since 1911 -panic spawned a surge in violence against tick eradication. ${ }^{43}$ As blowing up and burning dipping property became evermore widespread, disgruntled dipping opponents' retaliation also became more personal. Threats and intimidation against tick inspectors were nailed to trees and fences at dipping vats throughout the hills of Independence County. Hoping to break the spirit and resolution of eradication officials, threats against law-abiding farmers who sought to comply with mandatory dipping were also reported. ${ }^{44}$

It was in this atmosphere of boiling tempers that an unknown assassin gunned down Inspector Jeffrey on Hutchinson Mountain on March 20, 1922, resulting in the eventual arrest of nine suspected "conspirators." Questioning revealed that these suspects and about thirty other men had attended a "secret" meeting on the tick question at one suspect's farm after church services the Sunday afternoon prior to the murder, where officials believed the dipping opponents had plotted to kill Inspector Jeffrey. The six suspects initially arrested, who the state press reported "refused to talk," were held at the county jail for a preliminary hearing before Justice of the Peace J.A. Holmes to commence on March 24, while law officials and their bloodhounds searched for co-conspirators and reported that unknown murder accomplices had

\footnotetext{
${ }^{42}$ Mosier, "The 1922 'Tick War," 6-7; “Tick Eradication Laws," Bulletin No. 160 (Fayetteville: Arkansas Agricultural Experiment Station, 1919), 11.

${ }^{43}$ USDA, "Prices Received by Farmers for Beef Cattle," 38.

${ }^{44}$ Mosier, "The 1922 'Tick War,"” 7; Preliminary Hearing, 4, 25.
} 
been attempting "to throw the hounds off the trail by firing the woods" in the vicinity of the murder scene. ${ }^{45}$

Like the "wild rumors" of communist conspiracy that circulated during Arkansas's infamous Elaine Race Riot of 1919, Red Scare hysteria found another outlet in the press coverage of anti-dipping defiance. Just as Georgia's state veterinarian had condemned a "Bolsheviki contingent" for dynamiting dipping vats in Lowndes County, Georgia, in the summer of 1917, the Arkansas Democrat linked dipping opposition to Socialist anarchy, claiming that one of the suspects arrested for Jeffrey's murder, James McGee, was “a Socialist leader in his section of the country." ${ }^{46}$ Indeed, there is good reason to speculate that McGee may have been a Socialist. Sometime after 1910, McGee's family, along with the families of his son and brother, came to Hutchinson Mountain from Kiowa County, Oklahoma, a well-known stronghold of agrarian Socialism in the Southwest. ${ }^{47}$ The Socialist Party had been considerably active in Independence County between 1908 and 1912, furthermore, when it "ran a full slate in each election." Under the leadership of "loyal” Farmers' Union member W.P. Datherow, the local party organization sought to appeal especially to discontented farmers. Agrarian Socialists in the western South, moreover - particularly the "secret, direct-actionist" Working Class Union which, according to historian Jim Bissett, "claimed as many as thirty-five thousand Oklahoma and Arkansas farmers among its membership in 1916"- counted themselves among the most

\footnotetext{
45 "Conspiracy Formed at Secret Meeting to Murder Jeffery," Arkansas Democrat, March 22, 1922; "Two Brothers are Held for Murder," Arkansas Gazette, March 24, 1922.

${ }^{46}$ Michael B. Dougan, Arkansas Odyssey: The Saga of Arkansas from Prehistoric Times to Present (Little Rock: Rose Publishing Co., Inc., 1994), 378; Strom, Making Catfish Bait, 90; "Conspiracy Formed at Secret Meeting to Murder Jeffery."

${ }^{47}$ Manuscript Census Returns, Thirteenth Census of the United States, 1910, Population Schedules, Otter Creek Township, Kiowa County, OK; Jim Bissett, "Socialist Party," Encyclopedia of Oklahoma History and Culture, http://digital.library.okstate.edu/encyclopedia/entries/S/SO001.html.
} 
aggressive opponents of the government's cattle dipping mandate in their broader stand "against the farmer who farms the farmer." 48

An examination of 1920 election returns, however, indicates that if McGee was a Socialist organizer, he had yet to win over the votes of other farmers on Hutchinson Mountain. Of the twenty-seven votes cast by Relief Township in the presidential election, only four went to Socialist Eugene Debs, while merely one of twenty-six votes went to the Socialist gubernatorial candidate, Sam Busler, and those votes were probably cast by McGee and his family. Instead, most of the township voted Republican, but this in itself might have been an expression of political protest against the status quo. ${ }^{49}$ Granted, Independence County and other parts of the Ozarks had an unusually large Republican presence that dated back to the Civil War years, but the county, like the rest of the Solid South, was firmly Democratic by the 1920 s.

The stigma attached to dipping opposition could be seen clearly in the strategies of both the prosecution and defense in the preliminary hearing held before Justice of the Peace J.A. Holmes on March 24-25. The prosecution set out to show that angry dipping opponents on Hutchinson Mountain had called the "secret" meeting together to organize Inspector Jeffrey's assassination as an act of lawless rebellion. Defense attorney Earl C. Casey, undoubtedly aware of the incriminating image of tick eradication opposition, sought to portray the suspects not as dipping opponents but as concerned and confused citizens unsure about the technicalities of the dipping law, and their "tick meeting" not as a secret gathering of frustrated dipping opponents

\footnotetext{
${ }^{48}$ G. Gregory Kiser, “The Socialist Party in Arkansas, 1900-1912,” Arkansas Historical Quarterly 40 (summer 1981), 140; Bissett, Agrarian Socialism in America, 108, 142, 145.

${ }^{49}$ Batesville Guard, November 10, 1920.
} 
but as a gathering of law-abiding citizens discussing and informing one another on the "dipping question. ${ }^{, 50}$

The prosecution suggested that dipping opponents at the tick meeting had paid off local riffraff Paul Curtis to do the shooting. Bloodhounds had led law officials to the home of farmer and fellow suspect Aaron Strothers, where Curtis admitted he had stayed the night before the shooting. Curtis had earned himself quite a reputation as a lawless character in preceding years. In the spring and fall of 1915, Curtis pleaded guilty on charges of disturbing religious services, and he was sentenced in 1916 to a one-year prison term for stealing two mules. Even more importantly, only months before Jeffrey's murder, Curtis was indicted in a murder case but was acquitted for lack of evidence. Curtis, a sharecropper who lived with his elderly mother and had no property of his own, also testified that he had recently been looking to hire himself out as a farm laborer with no success. The prosecution argued that Curtis, whose boots matched tracks found near the murder scene, must have taken the cash from tick opponents at the Sunday tick meeting and shot Inspector Jeffrey in cold blood. It also suggested that his fellow anti-dipping conspirators had paid Curtis's attorney fees. ${ }^{51}$

Although Justice Holmes was sufficiently convinced to hold the defendants without bail for a grand jury proceeding, the prosecution got very little help from tight-lipped witnesses at the preliminary hearing. As the Arkansas Democrat reported, most of those "placed on the stand by the state made poor witnesses, plainly showing signs of fear...[and] 'lapses of memory.'” Indeed, witnesses, most of whom admitted that they had attended the tick meeting, usually kept

\footnotetext{
${ }^{50}$ Preliminary Hearing, 6ff.

51 "Conspiracy Formed at Secret Meeting to Murder Jeffery”; State v. Paul Curtis, nos. 952 and 953, Spring and Fall 1915, and State v. Paul Curtis, Nos. 431 and 432, Fall 1916, Independence County Circuit Court Record Book G, Independence County Courthouse, Batesville, AR; Preliminary Hearing, 1-2, 55-58.
} 
their responses and statements brief and vague, showing a clear reluctance to say anything that might implicate someone. The apparent fear and timidity shown by the witnesses only bolstered the prosecution's certainty that some sort of an organized murder plot had been schemed, but it also frustrated efforts to pin down sure-fire evidence to convict the suspects beyond a reasonable doubt. The day after the preliminary hearing concluded, on Sunday, March 26, an angry lynch mob assembled in Batesville and threatened to inflict their vigilante wrath upon the defendants, despite pleas from Jeffrey's oldest sons to allow the justice system to run its course. Sheriff Noah Harris took no chances and quietly transferred the suspects from the county jail to the state penitentiary in Little Rock for safe keeping. ${ }^{52}$

For the defense, however, tight-lipped witnesses were a blessing. Attorney Casey's attempt to draw attention away from the fact that most of the men present at the meeting were dipping opponents was unsuccessful. When questioned by the prosecution about their opposition to dipping, the defendants and witnesses who attended the tick meeting tried to elude the issue by stating that they were law-abiding citizens. For instance, when questioned about his opposition to tick eradication, farmer J.W. Burnett, who was also a Justice of the Peace in Relief Township, claimed that he had voted for the dipping tax and "dipped every time they notified me." When pressed further, however, Burnett finally admitted that "I can't say that I loved it" and was "opposed to it if I can get around it without disobeying the law." Other defendants and witnesses were more forthcoming in admitting that they opposed dipping when directly confronted but were sure to state that they respected the law. S.D. Lambert, the suspect at whose residence the

\footnotetext{
52 "State Wins First Round in Trial of Batesville Murder," Arkansas Democrat, March 26, 1922; "Farmers Held on Murder Charge," Arkansas Gazette, March 26, 1922; Preliminary Hearing, 6ff; Eddleman, "Who Killed Grandpa Charley?," 13.
} 
tick meeting had been held, even went so far as to claim that he actually supported the eradication program, although he received no support for this claim from the other defendants or witnesses. Still, despite its failure to dodge the anti-dipping issue, the defense benefitted from witnesses' reluctance to provide convicting testimony. ${ }^{53}$

For most observers, there was little doubt that some if not most of the men placed on the stand at the preliminary hearing had been involved in some way or at least knew who killed Charles Jeffrey. But the prosecution could not put its finger on any undisputable evidence to discern just who the guilty parties were. The Arkansas Gazette was confident that the antidipping assassins would be brought to justice, though, and assumed that the prosecution was just awaiting the proper time to show its winning hand: "It was evident throughout the trial that the prosecuting attorney was holding back most important and damaging evidence for use in the higher court, and seeking only to have the men held without disclosing the principal evidence and without producing the most important witnesses." ${ }^{.54}$

Ultimately, the prosecution was unable to come up with any new evidence strong enough for a conviction, and its principal evidence, the bloodhound trails and boot prints found near the murder scene, had too many holes to stand alone. Although details on the grand jury proceeding are absent from the historical record, the Independence County Grand Jury did indict Paul Curtis for first degree murder and six others as accomplices, George and J.W. Scoggins, Alfred Martin, James Lambert, Aaron Strother, and James McGee. But the prosecution failed to unearth the smoking-gun evidence needed to put the suspects away. Vying for more time, the prosecution

\footnotetext{
${ }^{53}$ Preliminary Hearing, 20, 25-26, 29, 32-33, 36, 39.

54 "Farmers Held on Murder Charge."
} 
managed to postpone the trial, originally scheduled for November of 1922, until the next April, but then it finally threw in the towel and the case was dropped from the docket. ${ }^{55}$

Just who pulled the trigger and who was involved in Jeffrey's murder will forever remain a mystery. Local tradition has reached several different verdicts, from beliefs that Curtis was hired by dipping opponents, as the prosecution argued, to claims that Curtis acted alone simply because he was a disreputable and morally-depraved character who was believed to have murdered before, to completely different explanations, such as one that explained that the dipping altercation only escalated a personal grudge between the Scoggins family and Jeffrey over a sexual-affair rumor, and others that attributed the murder to simple jealousy over Jeffrey's inspector position. According to Jeffrey family lore, Curtis confessed to the shooting years later while lying on his death bed and sent for Jeffrey's widow to beg for her forgiveness. ${ }^{56}$ But what is not disputable is the fact that the murder occurred amid heated and passionate resentment toward mandatory tick eradication during desperate times for small farmers in the Ozarks.

Even as the jailed murder suspects awaited their trial, violent resistance to cattle dipping persisted in Independence County. Three days after the murder, the federal tick inspector at Union Hill, located about fifteen miles southeast of Jeffrey's district, reported that his barn had been torched and burned to the ground by night riders. The inspector also turned over a threatening notice that had been posted at a local vat by dipping opponents and several other anonymous letters that he had received warning him that his life was in danger. Fearing for their

\footnotetext{
55 "Indicted for Murder of Charles Jeffery," Newark Journal, April 20, 1922; Independence County Circuit Court Record Book H; Mosier, "The 1922 'Tick War," 20-21.

${ }^{56}$ Susan Mosier, telephone interview with author, May 25, 2010; Mildred Thomas, telephone interview with author, May 28, 2010; Brian Jeffery, telephone interview with author, July 17, 2010; Eddleman, "Who Killed Grandpa Charley?," 19.
} 
lives, all of the federal tick inspectors in the "rebellious" mountains south of White River in Independence County temporarily resigned their posts, and the county tick eradication supervisor suspended mandatory dipping in the area until federal marshals could arrive to quell the violence..$^{57}$

But before the nine federal ex-servicemen ordered by local officials and hired by the BAI arrived to restore order and resume dipping, more violence erupted. On April 2, a few days after another local dipping vat had been destroyed, a band of about fifteen or twenty night riders set fire to the barn of a well-to-do farmer, the brother of a prominent local merchant, and a vocal tick eradication supporter, Dave Wyatt, in the Rosie community. Although a night watchman and several alarmed neighbors were able to fire off about thirty shots at the fleeing bandits, only one horse was apprehended. Forty-eight hours later, the belligerent night riders struck again. This time Wyatt and his brothers discovered the intruders before any property damage was done and unloaded a barrage of gunfire in their direction as they fled. One vigilante appeared to have been hit but was rescued by a fellow night rider before Wyatt and his gang could capture him. Law officers arrested five suspects within the next week, and they received grand jury indictments for night riding. ${ }^{58}$

\footnotetext{
57 "Barn Burning Figures in Probe of Murder," Arkansas Democrat, March 23, 1922; "Independence Tick Inspectors Resign," Arkansas Gazette, March 28, 1922.

${ }^{58}$ Strom, Making Catfish Bait, 177; "Night Riders Fired Upon; Take Flight," Arkansas Democrat, April 3, 1922; "Another Attack by Night Riders," Arkansas Gazette, April 5, 1922; "Indictments Returned," Arkansas Gazette, April 9, 1922. Personal property tax records indicate that Dave Wyatt and his family were comparatively more prosperous than other farmers in the area. Dave Wyatt, whose personal property records suggest that he was a rather diversified farmer who grew row crops as well as raised a few cattle (12), had a total personal property valuation of $\$ 2,430$. Compare this to the $\$ 720$ of the assessed personal property of W.F. Grady, the local merchant and most prosperous resident of Relief Township, the township in which the murder suspects resided, Personal Assessment and Tax Book-1921, Independence County Courthouse, Batesville, AR.
} 
The initial presence of federal marshals slowed violence considerably but did not end it entirely. The Arkansas Gazette printed a hopeful headline on April 12 that read, "Anti-Dipping War Crisis is Passed," although this turned out to be a premature claim. However, it seems that many dipping opponents who had previously formed large bands of "night riders" were no longer willing to risk being arrested or shot up by federal marshals. Ten days after the last encounter at the Wyatt farm, another tick eradication supporter in the Rosie community, Ira Castleberry, had his property targeted by what appeared to be a lone anti-dipping marauder. A federal marshal, accompanied by Castleberry and Wyatt, discovered the bandit slipping through some bushes on his way to set fire to Castleberry's barn and opened fire, but he escaped into the hills and eluded arrest. And a lone "firebug" returned to Dave Wyatt's farm several days later, the sixth attempt to destroy his "large barn," an area newspaper reported. A local police officer and Wyatt's two sons who were standing guard attempted to apprehend the man, but the surprised would-be arsonist bolted over a nearby gate, tearing half of his jacket from his body on the barbed wire as he barely escaped a bullet fired from the officer's revolver, and retreated into the woods. With this incident, violent resistance seems to have petered out, and the federal marshals oversaw the resumption of tick eradication in the area. ${ }^{59}$

Amid the chaos of the Independence County tick eradication rebellion, observers attempted to probe the reasons for such violent behavior. The Arkansas Democrat attributed the violence to a backward mountain culture. In this "rebellious district," claimed the Democrat, “...live a great many mountaineers, not a few being emigrants from other states, who up to a

\footnotetext{
59 “Anti-Dipping War Crisis is Passed," Arkansas Gazette, April 12, 1922; "Barnburners Again in Evidence at Rosie," Newark Journal, April 13, 1922; "Another Attempt to Destroy Barn," Newport Independent Weekly, April $28,1922$.
} 
certain point are illiterate, and do not keep abreast of the times. They apparently have not learned to adapt themselves to new conditions and new customs." Again, referencing a claim that Socialism predominated in the area, it charged that many of the dipping opponents "spend a large part of their spare time in preaching their Socialist doctrines to their neighbors and friends." Ultimately, however, "living in the mountains...they oppose a great many laws of the state and federal government, and especially such laws as interfere with their own personal freedom and bring extra expense or work upon themselves." "They feel that the [dipping] law places a restriction on their personal freedom." ${ }^{60}$

These last couple of sentences could just as well have been written by Claire Strom in her recent interpretation of yeoman resistance to federal tick eradication. Indeed, there is some reason to assume that dipping opponents in Independence County and elsewhere had come to resent such forms of government intervention and their seemingly unjust intrusions into their lives. Frustration toward federal tick eradication may have built upon considerable resentment toward the draft during World War I. Jeffrey's accused murderer, Paul Curtis, had unsuccessfully requested exemption from the draft on the grounds that his mother depended upon him for her livelihood. Another murder suspect, J.W. Scoggins, outright dodged the draft. When asked during the preliminary hearing in the Jeffrey murder case about his failure to report to the draft board during the war and where he hid out, Scoggins cussedly responded: "That is for me to know and you to find out."

\footnotetext{
${ }^{60}$ Arkansas Democrat, April 2, 1922.

${ }^{61}$ Paul Curtis World War I Draft Registration Card, Independence County, Arkansas, available at Ancestry.com; Preliminary Hearing, 40.
} 
At the root of such objections, however, was their perception that the prosperous and well-to-do were using government power for their own gain at the expense of less fortunate farmers' efforts to attain improved economic security. A close analysis of the dynamics of society and economy in the Hutchinson Mountain community suggests that the high cattle prices of the war years brought high hopes to a number of local farmers and their families. Historians have broadly identified yeomen as farmers who "filled the social and economic space between large commercial farmers and tenants." The common thread, they say, was that yeomen "bas[ed] their livelihood on subsistence agriculture" and "self-sufficiency." 62 But the small farmers on Hutchinson Mountain defy such simplistic characterization. While subsistence-oriented farming may have been the top priority of some, many saw economic opportunity in the cattle market, a chance to adapt and help alleviate their long struggles to sustain their family farms, and they speculated accordingly.

Historian Altina Waller notes in her study of the post-Civil War Tug Valley of southern West Virginia and eastern Kentucky — the setting of the infamous Hatfield-McCoy feud - that "the most important function of a father" in smallholder agricultural societies was "economic and social support." Fathers felt obligated to provide their sons at least "a modest start in life," and sons expected it of them. In this age of bleak prospects for small yeomen in America, high cattle prices during the war years afforded farmers and their sons on Hutchinson Mountain hope against "a frustratingly barren future.",63

\footnotetext{
${ }^{62}$ Strom, Making Catfish Bait, 43-44.

${ }^{63}$ Altina L. Waller, Feud: Hatfields, McCoys, and Social Change in Appalachia, 1860-1900 (Chapel Hill: University of North Carolina Press, 1988). Quotations on 58 and 39 respectively.
} 
Such prospects may have brought a few farmers into the community in the first place. S.D. Lambert, one of the murder suspects, sold his row-crop farm in the lowlands of Randolph County and purchased a small farm on Hutchinson Mountain in 1910 where he would move permanently around 1916 and become the community's largest cattle farmer. Lambert's eldest son, twenty-two year old James (also a murder suspect who was eventually indicted), had recently married and moved to a place of his own on the mountain by 1920 . According to the 1920 census, James owned his new home, and personal property tax records show that he had three head of cattle of his own, though he undoubtedly continued to work for his father on his farm. Lambert also had two other sons, twenty-one and nineteen, still living with him but soon to be leaving the nest, not to mention four younger children. So for Lambert, who, it is worth mentioning, had taken out a mortgage on his own home by 1920 , the cattle industry was vital to providing for his family's economic security. ${ }^{64}$

Lambert sought to capitalize on the record cattle prices of the World War I years. Although personal property tax records do not provide a full picture of market transactions, an analysis of herd sizes and assessment values of cattle reveal a great deal about yeomen and the national cattle market trends of the war and postwar years. In 1917, Lambert owned 30 cattle assessed at $\$ 300$. Plainly more than he needed for subsistence or self-sufficiency, they accounted for 38 percent of his $\$ 790$ total personal property valuation. In 1918, he enlarged his herd to 40 cattle, now listed at $\$ 600$, representing 67 percent of his $\$ 900$ total valuation. And in 1919, Lambert had 60 cattle assessed at $\$ 900$, which comprised 78 percent of his $\$ 1,150$ total

\footnotetext{
${ }^{64}$ Preliminary Hearing, 25; Manuscript Census Returns, Fourteenth Census of the United States, 1920, Population Schedules, Relief Township, Independence County, AR; Personal Assessment and Tax Book-1921.
} 
valuation. Doubling his herd in just three years and putting a disproportionate amount of his personal assets into cattle, Lambert was clearly banking on the beef market. ${ }^{65}$

But as the beef market plummeted after the war, Lambert felt the pinch. In 1920, Lambert's continued investment in the cattle market backfired. He had enlarged his herd to 80 cattle, but with the major decline in prices, the assessed value of his cattle had fallen from $\$ 900$ to $\$ 800$, even though his herd consisted of 20 more head than it had the year before. The following year, after an apparent effort to trim back a bad investment, Lambert owned 60 cattle that were now only worth $\$ 450$, and his total personal property valuation now slumped to $\$ 690 .{ }^{66}$ Although Lambert testified that he supported tick eradication and that others in the community were just "pushing me," it appears that he was simply attempting to save his own skin. Justice of the Peace Holmes was not convinced that Lambert favored dipping and that his arrest had been a mistake. Lambert, in fact, had organized the tick meeting in the first place and held it at his residence, and while other witnesses and defendants were careful not to implicate Lambert, no one supported his claim that he favored dipping. Although the grand jury apparently acquitted Lambert himself, his son James was one of the seven eventually indicted for the murder. Indeed, the Lamberts, who were probably the hardest hit by receding cattle prices, had the biggest and most expensive job of dipping their 60-plus cattle that roamed the open range and were undoubtedly among the most resentful toward tick laws. ${ }^{67}$

\footnotetext{
${ }^{65}$ Personal Assessment and Tax Book-1917; 1918; 1919.

${ }^{66}$ Ibid., 1920 and 1921.

${ }^{67}$ Preliminary Hearing, 25-26; "Indicted for Murder of Charles Jeffery." S.D. Lambert provided the most articulate testimony at the hearing and seemed to be well aware of the broader controversy over tick eradication. Having corresponded with both Inspector Jeffrey and his superior, Lambert had likely heard the standard line from eradication officials that dipping would prove beneficial to cattlemen in the end. All testimony said that he not only called the meeting and held it at his barn, but that he gave a speech (although no one "could remember" what he
} 
Other local farmers felt the squeeze of declining beef prices and felt the sharper pains of cattle dipping by the 1920s. Even though they did not have the capital to invest in the cattle market to the extent that Lambert did, they felt the crunch nonetheless. George Scoggins, who was eventually arrested along with his brother and son for involvement in the murder, seems to have welcomed the opportunity to capitalize on higher cattle prices, possibly needing to help his son J.W., who was in his early twenties in 1917, get a start in his adult life. In 1917, Scoggins owned 24 cattle assessed at $\$ 300$, which represented just under half of his $\$ 610$ total personal property valuation. With higher offers from cattle drovers, Scoggins appears to have sold not only his calves but a few cows as well, as his herd was reduced to 18 head in 1918, although with the increase in cattle values his reduced herd was still listed at \$270. By the next year, Scoggins may have begun attempting to once again build up the size of his herd, either by purchasing a couple of cows or by keeping a couple of heifers; he owned 20 cattle which he reported (conservatively in light of cattle values reported by other local farmers) to be worth $\$ 300$, accounting for 56 percent of his total personal property valuation. ${ }^{68}$

But Scoggins, who was significantly less fortunate than Lambert, seems to have been more concerned with immediate cash returns, despite slumping prices by 1920, than with looking ahead to long-term investments in cattle. According to 1920 tax records, Scoggins's herd had been reduced to 15 head, now only worth $\$ 150$. By the time prices bottomed out in 1921 ,

said) and joined those "opposed to dipping" who were called to congregate together. Lambert claimed that he did this only because he wanted to file an injunction to suspend dipping because he "fear[ed]" the dipping opponents and their threats, but he admitted to being "pretty close friends" with fellow suspect James McGee, an openly ardent opponent of dipping who helped him call together and lead the tick meeting.

${ }^{68}$ Personal Assessment and Tax Book-1917; 1918; 1919. J.W. Scoggins does not appear in the 1920 census, perhaps because he had hidden out to avoid the draft, but George testified that J.W. or "Bill," who was thirty-eight when the 1930 census was taken, was his son, Preliminary Hearing, 38-40, 47. 
Scoggins's 18 head of cattle were assessed at only $\$ 135 .{ }^{69}$ Although Scoggins did not risk as much — probably because he was less able—as Lambert in the cattle market, falling cattle prices adversely affected him and must have made the troubles and expense of dipping his now lessvaluable cattle more irritating.

The trends of the national cattle market also affected those farmers who had only a few head of cattle or had begun with none at all. Aaron Strother, who was indicted as an accessory for harboring suspect Paul Curtis the night before the murder, owned 4 cattle assessed at $\$ 50$, which accounted for $\$ 120$ of his total personal property valuation in 1917 , and in 1918 Strother had 5 cattle worth $\$ 75$, representing exactly half of his total valuation. These numbers were the same in 1919, but in 1920, Strother had increased his small herd to 8 cattle, although their assessed value grew to only $\$ 80$. In 1921 , amidst falling prices, he had accumulated 11 cattle that were now only worth $\$ 60 .^{70}$

Like Strother, C.W. Hembry, who was arrested but not indicted by the grand jury, attempted to improve his economic security by investing in cattle but came into the game too late for it to pay off. In all likelihood, poorer farmers like Strother and Hembry decided to try to invest their meager resources in cattle when the market slumped and cattle could be bought more cheaply in 1920 and 1921, expecting that the market would soon recover. Hembry, a poor farm laborer with no personal property to assess in 1917 or 1918, appears to have saved some of his wages and bought his first 3 cattle, worth $\$ 45$, in 1919 . He increased his holdings to 10 cattle in 1920 , but more than tripling his herd only slightly doubled his cattle value to $\$ 100$. Tax records

\footnotetext{
${ }^{69}$ Personal Assessment and Tax Book-1920; 1921.

${ }^{70}$ Ibid., 1917; 1918; 1919; 1920; 1921.
} 
from 1921 suggest that he had stopped investing in cattle, but his 10 head were now only assessed at $\$ 70$. Even the suspected Socialist leader of the community, James McGee, who had only 1 cow in 1917 , owned 4 head by 1921 , indicating that he was probably now selling at least a couple of calves for cash. ${ }^{71}$

Young smallholder Alford M. Martin, who was also indicted for Jeffrey's murder, had likewise invested his limited resources in raising cattle. Martin had 6 cattle in 1917 worth $\$ 75$ and enlarged his holdings to 11 head worth $\$ 165$ in 1918 . The next two years Martin apparently took advantage of high offers from cattle drovers and sold not only the calves but a few cows as well, as he reported 7 cattle in 1919 and 6 in 1920. But Martin sought to reinvest his cattle profits the following year as prices slumped, probably assuming that this was only a temporary dip in the market and hoping to be in good shape to prosper when it rebounded. In 1921, Martin owned a much larger herd of 18 cattle, but the continuing dive in beef prices meant that his much larger herd was now only assessed at $\$ 125$, which was $\$ 25$ less than what his 7 cattle had been worth in $1919 .^{72}$

As for the most prosperous resident of the community, former Justice of the Peace W.F. Grady, while he may not have particularly liked dipping, his anger toward tick eradication appeared less intense. Grady attended the tick meeting but claimed that he took a neutral stance toward dipping and favored adhering to the law. The prosecution, in fact, discovered that Grady had been on his way to speak with Inspector Jeffrey the morning that he was killed and suggested that his intended visit was to warn Jeffrey that his life was in danger. Although Grady

\footnotetext{
${ }^{71}$ Ibid. Census records list Hembry as a farm laborer in 1910 and a general farmer in 1920, Manuscript Census Returns, Thirteenth Census of the United States, 1910, Population Schedules, Relief Township, and Manuscript Census Returns, Fourteenth Census of the United States, 1920, Population Schedules, Relief Township.

${ }^{72}$ Personal Assessment and Tax Book-1917; 1918; 1919; 1920; 1921.
} 
denied that this was his intention, insisting that he just wanted to "talk to him about some rules about dipping," it seems that he was less militant than others in the community toward compulsory dipping. ${ }^{73}$ The difference, it seems, is that unlike others in the community, Grady's economic security had improved significantly by 1922 in spite of the farm crisis.

By community standards, Grady had been a little-better-than-average farmer until 1920 when he became the local merchant. By 1922, Grady had been appointed to the coveted position of postmaster at Hutchinson. Personal property tax records show that Grady owned 13 cattle worth only $\$ 85$ in 1921 , but they represented only 12 percent of his $\$ 720$ total valuation. While neighbors struggled with declining cattle prices and the trouble of dipping in 1921, Grady purchased the community's first automobile. ${ }^{74}$ In short, unlike his yeoman neighbors, Grady had much less to panic about.

For disaffected farmers in the community, there was much to resent about Charles Jeffrey. The owner of two farms in the area, Jeffrey, while never expanding the size of his livestock herd, must have enjoyed the unprecedented prices he got for his calves during the war years. But the pressures of falling beef prices after the war did not affect him like it did poorer neighbors who depended on cattle for an essential part of their families' income. In addition to his farms, Jeffrey owned a blacksmith shop in Jamestown and a sawmill, and he held a federal contract to haul the mail from Batesville to Heber Springs for the U.S. Postal Service. During the war, Jeffery had also managed to obtain a government contract to provide lumber for the U.S. war effort. Ironically, versions of local tradition say that Jeffrey's early opposition to cattle

\footnotetext{
${ }^{73}$ Preliminary Hearing, 21-25, 28.

${ }^{74}$ Personal Assessment and Tax Book-1917; 1918; 1919; 1920; 1921.
} 
dipping was well known throughout the area. Jeffrey's opinion on the matter changed dramatically, however, after the county's federal tick eradication supervisor, W.H. Lendreth, appointed him to a salaried inspector position in his locale. ${ }^{75}$

Already enraged over the pains of dipping, tick eradication opponents likely despised taking orders from a man who had only recently sided with them against an unnecessary law that only stood to benefit the prosperous and well-to-do. Such antipathy toward officials was widespread anyway. The Arkansas Democrat noted that "one of the public arguments made by those who oppose and fight against the dipping law is that it is gotten up to give a select few good paying jobs." ${ }^{, 76}$ A Stone County man also mockingly detested the greed of the tick program:

This will be a lonesome old place to live when the tick eradicators get all the...ticks eradicated. They may eradicate for a thousand years and there will not be any difference in the amount of ticks. The one Tick they are after is a big round tick. I call it a Dollar. When they are all eradicated, then the ticks [money] will be gone...The poor we have with us always. ${ }^{77}$

Resentment, then, must have been especially strong toward Jeffrey, the man after the "ticks" in this Independence County community, and this literally made him a walking bull's-eye among desperate and furious farmers who probably felt that he had sold himself to the devil.

\footnotetext{
${ }^{75}$ Ibid.; Jeffery interview. Charles Jeffrey did not reside in the immediate community of his murder suspects but in nearby Greenbrier Township, Manuscript Census Returns, Fourteenth Census of the United States, 1920, Population Schedules, Greenbrier Township.

${ }^{76}$ Arkansas Democrat, April 2, 1922.

${ }^{77}$ Melbourne Times, April 20, 1923.
} 
The myth of a distinct culture of feuding and violence in the southern mountains has been laid to rest. "Vigilantism," however, "had long been part of the fabric of rural America," including the Ozarks. ${ }^{78}$ Indeed, evidence suggests a significant presence of vigilante activity in the Hutchinson Mountain community even before the dipping rebellion in the early 1920s. In 1915, “an organized band known as Night Riders” on Hutchinson Mountain set their sights on one Charley Gilbert, a "loafrer [sic]" and violator of community mores. In a threat-letter signed by the group, including George Scoggins and W.F. Grady, the vigilantes scolded Gilbert for accusing the Scogginses of stealing a pig and "tell[ing] things that you no is a dam lye." The vigilantes also warned Gilbert, who “don't do anything but loafrer and round over the woods and cuting peoples...trees," that they "came dam near catching you cutting some bodys fence line." And, like other contemporary vigilante groups such as the Ku Klux Klan, these "Night Riders" appeared to be the self-appointed moral police of their community. They warned Gilbert that "the next time we catch you fucking old red Elembrough we are going to shoot your god dam ass off of you." Accompanied by some "drawings of vulgar pictures" and their signatures, the vigilantes issued their final warning: "now the shot gun boys are coming after you and you had better stay out of the woods here... unless you take some of them hoars along with you to pick the shot out of your dam ass."79

Given the circumstances of the Hutchinson Mountain community during the 1910 s and 1920s, the presence of "vigilante justice" is not surprising. As Waller has observed in the Hatfield-McCoy affair, southern mountaineers who had previously been almost exceptionally apt

\footnotetext{
${ }^{78}$ See Waller, Feud; Brooks Blevins, "The Arkansas Ghost Trial: The Connie Franklin Case and the Ozarks in the National Media," Arkansas Historical Quarterly 68 (Autumn 2009), 251.

${ }^{79}$ State of Arkansas v. George Schroggins, No. 331, Fall 1915, Independence County Circuit Court, Independence County Courthouse, Batesville, AR.
} 
to take their grievances into the courtrooms might decide to take extra-legal measures when they felt alienated from the legal system and feared that justice might not prevail. ${ }^{80}$ For farmers in the Ozarks, the legal system was fully backing policies that impeded important aspects of their livelihood. In addition to tick eradication and the military draft, hunting, fishing, and trapping regulations and enforcement against moonshining also confronted these hill farmers in the 1910s and 1920s, which undoubtedly aroused suspicion toward the legal system. ${ }^{81}$ They might have justified resisting dipping laws by extra-legal means as a fight against well-to-do, selfish interests that were denying their rights to participate freely in an agricultural market and undermining their quest for economic security and prosperity.

Examining the changes wrought in the community during the 1920s after dipping resistance was overpowered and quelled by federal force leaves little wonder why so much passion and emotion surrounded the hopes of cattle farming and the obstacles of mandatory tick eradication. Determined efforts to eradicate ticks continued after resistance culminated with Jeffrey's murder in 1922, but the prices that Arkansas cattle farmers received continued to fall even lower in succeeding years, bottoming out at $\$ 2.80$ per 100 pounds in October of 1924 . Prices gradually rebounded in the last years of the decade, climbing to over $\$ 7.00$ in the fall of 1928, but this was just in time to be sapped by the Great Depression of the 1930s and long after a

\footnotetext{
${ }^{80}$ Waller, Feud, 42-52, 73-76.

${ }^{81}$ On game and fish laws, see Keith Sutton, e.d., Arkansas Wildlife: A History (Fayetteville: University of Arkansas Press, 1998), 61-66. On liquor law enforcement, the Arkansas Gazette reported on April 18, 1922, that sixty of seventy-six grand jury indictments in Independence County involved prohibition laws, "Five Indicted in AntiDipping War."
} 
great many young farmers had likely been forced to flee the economically distressed community. $^{82}$

The decade of the 1920s was a period of significant population exodus from the rural South, including the Ozarks. Small farmers were typically "pulled" by urban opportunities and "pushed" by agricultural distress. ${ }^{83}$ Typical outmigrants from Hutchinson Mountain were young men whose hopes of settling down near their families on farms of their own had likely been crushed by their and their fathers' inability to profit enough from cattle farming to give them a secure start - a hope they had fully come to embrace during the prosperous World War I years. By 1930, although the community's largest cattle farmer, S.D. Lambert, had been able to keep his farm and home that was mortgaged in 1920, all but one of his older sons, including murder suspect James, had left the community. Even though he still had enough room on his small farm for one twenty-eight-year-old son, Lambert was apparently unable to help this son build or buy a place of his own, as he still lived with his parents in 1930. In addition, Lambert also had a twenty-five-year-old daughter at home in 1930, which may also reflect the lack of marrying-aged men in the community. ${ }^{84}$

Census records for 1930 indicate that it was usually only those young men who could step in to fill their fathers' shoes on small family farms that were able to stay in the community. J.W. Scoggins, for instance, was still listed as a farm laborer in the community in 1930 but had

\footnotetext{
${ }^{82}$ USDA, "Prices Received by Farmers for Beef Cattle," 38. Exact population change is difficult to discern because Ancestry.com combines neighboring Liberty Township with Relief in the 1920 census in its database, but the two townships together experienced a twenty-percent population loss between 1920 and 1930, Manuscript Census Returns, Fourteenth Census of the United States, 1920, Population Schedules and Manuscript Census Returns, Fifteenth Census of the United States, 1930, Population Schedules.

${ }^{83}$ On outmigration from the rural South, see Jack Temple Kirby, Rural Worlds Lost: The American South, 19201960 (Baton Rouge: Louisiana State University Press, 1987), 309-333.

${ }^{84}$ Manuscript Census Returns, Fifteenth Census of the United States, 1930, Population Schedules, Relief Township.
} 
likely taken over the leading role in running the family farm from his aging father. Paul Curtis also appears to have taken over his mother's small farm after his stepfather died and his mother moved in with her daughter and son-in-law. By 1930, Curtis had married a widow, had two young children, and was renting a house in the community. ${ }^{85}$

Other young men appear to have realized that their best bet was to abandon the community. Alford M. Martin, a murder suspect and a young, up-and-coming farmer who had invested a great deal in the cattle market, had moved his family from their small Hutchinson Mountain farm by 1930. But the young farm laborers who counted on their fathers and families to help set them off on a secure and successful farming career likely suffered the worst. Frank Holland, a key suspect in the night riding activities and property destruction at the Dave Wyatt farm in Rosie, was undoubtedly feeling desperate in the early 1920s. To make ends meet, Holland and his wife and two children were living with his wife's parents in 1920, where Holland worked for meager wages on his father-in-law's small farm. By 1930, with hopes of making a good life in the hills of Independence County snuffed out, Holland had moved his family to a rent-house in White County where both he and his wife worked for wages as farm laborers in the cotton fields. ${ }^{86}$

The anti-dipping rebellion and assassination of Charles Jeffrey in the hills of Independence County in 1922, then, was the culmination of angry resentment toward what yeomen perceived as an unjust law during a period of great desperation and anxiety. Small

\footnotetext{
${ }^{85}$ Ibid.

${ }^{86}$ Manuscript Census Returns, Fourteenth Census of the United States, 1920, Population Schedules, Relief Township, and Manuscript Census Returns, Fifteenth Census of the United States, 1930, Population Schedules, Relief Township. The Hollands lived in Harrison Township in White County in 1930, Manuscript Census Returns, Fifteenth Census of the United States, 1930,Population Schedules, Harrison Township, White County, AR.
} 
farmers struggled to ensure their families' economic security and relied greatly upon the profitability of cattle raising to do so. The high cattle prices of the World War I years gave them high hopes, but these were shot down as beef prices plunged below pre-war levels after international demand subsided following the war.

The panic and desperation that resulted from the agricultural recession coincided with stepped-up efforts by supporters and administrators of the federal tick eradication program. For yeoman cattle farmers, the mandatory dipping laws administered by and for local agricultural elites were costly and troublesome, which was all the worse since they stood to reap none of the benefits from dipping. Dipping laws had always impeded their ability to fully enjoy the commercial rewards of raising cattle, but an evermore stringent policy that prevented farmers from selling their "ticky" cattle altogether during the dire postwar years transformed resentment into violent hostility. Most yeomen seem to have rebelled against the government program because it obstructed their ability to participate in the national cattle market at a time when their hopes were high and benefitted only elite cattleman at their expense. They rarely resisted out of some authority-defying cultural impulse or because they had no stake in commercial agriculture. Desperation, discontent, and resentment spawned an explosive environment of resistance that was ripe for tragedy.

Despite their efforts to adapt, backcountry Ozarkers continued to confront the uneven consequences of efforts to remake the region in accordance with the New South visions of capitalist progress - and the government power that typically backed these visions. Like the rest of America, the "Roaring Twenties" brought ever greater excitement and enthusiasm about the potential for business growth and economic development in towns, commercial centers, and more prosperous agricultural locales in the region. But the prosperity of American capitalism 
failed to reach many poor and middling backcountry folks. Their struggles to sustain smallholder farming and to halt the deterioration of their rural communities continued while urban America boomed in the 1920s. The agrarian populist ethic about the role of government, meanwhile, remained alive and well in the rural Ozarkers. When the bottom began to fall out of American capitalism in 1929, unleashing widespread cries across the nation for new government interventions to promote greater economic democracy, Ozarkers attempting survive the crises of the Great Depression would join the popular demand for a New Deal. With national political leaders more receptive than ever to new roles for government that promised to bring more fairness and security to the American economy, many populist Ozarkers hoped that the more powerful liberal state might finally help bring justice to the rural backcountry. Little did they know that they would be making the last big stand in the Ozarks for the agrarian-populist ethic and its vision for government's role in the economy. 


\section{Chapter Six}

\section{Bring On the Dam Progress}

Local and regional spectators gathered on the hills overlooking the White River near the Baxter-Marion county line on a hot and humid July morning in 1952 for a celebration that, according to the Baxter Bulletin, area residents had long been "feverishly preparing for." President Harry Truman arrived to help dedicate two hydroelectric dams that had been authorized by the Flood Control Acts of 1938 and 1941 and constructed on the White River and its North Fork tributary by the U.S. Army Corps of Engineers at a total cost of $\$ 134.6$ million. Truman and his entourage first stopped for a smaller ceremony at the Norfork Dam, the Corps's pilot project in the region which had been completed in 1943. Then they headed to the recentlyfinished Bull Shoals Dam for the main event. Sporting a white suit and a panama hat that shielded his head from the blistering sun, Truman commended his and his beloved predecessor Franklin D. Roosevelt's progressive supporters and their representatives in Congress for their valiant efforts in seeing these government projects to completion.

In his dedication speech, the Missouri-born president spared few words in blasting the conservative political detractors and lobbyists of private power companies who had long fought these public projects, which promised to bring much-needed flood control, cheap hydroelectric power, and economic development to the rural Ozarks. Despite the "private selfishness" of these conservatives and special-interest lobbies, said Truman, the "people" and their government had prevailed. "These dams belong to the people and we are here to dedicate them to the service of the people," he exclaimed. Truman promised the region's residents more of these projects from their federal government in the coming years, vowing that "some time or another, we're going to 
get it done, in spite of all the opposition." "If it hadn't been for the New Deal and Fair Deal of the last 20 years," he reminded the audience, “you wouldn't have these dams and these improvements on these other rivers like it. Put that in your pipe and smoke it." ${ }^{1}$ Truman's rhetoric and its popular reception indicated the persistence of the populist ethic in the rural Ozarks. Yet his dedication speech also hinted at the significant, watershed changes that government had helped create in the region by mid-century. It pointed to the ultimate victory of regional elites' New Ozarks vision over backcountry folks' struggle to preserve a small farm society.

Like most Americans, rural Ozarkers had remained cautious about government power as they entered the dreary 1930s. For rural families in the Ozarks struggling to make ends meet on the nation's capitalist economic periphery, this held especially true, where, as the novelist Daniel Woodrell puts it, "there has never been much belief in the essential fairness of a social order that answers most readily to gold." Some Ozarkers, scarred and weary from troubled encounters with various tentacles of government in the past, undoubtedly harbored no hope for potential political change, "assum[ing] the installed powers were corrupt and corruptible, hence to be shunned and avoided, except when you couldn't and must pay them."” Like most other Americans, however, a majority of hill folks continued to demand reform and insisted that their public institutions cease catering to "special interests" and serve "the people" instead, whether this meant drastic and unprecedented expansions of government or not.

\footnotetext{
${ }^{1}$ Truman speech quoted in South Shore Foundation, A Pictorial History of Bull Shoals Dam and the Town of Bull Shoals (Flippin, AR: South Shore Foundation, 2002), online at http://www.southshore.com/bsdam.htm, accessed October 24, 2013.

2 Daniel Woodrell, "How Much of the Ozarks is in Me?," reprinted in the "Reading Group Guide" of Daniel Woodrell, The Death of Sweet Mister (2001; New York: Back Bay Books, 2012), 4.
} 
Thousands of hill folks hoped that Franklin D. Roosevelt's and his liberal successor's promise of economic justice might finally reverse the deterioration of family farm life and supported most of the groundbreaking growth of the liberal American state's power that had occurred during the 1930s. Despite the drastic enlargement of federal authority that vowed to justly defend a cooperative commonwealth, however, New Dealers and Fair Dealers generally adhered to the American traditions of "federalism" and "local control," vesting most of the government's newfound power and resources in the hands of regional and local elites. These New Ozarks elites had little interest in saving smallholder farms but utilized the government's power and resources to promote industrialization and agribusiness in the region through massive infrastructure projects like dam building.

With many more destitute and desperate than ever, most backcountry Ozarkers, with the exception of some who stood to be forcibly uprooted from their land for the projects, backed the federal government's dam building schemes, eager to take advantage of the public works jobs they provided, however temporary they would be, for much-needed income to supplement their distressed farms. Regional and local elites promised, moreover, that the completion of the giant hydroelectric dams and lakes would bring transformative opportunities to the Ozarks that would raise all boats, including the revival of a vibrant small farm economy. This proved to be wishful thinking, though. The government's dams and lakes remade a handful of towns into prosperous tourism, recreation, retirement, and light industrial centers, but the prosperity failed to ripple out into the countryside, where rural depression persisted through America's booming World War II and postwar eras and thousands of Ozarkers fled their communities each year.

Already in the throes of an exceptionally severe rural depression since the agricultural market collapse of the early 1920s, backcountry Ozarkers scraped for survival in their rural 
communities and demanded greater justice from their government officials as their situations deteriorated even worse with natural disasters and the bust of the larger national economy between 1927 and 1930. Disastrous floods swept the broader Mississippi River Valley in 1927 and decimated many farms in the narrow valleys of the Ozarks. Then, after national and international markets began tanking in the fall of 1929, devastating droughts arrived to wreak more havoc upon the Ozarks and the rest of the western South during the early- and mid-1930s. The editor of the Mountain Wave in Searcy County sought to lift the spirits of benighted farmers in his section of the Ozarks with a joke about a conversation between two poor corn farmers. "Well, John...is your corn sufferin' because of the heat?," one of them asked. "No," said the other, "it ain’t suffering now, but it suffered a lot before it died." ${ }^{33}$ His dry humor aside, everyone realized that their longstanding farm crisis had worsened. It was high time, many believed, that their government help do something about it.

At the state level, political leaders waged a major battle over tax reform in 1929. Governor Harvey Parnell, under pressure from the Arkansas Education Association and its plan to provide state subsidies to help poor and cash-strapped school districts in rural areas, proposed that the state legislature adopt a progressive income tax and other "privilege taxes" on corporations to raise revenues primarily for a school equalization program. Faced with heated opposition from Arkansas business interests and their political representatives, Parnell and the plan's supporters in the state legislature compromised to pass a less progressive measure, but one that included a limited income tax and a school equalization fund, nevertheless. Despite the compromise, conservative political leaders and industrial boosters who claimed that "Arkansas

\footnotetext{
${ }^{3}$ Marshall Mountain Wave, September 21, 1934.
} 
Cannot Go Forward Under Socialistic Taxation Dictated by the Organized State School Group" kept up their fight to repeal the tax altogether. Populist rural voters, however, finally defeated conservatives' efforts to repeal the state income tax at the ballot box in a statewide referendum. ${ }^{4}$

The battle over more progressive state taxation hinted at the broader political expressions of rural populism arising more forcefully as the pains of depression mounted nationwide calls for economic and government reform. As the greater intensity of depression set in, agrarian-populist politics crested in the Ozarks in the early 1930s. In 1932, the Arkansas Farmer featured an article proclaiming that "Prosperity Must Start at the Bottom," demanding a greater role for government to ensure that farmers get "a just share." "Will we stand by our time-worn prejudice that supply and demand must rule agricultural prices (when we know that it does not) and thus permit a complete collapse[?]" it asked its rural readers. Since at least the 1890s, many small farmers in the Ozarks had answered no to this question, asserting that a new role for government was long overdue. Thus, most rural Ozarkers applauded Franklin D. Roosevelt's New Deal and his liberal-progressive supporters' calls for relief, recovery, and reform, hoping the new designs of government power might insure better security and opportunities for their struggling families. ${ }^{5}$

Stronger government regulations in the economy and a more just redistribution of wealth and power, many Ozarkers believed, were not only the right courses for political action but for the greater cause of moral decency and Christian principles. As national observers offered various autopsy reports to explain what had happened to the national economy and what was

\footnotetext{
${ }^{4}$ See Ben F. Johnson III, ““All Thoughtful Citizens': The Arkansas School Reform Movement, 1921-1930,” Arkansas Historical Quarterly 46 (summer 1987); and Ben F. Johnson III, Arkansas in Modern America, 1930-1999 (Fayetteville: University of Arkansas Press, 2000), 8-9. Johnson explains that "owing to an extraordinarily high personal exemption in the income tax schedule, the only individuals subject to taxation were those earning the equivalent of 500 percent of the Arkansas per capita income."

5 "Prosperity Must Start at the Bottom," Arkansas Farmer, reprinted in Mountain Wave, September 23, 1932.
} 
needed to fix it, one Ozarks newspaper printed a "Two-Minute Sermon” by minister Thomas Hastwell who declared that the sin of "Greed" had caused the Great Depression. "Because of greed there has grown up in this country an autocracy of wealth by which a few control and manipulate the business of the nation to their further enrichment," he explained. "The only lasting remedy," said Hastwell, "is the curtailment of greed-the larger flow of the national wealth into the hands of the mass purchasers, a more liberal application of the live and let live doctrine, a closer adherence to the tenents [sic] of the Golden Rule." Many backcountry Ozarkers in the 1930s undoubtedly agreed with Hastwell's motion to "go back to the teaching of Christ to find the permanent remedy for the depression" and economic justice, just as their populist-progressive and agrarian-socialist fathers had. ${ }^{6}$

Even those areas that had remained strongholds of Mountain Republicanism since the Civil War in what had become a one-party state showed significant support for the New Deal and its populist-liberal supporters across party lines, bucking against, as they typically had in the past, the national G.O.P.'s conservative Eastern establishment. In 1932 Roosevelt carried Searcy County, home to some of the most loyal Republican voters in Arkansas, where many applauded his plans for "corralling the bulls of Wall street" and compared him to his fifth cousin, the progressive Republican Theodore Roosevelt. Even the liberal Democratic nominee for the Senate, Hattie Caraway of eastern Arkansas, who became the first woman ever elected to the

\footnotetext{
${ }^{6}$ Thomas Hastwell, “Two-Minute Sermon," Mountain Wave, April 26, 1935. Throughout the next several pages, I cite a disproportionate number of articles and opinions expressed in Searcy County's Mountain Wave, though, it is important to note that its political positions generally represented those of most other local newspapers in the region. In fact, my assumption is that Searcy County's local newspaper, though it tended to lean toward supporting the Democratic Party, perhaps best represents popular opinions in the region since that county remained one of the most competitive two-party areas in Arkansas. In other words, an editor sympathetic to the Democratic Party might have taken special care to cover issues that he felt would best appeal to his rural readers across party lines and perhaps gain political support for Democrats from populist Republicans in the county.
} 
U.S. Senate, made an impressive showing in Searcy County against the more local Republican candidate, John W. White of Russellville. Caraway's narrow loss in Searcy County by a mere 35 votes is noteworthy, especially since her and the nationally-known Louisiana populist Huey Long's campaign tour only skirted a few towns along the southern rim of the Arkansas Ozarks. Caraway, who succeeded her late husband in the Senate, appealed to rural and laboring voters who saw her as a "great champion of the rights of the little man" and "against encroachments upon their rights by the more privileged." Left-leaning economic populism tended to cut across party lines in the 1930s Ozarks, just as it had in the past. Even many of those who refused to vote for FDR and his New Deal supporters tended to demand that their government step up to take on "this combine of money grubbing hogs and for God sake do something to remedy this situation," as one loyal Republican put it. ${ }^{7}$

More praise than criticism chimed from the Arkansas Ozarks in response to the new Democratic administration's and the U.S. Congress's ambitious and unprecedented efforts during FDR's first hundred days in office in 1933. In late June local newspapers remarked about the "Splendid Record" achieved by the special session of the seventy-third Congress, "passing every vital bill submitted by the President and starting the government on new enterprises." Reports on the removal of the U.S. dollar from the gold standard, "far-reaching" regulations of the banking industry, the imposition of new progressive taxes to raise federal revenues, the creation of the "country's biggest public construction program," the "first federal large scale direct relief grants," and the granting of new federal authority and money "to boost farm prices" and provide

\footnotetext{
7 “Official Returns," Mountain Wave, November 18, 1932; "F.D.R. Excels Teddy in Another Respect," ibid., February 9, 1934; "living Up to the Caraway Tradition," ibid., June 9, 1933; J.H. Whithen to Governor H. Parnell, February 10, 1931, Harvey Parnell Papers box VI, folder 177, Arkansas History Commission, Little Rock. On Hattie Caraway and Huey Long's 1932 campaign tour in Arkansas, see David Malone, Hattie and Huey: An Arkansas Tour (Fayetteville: University of Arkansas Press, 1989).
} 
much-needed agricultural relief sounded promising to rural populists in the Ozarks who had long called for such reforms. To be certain, some Ozarkers continued to remain suspicious. The editor of Yellville's Mountain Echo, for instance, had warned his readers during the devastating drought of 1930 to "make every effort possible to take care of himself before assistance from any source is given. The individual who sits down for this relief will doubtless have a long, hungry wait." Considering the vast blunderings and inadequacies of federal and state relief in 1930 and 1931, this was probably sound advice, regardless of politics. ${ }^{8}$ But even the most skeptical of rural Ozarkers, as historian Brooks Blevins points out, "seemed quiet, forlorn, and resolved to accept" the new actions taken by Washington. ${ }^{9}$ More optimistic Ozarkers hoped that the government's new measures might finally help bring security and opportunity to their rural families and communities. The promise of the New Deal even inspired the radical agrarian Sam Faubus, who had revived the local Socialist Party chapter in Madison County in the early 1930s. In fact, Faubus, says his biographer, "became a Democrat in the 1930s and remained loyal for the rest of his life."10

Early New Deal programs provided significant relief for many desperate families in the rural Ozarks. A few days after Christmas in 1933, Marshall's Mountain Wave proudly reported that "Your Uncle Sam Plays Santa Claus" and commended "the exhilarating effects of the CWA [Civil Works Administration] program...throughout the state," including the twenty-two projects already approved for Searcy County which were set to spend more than $\$ 73,000$ to employ local

\footnotetext{
${ }^{8}$ Mountain Echo, August 28, 1930, quoted in Blevins, Hill Folks, 110; Johnson, Arkansas in Modern America, 9-11. ${ }^{9}$ Blevins, Hill Folks, 110.

${ }^{10}$ Tom Wagy, “Little Sam Faubus: Hillbilly Socialist,” Arkansas Historical Quarterly 53 (Autumn 1994): 280-281.
} 
labor. ${ }^{11}$ In addition to a host of federal public works projects, including a popular Civilian Conservation Corps camp that provided much needed employment for young men, the Searcy County newspaper and others throughout the region hailed the important relief that federal agricultural programs and payments were bringing to a number of farmers in the region. By November 1934, federal agricultural programs had contributed more than $\$ 100,000$ in benefits to farmers in Searcy County, though uneven distribution soon became a point of contention among rural folks. ${ }^{12}$ Despite the heavy government spending that these programs and others required, the FDR administration's progressive taxation policy typically met with populist approval, because it "plugs loopholes by which many rich tax dodgers have heretofore escaped" and "really lightens the tax on the little man, but puts a higher rate on large incomes." After all, as one county newspaper put it, since "more than one hundred thousand millions of dollars" had already been lost since the Depression began, the U.S. "can well afford another hundred thousand millions to get out of the depression, if that is necessary." Despite the Depression's devastating impact to the national economy, the paper explained, "this isn't any little country or any poor country"; while it might seem like a lot of government money, it really amounted to a mere drop in the bucket to big wheels like "John D. Rockefeller" if they were only made to pay their fair share. ${ }^{13}$

Some Ozarkers passionately defended the administration against conservative criticisms of the government's increased role in the economy. Wayne Phillips, a former Ozarker who had relocated to Stigler, Oklahoma, penned a letter back to the newspaper editor in his home county

\footnotetext{
11 "Your Uncle Same Plays Santa Claus,” Mountain Wave, December 29, 1933; "CWA Projects in Full Swing in Searcy County," ibid., January 5, 1934.

12 “C.C.C. Camp Proposed for Searcy County,” ibid., August 25, 1933; “Over \$100,000 in Benefits to Local Farmers," ibid., November 16, 1934.

${ }^{13}$ Ibid., February 23, 1934; ibid., June 22, 1934.
} 
in 1934 in which he embraced the "entirely new concept of the function and duty of government" that the New Deal exhibited. "Traditionally, our government was supposed to do little in time of depression except keep the tracks clear for such revival as private industry might be able to bring about," wrote Phillips. "Now its responsibility is to provide jobs for the people." "While our Federal, or central government, is growing stronger,” he suggested, “...it may be correct to say that we shall have to admit that the old Jeffersonian concept of government no longer is applicable. At least we are getting better adjusted to our environment." He even wondered if it might work best if the federal government took over America's public education system from the states and localities. ${ }^{14}$

In response to those conservatives who argued that an expanding government was creating a culture of dependency and destroying Americans' work ethic, one local newspaper editorial assured readers that "the aid that these men received during the hard times is not the thing that spoils them." There had always been those who "were of little use before the depression came," after all. "The depression is merely going to develop the qualities that are already there the same as any adversity does." Another editorial commented that "we don't think much of the complaint of the fellow who insists that the government should not get into business and at the same time uses a government envelope in the conduct of his business." ${ }^{.15}$ One reader of Searcy County's Mountain Wave, furthermore, wrote to the editor hoping to set the record straight against those who charged that the U.S. Government was headed down a liberty-stifling path to communism, "just like Soviet Russia." "In the United States," he contended, "it is sweet,

\footnotetext{
14 "Wayne Phillips Writes an Interesting Letter," ibid., January 19, 1934.

${ }^{15}$ Mountain Wave, October 5, 1934; ibid., March 23, 1934.
} 
soft paternalism. In Soviet Russia [it is] a stern, hard unsympathetic dictatorship. There is plenty of difference."16

Though most Ozarkers evidently supported the New Deal's general idea of a "cooperative commonwealth," one that "champion[ed] both the individual and big governmentthe latter to serve the former"- - a number of backcountry folks soon felt the impact of the unevenness and limitations of many of its programs as they were implemented and administered by state and regional elites. ${ }^{17}$ Local farmers generally heralded the promise of the USDA's cornhog program, for example — which sought to improve market stability and prices by reducing the supply of pork, instituting a government purchasing program, and regulating sales by issuing permits to shippers and buyers_- but some farmers in the Arkansas Ozarks complained that corporate speculators and middle-men in Springfield, Missouri, had managed to secure most of the buying and shipping permits at the expense of cooperatives formed by local farmers in the region. These and similar complaints from other small-farm regions in America prompted the USDA program's chief to promise that he would work to correct this "preference... being shown to buyers and speculators," but the unforeseen and unintended unevenness of the federal hog program typified most other New Deal farm policies as well. ${ }^{18}$

Historians have thoroughly documented the inequalities and adverse consequences promoted by the Agricultural Adjustment Administration's cotton program on poor farmers in the South, particularly for sharecroppers and tenants. Big planters and large-scale farmers, those who needed help the least but generally exerted the most powerful political influence, received

\footnotetext{
${ }^{16}$ Ibid., December 8, 1933.

${ }^{17}$ Alan Lawson, A Commonwealth of Hope: The New Deal Response to Crisis (Baltimore: Johns Hopkins University Press, 2006), 3, 6.

18 “Over 300 Searcy County Farmers Sign Corn-Hog Contracts,” Mountain Wave, March 2, 1934;
} 
the lion's share of the benefits while the federal cotton program helped encourage the dispossession of poor farmers. ${ }^{19}$ Tenancy rates in the Ozarks remained far below those in the Delta (although farm tenancy had risen dramatically in the hills since the late nineteenth century), but many federal farm programs also increased burdens upon landless hill farmers and elevated tensions between landowners and tenants in the uplands. While many of the details went unreported, a deadly conflict ensued in October 1933, for instance, between native sharecropper Monroe Mathis and his landlord, F.M. Robinson, in Searcy County. A dispute between Robinson — who had recently settled in the Ozarks and "owned a large farm" near Zack — and Mathis a few weeks before had resulted in the sharecropper's eviction. But Mathis insisted upon returning to the farm to tend the crop that he had planted and raised since the spring and had apparently determined that he would harvest it, whether Robinson approved or not. When the landowner and the sharecropper "resumed their quarrel" over the crop, Mathis gunned down his former landlord and was subsequently arrested on murder charges. ${ }^{20}$

In general, most family-oriented farmers with small landholdings in the Ozarks wound up faring little better than tenants in the broader scheme of the administration of New Deal farm programs. In December 1933, more than 200 hill farmers met at the Searcy County Courthouse at Marshall "to discuss the benefits that are being afforded" locally by the federal government.

${ }^{19}$ One of the most in-depth accounts of the AAA's adverse effects upon poor farmers is Pete Daniel, Breaking the Land: The Transformation of Cotton, Tobacco, and Rice Cultures since 1880 (Urbana: University of Illinois Press, 1985). On AAA programs in the Arkansas Ozarks, see Blevins, Hill Folks, 112-114.

20 "Farm Owner Near Zack is Killed," Mountain Wave, October 13, 1933. It is also worth mentioning that historian Jarod Roll notes that many of the tenants who settled in the Missouri Bootheel and eastern Arkansas to farm newlydrained lands after the turn of the twentieth century migrated from the Ozarks, since "the process of corporate consolidation and monopoly power... had wrecked the lives of these migrants in the hills." Landless and dispossessed farmers in these Delta areas and their Southern Tenant Farmers' Union assembled the most notable resistance movement against capitalist agriculture and its supporting government programs during the 1930s. Jarod Roll, Spirit of Rebellion: Labor and Religion in the New Cotton South (Urbana: University of Illinois Press, 2010), quotation on 18 . 
The meeting, which had been called by the Searcy County Farmers Independent Association, erupted into "a heated discussion," according to the local paper, in which a number of rural folks expressed "considerable dissatisfaction." Contending that "the small farmer needs relief, too," the farmers appointed a three-man committee to draft a petition aimed to awaken government officials to "the needs of the common people." In it these Ozarks farmers-who hailed from a county divided about evenly between Democrats and Republicans — resolved that "we are all loyal to the relief work program of the Roosevelt administration [even though] many of us differ on the policy thereof." But they explained that "we have not been able to participate" or benefit enough from agricultural programs that mostly favored large and highly-capitalized producers and firms. With many small farmers on the verge of or already facing failure and foreclosure due to delinquent taxes and their inability to make mortgage payments, their current situation was "rendering farm life intolerable," their petition continued. This was grossly unfair, they argued, since "the town and city men are given higher wages than we ask for man, wagon, and team." Simply put, these Searcy County farmers "ask that we be permitted to share in the relief to such extent only as to enable us to maintain our families and save us from sacrificing and exhausting" the resources needed to make ends meet on small farms. ${ }^{21}$

Rhetorically, at least, New Deal agricultural officials such as Henry Wallace sympathized with small family farmers and advocated returning agricultural profits "back to the mass of people." Shortly after Roosevelt's reelection in 1936, Wallace toured parts of the rural South, including the Ozarks, where he saw first-hand the plight of small farm families. After returning, Wallace disgustedly remarked in an article he penned to the New York Times that "City people of

21 “The Small Farmer Needs Relief, Too,” Mountain Wave, December 22, 1933. 
the United States should be thoroughly ashamed" of how they had passively allowed their rural American brethren to suffer in such deplorable circumstances. ${ }^{22}$ Despite stiff resistance from Big Agriculture and political conservatives, the Roosevelt administration embarked upon greater efforts to address rural poverty during its second term. The Bankhead-Jones Farm Tenant Act of 1937 led to the creation of the Farm Securities Administration (FSA) in September of that year, which reorganized and built upon the programs of its predecessor, the Resettlement Administration. "Rural rehabilitation" became the FSA's most significant program goal, which was "centered on the concept of government loans and grants providing or returning security to small-scale and impoverished farmers." From its inception, however, the FSA "stumbled" because of the "vagueness in its goals and methods," according to historian Charles Kenneth Roberts. $^{23}$

For a handful of rural Ozarkers, assistance from the FSA helped save their farms, at least for a few more years, though it typically tried to do so by bringing them more thoroughly into the agribusiness political economy promoted by local and regional elites. By the end of 1942, Boone County farmer Oscar Conner, for instance, had become an FSA success story. In 1929, Conner and his family left their 117-acre farm on Gaither Mountain and spent four years in another state hoping to make a better living. In 1933, they returned to their Ozarks farm with little to show from their hiatus as migrant workers. Back on the farm, they struggled to scrape up a "bare existence" during the next few years. Between 1936 and 1942, the Conners received six small loans from the FSA and its predecessor, ranging from $\$ 125$ to $\$ 285$ each. By late 1942 ,

${ }^{22}$ Wallace quoted in Thompson, Spirits of Just Men, 139, 141.

${ }^{23}$ Charles Kenneth Roberts, "Client Failures and Supervised Credit in the Farm Security Administration," Agricultural History 87 (Summer 2013): 370-371. 
the Conners had succeeded in hanging on to their farm by selling calves, hogs, lambs, wool, tomatoes, and a colt and had repaid all of their FSA loans in full, including the five-percent interest owed on them. Now that the farm seemed secure, the Conners "centered" their agricultural ventures on growing chickens in a new " $14 \times 40$ house of logs and lumber" and selling poultry and eggs "on the commercial market," joining the proto-factory-farming trend that would eventually give rise to Don Tyson's Fortune 500 poultry empire. Two children remained at home, but three of their oldest sons had joined the armed services and another attended the School of the Ozarks in Branson, Missouri. The Conners, a Kansas City newspaper reported, had "rise[n] above the plane of bare existence." 24

For a majority of backcountry farmers in the Ozarks, however, small loans and grants from the FSA made little difference. Though 155 families in Izard County received federal farm loans in 1936, only 7 of them ended the year with even "sufficient supplies and food," let alone the resources to make their farms profitable. ${ }^{25}$ Though, as Roberts points out, the FSA generally maintained flexibility and leniency in collecting payments from rural debtors, some Ozarkers, nevertheless, found themselves facing court orders that required them to settle their accounts with the FSA. In April 1940, the U.S. District Court at Harrison ordered J.N. and N.E. Pangle to sell two horses and two colts at a public auction in order to make a payment on their past-due FSA loan. Similarly, the federal court at Harrison issued a "Decree of Foreclosure" against

\footnotetext{
24 “An Ozark Family Out of Debt After a Long Struggle,” Kansas City Star, December 30, 1942.

${ }^{25}$ Blevins, Hill Folks, 112.
} 
Floyd and Argie Pumphrey of Lead Hill in October 1941 to help satisfy the $\$ 392.78$ debt they owed on a loan from the old Resettlement Administration. ${ }^{26}$

The FSA, despite its sincere intentions to help alleviate rural poverty, was wrought with shortcomings, due most notably, according to Roberts, to its "vague" and conflicting policy prescriptions "which combined modern scientific farming techniques with an old-fashioned, even nostalgic, view of the family farm and the rural community." The FSA proved unwilling or unable to challenge the structure of agricultural capitalism that lay at the heart of the decline of family farms. Instead, it focused mainly on "retraining farm families in improved farm and home management" and instilling the "right mindset" and "right attitude" in its clients. Then, the FSA assumed that rural poverty could be solved with small government loans and grants that would help rescue rural families from their outdated farm practices and bring them into the prosperity promised by modern agriculture and agribusiness. Its limited impact created a large bulls-eye for Big Agriculture and conservative critics as they continued their political assaults on the program. By 1943, opponents had successfully "gutted" the FSA. ${ }^{27}$

"No matter how hard they worked," writes historian Charles Thompson Jr., small farmers in the Mountain South “couldn't make it in the farm economy structured as it was. No matter how skilled they were, no matter whether their rows of corn were straight and their grain cradle swings true, there was a lot about farming they couldn't control, particularly the price of their" products. "As the government pushed modernization, farm youths on the smallest of holdings

${ }^{26}$ U.S. v. J.N. Pangle and N.E. Pangle, Civil Action no. 20, April 1940; and U.S. v. Floyd Pumphrey and Argie Pumphrey, Civil Action no. 60, October 1941, District Court of the United States, Western District of Arkansas, Harrison Division, National Archives at Fort Worth.

${ }^{27}$ Roberts, "Client Failures and Supervised Credit," 371-374, 384-386. 
would know there was no future for them in agriculture." 28 Fingering federal bureaucrats and their "high modernism" alone for the shortcomings and failures of government assistance to small farmers, however, overlooks the fact that local and regional political leaders who were in the best positions to influence policies offered no serious attempts to help save family farms in the backcountry. No matter how much they might rail against national economic injustices and promise to bring Wall Street and Big Money to heel, most local and regional political elites generally concurred with USDA economists, whether they actually said so or not, who "believed the small farmers would ultimately need to leave their farms to improve their lives." 29

Instead, Ozarks political elites, in accordance with their New South vision, utilized their power to tap government resources for promoting industrial and agribusiness growth in the region, brimming with confidence that development would stem the tide of massive outmigration from the region and alleviate poverty by raising all boats. By the late 1930s, the region's New Deal-supporting political leaders, like most other liberal-progressives throughout America, had begun shifting their priorities away from direct relief and the regulatory reform of capitalism and toward the Keynesian pursuit of government programs aimed to assist the growth of private industry. ${ }^{30}$ This transition undoubtedly reflected, at least in part, the growing demands of some

\footnotetext{
${ }^{28}$ Thompson, Spirits of Just Men, quotations on 144 and 25, respectively.

${ }^{29}$ Quoted from ibid., 141-142.

${ }^{30}$ Historian Alan Brinkley argues that New Deal liberals between the late 1930s and the end of World War II "abandoned or greatly de-emphasized the abortive experiments in statist planning, the failed efforts to create cooperative associational arrangements, the vigorous if short-lived anti-monopoly crusades, the overt celebration of government, and the open skepticism toward capitalism and its captains." Instead, postwar liberals "praised the New Deal for having solved the problems of capitalism without altering the structure of capitalism; for having used the state to save the economy without intruding the state too far into the economy." He attributes this "reconstruction" of liberal-progressivism to "the failures and unintended consequences of some of the reform efforts of the early 1930s; [to] the impact of the recession of 1937-38, the frustrations that unexpected crisis had created, and the reassessments it had inspired; [to] the emergence of a new set of economic ideas - ultimately identified chiefly with John Maynard Keynes - that provided an alternative to the older, more institutional approaches; [to] the dramatic economic growth of the 1940s, the experience of wartime economic mobilization, the resurgence of
} 
of the region's most powerful political constituents. As early as the summer of 1934, disgruntled merchants from six Ozarks counties met in Harrison to draft a resolution "protesting Federal relief authorities against the free distribution of commodities in the drought areas of the midwest" and insisting that the "distribution of such commodities should be handled through the regular channels of business." 31 With such pressure mounting, political leaders tailored new agendas they hoped would also appeal more broadly to their distressed rural constituents as well, most of whom were desperate for any form of assistance that would somehow help their economic survival—no matter how short-term it might be. Writing in December 1933, a "hill farmer" and rural school teacher in Searcy County complained that, despite the fact that the "New Deal has done many things," it had "benefitted the small hill farmer but very little." As a solution to rural Ozarkers' immediate problems, however, he did not call for a restructuring of the agricultural political-economy but recommended, instead, an even greater increase in government funds for infrastructure projects, such as more "road improvement," to put local boys to work earning much-needed supplementary incomes that would help sustain their families and farms. ${ }^{32}$ Faced with town businessmen's growing resentment of government interference and the persistent desperation of backcountry farm families for any kind of immediate help they could get, then, infrastructure development seemed to be the most politically viable solution.

popular conservatism, and the growing fear of totalitarianism." "The new liberal outlook," Brinkley continues, "had emerged so slowly, so haltingly, in response to so many different influences that some of those who embraced it did not always recognize how much it had changed — or why." Alan Brinkley, The End of Reform: New Deal Liberalism in Recession and War (New York: Vintage Books, 1995), quotations on 265-267.

31 "Merchants of Six Counties Organize," Mountain Wave, August 31, 1934. In a similar vein, the owner of a grocery company with stores in Fayetteville and Siloam Springs wrote Governor Parnell in 1931 to complain about the "unusual lot of publicity" that had been drummed up around the country about Arkansas's drought and depressed economic conditions. In particular, he was perturbed by a hand bill that he discovered had been circulating in the town of Superior, Nebraska, that asked citizens to donate food to feed the hungry in Arkansas. "It will take our commonwealth years to live down this name we are getting from the New England and Northern states," he wrote. "Isn't there something we could do to quiet this down?" W.E. McWhorter to Harvey Parnell, February 11, 1931, box 6, folder 179, Harvey Parnell Papers, Arkansas History Commission, Little Rock.

32 “'Our Readers' Views," Mountain Wave, Dec. 15, 1933. 
Ozarks congressman Clyde T. Ellis, representing northwestern and north-central Arkansas's large Third District, led the charge to tap federal resources for massive infrastructure projects that he and his supporters promised would bring "the dawning of a new day in Arkansas"- projects that "should considerably stimulate business" and in which "thousands of people will be given work." Congressman Ellis, the son of a Benton County farm family, a former teacher and school superintendent at Garfield, and an attorney at Bentonville, worked diligently to add provisions for the construction of a series of hydroelectric dams on the White River to the 1938 Flood Control Act. Inspired by the government's Tennessee Valley Authority (TVA) in Appalachia and the extensive federal reservoir projects in the West, Ellis called for the creation of a White River Authority (WRA) to promote not only flood control but to provide public electrical power and spur industrial development in the Ozarks as well. "While the Government for years has been spending millions out West" and in Appalachia on such projects, dam supporters in Arkansas announced that "this part of the Southwest should now glory in the fact that it, too, is getting Federal money." "The far reaching potentialities of this program now at last definitely launched are so extended," they extolled, and "the benefits to come to the present and more to the future generations [are] well nigh incomprehensible." After the House of Representatives passed a federal flood control bill in June 1938, R.E. Overman, the chairman of the Arkansas State Flood Control Commission, boasted that "it may be stated, earnestly and candidly, that Arkansas today is 'sitting in the lap of the Gods.",33

\footnotetext{
33 "President Signs A Bill Carrying North Fork Dam," undated newspaper clipping from Yellville's Mountain Echo, Clyde T. Ellis Papers, Series 2, box 5, folder 35, Special Collections, University of Arkansas, Fayetteville (hereinafter cited as Ellis Papers); W.C. McClure, "The Ice is Breaking for Flood Control," public statement released on behalf of the State Flood Control Commission, June 30, 1939, Carl E. Bailey Papers, box 18, Flood Control folder, Arkansas History Commission, Little Rock (hereinafter cited as Bailey Papers); R.E. Overman, "Reservoirs for Arkansas," circular distributed by the State Flood Control Commission of Arkansas, June 6, 1938,
} 
Hardly had the ink of Roosevelt's signature dried on the Flood Control Act of 1938 before local elites excitedly proclaimed the victory of their long-held visions to transform the Ozarks. After introducing a bill to Congress in January 1939 to establish the WRA, Ellis declared that its passage "would mean the difference between poverty and prosperity" in the region. The dams, he claimed, would achieve much-needed flood control, "provide for the agricultural and industrial development of the White river valley," generate cheap electricity for "every home in my district, both rural and urban," and "provide jobs for everybody in my district who wants to work." Local supporters echoed the enthusiasm. At a public hearing convened at Harrison by the Corps of Engineers' Little Rock office in September 1940, engineer Col. Stanley L. Scott "declared that he had never attended a public hearing at which such unanimous approval of a project was voiced." According to Ellis, "more than a thousand" people "from all parts of the White River basin" attended the hearing at Harrison. ${ }^{34}$ Mrs. C.W. Gray, a former school teacher in Baxter County who now resided in Apache, Oklahoma, wrote Ellis after hearing of the prospects for federal dam construction to thank him for his hard work on behalf of the region and its people. "That part of Arkansas has always been sadly neglected, always lived on promises," she wrote. "You probably have you a life job if that Dam on Norfork is built," she guessed. But Gray strongly advised Ellis to stay on top of "push[ing] the project...to actual construction,"

Bailey Papers, box 24, Flood Control folder; "Ellis Proposes U.S. Authority for White River," Mountain View Herald, January 20, 1939; Shelia Yount, "Clyde Taylor Ellis (1908-1980)," Encyclopedia of Arkansas History and Culture (http://www.encyclopediaofarkansas.net/encyclopedia/entry-detail.aspx?entryID=2532);

${ }^{34}$ B.N. Timmons, "White River Authority Bill No Mean Measure; Magnitude Compares with Famous TVA," undated clipping from the Arkansas Democrat, Ellis Papers, box 4, folder 18; "Bill for Flood Control Along White River," Herald-Democrat (Siloam Springs), January 26, 1939; Frances Shiras, "Norfork Dam," Arkansas Historical Quarterly 4 (Summer 1945): 152; "Statement of Clyde Ellis, Member of Congress from Arkansas," statement issued to the Senate Commerce Committee, July 13, 1941, Ellis Papers, box 5, folder 34. 
because rural Ozarkers "have had so many promises that they believed nothing until its [sic] done." 35

Despite mounting efforts—or, as the White House put it, the "reactionary trend"—from political conservatives in Congress to "doom... administration plans for developments similar to TVA" in the Ozarks, President Roosevelt approved the U.S. Army Corps of Engineers' feasibility study and its recommendations for the construction of hydroelectric dams in the region in August 1940 and urged Congress to act. By the summer of 1941, however, it had still failed to pass Ellis's bill, though the Corps had begun the "first phase of the dam and reservoir" of its pilot project on the North Fork River in Baxter County in accordance with the 1938 Flood Control Act. Frustrated by Congress's feet-dragging, particularly on Ellis's provisions for the WRA and public hydroelectric power, delegations of local businessmen and other damsupporting elites from the region, including one group of "more than forty men," began making trips to Washington in the summer of 1941 to lobby Congress to pass Ellis's White River bill. One anxious Baxter County dam advocate, who was starting to lose all patience with Congress, framed the fight as a "modern version" of the battle between "David and Goliath"“Congressman Clyde Ellis vs. a Congress that hasn't thrown us anything but table scraps for the last 50 years." Urging fellow Ozarkers to step up their political activism to attain justice, he argued that "the least we can do is to chip in, buy Congressman Ellis a new sling and some ammunition." Likewise, Kansas City-native and Mountain Home resident Tom Shiras, the editor of the Baxter Bulletin and one of the region's chief spokesmen for local dam and industrial boosters, wrote Ellis in February 1941 to tell him that "we are all pretty well sunk down here

\footnotetext{
${ }^{35}$ Mrs. C.W. Gray to Clyde Ellis, July 11, 1939, Ellis Papers, box 5, folder 31.
} 
over the Northfork dam situation," because, even though "the president endorsed power for the dam when we were up there a year ago," Congress had authorized "no power yet." "If this thing goes on as is," he continued, "we will have only a frog pond instead of a lake."36

Ellis's proposal faced stiff opposition from a coalition of political conservatives in Congress, the strong lobbies of private power companies, and a small cadre of environmental conservationists. Frederick Sullens, a conservative columnist for the Daily News in Jackson, Mississippi, for instance, claimed that Ellis's proposal was “just a plan to sell power and costly electric gadgets to squatters and shanty dwellers who subsist on corn pone and sow belly."37 Democratic congressman John J. Cochran of St. Louis, Missouri, helped lead the political opposition against Ellis's "lavish program," contending at a meeting of the House Flood Control Committee in May 1941 that the Corps's dam projects and the creation of a WRA were far too costly and altogether unnecessary. Moreover, he complained that the expensive dams would inundate valuable farm land and "strike a critical blow to state conservation." The St. Louis Globe Democrat believed that Cochran was "dead right," asserting that "such a program would be additional encroachment of national government upon private industry," and called on Americans to help "arrest this federal invasion of Missouri and Arkansas by a little TVA." The Missouri Conservation Federation also drafted a resolution against Ellis's proposed dams in the Ozarks at its convention in Kansas City, claiming that their construction would result in "a

\footnotetext{
36 "Program for Little TVA's Said to be Doomed," Arkansas Gazette, June 17, 1939; "President Roosevelt Approves the White River Project," Daily Echo (Eureka Springs), August 19, 1940; "White River Development to be Urged," unknown newspaper clipping, August 30, 1940, Ellis Papers, box 4, folder 19; John Q. Adams, "Local Citizens Enjoy Visit in Washington, D.C.," undated newspaper clipping from Mountain Echo (Yellville), Ellis Papers, box 4, folder 17; T.S., "Anthology," undated newspaper clipping for the Baxter Bulletin, Ellis Papers, box 4, folder 18; Tom Shiras to Clyde Ellis, February 11, 1941, Ellis Papers, box 5, folder 32.

${ }^{37}$ E.W.P., "Ediscope," unknown and undated newspaper clipping, Ellis Papers, box 4, folder 19. Ozarks resident "E.W.P." took grave offense at Sullens's comments, retorting that his "ignorance is colossal" and responding with a lengthy rebuttal to show that "Ozarkians" were more "progressive" than the "swamp angels" of Mississippi in almost every statistical category.
} 
needless, shameful spoliation of nature." Ellis responded directly to the Missouri Conservation Federation's attacks, alleging that this "so-called” environmental organization was not really "what it professes to be" but rather "an organ of the already repudiated Missouri power-trust and speaks the voice only of that gang."38

The most powerful political obstacle, as it turned out, proved to be the private utility companies. Once their fears of competition from public utilities were at least partially allayedfor the time being, that is -Ellis's proposed hydroelectric dam projects moved forward. The privately-owned Arkansas Power and Light (AP\&L) company, which held a monopoly on the electric power utilities that were available in the state in the 1930s and early 1940s, temporarily backed off of its once "unremittingly hostile" position against federal hydroelectric dams when it realized it could "purchas[e] power at beneficial rates from federal facilities" rather "than sinking [its own] investment capital into large-scale dam construction." It had, after all, already reached an agreement with the TVA to profitably import power to Arkansas from government facilities in Memphis. AP\&L managed to become the main power distributor of the Norfork and Bull Shoals dams after their completion, but it did resent and work to obstruct the formation of the Arkansas Electric Cooperative Corporation in 1949 and new publicly-owned utilities' use of later dams constructed by the Corps in the 1950s and 1960s. ${ }^{39}$

When Ellis dropped his proposal for a government-managed WRA in 1941, his agenda for the construction of a series of dams in the Ozarks - a list that would grow longer and longer

\footnotetext{
38 "Cochran Carries the Fight," St. Louis Globe-Democrat, May 11, 1941. For further treatment of Missouri conservationists' early opposition to other federal dam projects, see Leland Payton and Crystal Payton, Damming the Osage: The Conflicted Story of Lake of the Ozarks and the Truman Reservoir (Springfield, MO: Lens \& Pen Press, 2012), 168-173.

39 Johnson, Arkansas in Modern America, 73.
} 
over the next few years to include almost every free-flowing river in the region—finally received authorization and appropriations from Congress. Ellis's proposal for a "little TVA" and government planning in the region, after all, had never been his main priority anyway. Not long after submitting his White River bill to Congress in 1939, Ellis candidly admitted to a St. Louis attorney who had written him to inquire about his proposal that "the WRA was introduced by me upon the suggestion of the anti-power trust leaders here. If we can get the dams without having an authority, it will not be necessary to go ahead with it." ${ }^{, 0}$ The TVA model had merely been a political means by which to secure federal approval and funds for hydroelectric dams and large reservoirs for the regional economic development and jobs that his constituents clamored for. Ellis's provision for hydroelectric power finally passed the Senate as part of a new flood control bill, and Roosevelt signed it into law on August 22, $1941{ }^{41}$

In petitioning the Senate before it finally passed his measure for hydroelectric dams in the Ozarks in July 1941, Congressman Ellis had argued that all of the opposition to his bill came from selfish interests outside the region. "In my district," he declared, "there is not a single person opposed to these projects that I know of." ${ }^{42}$ Despite solid evidence indicating a groundswell of support for the dams in the region, it seems that Ellis had to stretch, to say the least, to claim absolute unanimity among his constituents. Support certainly outweighed opposition, but at least some rural Ozarkers remained suspicious, particularly some backcountry farmers who were trying to remain anchored amid the waves of farm failures and outmigration from their small communities. Their vastly outnumbered voices failed to make it into the

\footnotetext{
${ }^{40}$ Clyde T. Ellis to Arthur T. Brewster, June 16, 1939, Ellis Papers, box 5, folder 31.

${ }^{41}$ Shiras, "Norfork Dam," 152.

42 "Statement of Clyde Ellis, Member of Congress from Arkansas."
} 
region's booster-dominated press, but the discourse of dam-supporting newspapers suggested that some important "persuasion" still remained to be done locally. In March 1940, Tom Shiras's Baxter Bulletin attempted to convince its most skeptical readers that everyone, rural and town folks alike, would benefit greatly from the construction of the Norfork Dam and reservoir. Not only would families find much-needed work on its various construction projects, but the county's overall population was expected to swell by "several thousand people" during the building of the dam and lake alone to create whole new market opportunities, not to mention what was sure to come after the projects were completed. "Many of the men will be employed on the dam and will have no time for gardening or raising chickens and will buy most of what they and their families eat," the paper explained. "This will open a new market for vegetables and all kinds of produce for our farmers if they take advantage of it...Vegetables, fruits, chickens, eggs, butter, whole milk and cream, home cured hams and bacon and everything else," it continued. "Those farmers who get set for this new market will no doubt make money from it. ${ }^{43}$

The Baxter Bulletin continued its efforts to "sell" the dams' promise for prosperity to uncertain locals in July 1941. "Some see a dark side, others a bright," it acknowledged, indicating at least some degree of skepticism in the region, "and we cling to the latter." Arguing that the "precedent" of the construction of Powersite Dam and Lake Taneycomo in the Missouri Ozarks in the 1910s and that area's subsequent economic development ensured that "the same thing will happen in Baxter County when Norfork lake is created," the paper called for all of the region's economic sectors to work in unison for the sake of progress. "Looking into Baxter

\footnotetext{
43 “'Opportunity for Baxter County Farmers," Baxter Bulletin, March 8, 1940.
} 
County's future," the Bulletin envisioned that tourism, manufacturing, mineral resources development, and agriculture would all work together to promote regional economic growth for everyone. "The opportunity to make this county one of the best in the state is here. It rests with our citizens as to what they will make of it." In the same issue, the Bulletin implored those who it considered to be self-serving and hard-headed political leaders in other regions of Arkansas to open their eyes to the region's potential and support more liberal state funding for highway improvements to help complement the federally-initiated "progress" in the central Ozarks and assist economic growth that would benefit the whole state. ${ }^{44}$

The local economic boom that accompanied the Corps of Engineers's ground-breaking and launching of construction projects on the Norfork Dam proved convincing enough for most rural folks in the region. By the third week of March 1941, as the Corps prepared its initial stages of the project, the Baxter Bulletin reported that "hundreds rush here in hope of getting work," despite the fact that "it will be at least 30 to 60 days before there will be any work opportunities available on the dam." Though desperate rural workers eagerly awaited the construction projects on the dam itself to begin, ancillary projects such as clearing, grading, graveling, road and railroad building and rerouting, the construction of workers' camps and living quarters and managerial and government offices, the clearing of right-of-ways and erection of power lines by AP\&L, and work by private developers on future town sites were already well underway by April. Even before the dam itself began to go up, Marion County's Mountain Echo marveled at how "the area around the Northfork dam site, which a few weeks

\footnotetext{
44 “Looking into Baxter County’s Future," ibid., July 11, 1941.
} 
ago was a stretch of rough, primitive Ozark mountain wilderness, is developing fast into a modern industrial picture." 45

The jobs created by the construction of Norfork Dam provided timely and much-needed opportunities for desperate rural folks in the area. Letters poured into Congressman Ellis's and other political leaders' offices from constituents requesting assistance in getting work on the federal project. Cecil Keiter of Searcy County asked Ellis to help him get a job on the Norfork Dam working as "a Tool checker or Tool Room Man," though he certainly "would take a Watchmans job" if others were not available. "I own 40 acres of Land and pay taxes...went over to France [during the First World] War... and also [am] a Christian man and my family needs my help badly," Keiter explained. Similarly, Marvin Morgan of Marion County informed Ellis that "I need work and shall appreciate anything you can do to get me a job. I have a family to support and it seems there is no work to be done."46

Local elites, of course, also petitioned Ellis and other officials for help to obtain certain benefits from the federal project. Ben Dearmore, a Mountain Home real estate agent and one of the most outspoken proponents of the dam projects, for instance, requested that Ellis do what he could to help him secure the Corps's government contract to conduct the land and property appraisals for the acquisitions area. John Q. Adams, the superintendent of Yellville-Summit High School in Marion County, also asked Ellis to use his influence to help his nephew and

\footnotetext{
45 "'Hundreds Rush Here in Hope of Getting Work Before Norfork Job Opens," ibid., March 21, 1941; "Wilderness Becomes Industrial Scene at the Norfork Dam Site," Mountain Echo, April 2, 1941.

${ }^{46}$ Cecil E. Keiter to Clyde Ellis, June 14, 1939 and Marvin Morgan to Clyde Ellis, October 26, 1939, Ellis Papers, box 5 , folder 31 .
} 
"some of our boys to get jobs as truck drivers" on the federal construction project. ${ }^{47}$ Though Ellis explained that many of these types of decisions would ultimately be up to Corps bureaucrats, District Engineer S.L. Scott of the Little Rock office assured Ellis that "wherever it is possible under the regulations to hire a man in whom you are interested, I shall be glad to do so, provided, of course, that he has the necessary qualifications to perform the work to which he may be assigned." ${ }^{48}$ Like most other government projects in the past, federal officials agreed to delegate most of the decisions on the ground to local officials and elites.

Despite the Corps's and other government agencies' deference to the local political structure, area elites encountered some challenges to their control that their plans had not foreseen. The Corps and its private contractors agreed to grant top priority to hiring local residents on construction crews, but after sifting through hundreds of applications and soliciting suggestions from Congressman Ellis they failed to find enough locals who were qualified for some of the more skilled and best-paying jobs. Concerned that the Corps and its contractors might start importing outside laborers to fill these jobs and others and, thus, that many of the dam project's payroll checks would wind up being spent elsewhere to the detriment of local businessmen, Rex Bodenhammer, one of Tom Shiras's business partners in Mountain Home, asked Ellis to attempt to persuade Corps officials and its contractors to loosen the hiring qualifications, since "anyone who has been or had experience as a mechanic" or "a background of work in mines" could "easily" do the work. ${ }^{49}$

\footnotetext{
${ }^{47}$ Ben Dearmore to Clyde Ellis, June 13, 1939 and John Q. Adams to Clyde Ellis, August 31, 1939, Ellis Papers, box 5 , folder 31 .

${ }^{48}$ S.L. Scott to Clyde Ellis, July 25, 1939, Ellis Papers, box 5, folder 31.

${ }^{49}$ Clyde Ellis to Ralph Rea, October 24, 1939 and Rex Bodenhammer to Clyde Ellis, October 26, 1939, Ellis Papers, box 5 , folder 31 .
} 
At least some intra-regional conflict also surfaced over which towns and locales would receive the most benefits from the jobs and economic boom created by the dam's construction. In February 1941, County Judge Earl Berry of Yellville complained that "an injustice is being done to the people of his county," because the Corps deliberately favored Baxter County in its hiring "method." This put Ellis, who explained that Berry "is one of our best friends in this fight and who was my campaign manager two years ago," in a rather uncomfortable predicament. So the congressman wasted no time in requesting that the Corps's district engineer at Little Rock "give the matter your attention and see if an adjustment can be made."

One of the greatest concerns among local elites and political leaders arose when representatives of the Brotherhood of Carpenters, an affiliate of the American Federation of Labor, and other labor unions arrived in March 1941 to begin organizing construction workers on the Norfork project. The Baxter Bulletin and local elites strongly objected, insisting that "the sentiment in this section is for an open shop, and that the unemployed men in Baxter and adjoining counties build the dam." The Bulletin speculated that "if the job was unionized local men would be shoved off the job and that a labor racket...would be inaugurated." Mountain Home mayor and automobile dealership owner Hugh Hackler quickly convened "an impromptu meeting...to discuss the situation" with other local officials, area businessmen, and the union representatives. Hackler vowed "that any attempt to bring in outside labor that would conflict with local labor would be resisted and that any racket would be immediately protested." The union representatives assured Hackler and other area elites that they had no intention to steal jobs

${ }^{50}$ Clyde Ellis to T.F. Kern, February 6, 1941, Ellis Papers, box 5, folder 32. 
from locals and would continue prioritizing the employment of area residents, but the alarmist discourse over organized labor at the dam persisted, nevertheless. ${ }^{51}$

Local elites petitioned Congressman Ellis to intervene, so Ellis called on the Arkansas Department of Labor to open an investigation of the unions' activities at the Norfork Dam in June 1941. But Director Eli W. Collins replied that his office had "no definite information upon which to base an investigation." With collective bargaining rights protected by the National Labor Relations Act of 1935, little could be done to halt organized labor at the dam. Collins assured Ellis, nevertheless, that he had "instructed one of our most reliable office managers to make a general checkup during a visit to the dam site on June 13.” The inspector reported back after his trip to Norfork, however, that "Baxter County folks are getting most of the jobs on that project" and that the labor unions, as far as he could tell, were otherwise conducting their affairs in a lawful manner. Not quite sure what he thought Ellis expected his office to do now, Collins continued: "As I wrote you previously, if you will give me definite information as to what your friends deem to be wrong we will make a serious effort to straighten the situation out." ${ }^{52}$

To the chagrin of many local elites and officials, the Corps's main contractors, the Utah Construction Company and the Morrison-Knudsen Company, signed an employment agreement for common labor with the American Federation of Labor's Building and Trades Council on June 11, 1941. They also signed contracts with the Union of Electrical Workers and the Brotherhood of Carpenters for skilled "branches" of labor. ${ }^{53}$ The Arkansas Gazette reported on June 22 that it appeared that "the project has been turned into a card job," due to the organized

\footnotetext{
51 "Labor Union Attempting to Organize Skilled Workers on Norfork Dam Project," Baxter Bulletin, March 26, 1941.

${ }_{52}$ Eli W. Collins to Clyde Ellis, Ellis Papers, box 5, folder 34.

53 “A.F. of L. Agreement for Workers at Dam," Harrison Daily, June 13, 1941.
} 
labor agreements, though it acknowledged that a small wage increase for workers had gone into effect, that "seventy-five per cent of the labor being used is from Baxter and adjoining counties," and that "the pay roll gradually is increasing" from the nine-hundred men already employed. ${ }^{54}$ The Baxter Bulletin maintained that the "sentiment over the entire county had been strong against organization of the job because people here feared that it would result in a 'racket' such as reported on other large construction jobs.” Though the greatest tensions on the ground, it admitted, seemed to have "to a large extent died out" during the weeks following the labor agreements, the paper suggested that "some laborers still maintain that the Unions are doing little except collecting dues while others seem well satisfied. ${ }^{.55}$

According to the Baxter Bulletin, the simmering controversy that it claimed still lingered in the area over organized labor at the dam appeared to have ignited a violent incident at the Norfork Dam site in August 1941. Under the cover of darkness during the wee hours one Friday morning, some unknown vigilantes exploded dynamite under the floor of the Building and Trades Council office, shattering all of the windows and destroying much of the floor. The explosion also broke out several windows and damaged some plumbing in the state employment office building next door and inflicted some collateral damage on a nearby café. Investigating officers "found no clues" to determine who was responsible, the paper reported. Though union representative M.S. Lee claimed "that he knew of no reason for the blast," the Bulletin speculated that tensions between the union and resentful workers had probably caused the drama. "A persistent rumor" that the union "planned to hire labor other than men in this county" may

\footnotetext{
54 “900 Men at Work on Norfork Dam,” Arkansas Gazette, June 22, 1941.

55 "Dynamite Wrecks Office of Building and Trades Council at Norfork Dam Friday," Baxter Bulletin, August 22, 1941.
} 
have led to the incident, the paper suggested, though it admitted that this theory "could not be verified." "Another speculation" posited by the Mountain Home paper held that new workers' resentment toward the expiration of the union's 30-day "special" on "initiation" fees may have prompted the incident, since those who joined after August 1 saw their membership dues rise from $\$ 5$ to the regular $\$ 10.35$. But the union versus laborer conflict at Norfork, the Bulletin surmised, did not end with the destructive blast at the union office. "Witnesses" stated that a “street fight" between Carpenters Union representative John Mullins and two "workers," Ray Amyx and Burnice Martin, broke out following the dynamite incident several hours later on Friday evening. Blows from Amyx and Martin "knocked down" Mullins "several times" before the two aggressors "submitted" to local officers and received small fines from the local justice of the peace for assault. ${ }^{56}$

The voices of rural workers themselves regarding organized labor at the dam are absent from the historical record. The Baxter Bulletin undoubtedly exaggerated in claiming that local workers "over the entire county" were "strong[ly] against organization of the job." After all, as historian Michael Pierce points out, pro-union "labor and anticorporate radicalism was endemic in hills and valleys of northwestern Arkansas" during the first half of the twentieth century. As Ozarkers attempted to navigate the devastating depression of the 1930s and early 1940s that only stacked greater burdens upon their long-time struggles for sustainability in the rural backcountry, however, local elites' warnings that organized labor would create corrupt and self-serving

\footnotetext{
${ }^{56}$ Ibid. Before securing work on the Norfork project, the 39-year-old Amyx was a road construction contractor in West Plains, Missouri. It is unknown whether he was a small contractor or manager on the Norfork project or an ordinary "worker," as the Bulletin suggested. The 30-year-old Martin had been a local farm laborer in Baxter County and was likely a common laborer at Norfork. Manuscript Census Returns, Sixteenth Census of the United States, 1940, Population Schedules, City of West Plains, Howell County, MO, and Greenwood Township, Baxter County, AR.
} 
"rackets" to steal much-needed jobs from desperate locals likely sounded an especially worrisome alarm among many area residents. Like Governor Orval Faubus, Sam Walton, and Don Tyson would do in the region during subsequent decades, anti-union local elites in Baxter and surrounding counties portrayed themselves as populist "defender[s] of Arkansas's white working class, protecting it from a labor movement dominated by outsiders and intent on undermining traditional values." In 1943 and 1944, the Arkansas legislature, under pressure from conservative lobbies such as the Christian American Association and the Arkansas Free Enterprise Association, passed an "anti-labor violence" bill and proposed the nation's first "right-to-work" law, barring closed-shop agreements in the state. Arkansas voters approved the "right-to-work" initiative 105,300 to 87,652 at the polls in the fall of $1944 .^{57}$

Though much of the opposition to Arkansas's "right-to-work" law came from citizens in the uplands, even some of the most dedicated pro-labor advocates in the Ozarks seemed torn and confused over the debate about unionization. Robert Blecker, a Baxter County resident and a worker on the Bull Shoals Dam project, wrote to Governor Sid McMath in January 1949 to voice "the side of the laboring man." Blecker explained that he had previously held "complete confidence in the Taft-Hartley Law," the congressional legislation passed in 1947 over President Truman's veto that significantly revised the National Labor Relations Act of 1935 and struck a major blow to organized labor by granting federal deference to state "right-to-work" laws like the one in Arkansas. Since its passage, however, Blecker had "been told by un-reliable sources that there is a provision in the Law that says State Laws will supersede it," and now it seemed

\footnotetext{
${ }^{57}$ Michael Pierce, "Orval Faubus and the Rise of Anti-Labor Populism in Northwestern Arkansas," in The Right and Labor in America: Politics, Ideology, and Imagination, edited by Nelson Lichtenstein and Elizabeth Tandy Shermer (Philadelphia: University of Pennsylvania Press, 2012), quotations on 99; Michael Pierce, "Labor Movement," Encyclopedia of Arkansas History and Culture (http://www.encyclopediaofarkansas.net/encyclopedia/entrydetail.aspx?entryID=4235), accessed December 11, 2013.
} 
that they were right. While earlier concerns had focused on the threat that labor unions might harm local employment opportunities, now it was "this company, The Ozark Dam Constructors, [that] is importing workers to take the jobs which we are trying to stay out on in order to get some sort of recognition," he explained. "We were told that it would take a strike to start the [National Labor Relations Board] on the job of settling the case, but now it seems that not much can be accomplished even by them because of our Arkansas Labor Laws." Wondering whether McMath had "considered the plight of Labor under these present labor laws," Blecker urged the "progressive" governor to prioritize "build[ing] Arkansas first!",58

Blecker's confusion over the unionized labor debate illustrates the broader efforts made by pragmatic hill folks to decide how new political and economic developments might best benefit their struggling families in the rural Ozarks. With little assistance from government to help them sustain their families' livelihoods with full-time smallholder farming, most rural Ozarkers came to support the federal dam projects - much like they had the Works Progress Administration, the Civilian Conservation Corps, and other New Deal relief programs-because the temporary construction jobs they created provided timely sources of income they desperately needed. Many Ozarkers undoubtedly also hoped that the dams, once they were finished, would spawn the plethora of economic opportunities that local boosters had long promised and that affordable rural electrification might make their small farms more profitable. In a substantial show of support, about 10,000 Ozarkers gathered to celebrate the beginnings of the Norfork project — "the fulfillment of their dream," as Tom Shiras interpreted it—on May 22, 1941 and to watch construction crews dynamite the majestic bluff that would help hold the massive concrete

\footnotetext{
${ }^{58}$ Robert R. Blecker to Sid McMath, January 31, 1949, Sidney McMath Papers, series I, box I, folder 3.2, Arkansas History Commission, Little Rock.
} 
dam in place. After the blast, Shiras recalled that the lyrics of "America" echoed proudly through the hills and hollers, "sung by the voices of 10,000 and accompanied by four bands."59

Only a handful of disgruntled rural folks who stood to lose their farms to the government's eminent domain for the construction of the Corps's dams and lakes remained standing in this particular battle to carry the old torch of populist backcountry resistance against this new New South agenda. In doing so, ironically, their protests joined those of a small group of conservatives and established business interests in the state and region who dreaded the changes and loss of private property that the Corps's dam projects entailed. On October 1, 1944, the more conservative of Little Rock's two major newspapers, the Arkansas Democrat, ran an article opposing the plans for future dam construction on the White River at Wolf Bayou between Guion and Batesville, which was expected to cover 40,800 acres, primarily in Izard and Stone counties. "Not only would the fertile White River Valley, [the] chief agricultural source for the two counties and one of the most scenic areas in the South, be obliterated," the Democrat pointed out, "but also one of the best timber areas in this section would be covered with water." In addition to the detriment that would be inflicted on regional timber concerns, the proposed dam "probably would do away with" area mining industries such as the Guion Silica Company. Finally, several established towns "would be wholly or partly submerged," it noted, and the "present route of the Missouri Pacific Railroad" would have to be "realigned," creating major burdens for even those established towns, businessmen, and property holders outside the Corps's acquisition area. ${ }^{60}$

\footnotetext{
${ }^{59}$ Shiras, "Norfork Dam," 155.

60 "Proposed White River Dam Would Ruin Fertile Farm Region, Wipe Out Five Towns," Arkansas Democrat, October 1, 1944.
} 
Some rural populist opponents voiced similar concerns against the government's dam construction. Reverend John Zachary of rural Johnson County wrote Governor Ben Laney in May 1945 to protest the Corps's plans for flood control projects along the Arkansas River. Zachary claimed that these projects would "cause Millions of dollars [in] Property Loss," not to mention the fact that they would destroy two of his home area's most important highways and force the railroad to reroute its tracks. Most importantly, the government's land confiscation would "plac[e] a number of good farmers on the unemployment list" in Pope, Johnson, and Franklin counties. In Johnson County, furthermore, the Corps's plans would ruin "some of the finest orchards" in the region. "I ask as a minister of the Gospel trying to hold our people in Peace and good will...that you Protect our state from this great Loss," Zachary pleaded with the governor. Laney wrote back to the rural Johnson County preacher to assure him that he was "aware of the many conflicting interests concerned" but also to advise him that "that the people in the affected territories will be the ones who will determine whether or not this engineering project is accepted or rejected." As for the governor's own position, Laney told Zachary that populist democracy would decide the issue: "I have determined that the will of the people shall prevail" and that "the people themselves can determine what is best."

A number of backcountry folks who stood to have their lives and a lifetime of work uprooted by the dam projects also protested. One elderly farmer's wife from Pope County, Mrs. George W. Scott, wrote to the governor's office to request help in saving her family's farm from condemnation by the Corps. "This [farm] is all we have for a life time of work and we aren't young people any more and don't want to have to start all over again at our age," she explained.

\footnotetext{
${ }^{61}$ John Zachary to Ben Laney, May 4, 1945 and Ben Laney to John Zachary, May 7, 1945, Ben Laney Papers, box 3, folder 53-1, Arkansas History Commission, Little Rock.
} 
"They are trying to take our land and push us out because we are the poores [sic] and less educatid [sic] and don't know what we can do." "So I am beging [sic] you please if there is nothing you can do to help us let us know whom we can find out from [because] we don't want to loose [sic] our place and have to move and start again," Scott concluded. ${ }^{62}$

In another letter of protest in March 1941, Baxter County farmer J.M Gasset wrote Congressman Ellis urging him to consider the detrimental effects of a depreciating tax base on local residents that the construction of Norfork Dam posed to the area. Gasset stood to lose 55 of his 160 acres to the government for the project, and, aside from his likely resentment over losing a significant portion of his farm, he "want[ed] to know when this Dam is completed and the Good...land is tuck [sic] out of Taxashen [sic] what will be the Results in taxes in Baxter County[?]" "Will it Rase [sic] the Revenue of the Land to Equal the Present taxes or not [?]" he asked. According to Gasset's figuring, "it look[s] very much like the taxes will be about 4 times more after than now... and that will mean a lot to us Hill Farmers."63 Ellis's response to Gasset acknowledged that "in the readjustment that must come with such a big development as this there will be many headaches just as there have been many headaches in every step of progress that has been made in our country up to now." "If our forefathers had been unwilling to endure those headaches," Ellis reminded his backcountry constituent, "we would have been as backward as Old Mexico." Nevertheless, the congressman assured Gasset that "all the figures show plainly that the over-all benefits from this dam will far outweigh the various costs.” Ellis continued:

\footnotetext{
${ }^{62}$ Mrs. Geo. W. Scott to Orval Faubus, November 9, 1964, Orval Faubus Papers, box 466, folder 12, University of Arkansas Special Collections, Fayetteville.

${ }^{63}$ J.M. Gasset to Clyde Ellis, March 31, 1941, Ellis Papers, box 5, folder 32.
} 
What actually will happen is that you will have a new economy in Baxter County. It will be a new day. There will be work for farmers and farm boys to help round out there [sic] income. There will be better markets and better roads and better living conditions and people will be better able to pay taxes. There will be more property to tax and it will not be necessary to raise taxes anywhere but on the other hand taxes are paid for the benefit of the people and more taxes will mean more benefits. ${ }^{64}$

Moreover, Ellis encouraged Gasset to view his situation as a glass half-full instead of half-empty. "I think you are very lucky to have a farm that will be partly covered by the lake for you will have considerable acreage along the water's edge," the congressman explained. "It is a good guess that the 105 acres which you have left will be salable for more than the entire 160 acres which you had originally." Should he consider putting his property on the market, Ellis told Gasset that he would gladly refer him "to several people who are interested in land bordering the lake." The congressman then sent him some Arkansas real estate bulletins in case he decided to sell the remainder of his farm and purchase property elsewhere. ${ }^{65}$

After reading Ellis's reply, Gasset's outlook appears to have changed remarkably. Gasset wrote the congressman again a few months later to thank him for the real-estate bulletins, explaining that he could "get a lot of Real Good From this as I can lurn [sic] a lot about How to take the advantage of a lot of things by this." So grateful was Gasset, in fact, that he urged Ellis to run for a U.S. Senate seat in the next election, assuring him that "you Will Go Over big in My

\footnotetext{
${ }^{64}$ Clyde Ellis to J.M. Gasset, April 5, 1941, Ellis Papers, box 5, folder 32.

${ }^{65}$ Ibid.
} 
Part of the country." With this transformation in sentiments, Gasset even asked Ellis to help some of his neighbors turn their disadvantages to advantages. In particular, one of Gasset's impoverished neighbors, who lived on forty acres about a quarter of a mile from the dam, asked him to write Ellis to see if the congressman could also help him find a buyer for his farm. Gasset explained that this destitute neighbor was especially desperate to sell his place because he had "a Wife that needs to Go to a Hospital For Treatment" and could not afford the costs. ${ }^{66}$

While Ellis apparently managed to calm Gasset and some of his rural neighbors and convert them into dam supporters, at least some Ozarkers remained unsatisfied with such assurances of "progress" and a "new economy" for all, believing that the benefits promised could not offset the life-changing sacrifices they and their families were being forced to endure. In the Norfork project, the government removed about four hundred residents in the vicinity of Henderson alone to take possession of land needed for the reservoir, and local officials held a public auction to sell the "school building, houses, fence wire, roofing and everything of value" in the "one-time cotton-gin town" and small trading center. In addition to the many farms, homes, schoolhouses, and church buildings lost to the government's exercise of eminent domain in small rural communities that lay within the reservoir's flood zone, the Corps contracted a Hanover, Indiana, company to disinter and relocate a total of 1,848 graves in twenty-six

\footnotetext{
${ }^{66}$ J.M. Gasset to Clyde Ellis, February 2, 1942, Ellis Papers, box 5, folder 33. Ellis did run for the U.S. Senate but lost to incumbent John McClellan. After he left Congress in 1943, he became the first general manager of the National Rural Electric Cooperative Association, the newly-formed lobbying group that promoted the interests of the New Deal's rural electrification programs. Ellis held this position until he retired in 1967, in the meantime earning a national reputation as "Mr. Rural Electrification." Sheila Yount, "Clyde Taylor Ellis (1908-1980)."
} 
cemeteries ${ }^{67}$ Clearly, a number of rural families suddenly found their small communities, their heritage, and their entire lives uprooted.

The Corps took steps it hoped would help minimize hardships on the populations affected by its dam projects. In an effort to reduce excessive real-estate speculation and private profiteering at local residents' expense, the Corps tried to keep a relatively tight lid on the official surveys and plats that charted the lands scheduled for condemnation for the reservoir project as long as possible. Consequently, however, the government's policy for land acquisitions frequently allowed landowners as little as thirty days to vacate the premises, leaving a number of rural folks' whole lives hanging in question with little time to plan what they would do next. Shortly after the government made its early announcements about the future construction of Norfork Dam, some farmers began writing letters to political leaders to inquire about how they and their farms might be affected. Anticipating that a future lake might inundate his Baxter County farm, G.H. Hand wrote Ellis in May 1939 demanding "to know what the prospects are at once so I would know what to do about other arrangements." Though the congressman assured his anxious constituent that "it will be some time before land very far from the dam will be flooded," Ellis attempted to deflect the problem onto Corps bureaucrats, telling Hand that "Your guess as to how long it would be [before they issued condemnation notices] is perhaps as good as mine. ${ }^{\prime 68}$

Farmer R.E. Rand of the Rodney community expressed similar concerns. The location of Rand's 442-acre hill farm left no doubt that the government would soon take more than half of

\footnotetext{
${ }^{67}$ Shiras, "Norfork Dam," 156.

${ }^{68}$ G.H. Hand to Clyde Ellis, May 22, 1939, and Clyde Ellis to G,H, Hand, June 1, 1939, Ellis Papers, box 5, folder 31.
} 
his land for the reservoir, so he had already begun looking to buy a new farm and relocate.

Writing in July 1941, Rand asked Ellis to find out what the government would be paying him for his land so that he could start making arrangements to purchase another farm elsewhere, especially since "land values seem to be going higher all the time." The Corp's district engineer concurred with Rand's speculation that "it appears that a portion of your land will be needed," but he wrote that "I regret to advise you that we are not yet in a position to furnish you with a plat...or negotiate with you for its sale to the United States." Though he patiently insisted that "I don't want to pester you so much about my place," Rand wrote to Ellis again in November 1941 to explain that he was "not able to buy a farm and pay cash for it and don't want to pay inerest [sic] on one very long." Thus, he needed to know "about when they [the government] would pay for this one [so] I would know what to do" about future plans. In the meantime, Rand said he and his neighbors also needed the government to notify them about whether or not "we get another crop after this one" before they had to move, so they could begin making preparations for the spring planting season. Ellis forwarded the letter to the Corps's Little Rock office, and Maj. J.R. Crume Jr. replied to Rand that the government was "still not in a position to negotiate with you." However, though he made no definite promises, Crume advised Rand to proceed with plans "to cultivate and use your land" the following year, since his farm's "relatively high elevation" meant that "its possession by the United States will not be necessary before next fall." "Therefore, it is believed that you will be able to harvest your 1942 crops without difficulty."

Changes made by the Corps from its initial surveys of acquisition areas and first rounds of land condemnation compounded rural residents' uncertainty and hardships. After officials

\footnotetext{
${ }^{69}$ H.E. Rand to Clyde Ellis, July 13, 1941; T.F. Kern to H.E. Rand, August 13, 1941; H.E. Rand to Clyde Ellis, November 5, 1941; J.R. Crume Jr. to H.E. Rand, November 18, 1941, Ellis Papers, box 5, folders 32 and 34.
} 
realized and acknowledged that they might possess more land than they would need in some areas and still had not obtained enough in others, former Baxter County Judge R.M. Ruthven and other local boosters sought to capitalize on the Corps's excess land holdings and lobbied Ellis to pressure the government to turn over "all lands not needed for the reservoir" for private sale as soon as possible, believing that the ensuing real-estate frenzy would create "a financial boom to Baxter County." While District Engineer Maj. T.F. Kern noted that the "importance of Judge Ruthven's suggestion is appreciated," he ultimately decided that, despite the probable disappointment of many local developers, "it does not appear advisable to release any of the lands now," because the Corps might later discover that it needed some of them after all. ${ }^{70}$ But ambiguous acquisition schemes meant much more than simply the loss of potential development profits for a number of rural folks who suddenly received notice that the government planned to take their farms.

R.S. Hensley's sudden discovery that the Norfork project would turn his life upside down is a case in point. Hensley had moved to the Gamaliel community during the 1930s and settled on a small piece of land that was still in the public domain, where he claimed he had made about $\$ 300$ worth of improvements to the land, including "a nice orchard...and some fencing." While securing the legal title to the land had not seemed so urgent before, the land buzz aroused by the Norfork Dam project apparently prodded Hensley to file a formal homestead claim in February 1942. He had heard that the reservoir would inundate only a small corner of the general area where his farm was located, according to "the way they [the Corps] have it sayrvaied [sic] out

\footnotetext{
${ }^{70}$ T.F. Kern to Clyde Ellis, March 6, 1941, Ellis Papers, box 5, folder 32. As late as November 1942, furthermore, Acting District Engineer Maj. G.R. Schneider wrote Ellis to explain that "the original Government survey is greatly in error" and inform him that the Corps had had to file another petition of condemnation in federal court to acquire more lands that were needed. G.R. Schneider to Clyde Ellis, November 25, 1942, Ellis Papers, box 5, folder 32.
} 
and of corse [sic] will not no way interfear [sic] with me." The federal government rejected Hensley's homestead claim, however, and explained that it had already transferred the land he had squatted on to the Corps. A desperate Hensley asked Ellis to intervene to "get it where I could Home stead it." Though he said he was "terribly sorry to learn" of Hensley's predicament, the congressman referred him to the Corp's Little Rock office and regretted to tell him that "I just don't know whether there is anything at all you can do about it.",11

The construction of the dams and reservoirs also placed unforeseen burdens on some rural folks who remained on their backcountry farms after the Corps finished its condemnations. The government did not condemn George Bell's farm for the Norfork project, which was located about four miles from the reservoir. But Bell complained that the construction of the lake promised to isolate and make inaccessible his and other backcountry farm communities more than ever by inundating and dividing important parts of the area. Deploring the area's poor and inadequate country schools and the lack of decent roads, Bell claimed that his rural community of Elizabeth "mite have had" better educational opportunities and roads "by now if it had not been in the Reservoir." Though he was no fan of the government's dam project, Bell explained that he had " 5 children that needs a better chance at school than they have" and, since the reservoir promised to divide and ruin his rural community, he wished now that the Corps would go ahead and take his land too so he would have some money to move his family elsewhere. The Corps informed Bell, however, that it was "not in a position to negotiate...at this time."72

\footnotetext{
${ }^{71}$ R.S. Hensley to Clyde Ellis, February 4, 1942, and Clyde Ellis to R.S. Hensley, February 9, 1942, Ellis Papers, box 5 , folder 33 .

${ }^{72}$ Geo. L. Bell to Clyde Ellis, June 6, 1941, and T.F. Kern to Clyde Ellis, June 20, 1941, Ellis Papers, box 5, folder 32.
} 
Tempers boiled among some dispossessed rural folks, and a few angry opponents resorted to violence. Though Baxter County Sheriff Harvey Powell "found no clues of value" upon which to pinpoint any suspects for arrest, some angry arsonists set fire to a "recently erected" store building at the dam site in late August 1941, not long after workers had finished diverting the flow of the North Fork River from its original channel and started building the massive concrete structure that would become the hydroelectric power-generating dam. Luckily for the store building's owner and the rest of the new properties under construction at the newlyplatted government-owned town, workers and Corps officials staying at the site noticed the blaze and "extinguished [it] before it got well underway." When local authorities arrived to the damaged building to investigate, they found a back door busted open and an empty kerosene jar "lying open in the rear room" with its contents "poured over the floor." Though the unknown arsonists inflicted far less damage than they had hoped, the store's owner suffered a significant financial loss because he had not yet purchased fire insurance on the building. ${ }^{73}$

The vast majority of rural folks disaffected by the dams eschewed such violent retaliation, however. A handful of more prosperous and better-connected hill folks filed or threatened lawsuits and circulated petitions objecting to what they deemed to be unfair treatment by the government's land acquisition schemes. In the fall of 1940, sixty-eight-year-old S.J. Hutcheson, a prominent landowner, stockman, and retired Main Street merchant at the old town of Norfork, filed a suit against the government in the U.S. District Court at Harrison. The Corps had offered Hutcheson $\$ 1,250$ for a 129.3-acre tract of riverside land located upstream from the dam site that it had condemned for the reservoir project, but he insisted that it was worth much

\footnotetext{
73 “Arson Suspected in Fire Started in Vacant Store Building at Norfork Dam Site," Baxter Bulletin, August 28, 1941.
} 
more than that. A few years before, Hutcheson had rented this part of his large farm to the Arkansas Power and Light Company, which had considered constructing a small powergenerating dam on that portion of the North Fork River before the Corps's project was approved by the federal government. Hence, Hutcheson claimed the land held a special "availability" value, along with its agricultural value, and was worth at least an additional $\$ 10,000$.

Nevertheless, he proposed to settle with the government for $\$ 4,300$. When the Corps refused his counteroffer, Hutcheson sued. Hutcheson died about a month before the October court term commenced, but his heirs pursued the case. On October 9, Judge Harry J. Lemley and the jury traveled by bus from Harrison to visit the disputed land in Baxter County to determine for themselves whether the government had made a fair offer to the landowner. The following day, the court ordered the Corps to double its original offer, awarding the Hutcheson heirs $\$ 2,500$ for the land. ${ }^{74}$

The Hutcheson heirs, led by Jack Bonner, sued the government again the following spring. This time the family disputed the government's offer to compensate them for the acquisition of right-of-ways through other parts of their land to build a new highway and a new eight-mile railroad spur to connect the dam site to the main tracks in the town of Norfork. Bonner and some of the other heirs had already begun investing in and developing the Hutcheson lands near the dam into a new lake-front town site, and they had told local reporters in April 1941 that "our lots are selling well and we expect to build up a good town on the site." The Hutcheson heirs likely welcomed the decision to route the new highway and railroad through the family's booming property, but they hoped that holding out in federal court would force the

\footnotetext{
74 "Will Argue Suit Over Dam Site," Harrison Daily Times, October 6, 1940; “Federal Court Jury to Norfork Dam," ibid., October 9, 1940; “\$2,500 Judgment Awarded in Land Condemnation Case,” ibid, October 10, 1940.
} 
government to fork out more money for the right-of-ways. Their efforts paid off. The jury once again made the trip from Harrison in October 1941 "to personally view the site," and the court required the government to increase its purchasing price and pay an additional six percent interest to the Hutcheson heirs since it had taken possession of the land from them a year before the case was settled. ${ }^{75}$

A few other better-off landowners also embarked upon a litigious path of resistance. As late as the fall of 1942, S.R. Seward, Don Chapin, Lon Jones, and a few other farm owners organized a petition to challenge the government's land condemnations above the Norfork Dam to make way for the area that would contain the 22,000-acre lake. They acquired an attorney and threatened to slow the construction of the reservoir by filing for an injunction and tying the matter up in court. They sent the petition straight to their powerful local political friends, Tom Shiras, Rex Bodenhammer, Tom Dearmore, and other Mountain Home boosters, and "insisted" that they pressure federal officials to do something about the landowners" "troubles." They primarily complained that the government was shorting them with low-ball offers to compensate them for the land it was taking. Bodenhammer wrote Congressman Ellis "to find out whether you could and would try to get an adjustment made without their going into court." While he "realize[d] that any improvement will cause a hardship on someone" and did not believe "it is the intention of the Government to damage anyone," Bodenhammer admitted that his farmer-friends

\footnotetext{
75 “Condemn Land for Norfork Dam Railroad," ibid., April 3, 1941; "Wilderness Becomes Industrial Scene at the Norfork Dam Site"; Civil Action No. 55, Western District of Arkansas, Harrison Division, United States Court, October 1941.
} 
"are justified in asking" for more just compensation for their lands, because "some of these petitioners' farms have been appraised way too low." 76

Though they occasionally invited poorer neighbors to join their lawsuits, the few wealthier landowners in the area were typically the only ones with sufficient resources to follow through with their threats to challenge the federal government in court, and they usually did so only to hold out for more money. Instead, the responses of a vast majority of poor and middling hill farmers dispossessed by the Corps's dam projects probably resembled that of Billy D. Potter's family in the Higden community in Cleburne County.

Potter's farm near the Little Red River had been in the family since his grandparents, James and Mary Cody, migrated from Tennessee and settled the small tract of Ozarks hill ground in the 1880s. Born in 1918 in the original house that his grandparents had built, the young Billy later helped his family survive the Great Depression and maintain the farm by supplementing the family's scanty agricultural income with part-time work at a local sawmill and employment with the federal government's Civilian Conservation Corps. In April 1942, Potter's father died unexpectedly from a massive stroke after he and Billy had finished clearing some new ground to expand their farming operation. The family's loss left the twenty-four-year-old Potter "the full responsibility of making a crop, running the farm, and taking care of his mother and younger sister." Potter married the following month, and he and his new bride, Claudia, conceived their first child a few weeks later. That summer, Potter received word from Uncle Sam that the U.S. government had drafted him for military service in the Second World War, but the Army granted

\footnotetext{
${ }^{76}$ Rex Bodenhammer to Clyde Ellis, November 4, 1942, Ellis Papers, box 5, folder 33.
} 
him a discharge so he could return and care for his family after his son was born in late January $1943 .{ }^{77}$

Back in Cleburne County, Potter supported his family with a combination of semisubsistence farming, raising livestock for the market, and growing corn and cotton as cash crops. In order to keep the family farm viable amid the cutthroat capitalism of America's postwar agricultural economy, Potter significantly expanded production during the 1940s and 1950s. In addition to maximizing production on the family's modest-sized hill farm, Potter rented several acres of fertile bottom ground in the area's narrow river and creek valleys from three different landowners, where he also grew corn and cotton for the market. By the late 1950s, after many of their backcountry neighbors and extended family members had packed their meager belongings and fled the opportunity-strapped community, the Potters had managed to preserve the family farm and sustain their smallholder livelihood in the rural Ozarks. ${ }^{78}$

In the summer of 1959, the Potters' lives suddenly changed when the federal government notified them that they must turn over their farm to the Corps of Engineers for the construction of the Greer's Ferry Dam and Lake. The Corps later made its offer to compensate them for the land, but the family believed that "there was no way the amount of the settlement could replace what was being taken," especially since it included only a "minimal allowance for the improvements on the land." Potter's daughter, Karen, who was a high-school sophomore at the time, remembered the stress imposed upon her father and the rest of the family as they attempted to navigate the dislocation. While they considered fighting the government, she explained that

\footnotetext{
${ }^{77}$ Karen Potter Murphy, Higden ...A Place in the Heart: Life before Greer's Ferry Lake (N.p: Create Space Independent Publishing Platform, 2013), 2-16.

${ }^{78}$ Ibid., 130-131.
} 
"Dad knew the only other option was a formal appeal, which would tie up any settlement until all court proceedings were completed, a minimum of several months, could be years." The family simply could not afford the expense and uncertainty. Her father "was a farmer," she continued, "and he could not afford to miss planting a crop in the Spring, so he reluctantly accepted the Corps' settlement offer and began to focus on getting relocated."

By the fall of 1959, while they scrambled to harvest their crops and keep up with other demands on the farm, the Potters made arrangements to purchase a farm in Craighead County in the lowlands of northeastern Arkansas near the home of some relatives. Then they began transporting corn, hay, and other farm products and equipment to the new farm in Craighead County, a round-trip of about 300 miles. In all, Karen recalled that her father made "a total of about forty trips moving everything he needed to move," mostly at the family's own expense, since "the Corps' monetary settlement included only a very small allowance for moving expenses." Though he transported some of his livestock to Craighead County, Potter sold off many of the family's cattle and hogs. Except for a few cows - "enough for a small herd at the new farm"-Potter sold most of his "100 head of Hereford cattle," in addition to all but "a load of hogs." After Christmas - which Karen later described as "the saddest Christmas I've ever experienced"- the Potters started moving their household items. Though they had "procrastinated even acknowledging the reality of it as long as possible," the Potters finally vacated the old homeplace and family farm a few weeks later in the early winter of $1960 .{ }^{80}$

\footnotetext{
${ }^{79}$ Ibid., 147-148.

${ }^{80}$ Ibid., 1, 148-150.
} 
Soon after the Potters arrived at their new farm in northeastern Arkansas, Karen remembered her aging grandmother, whose parents had originally homesteaded the family farm in Cleburne County in the 1880 s, sitting on the porch swing one rainy day and remarking as she peered out across the flat and treeless terrain: "It ain't the same, is it?" Though the Potters soon became "very busy with the demands and activities at the new place," Karen recalled that "the move was very traumatic for all of us, heart-wrenching, actually." By the time they returned to Cleburne County in May 1960 to attend a relative's high-school graduation, their "former community was only a skeleton of itself." "So many houses and barns were gone," she recollected, "that you could barely tell where families had lived only a short time before." During another visit "home" in August 1961, shortly after the Corps closed the flood gates and began filling the new lake, she remembered her resentful father commenting as the family crossed a bridge overlooking the flood zone: “They took our farm and made us move, but I don't believe that lake will ever cover as much ground as the Corps says it will." "Dad's doubt was soon proved wrong," she explained. When President John F. Kennedy arrived to Cleburne County on October 3, 1963 to dedicate the Greer's Ferry Dam (which turned out to be Kennedy's last public appearance before his assassination the following month) and applaud these public "investments which will make this a richer state and country in the years to come," the Potters continued their struggles to "recover" from this "painful" and "transitional time" and to remake their lives outside their native region. ${ }^{81}$

\footnotetext{
${ }^{81}$ Ibid., 1, 150-151; “Address by President John F. Kennedy, Dedication of Greer’s Ferry Dam, Heber Springs, Arkansas, October 3, 1963," reprinted in the program of the Greer's Ferry Dam 50 ${ }^{\text {th }}$ Anniversary Dedication Ceremony, October 3, 2013, in author's possession.
} 
The plight of the Potters notwithstanding, dispossession by the Corps's dam projects typically spelled the end of family farming altogether and brought about even greater transformations for most rural folks who were forced to relocate. The small cash payments distributed by the federal government to compensate rural families for their "poor hill ground" prohibited most from buying farms elsewhere that were large enough to provide an adequate income to sustain their way of life as smallholder producers. Most joined the mass exodus from rural backcountry communities to start life anew in places like the sprawling industrial zones of California and Illinois or more urbanized regional centers in Arkansas and other parts of the western South. Even those backcountry folks whose small farms were not taken by the government and stayed attached a while longer usually underwent similar experiences. Indeed, the vibrant opportunities for small hill farmers that local boosters had promised would emanate from the general "progress" created by the Corps's dams never materialized. Even Tom Shiras had to admit in 1945- two years after the completion of the Norfork Dam — that "no extensive boom took place around the dam" like many had envisioned, though he continued to insist that "opportunities are here for a long-neglected section of the United States.. $" 82$

The federal government began building the even larger Bull Shoals Dam on the White River in 1947, so hundreds of rural locals in Baxter, Marion, and surrounding counties - many of whom were returning World War II veterans—-temporarily benefitted once again from the decent-paying and much needed construction jobs it created. Most of these government-funded paychecks ended, however, after contractors finished the biggest part of the project in 1952. Marion County native Doyle Hurst remembered that, though the "rural Ozark area thrived"

\footnotetext{
${ }^{82}$ Shiras, "Norfork Dam," 157.
} 
around several small towns in the vicinity of the dam while it was under construction, "there was a severe job shortage" after the Corps and its contractors finished the project and moved out in $1952 .{ }^{83}$ Ultimately, dam "progress" failed to stem the long-term flow of rural decline and outmigration.

The lion's share of the permanent economic benefits generated by Norfork and Bull Shoals dams went to the town of Mountain Home in Baxter County. "Ideally situated about midway between the two projects," Mountain Home rapidly transformed from a small countyseat town and local trading village with fewer than 600 people in 1930 into a blossoming tourism, recreational, and retirement center of more than 2,200 people by the 1950 s. Even before it felt the full impact of the new Bull Shoals Lake, the town had become "the third most popular destination for retirees in Arkansas, and Baxter County boasted over 150 resorts, lodges, hotels, and restaurants." In keeping with the national trends of postwar suburbanization, Mountain Home continued growing its tourist- and consumer-based economy during the following decades and reached a population of more than 8,000 by 1980 and almost 12,500 by $2010^{84}$

Similarly, the town of Heber Springs harnessed most of the economic growth fueled by the Greer's Ferry Dam. While economist Christopher Garbacz claimed in a 1971 article in Land Economics that the Greer's Ferry Dam and Lake had contributed "substantial benefits" for "economic development in this depressed area" of the Ozarks in Cleburne and Van Buren

\footnotetext{
${ }^{83}$ Doyle Hurst interview by Aaron Williams, April 19, 1999, published in South Shore Memory Project Archives (http://ozarkhistory.com/archive/SouthShore/t-Doyle\%20Hurst.htm), accessed December 18, 2013.

${ }^{84}$ Clement Mulloy, "Mountain Home (Baxter County)," Encyclopedia of Arkansas History and Culture (http://www.encyclopediaofarkansas.net/encyclopedia/entry-detail.aspx?entryID=826), accessed December 18, 2013; Blevins, Hill Folks, 192.
} 
counties due to rising levels of per capita income and job creation, he had to admit that there were "certainly complex analytical problems" in gauging costs and benefits. Based on statistics for 1969, Garbacz estimated that the ripple effect of the dam's economic impact after its completion had "directly" or "indirectly" created about 1,253 new jobs, accounting for more than 26 percent of the total employment in the two-county area. He confessed, however, that these statistics did not disclose the fact that "certainly some of the new employment was absorbed through in-migration" and that a disproportionate number of the jobs were subject to "seasonality of employment and low earnings potential." Garbacz also acknowledged that "non-residents" and recent in-migrants now owned a large portion of the local wealth. In 1970, for instance, nonresidents (not including recent permanent in-migrants) owned $\$ 11.25$ million of the $\$ 27$ million value of housing properties "adjacent to the lake." Furthermore, Garbacz noted that residents in towns and communities in the area "have not prospered equally." A comparison of per capita personal income in Cleburne and Van Buren counties between 1960 and 1967 revealed this unevenness, not to mention the marked disparities from community to community within the two counties. While Cleburne County, mostly reflecting the growth of Heber Springs, had climbed the ladder in Arkansas's per capita income rankings from number 56 to 35 out of its 75 counties, Van Buren County actually fell from 67 to 70 on the list. Another study of similar dams and lakes in the Missouri Ozarks, moreover, indicated that "in many cases, poverty had increased in counties with dams even though there had been immigration by higher income government workers and well-to-do retirees." ${ }^{.85}$

\footnotetext{
${ }^{85}$ Christopher Garbacz, "The Ozarks: Recreation and Economic Development," Land Economics 47 (November 1971): 418-421; Payton and Payton, Damming the Osage, 258-259. On poverty and dams in the Missouri Ozarks, the Paytons referenced the findings of rural sociologist Rex R. Campbell's paper, "Influence of Lakes on Population Change and Characteristics: 1960-1970."
} 
As Ozarks historian Brooks Blevins puts it, "The dams would bring prosperity to the region, though not always to its people." In writing about the impact of the Corps's pilot project in Baxter County, Blevins explains that "the long-term effects on the human community in the Norfork Dam area in many ways paralleled the effects on the fish community," after the government constructed a new fish hatchery to introduce nonindigenous trout species into the cold-water stream below the dam. "Retired and entrepreneurial midwesterners poured into the Mountain Home area, replacing those uprooted by the dam and the hundreds more whose agricultural pursuits failed to support them after World War II." "The newcomers, like the brown and rainbow trout," Blevins suggests, "were and are most often non-reproductive; they lived out their lives in an environment quite different from the one heritage had provided until they were replaced by another Midwestern retiree at death. But they came to northern Arkansas in large numbers" seeking comfort and prosperity in the New Ozarks, while hundreds of capitalstrapped natives exited the region's rural communities en masse. ${ }^{86}$

The experiences of many native-born rural Ozarkers who managed to stay in their home areas during this era of regional transformation resembled those of Harlin Pierson, Jewell Tilley, and Doyle Hurst of Marion County. Pierson had helped sustain his family during the Great Depression by supplementing their small farm income with part-time work for a local dairy farmer and by cutting stave bolts for extra cash. He then received employment with the Civilian Conservation Corps at Dierks. During the late 1940s and early 1950s, Pierson worked as a rotary driller on the Bull Shoals Dam project. After that temporary job ended in 1952, he scraped by raising livestock for a few years before the government placed him on its payroll as a local park

\footnotetext{
${ }^{86}$ Blevins, Hill Folks, 192.
} 
ranger. He later received a promotion to become a park superintendent. Thus, Pierson managed to remain in his home area and retired comfortably with a government pension after eighteen years. $^{87}$

Jewell Tilley remembered that the depression "was dang hard" and that he helped keep his family's farm afloat with extra "cotton pickin"” wages and a much-needed WPA job during the late 1930s and early 1940s. Though that "bunch of Republicans...By God...starved us out," Tilley explained, Roosevelt "started all that work" and "got things to goin'." "A lot of people forgot that, but by gosh we didn't," he continued. The jobs provided by the government's dam projects in the area during the 1940s and early 1950s, furthermore, "helped out a whole lot," he explained. After the Corps and its contractors finished the Bull Shoals Dam, Tilley went to Washington State and found work on a giant corporate farm and seed company, which he recalled had a "big orchard," "900 acres of potatoes," a large alfalfa and clover ranch, a bee farm, and other sectors of agricultural production. Having made "pretty good money" there, he returned to Marion County a few years later and bought 200 acres on the "mountain" to add to the family farm in the Rea Valley, where he primarily raised livestock. He supplemented his farm income by guiding trout fishermen below the Bull Shoals and Norfork dams for Elmo Hurst's recreational guiding and outfitting business. Though he later sold much of the farm when he and his wife divorced, Tilley retired on his forty-acre homeplace and continued raising "a few cows" into the 1990s. ${ }^{88}$

\footnotetext{
${ }^{87}$ Harlin Pierson interview by Tracey Chandler, April 9, 1999, published in South Shore Memory Project Archives (http://ozarkhistory.com/archive/SouthShore/t-Harlin\%20Pierson.htm), accessed December 18, 2013.

${ }^{88}$ Jewell Tilley interview by Brad Goeke, February 10, 1999, published in South Shore Memory Project Archives (http://ozarkhistory.com/archive/SouthShore/t-J.Tilley.htm), accessed December 18, 2013.
} 
Doyle Hurst was born only a few months before the U.S. entered the Second World War, but he remembered his family's economic struggles in rural Marion County. His father worked as a construction worker on the Bull Shoals Dam, but the subsequent "change in the supply [of local employment] forced the Hurst family to move frequently in the summertime" after the project ended. The Hursts maintained their homeplace and small farm in the Ozarks but went to Texas and Montana to find work between spring planting seasons and fall harvests. During one summer in Montana, the young Doyle worked at a grocery store to help contribute to the family's income. With the help of this seasonal employment as migrant workers, the Hursts maintained their place in the rural Ozarks. After Doyle Hurst graduated from the local Flippin High School, he went to the University of Arkansas in Fayetteville. Then he attended Oklahoma State University, where he earned a doctorate degree in education. Upon completing his education, Hurst "came back to his roots" in the rural Ozarks to teach at the local high school. ${ }^{89}$ While many hill folks were unable or unwilling to stay in the rural Ozarks, those like Pierson, Tilley, and Hurst who did usually had to turn to economic endeavors off the farm—and oftentimes outside the region altogether-to survive during the second half of the twentieth century.

The predominantly rural areas of the region remained some of the most impoverished locales in the nation, but life had changed dramatically in the Ozarks between the 1930s and 1960s. Ozarkers had continued to demand that their government intervene to promote economic justice during the Great Depression and supported populist political leaders who promised to redistribute American power and prosperity to hardworking common people. Armed with the

\footnotetext{
${ }^{89}$ Doyle Hurst interview.
} 
unprecedented powers of an expanded government, New Dealers provided much-needed relief to desperate hill folks, but most of their programs only temporarily assisted rural families and wound up mostly serving the interests of the local elites who ran them. In the long run, in fact, because they primarily aimed to help distressed country folks by integrating them more firmly into an agricultural and industrial capitalism that had little room for small producers, many of the government's rural programs helped exacerbate the extinction of family farming.

Nevertheless, as rural economic desperation reached new depths, fewer and fewer backcountry Ozarkers opted for the paths of defiant resistance that some hill folks had taken during the moonshine wars, the controversial military draft of the First World War, and the government's burdensome agricultural "improvements" during the previous three decades. With practically no viable alternatives on the table, most struggling rural folks pragmatically welcomed any help they could get that enabled them to work to support their families. Aside from the handful of hill folks literally displaced by federal land condemnations, a majority of rural Ozarkers joined regional elites and boosters to support government infrastructure projects such as the Army Corps of Engineers's dams. Many of them undoubtedly agreed with one liberal-progressive's assertion that, since there was "no ongoing or planned program to upgrade the mobility of the labor force" and because a "direct subsidy to improve employment prospects in the rural underdeveloped regions in not likely on any large scale," the benefits from these dams and similar government projects, however limited, "may be at least a partial solution to underdevelopment in rural areas. ${ }^{, 90}$ Indeed, despite their limited benefits—or, perhaps, because of their limited benefits — dam building and other government-funded development projects in

\footnotetext{
${ }^{90}$ Garbacz, "The Ozarks: Recreation and Economic Development," 421.
} 
the Ozarks became "addictive." 91 At last, the New South vision and its favored status in government had won the Ozarks. The liberal state's yielding to local and regional elites and their ideals of "progress" effectively pitched agrarian-populism into the dustbin of history.

Ever since the late nineteenth century, all the while that they called on a more powerful government to promote economic justice, rural Ozarkers had gradually adapted more and more to an industrial- and agribusiness-dominated political economy as they tried to make ends meet. But hill folks during the post-World War II era became more thoroughly dependent than ever before on America's growth- and development-oriented capitalism. And the now-larger American liberal state's continued adherence to the tradition of federalism and shared authority with state and local officials ensured not only that New Ozarks elites maintained the privilege of implementing most government programs designed to help the poor and common folks but that they also held the preeminent position to shape the debates about problems and limitations that arose. Consequently, changes in the New Ozarks of the postwar era spurred a shift in the dynamics of defiance in the region. With the exodus of many agrarian-populists from family farms in the region's old backcountry, the absorption of most rural folks who remained into the periphery of America's industrial- and agribusiness-based economy, and a growing population of middle-class in-migrants primarily from the Midwest seeking their advantages in the New Ozarks, residents of the Arkansas hill country eased up on their forefathers' clamors to make the

\footnotetext{
${ }^{91}$ Payton and Payton, Damming the Osage, 300. Indeed, a major political fight erupted during the 1960s and 1970s between local pro-dam supporters in Searcy and Newton counties and a group of conservationists centered in northwestern Arkansas over the Corps's proposal to construct a dam on the Buffalo River. The conservationists, led by Neil Compton and the Ozark Society, won the political battle and lobbied the National Park Service to protect the free-flowing stream as a national river, raising the ire of most dam supporters even more and also that of a number of local landowners. See Neil Compton, The Battle for the Buffalo River: A Twentieth-Century Conservation Crisis in the Ozarks (Fayetteville: University of Arkansas Press, 1992) and Dwight T. Pitcaithley, Let the River Be: A History of the Ozark's Buffalo River (Santa Fe: Southwest Cultural Resources Center of the National Park Service, 1978).
} 
"capitalists howl," as Jeff Davis had proposed. Now, many of the most impassioned expressions of "damn guv'ment" defiance in the region would be instigated by those New Ozarks elites who were determined to fight any and all government interventions that they felt might impede their rightful share of America's capitalist growth. 


\section{Chapter Seven}

\section{Growing the Hills}

Martha Wagner was dismayed at what she saw happening to her rural farm community in Cleburne County in 1952. "Just a little old woman here on Pryor Mountain" near Quitman, where she had lived for "most of 50 years," Wagner felt helpless as she watched her small farming community wither away because, as she explained, "ever-Body is leaving here to hunt work." In late January she decided to write Governor Sidney McMath and "put in a plea for my good neighbors and friends," feeling that "I just had to do something if I could for our People here." Small farmers in Cleburne County who typically owned "from 3 to 120 acres" of "Just Plain Hill land," she told the governor, "will grow eney-kind [sic] and all kinds of vegetablesfrom corn to pumpkins." "But here is the trouble - they cant [sic] sell what they grow [because] there isent [sic] eney [sic] market here." "But if we had a Big government Canner or Compney [sic] Canner here that would Can and Buy what they Raise," Wagner thought, "People could stay on their homes and Raise stuff and have a good income to [sic] and not half [sic] to leave and go to Calif. or Mich. to work." "Please Mr governor," she pleaded, "will you help us get a canner here so folks can keep their homes and at the same time Help enable them to feed the World $[?]^{\prime \prime 1}$

Wagner must have figured that if any political figure would listen and act, it would be Governor McMath. McMath stood as the torch-bearer of New Deal populism at the state level in postwar Arkansas, having ridden into the governor's office in 1948 as a "popular progressive"

\footnotetext{
${ }^{1}$ Martha Wagner to Governor McMath, January 29, 1952, Sidney McMath Papers, series I, box2, file 12, folder 3, Arkansas History Commission, Little Rock.
} 
reform leader. McMath and his liberal allies had managed to keep conservatives and racebaiting Dixiecrats from dominating Arkansas's Democratic Party like they had come to do in most other southern states, and during his two terms in office the "reform-minded" governor oversaw a number of progressive measures that expanded the role of the state government. These included "an unprecedented highway-construction" program, "improved health care," educational reform, and critical "support for the rural electric cooperative movement" against the obstructionist lobby of the mighty Arkansas Power and Light Company. Moreover, the McMath-sponsored "legislation that more than doubled the annual budget of the labor department, increased minimum-wage laws, and strengthened industrial-safety codes" joined other popular state reforms to boost the governor's populist image among Arkansas's common and working folks. ${ }^{2}$

McMath's brand of "progressivism," however, remained in stride with most other postwar American liberals who stood committed to the promise of capitalist prosperity and viewed the government-supported expansion of industrial growth and development - not so much redistributive and regulatory policies — as the key to solving social and economic problems, including rural decline. In his response to Wagner, McMath assured her that the rural "problem" she spoke of "has come to my attention many times since I have been Governor of this State," but he could offer her and her neighbors little recourse for sustaining their small-farm livelihoods. "There is no provision whereby a state can provide a market for the fine products which are raised in your community and many others in America," he explained. Nevertheless,

2 James E. Lester, "Sidney Sanders McMath, 1949-1953," in The Governors of Arkansas: Essays in Political Biography, Second Edition, edited by Timothy P. Donavan, et al., (Fayetteville: University of Arkansas Press, 1995), 210-215. 
he confidently predicted that his state-sponsored development programs would spur new capitalist growth in Arkansas that would help fix the rural crisis and encourage future prosperity for all. "I am doing everything possible to provide a good improved highway system in the state," he told Wagner. "I feel that once this is done that private industry will come into Arkansas and will set up factories and processing plants thereby providing a market for the natural products of Arkansas." "I assure you,” McMath pledged, "I am doing everything possible to provide a better life for the ordinary citizens of Arkansas."

The correspondence between Wagner and McMath represented many Ozarkers' continued hope in the power of a just government to help provide security and sustainability for rural families and communities during the postwar era. Despite unprecedented economic prosperity in America after the Second World War, life on small family farms - with its promise of greater independence - was coming to a rapid end after a half-century or more of struggles for survival against an increasingly hegemonic capitalist political economy and its powerful supporters locally and nationally. Depression remained fixed in the vast majority of rural communities across the Ozarks, and outmigration to larger towns and cities, thus far, proved the only way to escape. Folks like Martha Wagner, however, hoped that the same "peoples' government" that had so successfully mobilized and channeled its collective commitment and resources to guarantee Americans' security and prosperity abroad and on the home front during the recent world war could help preserve and protect rural life in the heartland.

The exchange of letters between Wagner and McMath, however, also represented the persistence of American progressives' delegation of the liberal state's power and resources to

\footnotetext{
${ }^{3}$ Sid McMath to Martha Wagner, February 12, 1952, McMath Papers, series I, box 2, file 12, folder 3.
} 
local elites and their visions of "progress." Postwar progressives, both locally and nationally, aimed not to revive what they believed to be a worn-out and outdated small farm economy but, instead, to bring "modernity" to the Ozarks and other depressed rural regions by opening the door of "opportunity" afforded by industrialization. They sought to utilize government power to break down barriers of isolation and to pump resources into these "lagging areas" left behind in an otherwise affluent America. Leaving the administration of government power and resources in the hands of local and regional elites who presumably "knew best" about how to deal with particular circumstances on the ground, the postwar liberal state set out to "grow" and "uplift" rural Ozarks communities out of their "exceptionalism" and "otherness" by integrating them more completely into mainstream America's burgeoning capitalist industrial economy.

Many rural Ozarkers remained hopeful and proved receptive to the John F. Kennedy and Lyndon B. Johnson administrations' designs to use the liberal state to help their region "grow" and "develop" its way to newfound prosperity. By 1966 federal, state, and local officials created the Ozarks Regional Commission (ORC), one of five new regional development commissions in the United States authorized under Title V of the Public Works and Economic Development Act of 1965. The mountainous, "underdeveloped" Ozarks seemed the logical choice to follow the federal government's larger pilot program in Appalachia amid its regional development plans. The story of federal regional development efforts in the Ozarks, however, was one of initial high hopes that turned rather quickly to disappointment. The ORC and the other Title V commissions, unlike the independent Appalachian Regional Commission, operated within the Department of Commerce and never transcended their secondary status in the broader regional development program. Unlike in Appalachia, where some level of regional consciousness and coordination already had roots among political and economic leaders, calls for a regional 
program in the Ozarks came only after the announcement of the Appalachian program aroused concerns about federal favoritism from leaders in other economically distressed regions. The later formation and start-up of the Title V commissions amid the escalating war in Vietnam and national political conservatives' increasing assaults on social programs ensured that the ORC would receive low priority. Furthermore, state and local development officials who controlled most of the ORC's projects advanced a "trickle out" industrial vision that helped promote an uneven process of economic development that aided already more prosperous "growth centers" at the expense of the poor rural areas that had been held up to justify the government's regionalism concept in the first place. Most rural Ozarkers, then, received little but disappointment from the postwar liberal state's economic reform efforts.

In a November 1965 Wall Street Journal article titled "Echoes of Appalachia," reporter James C. Tanner drew national attention to the "Poverty-Ridden Ozarks" in middle America. Pointing to the distressed conditions of Newton County in northwestern Arkansas where over one-third of the citizens were on welfare and per capita income was less than one-third of the national average, Tanner described "a land characterized by outmigration, a rising median age of residents, depreciating tax bases, inadequate schools, few public facilities and a limited road network." Tanner continued: "If all this sounds like Appalachia, the Ozarks ... have much in common with that 11-state mountain area. ... But while Appalachia draws the headlines and massive doses of federal aid, the economic situation in the Ozarks continues to deteriorate." "Stirrings of hope" were, however, in the air, he remarked, since Pres. Lyndon Johnson had recently signed a major public works bill authorizing regional planning programs for the Ozarks and other depressed areas modeled on the Appalachian Regional Commission's (ARC) \$1 billion federal aid program. "Much of the new hope," he explained, “... rests on the prospect of help 
from Washington." Against the backdrop of postwar liberalism's heyday, many comfortable, yet compassionate, observers felt confident that rural poverty might be solved by offering government assistance to help pour the blessings of more capitalist growth into the region. ${ }^{4}$

In the words of historian Godfrey Hodgson, "The United States entered the 1960s in an Augustan mood: united, confident, conscious of a historic mission, and mobilized for the great task of carrying it out." The World War II era had produced "an economic leap forward, which gradually engendered a new social optimism," an unwavering faith in American capitalism that promised to "produce abundance on such a scale that social problems would be drowned under a flood of resources." Amid the excitement and confidence, however, a few keen observers such as intellectual and social activist Michael Harrington turned the nation's and its political leaders' attention to "another America" that existed within the country's borders. An "invisible land" in rural and urban places hosted a "culture of poverty" that America's ascendancy had left behind. America, Harrington professed, was obligated to bring these forgotten people into the line of progress, for "society must help them before they can help themselves."

No rural people better epitomized the "Other America" than residents of the southern highlands. "There's nothing wrong with hillbillies—a description which Mountain people loathe - that a strong dose of equal opportunity wouldn't cure," wrote Harry W. Ernst and Charles W. Drake in an article published in The Nation in 1959. "Applying every yardstick of social well-being, their Appalachian homeland emerges a sordid blemish on the balance sheet of

\footnotetext{
${ }^{4}$ James C. Tanner, "Echoes of Appalachia: Poverty-Ridden Ozarks See a Brighter Future if U.S. Aid Materializes," Wall Street Journal, November 13, 1965.

${ }^{5}$ Godfrey Hodgson, America in Our Time: From World War II to Nixon-What Happened and Why (New York: Doubleday, 1976), 12, 18.

${ }^{6}$ Michael Harrington, The Other America (New York: Macmillan, 1962), quoted in Maurice Isserman and Michael Kazin, America Divided: The Civil War of the 1960s (New York: Oxford University Press, 2008), 111.
} 
the wealthiest nation in the world."7 Amid the high hopes for American capitalism in the postWorld War II era, the unemployed coal miners, dispossessed small farmers, and generally impoverished families of Appalachia reminded middle-class America that the promise of unbounded prosperity was still a work in progress. In eastern Kentucky alone, mechanization enabled coal companies to slash mining employment by 62 percent between 1950 and 1960, despite high levels of coal production and profits. ${ }^{8}$ Thousands of mountaineers hit the migrant trails to northern or western cities to escape the depressed region, but destitution and desperation engulfed those who remained. Confident that this "blemish" could be healed, however, policymakers and activists made Appalachia a central battleground in a national antipoverty crusade.

John F. Kennedy’s campaign for the Democratic primary in West Virginia in 1960 cast the spotlight on Appalachia's poverty. Needing to prove that his Catholicism would not prevent him from being elected president, Kennedy sought to win the predominantly Protestant and politically important state of West Virginia, and his success over contender Hubert Humphrey there showed that his religion would not be a prohibitive factor. Kennedy's campaign through the Mountain State drew significant attention to Appalachian poverty, and it left a major impression on his ideas for future policy. In the words of historian Jerry Bruce Thomas, “Although Kennedy's background of wealth and privilege provided him with little understanding of poverty and the struggles of less affluent Americans, his time in West Virginia had awakened in him sympathy for the unemployed coal miners and rural poor of Appalachia.” Kennedy

\footnotetext{
${ }^{7}$ Quoted in Jerry Bruce Thomas, An Appalachian Reawakening: West Virginia and the Perils of the New Machine Age, 1945-1972 (Morgantown: West Virginia University Press, 2010), 126.

${ }^{8}$ Helen M. Lewis and Edward E. Knipe, "The Colonialism Model: The Appalachian Case," in Lewis, et al., ed., Colonialism in Modern America: The Appalachian Case (Boone, NC: Appalachian Consortium Press, 1978), 11-12.
} 
promised West Virginia that once elected he would put forth a comprehensive program to improve the state's and other depressed areas' economic suffering. ${ }^{9}$

The Ozarks was one of the other areas suffering intense poverty and economic underdevelopment, despite the immense changes it had already undergone since the 1940s. But as historian Brooks Blevins notes, "Unlike Appalachia, which became a cause célèbre during the 1960s' war on poverty, the Ozarks never entered the mainstream consciousness as a region racked by unbelievable poverty and distress." For one thing, the Ozarks did not have a Harry Caudill, the Kentucky lawyer and activist whose widely read Night Comes to the Cumberlands (1962) exposed the blatant exploitation that industrialists, especially coal companies, had wrought upon the land and people in Appalachia, leaving chronic poverty and dependency in their wake. While industrialization, as we have seen, had certainly brought significant change to the Ozarks since at least the latter part of the nineteenth century, the more obvious scars that industries such as coal mining had left on the land and people of many parts of Appalachia were at least small enough in its sister region to the west to avoid the same eye-grabbing media attention. Thus, especially with the help of travel writers and tourism boosters-many of them from within the region - the Ozarks remained an unspoiled land of romantic simpletons living in the bygone years in mainstream America's popular imagination. "Whether consciously or unconsciously," writes Blevins, "the Ozark region had been relegated to almost pure image, a land that apparently embodied the rural and pastoral virtues of a largely mythological American past, yet one not worthy of serious thought or respect." With only a few exceptions, such as Tanner's 1965 Wall Street Journal article, the Ozarks was mostly a beautiful and quaint travel

\footnotetext{
${ }^{9}$ Thomas, An Appalachian Reawakening, 127.
} 
destination in the American consciousness, and not a "wretched" and economically distressed region like Appalachia. ${ }^{10}$

Nevertheless, this image overshadowed the serious poverty that actually plagued the rural region. In 1959 the annual per capita income in the Ozarks stood at only 60 percent of the national average; while the nation's average per capita income was $\$ 1,850$, it was only $\$ 1,242$ in the upland counties of southern Missouri, northern and western Arkansas, and eastern Oklahoma. With the region's population at about 2.5 million in 1960, a federal report in 1967 indicated that the per capita income gap represented about a $\$ 1.5$ billion income deficiency in the Ozarks. ${ }^{11}$ Over 44 percent of Ozarks families had annual incomes of $\$ 3,000$ or less in 1960 , a poverty figure more than double the national average. Interestingly, the Ozarks poverty rate was nearly 14 percent higher than the aggregate rate of Appalachia (as defined by the ARC), the symbol of rural poverty in the nation. ${ }^{12}$

The transformation of agriculture in the postwar years, which was precipitated by both technological innovations and government policies that acceded to the demands of agribusiness interests and encouraged farm consolidation, profoundly hastened the demise of small-farm communities and economies of the Ozarks. Adding to the rapid declension of family farming that had occurred during the 1940s, the percentage of Ozarkers employed in agriculture fell from 28.2 to 13.4 percent between 1950 and 1960 . The loss of opportunities on smallholder farms put

\footnotetext{
${ }^{10}$ Brooks Blevins, "Wretched and Innocent: Two Mountain Regions in the National Consciousness," Journal of Appalachian Studies 7 (Fall 2001): 266.

${ }^{11}$ Ozarks Regional Commission (ORC), Ozarks Region: An Opportunity for Growth (Washington, DC: Ozarks Regional Commission, 1967), 1-2. These figures are based upon statistics for the 125 counties in Arkansas, Missouri, and Oklahoma initially included in the Ozarks Regional Commission.

${ }^{12}$ Ann Nielson, "A Comparison of the Regional Planning Approaches of the Appalachian and Ozarks Regional Commissions" (MA thesis, University of Oklahoma, 1970), 65. In 1960, 44.4 percent of Ozarks families were deemed low income (less than $\$ 3,000$ per year), while that figure was 30.7 percent in Appalachia, as defined by the ARC.
} 
many Ozarkers on the migrant trails. During the 1950s alone, the region experienced a net loss of 431,000 people, most of them young adults who sought economic opportunities elsewhere. Consequently, older residents disproportionately populated the Ozarks. In 1960, while residents sixty-five years of age and older accounted for just over 9 percent of the national population, senior citizens made up 13 percent of the Ozarks population. ${ }^{13}$

A handful of middling backcountry folks who had not fled the region found advantages in the economic and social environment of the New Ozarks of the middle twentieth century. A few-typically those with solid connections to vital sources of capital (i.e. an exceptionally good rapport with local bankers and deemed "safe" for loan assistance by the federal government's Farmers Home Administration [FHA]) - managed to buy cheap land from neighbors as rural communities emptied and amassed farms large enough to compete in an economy dominated by Big Agriculture. ${ }^{14}$ Others secured enough capital to start small and mid-sized businesses that thrived in the industrial-, agribusiness-, and tourism-oriented political economy or found offfarm employment funded or subsidized by local, state, or federal governments.

The vast majority, however, gave up farm life altogether or attempted a part-time, "onefoot-on-the-farm strategy" to now rely primarily upon company paychecks in a low-wage, nonunion economy owned and controlled more and more by recent in-migrants and corporate business interests. A number of rural Ozarkers hung on to their family farms by converting them to "factory farms" in the employment of large agribusiness corporations, particularly poultry processing companies. In doing so, however, they were "deprived... of the independence

\footnotetext{
${ }^{13}$ ORC, Ozarks Region, 6.

${ }^{14}$ Brothers Paul and Earl Perkins of western Lawrence County were cases in point. After returning from military service in World War II, they took over the 300-acre family farm along the Strawberry River and, with the help of FHA loans, purchased neighboring farms that adjoined their property during the 1950s and 1960s. By the 1970s, they had expanded the size of their farm to more than 2,000 acres and specialized in commercial cattle raising. Bonnie Perkins interview by author, November 20, 2006.
} 
traditionally associated with Ozark agriculturists" and became "little more than temporary caretakers of the company's valuable property." "Ozarkers who were able to stay on the land in the post-World War II era had to adapt and evolve," writes one historian. "But they were a minority. Most farm families eventually left their fields and barns behind." ${ }^{15}$ Rural decline created ripe opportunities for some well-connected Sun Belt entrepreneurs like Sam Walton and Don Tyson who adeptly channeled the region's social, cultural, and political circumstances to their advantage, helping to further transform not only the Ozarks but America as a whole. ${ }^{16}$ Poverty, scant economic opportunities, and vulnerability, however, kept a dark shade over much of the region's rural heartland.

Although the region's poverty and outmigration disturbed many postwar government and agricultural officials, both locally and in Washington, they tended to view the decline in smallholder farming in the Ozarks in a positive light and helped to promote its extinction. In the post-World War II era of burgeoning national prosperity, agricultural and other government officials under the sway of powerful organizations such as the Farm Bureau and other Big Agriculture lobbies looked for ways to replace the seemingly inefficient and underproductive small-farm economies of such regions as the Ozarks. But it would be overly simplistic to suggest that high-handed federal bureaucrats imposed centralized agendas from Washington to direct the goals and policies of government farm programs in a simply top-down fashion. As historian Elizabeth Brake explains, postwar farm policies, in fact, generally worked hand-in-hand with local and regional elites' interests and plans for rural industrialization. Leaders of

\footnotetext{
${ }^{15}$ On the postwar transformation of farming in the Arkansas Ozarks, see Blevins, Hill Folks, 147-178, quotations on 168 and 178 respectively.

${ }^{16}$ Shane Hamilton, Trucking Country: The Road to America's Wal-Mart Economy (Princeton: Princeton University Press, 2008); Moreton, To Serve God and Wal-Mart, quotation on 12.
} 
agricultural programs such as the Agricultural Stabilization and Conservation Service (ASCS), the successor of the New Deal's Agricultural Adjustment Administration, exalted their organizations as "commendably democratic" and "intensely practical" by highlighting how "grassroots democracy" and local control shaped most of their programs' decision-making and administration. Brake's study, however, finds that local elites, many of whom were close partners with area banks and chambers of commerce, dominated the elections and administration of local ASCS committees and used their power to advance their industrial and agribusiness visions, as well as influence broader policymaking in Washington. ${ }^{17}$

Accordingly, the US Department of Agriculture classified 46 percent of farmland in the Ozarks within the "worst" four categories of land capability, and agricultural experts condemned small Ozark farmers' damaging and "wasteful practices," such as the plowing of hillsides and slash-and-burn grazing techniques. ${ }^{18}$ Much of family farming's history in the region, most local and federal officials believed, had largely been a mistake, at least in the modern era. The valiant and independent yeoman farmers of the nineteenth and early twentieth centuries nostalgically reminded Americans of their virtuous past in the national imagination, but small farmsteads had no place in the modern world of progress and prosperity. The solution seemed simple: the region would have to be transformed from its smallholder farming society and become more closely integrated into the national and international capitalist economy to catch up with the rest of the

\footnotetext{
${ }^{17}$ Elizabeth Brake, “'Commendably Democratic' and 'Intensely Practical'? Federal Farm Policy Administration and the County ASCS Committees," unpublished paper presented at the Southern Historical Association $77^{\text {th }}$ Annual Meeting, October 28, 2011, Baltimore, MD.

${ }^{18}$ ORC, Ozarks Region, 10; Tanner, "Echoes of Appalachia."
} 
"modernized" nation. Local, state, and federal officials advised the vast number of rural folks displaced from small farms to seek off-farm industrial work. ${ }^{19}$

In the midst of the national economy's postwar capitalist affluence, the Kennedy administration - the epitome of "corporate liberalism's" championing of growth politics over redistributive reforms to address social ills—embarked upon a mission to tear down the barriers that seemed to be preventing American prosperity from pouring into lagging areas. ${ }^{20}$ Soon after Kennedy was elected president, he established a task force to study economic conditions and develop a plan for proposing legislation to address the needs of impoverished areas. Not surprisingly, given the significance of the Democratic primary in the Mountain State, the task force was composed disproportionately of West Virginians and held its first meeting in Charleston in December 1960. Its recommendations significantly influenced the passage of the Area Redevelopment Act in May 1961. Designed to pump federal money into depressed areas left behind in America's postwar prosperity, the Area Redevelopment Administration (ARA) ascribed to a "trickle down" approach that mostly funded low-interest business loans, public facilities grants, and job training programs. ${ }^{21}$

The southern states and Appalachia received a disproportionate amount of the ARA's limited funding. ${ }^{22}$ Within these regions, however, depressed-area aid was unevenly distributed and tended to go to more urbanized and industrialized areas that needed it the least. Appalachian historians, for instance, have noted that the thinly spread ARA program did little for rural

\footnotetext{
${ }^{19}$ Brake, “'Commendably Democratic' and 'Intensely Practical'?”

${ }^{20}$ On Kennedy as the epitome of corporate liberalism, see Allen J. Matusow, The Unraveling of America: A History of Liberalism in the 1960s (New York: Harper \& Row, 1984), quotation on 33.

${ }^{21}$ Thomas, An Appalachian Reawakening, 129; Ronald D. Eller, Uneven Ground: Appalachia since 1945(Lexington: University Press of Kentucky, 2008), 57-60; David E. Whisnant, Modernizing the Mountaineer: People, Power, and Planning in Appalachia (Boone, NC: Appalachian Consortium Press, 1980), chap. 3.

${ }^{22}$ See Gregory S. Wilson, Communities Left Behind: The Area Redevelopment Administration, 1945-1965 (Knoxville: University of Tennessee Press, 2009).
} 
Appalachian communities that lacked the personnel to draft aid proposals, the required matching funds, and the profitable industrial and business prospects that were necessary for application approval. $^{23}$

The ARA had a similar impact in the Ozarks. The ARA's very first project, in fact, provided Gassville, Arkansas, a \$17,000 loan for a community industrial facility and a \$133,000 grant for a municipal water system. This funding was intended to supplement local efforts to bring in a new shirt-making factory, a subsidiary of the Capital Shirt Company of New York. ${ }^{24}$ Gassville was a small town situated within the greater Mountain Home area of Baxter County, the budding tourism, recreation, and retirement center that had undergone a major transformation since the early 1950s when the city was sandwiched between the Norfork and Bull Shoals lakes. The New York Times noted the raised eyebrows that might accompany the ARA's decision to conduct its "pilot" program of depressed-area aid in this "Resort Region." "At first glance," the Times remarked, "no outsider would guess that this tidy Ozark Mountain resort region is a depressed area and will get the first aid under the recently passed Federal assistance program.” After all, the already thriving Mountain Home area of the New Ozarks "is a hybrid of Main Street and suburbia," where "housewives in shorts gossip over coffee in Cooper's Drug Store . . [and] pastel motels and ranch houses bake in the summer sun on what was once pasture land on

\footnotetext{
${ }^{23}$ Thomas, An Appalachian Reawakening, 130-32; Whisnant, Modernizing the Mountaineer, 78-80; Eller, Uneven Ground, 60. Historian Bethany Moreton emphasizes the large doses of federal redistribution that flowed into the Ozarks - which she defines very broadly — during the post-World War II era to help transform the region into part of the Sun Belt. "In the twentieth century," she claims, ". . . communities in the South and West flourished through deliberate federal redistribution of resources out of the Northern Rust Belt into the Sun Belt ." Her focus on "WalMart Country," however, causes her to neglect the fact that these government resources were distributed very unevenly throughout the Ozarks, with few of them finding their way to the small rural communities in the heart of the region where the needs were greatest. Moreton, To Serve God and Wal-Mart: The Making of Christian Free Enterprise (Cambridge: Harvard University Press, 2009), 4-5, 24-48; quotation on 4-5.

${ }^{24}$ Wilson, Communities Left Behind, 111; Peter Braestrup, "Ozarks First to Get Depressed-Area Aid," New York Times, July 24, 1961.
} 
the fringes of town." But local elites and civic boosters convinced the ARA that the new shirt factory would provide much-needed employment opportunities for the impoverished rural hinterlands that surrounded the resort area, where the average family struggled to survive on an annual income of under $\$ 2,000 .^{25}$

The area's New Ozarks industrial boosters, led by local Ford dealer T. J. McCabe, and the Arkansas Industrial Development Commission—one of the first state development agencies of its kind in the South — had offered the shirt company numerous incentives to locate its new plant in Gassville. ${ }^{26}$ McCabe himself donated twenty acres of land to the company for the building of its new factory. Furthermore, despite spirited opposition from a group of Baxter County's "modest-income retired folk" who opposed "being taxed for the benefit of private business," local boosters in Baxter County and neighboring Marion County managed to convince voters to pass a five-mill increase on local property taxes to finance a $\$ 350,000$ bond issue to build the company a new plant facility. The shirt company would then lease the plant for $\$ 18,000$ a year for thirty-five years. Baxter and Marion counties also promised to double the size of the plant once the company employed at least six hundred workers. Company president Donald Cooper could not refuse the offer, conceding in a benevolent tone that "we wanted an area that needed us." County government officials also offered the company special tax privileges, vowed not to bring other industries into the area that might compete for the company's labor force, and promised to keep labor unions from organizing in their counties,

\footnotetext{
${ }^{25}$ Braestrup, "Ozarks First to Get Depressed-Area Aid."

${ }^{26}$ The Arkansas Industrial Development Commission (AIDC) was the second of its kind created in the South. It was established in March 1957 after North Carolina had formed the South's first state development agency in January 1956. Wilson, Communities Left Behind, 13.
} 
although the Arkansas Supreme Court struck down these latter provisions of the local bond issue. $^{27}$

The Area Redevelopment Administration's pilot project in Gassville brought disappointing results and became the source of significant controversy among national policymakers. The project promised to create about 1,200 jobs for the area, but reports in 1964 showed that employment was far below the projected level. Reports that year conflicted, with one showing employment numbers at only 500 workers and another claiming that 737 were employed at the shirt factory. Either way, the Gassville project had failed to live up to its promise. Furthermore, almost all of the factory's workers were women who were initially hired for 85 cents per hour as trainees and told that they could eventually earn up to $\$ 1.75$ an hour, though they would have to do so at piece-work pay rates. Although several poor rural women gave the new shirt factory's impact a positive appraisal—one commenting, "We wouldn't have made it last winter if it hadn't been for my working"- the fact that the ARA's pilot project helped promote low-wage employment for women ran counter to federal policymakers' priority to "create good jobs for men" and preserve traditionally gendered family economies. ${ }^{28}$ These "shortcomings" in Gassville gave the ARA's national conservative political opponents potent ammunition for their charges that the depressed-area aid program was wasting taxpayer dollars and undoubtedly disappointed many Ozarkers who had high hopes for the project. Due to the attempted anti-unionization pact between local leaders and the shirt company, the Gassville project also received major criticism from organized labor. ${ }^{29}$

\footnotetext{
${ }^{27}$ Braestrup, "Ozarks First to Get Depressed-Area Aid."

${ }^{28}$ Ibid.; Wilson, Communities Left Behind, 112; quotation on xvii.

${ }^{29}$ Wilson, Communities Left Behind, 112.
} 
It became increasingly clear to area redevelopment policymakers and supporters that the ARA was insufficient to seriously address the problems of regional poverty and underdevelopment. Governors from the Appalachian states, in particular, had already begun putting more and more pressure on President Kennedy to support more concerted regional development strategies. Arguing that underdevelopment in their region required specific multistate coordination that the thinly spread ARA could not provide, they prompted Kennedy to establish the President's Appalachian Regional Commission (PARC) in 1963. Over the next several months, PARC worked with economists and federal, state, and local agencies to discuss strategies for addressing the region's problems. Its recommendations and plans for development called for core infrastructure improvements, resource management and industrial development, flood control and hydroelectric power, and human resource development to boost economic growth. The Kennedy administration continued to move forward on an Appalachian program, but the assassination of the president on November 22, 1963, left the future of the regional agenda in question. ${ }^{30}$ Fortunately for Appalachian development proponents, Lyndon B. Johnson welcomed their regional proposal into his broader Great Society agenda. Although the Appalachian bill was largely eclipsed by Johnson's separate War on Poverty program and bounced around in the House and Senate for nearly a year, the Appalachian Regional Development Act (ARDA) finally became law on March 9, 1965, creating the Appalachian Regional Commission (ARC). ${ }^{31}$

Not surprisingly, the creation of the ARC aroused stiff criticisms from political leaders outside Appalachia. A number of them objected to giving Appalachia favored status while there

\footnotetext{
${ }^{30}$ Eller, Uneven Ground, 67-75; Whisnant, Modernizing the Mountaineer, 128-32.

${ }^{31}$ Eller, Uneven Ground, 85-86.
} 
were areas within their districts that rivaled Appalachia's poverty. The Tulsa World noted that Sen. John McClellan of Arkansas was among the loudest objectors to the Appalachian bill, since the Ozarks region of his state was in just as much need, if not more, than the eastern mountain region. McClellan and Oklahoma senator Fred Harris, who pointed to the plight of nineteen counties in the eastern part of his state, called for an amendment to have the impoverished areas in their districts included in the ARC. Congressmen and senators in New England, the Great Lakes area, and elsewhere also insisted that the impoverished locales in their regions needed special federal development programs. ${ }^{32}$

Conservative national journalist Jenkin Lloyd Jones condemned the ARC's creation and warned of "The Spreading 'Appalachia Disease"” in a February 1965 article in Human Events. "Like the hogs grunting to the trough," he wrote, "congressmen are clamoring to get their districts declared 'Appalachias." Citing a county judge in Kentucky who remarked that "you'll find about 80 percent of our people just looking for another handout," Jones asked, "Are Americans going to put on their dirtiest shirts and ragged fishing pants and go crying their deprivations and disadvantages to Washington?"33 Conservative politicians who opposed the regional program also lamented federal spending aimed to alleviate poverty in depressed regions. Responding to a constituent who apparently wondered why parts of Texas were not being included, Sen. John Tower asserted, "We should attack poverty not by creating a new taxabsorbing bureaucracy, but by encouraging creation of new jobs in private industry and business. Catchy political slogans and expensive Federal programs won't create jobs." Claiming that the Johnson administration was simply trying to dust off and revive old New Deal programs, Tower

\footnotetext{
32،"Appalachia Bill Voted,” Tulsa World, February 2, 1965.

33 Jenkin Lloyd Jones, “The Spreading ‘Appalachia’ Disease,” Human Events, February 27, 1965.
} 
quipped, "We have already tried and found wanting the CCC and the WPA and the prepetuation [sic] of tiny farms without the resources to compete. There is no reason to try these things again.” Sen. J. Caleb Boggs of Delaware likewise warned that the Appalachian program was opening the gates to "the biggest logrolling operation in history." And back in September 1964, Republican presidential candidate Barry Goldwater had denounced proposals for a regional program, along with President Johnson's other Great Society measures, as a Marxist scheme taken from the Soviet Union's playbook, a program that was altogether unnecessary, he said, since citizens in a free enterprise system always "took care of their brothers in need, but not their brothers who refused to work and wanted to live off of them." But in the Ozarks in the 1960s, hill folks expected their government to play an important role in contributing to the economic growth of their region. ${ }^{34}$

Although McClellan's and Harris's proposed amendment to add counties in northern and western Arkansas, southern Missouri, and eastern Oklahoma to the ARC was rejected in the Senate, congressional supporters of the ARC and the Johnson administration promised to include a provision for other regional commissions in a separate bill. McClellan remained suspicious and voted against the Appalachian bill, although Harris seemed content with the offer and voted for it. Indeed, the Johnson administration carried through with its promise and included a provision for other regional commissions in a new bill that would overhaul the old Area Redevelopment Administration. ${ }^{35}$

\footnotetext{
${ }^{34}$ Tower to J. W. Birkhead, May 15, 1964, Billy James Hargis Papers, box 64, folder 1, University of Arkansas Special Collections, Fayetteville; Marjorie Hunter, "Senate Opens Debate on \$1.1 Billion Appalachia Bill," New York Times, January 30, 1965; Charles Mohr, "Goldwater Derides Antipoverty Drive in Appalachia Talk," New York Times, September 19, 1964.

35 "Appalachia Bill Voted."
} 
The Public Works and Economic Development Act was passed and signed in August 1965, replacing the old Area Redevelopment Administration. Under Title V of the act, the secretary of commerce was authorized to establish multistate regional development commissions in parts of the country that lagged behind national economic norms. The Ozarks Regional Commission, created in March 1966 and officially organized in September, was the first of five Title V commissions established under the act. The designated region initially included 125 counties in northern and western Arkansas, southern Missouri, and eastern Oklahoma, although nine impoverished counties in southeastern Kansas were included in the ORC at the request of that state's governor in September 1967. Like the ARC, the ORC and the other commissions were designed as "equal" partnerships between federal and state governments, with each commission's membership comprised of a federal cochairman and the governors of the states included in the designated region, reflecting the "new federalism" that would come to characterize federal-state government relations in the late 1960s and 1970s. ORC federal cochairman William McCandless “emphasized the new, imaginative nature of the regional commission, especially its special feature of including state governors as commission members." This exceptional degree of local control, he suggested, explained why “Ozarks governors have... devoted substantial time to commission matters because they have seen in the commission a vehicle to bring about decentralization of Federal decision making." Any "excessive Federal discussion on controlling regional commissions," McCandless believed, would mean that the "commissions will not be sufficiently productive to warrant continuance.",36

\footnotetext{
${ }^{36}$ Robert T. Murphy, "The Regional Commission System,” Public Administration Review 33 (March-April 1973): 180; Nielson, "A Comparison of the Regional Planning Approaches," 37-40; Eller, Uneven Ground, 177; "Summary Minutes of the Federal Advisory Council on Regional Economic Development," April 3, 1969, General Records of
} 
There appears to have been considerable stirrings of hope among mid-American cities such as St. Louis, which saw the Ozarks as a backyard of potential future development upon the announcement of the ORC's formation in 1966. The St. Louis Post-Dispatch attempted to draw attention to the real economic plight of the rugged Ozarks that was often hidden beneath the region's tourism promotions. Most Americans_-even many of those middle-class residents who lived in the region - "are inclined to look upon the Ozarks as a fishing and boating mecca, with some neon-lighted, chromium-plated honkytonks thrown in to enliven the tourist's vacation activities," commented the Post-Dispatch. This image, unfortunately, overshadowed the fact that as many as 60 percent “of the region's young people packed their bags and left because of chronic under-employment and low incomes" during the preceding ten years. Fortunately, the St. Louis paper remarked, the new ORC “offers hope for dynamic rejuvenation of a region whose economic potential too long has been bypassed."37

Political leaders within the region also exalted the great promise that the new ORC represented. Missouri governor Warren E. Hearnes, elected by other members of the commission as the ORC's first state cochairman, helped fuel the hype when he told news reporters, "We are witnessing what might be a new era." "The vast potential of the commission," he boasted, "has raised the hope of all of us who are committed to bringing greater prosperity and a better life to the citizens of the three states." 38 Commenting on the proposed ORC when the commission's application was under consideration in December 1965, Arkansas governor Orval Faubus, the notorious defender of school segregation in the Little Rock integration crisis of 1957, assured a

the Department of Commerce (RG 40), Office of the Secretary, Executive Secretariat's Subject File, 1953-1974, box 181, National Archives, College Park, Maryland.

37 “'Ozarks’ Draining Economy,” St. Louis Post-Dispatch, August 1, 1966.

38 James C. Millstone, “3-State Board Organized to Plan Ozarks Development,” ibid., September 3, 1966;

"Statement of Governor Warren E. Hearnes, Member for Missouri of the Ozarks Regional Commission," Wilbur Mills Papers, box 431, folder 6, Hendrix College Archives and Special Collections, Conway, AR. 
Department of Commerce official, "When you and President Johnson approve our regional applications we will provide and furnish you with the most successful program in the nation." Faubus later wrote to Secretary of Commerce John T. Conner in March 1966 to say that he believed "this [ORC] program has more potentialities for bringing about greater progress and development for this economic region than any program that has been established in my lifetime. ${ }^{39}$ Along with other congressmen and senators from the region, Sen. Fred Harris of Oklahoma promised that this regional program "can make this area synonymous with 'opportunity," exclaiming, "We have always had the people, the natural resources, and the potential, and now we have the Organization to get the job done.... We have now decided to reverse the out-migration of our people and capital, high unemployment, low family income and inadequate use of our natural resources." ${ }^{40}$

Excitement about the new ORC could be seen at the local level in the Ozarks as well. Upon hearing about the new regional program, locals such as Kenneth Hurst of the small town of Evening Shade, wrote their congressmen for information about how they could benefit from the ORC's economic development activities. ${ }^{41}$ In rural Sharp County, where Hurst resided, annual per capita income was only $\$ 723$, and 60.9 percent of the population was underemployed. Hurst and others like him saw potential in the new regional program for helping to revive their decaying small towns and communities. Indeed, twenty of Arkansas's forty-four counties initially included in the ORC had populations in which more than half were underemployed, including Stone and Newton counties where, respectively, 65 and more than 70 percent were

\footnotetext{
${ }^{39}$ Ozarka Regional Development Association, board of directors' meeting minutes, December 8, 1965; Faubus to Conner, March 4, 1966, both in Mills Papers, box 431, folder 7.

${ }^{40}$ Ozarks Regional Development Association, board of directors' meeting minutes.

${ }^{41}$ Hurst to Wilbur Mills, September 7, 1967, Mills Papers, box 431, folder 3.
} 
underemployed. ${ }^{42}$ The new ORC seemed to offer hope amid increasingly grim prospects for rural folks in the New Ozarks.

In Perry County, where underemployment stood at nearly 60 percent in 1960, a high school civics teacher, Mr. Neal, asked his ninth-grade students at East Bigelow High School to consider the recent news of the ORC's creation and what it might mean for their rural community. They were then to write letters to Rep. Wilbur Mills expressing their and their families' opinions of the regional program. All of the students concurred with Judy Dickens who, although she admitted that she did not know much about the details of the program, wrote that she and her family believed "it will mean a great deal to my county and town." Specifically, since her town's 237 residents “need[ed] a sewage system badly," Dickens and her family hoped that "the Ozarka program will enable my town and others to have the facilities we need."43

Ninth-grader Joyce and her family likewise believed that the regional program was a "very good and intelligent thing." But they also expressed doubts about the fairness of the ORC's future activities since "it looks like Missouri and Oklahoma are going to get the best part of the deal." Joyce and her family insisted that ORC projects "should be divided equal between the states." ${ }^{44}$ Many of the region's political and business elites, such as Mayor Jan M. Bullock of Eureka Springs, also expressed concerns about the ORC's fairness. Bullock shared the suspicions of Arkansas's State Planning Commission, which was "gravely concerned that the State of Oklahoma expects to receive the vast majority of the $\$ 3,000,000$ planning fund." The mayor proposed instead "that the vast majority of the planning funds need to be expended in

\footnotetext{
${ }^{42}$ ORC, “Ozarks Regional Commission-Economic Facts,” n.d., ibid., box 431, folder 1.

${ }^{43}$ Dickens to Mills, October 8, 1966, ibid., box 431, folder 5; ORC, "Ozarks Regional Commission-Economic Facts."

${ }^{44}$ Dickens to Mills.
} 
Northwest Arkansas on the planning of new highways and other public facilities feasible under this program" because eastern Oklahoma had already received large amounts of federal aid for highway building through other programs in recent years. ${ }^{45}$ Despite such concerns, and perhaps in light of them, Ozarkers appear to have seen important potential in the regional program as long as their areas received a fair share of the development funding.

It did not take long, however, to realize that the ORC was strapped with major limitations. Just as funding issues were being worked out for the new regional commission, the Johnson administration and the Office of Emergency Planning (OEP) announced concerns about growing inflation and asked federal agencies and state governments to limit spending on construction and development projects that might add to the problem, in addition to asking American businesses to reconsider investment plans and housewives to practice wise consumption. In April 1966 Arkansas governor Orval Faubus publicly objected to the administration's anti-inflation policies, arguing "that this has stymied the three-state Ozarka Regional development program" just as it was getting off the ground. The OEP assured the regional commissions that funding applications would still be considered as usual, but Faubus and other members of the regional commissions saw the logical consequences that the administration's anti-inflation worries posed for the young regional development programs and began blaming federal bureaucrats in Washington for the problems. ${ }^{46}$

The new ORC's timing proved a major impediment amid the United States's escalating war in Vietnam. President Johnson himself regretfully described the war's detrimental impact on

\footnotetext{
${ }^{45}$ Bullock to Wilbur Mills, June 11, 1965, Mills Papers, box 431, folder 7.

46 “U.S. Disputes Faubus' Thinking on Ozarka,” unknown newspaper clipping, April 16, 1966, News Clippings: Ozarks Regional Commission, Center for Ozarks Studies Records, box 8, folder 28, Missouri State University Special Collections, Springfield.
} 
his broader domestic agenda: "I left the woman I really loved—-the Great Society—in order to get involved with that bitch of a war on the other side of the world. ${ }^{477}$ As the demands of the war and heightened conservative criticism took their toll on practically all Great Society programs, the new Title $\mathrm{V}$ regional commissions received an especially hard hit, since the programs just getting started were easier to put on the back burner when competition over funding and resources increased. Just as news of the new regional commission had stirred optimism about the potential to bring widespread prosperity to the Ozarks, disappointed ORC officials were left to explain the federal budget problems to hopeful constituents. When Rep. Wilbur Mills wrote to ORC federal cochairman William McCandless in October 1967 on behalf of a constituent who had inquired about the program's opportunities for his rural community, McCandless had to reply that the ORC "has not received at this date any money with which to fund specific projects, and the realities of the war in Vietnam and the pressure on the federal budget would suggest that we cannot expect any substantial appropriation by the Congress until these two conditions have changed."

The early disappointment in the Ozarks Regional Commission was perhaps best expressed by an unknown staff member of Arkansas's new governor, Winthrop Rockefeller- the state's first Republican governor since Reconstruction—in $1967 .{ }^{49}$ Upon entering the governor's

\footnotetext{
${ }^{47}$ Johnson quoted in H. W. Brands, The Strange Death of American Liberalism (New Haven, CT: Yale University Press, 2001), 97.

${ }^{48}$ McCandless to Mills, October 10, 1967, Mills Papers, box 431, folder 3.

${ }^{49}$ Rockefeller's political ascendancy in Arkansas was an anomaly in the broader crumbling of the Democratic Party's virtual monopoly in the Solid South and the rise of the Republican Party in the old Confederacy during the 1960s. Most historians point to whites' resentment of the black civil rights movement as the key to the Republican Party's rise in other southern states, but Rockefeller's "belief in racial equality became well-known" in Arkansas and he defied a number of the conservative, limited-government principles among many leading voices of the national GOP's establishment by calling for higher taxes and government assistance to promote economic growth and educational improvement. The wealthy, New York-born grandson of John D. Rockefeller had headed the state government's new Arkansas Industrial Development Commission during Governor Faubus's administration and he made economic development the centerpiece of his gubernatorial campaign in 1966. His success at the polls reveals
} 
mansion, Rockefeller received a briefing on the ORC's administration and goals and was advised to "cover 'Local Expectations' with McCandless," the federal cochairman in Washington. "This program has been badly oversold on the local level," the staff member wrote. "There will probably never be the money from Congress that has been envisioned; at least not in the foreseeable future." It was suggested that Rockefeller "put the burden on McCandless [and other Washington bureaucrats] to bring local expectations more in line with reality., 50

Budget problems were, in fact, compounded by the Title V commissions' bureaucratic organizational structure. Unlike the Appalachia Regional Commission, which held an independent status within the Executive Office of the President, the ORC and other Title V commissions were given a "stepchild status" under the Department of Commerce. ${ }^{51}$ While the ARC reported directly to the president, enjoyed direct lines to the Office of Management and Budget, and was authorized to both set regional development policy and directly fund its projects, the ORC and the other commissions merely served in a planning and advisory capacity and answered to the secretary of commerce. Initially, the ORC's funding could only be used for research, planning, and administrative costs, though Congress passed an amendment in 1967 that allowed the Title $\mathrm{V}$ commissions to issue small supplemental grants (usually no more than 20 percent of total costs) for projects in which state and local governments could not come up with all of the matching funds required for grants from the Economic Development Administration, the Farmers Home Administration, the Federal Aviation Administration, and other federal

the hope among Arkansas voters in the potential for new economic development to bring widespread prosperity and lift all boats in the state. Tom W. Dillard, "Winthrop Rockefeller (1912-1973)," Encyclopedia of Arkansas History and Culture (http://www.encyclopediaofarkansas.net/encyclopedia/entry-detail.aspx?entryID=122).

50 "Briefing on the Ozarks Regional Planning Commission," Winthrop Rockefeller Papers, box 92, file 2b, University of Arkansas at Little Rock Special Collections, Butler Center for Arkansas Studies, Little Rock.

${ }^{51}$ Leland P. Gordon Jr., "The Ozarks Regional Commission and Its Impact in Arkansas" (graduate internship paper, University of Arkansas, 1973), 11. 
agencies. The Title V commissions' status within the Department of Commerce meant that they collectively competed, along with the department's other agencies and projects, against the ARC for funding. And, as one observer put it, all of the ORC's "recommendations must be sent through bureaucratic channels for approval before they can be implemented." 52

This secondary status frustrated regional commission officials and their member states who felt entitled to a larger slice of the government's development pie. In February 1969 senators representing the Title V commissions confronted the Senate Public Works Committee chairman Jennings Randolph of West Virginia and other leaders and sponsors of the ARC about the seeming unfairness of the other regions' secondary status and the favoritism shown to Appalachia in funding. Randolph justified the ARC's preeminent position by arguing that its domain served nearly the same number of people, approximately sixteen million, as the other regional commissions combined. More importantly, however, Randolph argued that the older and more experienced Appalachian program was intended to serve as the pilot project for the other regions. Sympathizing with the distressed conditions of the other regions, Randolph claimed, "Our [ARC's] experiences will help them. The few errors that we have committed in part will be their successes." The senator vowed to continue supporting the other regional commissions, but he was unwilling to relinquish Appalachia's favored status in the federal government's regional development policy. ${ }^{53}$

\footnotetext{
${ }_{53}^{52}$ Ibid., 11-12; Nielson, "A Comparison of the Regional Planning Approaches," 66.

${ }^{53}$ Congressional Record, S1776 (February 18, 1969). The other depressed regions found little encouragement in Randolph's explanations and continued to lament the restrictions upon their commissions. Indeed, Randolph's argument about the ARC's higher population could not withstand the fact that the Title V commissions' funding paled in comparison to that of the ARC in terms of per capita spending. While Congress had authorized over $\$ 3$ billion and spent over $\$ 1.6$ billion (over 52 percent of the authorization) on the ARC by 1973, it had authorized only $\$ 950$ million and spent only $\$ 140.6$ million (less than 15 percent of the authorization) on the five Title $\mathrm{V}$ commissions combined. Even considering the Appalachian program's higher population, the ARC received \$75.22
} 
Commission officials and the state governors and local supporters in the region all agreed that the program had great potential but was simply too limited to live up to its promise. Missouri governor Warren E. Hearnes praised the thoughtful planning and limited work the commission had been able to accomplish, claiming that several development projects would have failed if not for ORC support. But he told reporters "that if the commission program is ever to become effective," it would have to be freed from its bureaucratic position under the Department of Commerce because "funds from that department alone cannot carry the commissions." 54 Arkansas's new Democratic governor in the early 1970s, Dale Bumpers, issued a more stinging appraisal of the commission's organization, calling it a "cruel hoax" because it had given Ozarkers false hopes that it would transform the region's economy. Testifying before a Senate subcommittee in 1972, Bumpers demanded that the ORC and other Title V commissions be either restructured as independent agencies equal to the ARC or at least given higher status within the Department of Commerce. "If we are going to meet even the basic needs," urged Bumpers, "we must make the same billion dollar effort that has been made in Appalachia." One federal official claimed, however, that, despite the exceptional level of shared power that already existed in the program, what the governors really wanted was "to minimize the role of Commerce, keep the Federal Cochairman out of their hair in Washington, dominate the

to spend per resident in 1973 while each of the other five regional commissions' funding represented only $\$ 7.77$ per resident. Gordon, "Ozarks Regional Commission," 10-11.

${ }^{54}$ Ibid, 63-64; "Hearnes Urges Support for Ozark Region Unit," unknown newspaper clipping, December 3, 1970 , News Clippings: Ozarks Regional Commission, Center for Ozarks Studies Records, box 8, folder 28.

${ }^{55}$ Douglas W. Cray, "Regional Uncertainty: U.S. Trims Economic Programs in Budget," New York Times, April 8, 1973; Gordon, "Ozarks Regional Commission," 11-12. 
Executive Director on the scene, thus hopefully capturing the Commission staff for themselves. They also want more money that they can control. ${ }^{.56}$

By the early 1970s, however, the regional commissions and their supporters found themselves merely trying to survive under Pres. Richard Nixon's hostile administration. Nixon had proposed that the commissions be phased out and their funding integrated into his broader revenue-sharing program in which he issued federal block grants to individual states and cities. But the Senate voted seventy-seven to three in March 1971 to extend the regional federal aid program, an outcome that one political observer called Nixon's "first legislative setback." Republican defenders of the regional program, such as ARC supporter Howard Baker Jr. of Tennessee, argued that the commissions, in fact, could work hand-in-hand with Nixon's new revenue-sharing plan. Nixon came to accept the continuation of the thirteen-state ARC, which was backed by several of his strongest supporters, but his administration continued its efforts to eliminate the Title $\mathrm{V}$ commissions. The president dropped all funding for the commissions in his 1973 budget proposal, although there was "a change in the White House viewpoint" when legislators from the other distressed regions lashed out at the unfairness of Nixon's support for the ARC. ${ }^{57}$

Furthermore, by the mid-1970s the ORC had decided to include entire states, instead of just its underdeveloped Ozarks counties, within its domain, a move that ultimately fit better with Nixon's federal revenue-sharing plan with the states. Before, state governors often found

\footnotetext{
${ }^{56}$ Ralph Mecham to Maurice Stans, May 27, 1969, General Records of the Department of Commerce (RG 40), Office of the Secretary, Executive Secretariat's Subject File, 1953-1974, box 181, National Archives, College Park. ${ }^{57}$ Gordon, "Ozarks Regional Commission," 11-12; John W. Finney, "Senate, 77-3, Votes to Keep Project to Aid Appalachia," New York Times, March 12, 1971; "Projects in Ozarks Taper Off," St. Louis Post-Dispatch, April 1, 1973; "U.S. Funds are Cut Off for Ozark Commission," ibid., February 14, 1973; "Ozarks Commission Dropped from Budget," unknown newspaper clipping, January 31, 1973, News Clippings: Ozarks Regional Commission, Center for Ozarks Studies Records, box 8, folder 28.
} 
themselves in the uncomfortable position with their constituents of favoring certain counties and found it politically advantageous to call for the inclusion of their entire respective states. By 1974 the ORC's boundaries had greatly expanded beyond the 125 counties in southern Missouri, northern and western Arkansas, and eastern Oklahoma that were originally designated in 1966 to now include the entire states of Arkansas, Missouri, Oklahoma, Kansas, and Louisiana. Like the ARC, which had also earlier enlarged its boundaries to obtain wider political support, the expansion of the ORC's borders spread already meager resources even thinner and essentially undermined any remaining hopes for regional development in the true geographic Ozarks. The decision to include entire states did, however, help keep the commission temporarily alive by giving more political constituencies a stake in the program. ${ }^{58}$

From at least 1972 on, when President Nixon vetoed an amendment that would have given Title $\mathrm{V}$ commissions more autonomy and authorization to fund regional development projects beyond their supplemental grants, high hopes that the ORC would pump new life into the region's economy mostly dissipated as the commission and its supporters struggled just to survive. ${ }^{59}$ The regional program would fare a little better under the Jimmy Carter administration, but it seemed to most observers that the ORC and the other Title V commissions were just "part of the price for winning Senate support for the Appalachian program," as New York Times journalist John W. Finney put it. ${ }^{60}$ Feelings of disappointment in the Ozarks, meanwhile, increasingly lent a popular air of credibility to many frustrated regional and local elites' fiery

\footnotetext{
${ }^{58}$ ORC, Ozarks Regional Commission Economic Development Action Plan (Washington, DC: Ozarks Regional Commission, 1976), ii; Ronald D. Eller, "Modernization, 1940-2000," in High Mountains Rising: Appalachia in Time and Place, ed. Richard A. Straw and H. Tyler Blethen (Urbana: University of Illinois Press, 2004), 214. On the "true geographic Ozarks region," see geographer Milton D. Rafferty's definition in Rafferty, The Ozarks: Land and Life, xiv, 2-3, 12-13.

${ }^{59}$ Gordon, "Ozarks Regional Commission," 64-65.

${ }^{60}$ Finney, "Senate, 77-3, Votes to Keep Project to Aid Appalachia."
} 
charges that "limousine liberals" and Big Government bureaucrats' were inherently guilty of mismanagement and favoritism toward "special interests."

State and regional ORC officials and their supporters were, perhaps, at least partially justified in criticizing the commission's organizational and funding restrictions as key reasons for the program's inability to fulfill its promises. Like much of the American liberal state's ambitious domestic social agenda in the 1960s, the ORC and other development programs had declared war to eradicate poverty but never obtained enough federal resources and commitment to carry out a full-scale fight. Local and regional officials' tendency to place full-blame for the program's shortcomings on the blunders of the federal government, however, neglected their own role in the program's disappointing effects. An examination of regional leaders' planning activities and the projects for which the ORC provided its limited supplemental grants suggests that a stronger and better-funded regional program would likely have only further promoted uneven economic development in the region, much like that promoted by the better-funded and organized ARC in its region. With the Ozarks commission modeled almost exclusively on an industrial-development approach, state and local leaders maintained constricted visions about how to address rural economic problems, namely their unshakable faith in the growth politics that shaped the political economy of the post-World War II era. The story of federal regional economic policy in the Ozarks, like that of Appalachia, reveals that, in the words of historian Ronald D. Eller, "The development process is a value-laden political act, complete with winners and losers. ${ }^{, 61}$

Upon first hearing about the new ORC, a few rural folks hoped the program might help them revive a viable smallholder farm economy in their communities. "As we understand [it],"

${ }^{61}$ Eller, Uneven Ground, 7. 
E.A. Emerson of Van Buren County wrote Governor Faubus, "the [regional development] idea should originate at the 'grassroots' of the local area." Thus, Emerson, who spoke on behalf of a newly-formed rural "Steering Committee" in his home area, proposed a three-step plan that might provide "the means for the development of an economy for this area that can be permanent and self sustaining." First, the new regional commission would conduct an "intensive survey of agricultural possibilities" that best suited particular areas and establish plans for "specific development projects." Then, the ORC would begin "building...warehouse[s], Processing plants, [and] Freezing plants" and assist with "Road development," "Power development," and other projects to upgrade the region's infrastructure. The commission's new federallyconstructed and -owned agricultural facilities would be "leased or rented to private companies" at rates that would eventually raise enough revenue to repay project costs, administer the programs, and even provide agricultural education and other services for local farmers. Finally, the commission, which would establish a "central advisatory [sic] office" and several "suboffices" throughout the region, would be charged with "Finding markets, Obtaining price information, advertising commodities...[and] Working with state and national governmental agencies" to secure grants and other funding and develop and execute planning initiatives to promote smallholder hill farming. Ultimately, Emerson believed this was "something that will provide future jobs at home, here, and overcome the need for these people to have to search for part time jobs...or, the more aggressive, the necessity to leave the state permanently in order to secure a reasonable livelihood., ${ }^{, 62}$

\footnotetext{
${ }^{62}$ E.A. Emerson to Orval Faubus, November 29, 1965 and E.A. Emerson to Orval Faubus, December 6, 1965, Faubus Papers, box 481, folder 3, University of Arkansas Special Collections, Fayetteville.
} 
Ozarks Regional Commission officials and most of their local development supporters made it clear from the start, however, that their aim was to transform the region's small-farm economy into a thriving "modern" industrial one. Commenting on the region's historically rural, small farm orientation, the ORC asserted in its first published mission statement in 1967, "The Ozarks Region, still with a substantial percentage of its people living on farms or in rural nonfarm communities, must make even greater economic development advances than other areas to achieve a healthy economy." "This is not being done now," the statement continued," and it cannot be done by relying on the traditional ways of making a living in the Ozarks, such as agriculture. ${ }^{63}$

Boosters in the region especially held up the Ozarks' "unique" labor advantages for prospective industries and employers who might locate in the area and begin transforming the economy. "Accustomed to eking out a living from worn-out farm land," Tanner noted in his 1965 Wall Street Journal article, “[Ozarkers] know the value of a job and don't treat one lightly." Tanner pointed to companies like Daisy, an air-rifle manufacturer, that had seen the advantages in the region's labor force and decided to relocate their plants. Daisy's president claimed that he moved his company from Michigan to Rogers in northwestern Arkansas because he wanted to establish his company in a place "where people were interested in doing a day's work for a day's pay." Importantly, Daisy had successfully resisted five efforts by unions to organize its Arkansas plant. ${ }^{64}$

Regional developers were convinced that federal aid could be used to provide the necessary incentives that would attract more industries and companies into the region. Governor

\footnotetext{
${ }^{63}$ ORC, Ozarks Region, 7.

${ }^{64}$ Tanner, "Echoes of Appalachia."
} 
Faubus, believing "that the first thing to do is development work down to the grassroots," had initially argued during the ORC's early startup phase that the program's primary objective should be highway building and basic infrastructure improvements. But as regional leaders and US Secretary of Commerce Maurice Stans hashed out the ambiguous meaning of "economic development" in 1969, they decided that "we should switch the emphasis from the current infrastructure Public Works approach that has been followed by ... the Commissions to development of jobs in the private sector." Stans, agreeing with the sentiments of most state governors and regional commission supporters, argued against an emphasis on "providing roads, schools, utilities, etc." since "the thrust should be upon reaching potential employers and persuading them to come in." Once they entered the region, he claimed, in the typical language of supply-side economics, "the streets and schools will follow." Stans concluded: "Economic development' means the expansion of income-producing activity, aimed at growth in output and in income and employment. It is not ... oriented toward upgrading the general welfare of the region." Instead of worrying so much about "lagging areas" that might have no hope for revitalization to begin with, furthermore, the regional commissions should prioritize "the bird in the hand" and focus on those better-off areas with the greatest potential for growth. ${ }^{65}$

Most commission members, including Governor Winthrop Rockefeller, promoted what became known as the "growth center strategy" as the only viable course for sound regional development, which required that emphasis be placed on "natural" centers that promised high levels of growth and good returns on public investment. During his gubernatorial campaign in October 1966, Rockefeller issued his plan for regional development in which he argued that

\footnotetext{
${ }^{65}$ Ralph Mecham to Maurice Stans, October 20, 1969; "Minutes of the [Commerce] Secretary's Conference on the Regional Economic Program," June 20-21, 1969, General Records of the Department of Commerce (RG 40), Office of the Secretary, Executive Secretariat's Subject File, 1953-74, box 181, National Archives, College Park, MD.
} 
there were fourteen "natural" subregions within Arkansas. Each of these subregions, he suggested, contained "capital cities" where development efforts should be directed because economic prosperity, it was assumed, would radiate outward into the opportunity-strapped hinterlands. ${ }^{66}$

The ORC's emphasis on growth centers, despite its much more limited funding, helped produce results that mirrored the path of economic development in Appalachia. Historian Ronald Eller's study of the ARC explains, in fact, that that "commission's growth center strategy ... exacerbated the poverty and depopulation of rural areas." ${ }^{\prime 67}$ Ironically, although the federal government's regional aid program had been "sold" and justified by highlighting the severe poverty of rural underdevelopment, the growth center strategy ensured that most projects ignored the areas that needed assistance the most. To be sure, ORC planning and supplemental grants for such projects as hospitals and vocational and technical colleges (many of which have now become important community colleges in the region) provided much-needed aid for health care and education in the Ozarks. These were benefits that generally reached beyond the growth centers where the facilities were located, although in the case of vocational and technical education, Ozarkers frequently stepped from these schools into poor and low-wage job markets and wound up leaving the region in order to put their newly acquired skills to work. "The jobs are not out there," one disillusioned agency director remarked. "What good is it to sit here and train our people for its own sake?"68 In general, most development projects failed to live up to

\footnotetext{
${ }^{66}$ Morley to Faubus; minutes, September 7, 1966; Winthrop Rockefeller, "Regional Planning for Economic Development," Rockefeller Papers, box 36, file 1.

${ }^{67}$ Eller, Uneven Ground, 192-93.

${ }^{68}$ Bob Adkisson quoted in Marvin Schwartz, In Service to America: A History of VISTA in Arkansas, $1965-1985$ (Fayetteville: University of Arkansas Press, 1988), 108.
} 
the promise that benefits would radiate outward from growth centers to uplift the whole regionrural hinterlands and all.

Between 1968 and 1979, the Ozarks Regional Commission spent \$69,647,418 on 660 supplemental grants. Of these, 424 went to industrial parks and industrial water and sewer systems, 92 to vocational and technical schools, 49 to small airports, 43 to industrial access roads and railroad spurs, 34 to community facilities projects, 9 to hospitals, and 9 to port facilities. ${ }^{69}$ Many of the commission's projects in the Arkansas Ozarks benefited the already prosperous Springfield Plain subregion in extreme northwestern Arkansas, the home of that state's flagship university and the birthplace of Fortune 500 companies such as Wal-Mart, Tyson Foods, and J. B. Hunt Trucking, and several others went to resort and recreational areas near man-made lakes. Most of the poorest and least developed areas in the region, however, including Fulton, Sharp, Searcy, Stone, and Newton counties - the latter, of course, was the primary subject of Tanner's 1965 Wall Street Journal article_-received no supplemental grants at all. As was the case in Appalachia, federal regional development resources in the Ozarks were designed "to flow to more populous and politically powerful counties."70

A number of residents of poorer small towns and communities in the rural Ozarks grew more and more frustrated at the difficulties in obtaining assistance for even the most basic needs, while larger towns and cities secured federal funds. W.R. Braden of the rural Muddy Gap community complained early on about the ORC's neglect of small rural communities to Governor Faubus, a fellow Madison County son, explaining that it appeared to him and many of

\footnotetext{
${ }^{69}$ Ozarks Regional Commission Listing: Technical Assistance Projects, Demonstration Projects, Supplemental Grant Projects Completed or in Progress, FY 1968-FY 1979, n.d., n.p. (available at John Vaughan Library, Northeastern Oklahoma State University, Tahlequah), 2.

${ }^{70}$ Gordon, “Ozarks Regional Commission," 33, 50; Blevins, Hill Folks, 213; Ozarks Regional Commission Listing, 2-10; Eller, "Modernization," 215.
} 
his rural neighbors that "most of the Ozarks plan money will be spent a long ways from the Ozarks and in heavy populated [and] prosperous areas to get votes.” Braden, a Mountain Republican, warned Faubus that "unless you plan to spend the money in the Ozarks your days as the governor is fast ceasing." ${ }^{71}$ In December 1975 Sen. John McClellan of Arkansas wrote Secretary of Commerce Rogers Morton to get answers for "some of the tough questions which have been addressed to me" by rural constituents on why many of Arkansas's most distressed areas were being ignored in economic development assistance. "The decisions ... have resulted in raising false hopes about assistance which might be available," he wrote, "and have contributed to the credibility problem which all of us in public service must deal with constantly." Despite these qualms and others, the growth-center strategy remained at the center of regional development efforts, and local and regional political leaders passed the buck to federal officials in Washington to bear the complaints of disappointed rural folks. ${ }^{72}$

Most of the ORC's planning studies, advising, and supplemental grants, in fact, were implemented locally through the Economic Development Administration's (EDA) area development districts, which were run by multicounty boards generally comprising county judges and commissioners, town mayors, and heads of local chambers of commerce. ${ }^{73}$ These local planning districts and the local officials controlling them usually garnered most of the credit and praise for development efforts that seemed to succeed. The town of Harrison in

\footnotetext{
${ }^{71}$ W.R. Braden to Orval Faubus, March 7, 1966, Faubus Papers, series 13, subseries 3, box 481, folder 5, University of Arkansas Special Collections, Fayetteville.

${ }^{72}$ McClellan to Morton, December 2, 1975, Records of the Department of Commerce (RG 40), Annual Reports of the Commission Ozark, 1974-1980, box 1, National Archives, College Park, MD.

${ }^{73}$ The Department of Commerce's Economic Development Administration was also created by the Public Works and Economic Development Act of 1965 to replace the old Area Redevelopment Administration and become the centerpiece of the federal government's new economic development program. Though the EDA and the Title V regional commissions were technically separate programs, they often worked together closely on development projects.
} 
Boone County — the designated growth center for its subregion—even made national news in a 1973 New York Times article for its "striking" economic progress amid the rural "razorback ridges of the Ozarks." Failing to even mention an $\$ 89,400$ supplemental grant from the ORC for the development of an industrial park in the town in 1970 and other forms of federal assistance, the article, drawing from interviews with local officials and businessmen, attributed the town's "turn-around" to the local chamber of commerce, entrepreneurs, and county development leaders, claiming that the town had "pulled itself back from ... stagnation and decline.,"74

On the other hand, local elites and officials tended to deride the broader scheme of federal regional development when proposals emerged that threatened their local control. The experience of Ozark County, Missouri-located just across the Arkansas line—is a case in point. County commissioners there were initially reluctant to join the seven-county EDA planning district and leery of the regional program, probably feeling subordinated to the subregion's growth center at West Plains, Missouri. Nonetheless, they hoped to be able to use the district to bring valuable federal funding to their county. Indeed, Ozark County was able to secure an EDA grant to purchase two much-needed ambulances after new state regulations prevented a local funeral home from continuing to provide ambulance services, and the county also received funding through the EDA to run water lines to industrial sites in the county-seat town. Ozark County also received a $\$ 51,600$ supplemental grant from the ORC in 1971 to help build an industrial park in Gainesville. But county officials, realizing their subordinate position as a nongrowth center, became highly suspicious about the broader regional program and the seeming threat that it might eventually pose to their control over local affairs. Ozark County officials

\footnotetext{
${ }^{74}$ Wayne King, “A Small Town: Arkansas Area Pulls Itself Up From Stagnation,” New York Times, December 16, 1973; Gordon, "Ozarks Regional Commission," 50; Ozarks Regional Commission Listing, 3.
} 
attended only one ORC meeting and refused to participate thereafter, and they even withdrew from the local seven-county EDA planning district in 1974, claiming that its local citizenry "would lose its authority in a seven-county bureaucracy and that land control, at some time or other, would be implemented through the commission [ORC].,75

The growth center strategy also spawned conflict between local leaders who vied for "capital"-center status in their subregions, realizing that most development funding would be funneled into those places receiving that designation. Town booster and businessman Thomas Tinnon of Mountain Home in Baxter County wrote EDA field coordinator John Opitz in March 1967 to demand a realignment of the local multicounty planning districts so that his town could have its rightful place as a subregional growth center. Complaining that federal officials had wrongly placed his town and county in the easternmost part of a planning district centered at Harrison in Boone County, Tinnon insisted that it was only logical to redraw the lines and create his proposed alternative district with Mountain Home at its center, citing common socioeconomic and political factors, the fact that his town was a center of employment, and shared interests in facilitating tourism. "By any criteria," he wrote, "Mountain Home, Arkansas should be designated an Economic Center ... for the purpose of planning and developing the economy around common interests for the common welfare of all concerned." ${ }^{, 76}$ Though he insisted that his proposal was "for the common welfare of all concerned," Tinnon fully understood the implications of a growth center strategy that would mostly reward Harrison with federal dollars at Mountain Home's expense. Faced with such frustrating dilemmas, local

\footnotetext{
${ }^{75}$ Ruby Robins, "Nine Decades of Progress: 1900-1991," in A History of Ozark County, 1841-1991, ed. Shirley Carter Piland (Gainesville, MO: Ozark County Genealogical and Historical Society, 1991), 30-31, quotation on 31; Ozarks Regional Commission Listing, 23.

${ }^{76}$ Tinnon to Opitz, March 15, 1967, Mills Papers, box 431, folder 5.
} 
leaders typically lambasted a "stubborn" and "out-of-touch" bureaucracy in Washington for their and their constituents' problems.

The problem of further encouraging uneven development grew even more when the Ozarks Regional Commission added entire states by the mid-1970s. Though Nixon's revenuesharing plan encouraged this approach among the regional commissions, state officials were the most vocal advocates for including entire states within their borders, especially since "governors find themselves in the difficult position of pleading the special interest of [certain] counties." Some federal officials, including EDA field office director John Opitz, warned that expanding the commission's boundaries would necessarily require increased funding and personnel if it hoped to fulfill its mission, funding that Congress and the administration almost certainly would not approve. ${ }^{77}$ The governors and other state and regional officials determined to expand the ORC's borders, nevertheless. By January 1969 metropolitan developers in large cities outside the region were also pitching arguments that their cities should be included within the ORC's boundaries since "it would be beneficial if the Commission could tie St. Louis and Kansas City to the hinterlands of the metropolitan areas" and produce "more bang for the buck" on public investments. Other Title V commission members, particularly from the Upper Great Lakes commission, objected to including large metropolises such as Detroit, arguing that such an approach defeated the whole principle of providing aid to depressed regions, but Ozarks

\footnotetext{
${ }^{77}$ ORC meeting minutes, December 23, 1968, General Records of the Department of Commerce (RG 40), Office of Federal Cochairmen-Ozarks Regional Commission, Organization Meetings and Policy, 1966-69, box 2, National Archives, College Park, MD.
} 
governors' calls to include entire states became the norm in federal regionalism by the mid1970s. ${ }^{78}$

By the mid-to-late-1970s, despite the ORC's obvious limitations and the failure of the federal government's regional aid program to live up to the promises that had been made when it began, the commission still had some supporters within the region, mainly chamber-ofcommerce types in larger urban centers. J. William Perry, the president of the Little Rock Chamber of Commerce, for instance, complimented the ORC, claiming, "I do not know of a 'better run' agency and an agency that does more for our region." Similarly, in January 1981 the enthusiastic chairman of the board of a Little Rock-based advertising and business consulting agency wrote the ORC federal cochairman: "Keep the faith, baby. . . Ronnie needs all of the growth centers he can get out here in the boon docks!... . Stimulating private-sector growth has got to be his 1981 theme song! We just need to keep the growth music flowing. ... It's an economic fox-trot we're after!"79 Ironically, President "Ronnie" Reagan's decision that same year to terminate the ORC along with his other social spending cuts in the name of promoting private sector growth may have caught this pro-growth economic booster off guard. He had apparently found appealing Reagan's political ideology and campaign promise to shrink government but seems to have expected important exceptions.

Such compliments on the ORC from the rural hinterlands of the region - those that had been held up in the mid-1960s as examples of the great needs that the government's regional

\footnotetext{
78 "Summary Minutes of the Federal Advisory Council on Regional Economic Development,” April 3, 1969; Ozarks Regional Commission, meeting minutes, January 7, 1969, General Records of the Department of Commerce (RG 40), Office of Federal Cochairman Ozarks Regional Commission, Organization Meetings and Policy, 1966-69, box 2, National Archives, College Park, MD.

${ }^{79}$ Harley W. Ladd to Iuen, October 2, 1975; Perry to Iuen, February 3, 1981; Al Pollard to Iuen, February 2, 1981, all in Records of the Department of Commerce (RG 40), Annual Reports of the Commission Ozark, 1974-1980, box 2.
} 
program would address - were few and far between, however. Indeed, by the late 1970s, the ORC came under stinging criticism in some rural areas and towns. After the ORC published its annual report in the spring of 1979, the small-town newspaper editor in Iola, Kansas, published an article titled "Expensive Vanity" that blasted the federal government's "conspicuous waste of the taxpayers' dollars ... [for its] overblown, expensive annual report which will never be seen by the public the commission was created to serve." The paper was especially critical of the fancy, high-quality pictures that appeared on ten of the report's twenty-four pages when a basic, inexpensive "summary report" issued on standard typewritter paper would have sufficed. "Such a utilitarian, economical approach would never do, however, because an opportunity to puff up the ORC staff and the elected officials would go unseized," it continued. "It is a small matter. Only a few thousands of dollars were wasted," the paper admitted. "But it is another example of government for the sake of government rather than government with the public in mind." Many of the paper's rural readers undoubtedly nodded their heads in agreement. ${ }^{80}$

When a copy of the Iola newspaper article reached the desk of one ORC staff member a few days later, he cussedly scribbled in the margins, "You can't win an ass-kicking contest with a skunk!" But most rural Ozarkers had experienced little but disappointment from the government's regional program that had promised to bring economic salvation to their distressed communities. ${ }^{81}$ The regional commission, especially for the poor and middling rural Ozarkers it was designed to serve, had mostly been the "cruel hoax" that Arkansas governor Dale Bumpers described, and its limited planning and programs had only further contributed to the uneven economic development that already characterized the region. Thus, when Ronald Reagan

\footnotetext{
80 “Expensive Vanity," Iola (KS) Register, May 4, 1979.

81 "Expensive Vanity," photocopy, Records of the Department of Commerce, Annual Reports of the Commission Ozark, 1974-1980, box 2.
} 
entered the White House with his budget-cutting axe in 1981, bent on slashing government social spending and lowering taxes, it is doubtful that many Ozarkers suffered heartaches when he felled the ORC.

Nevertheless, faith in industrial development never wavered in the Ozarks. The ORC disappointed Ozarkers primarily because more and more of them had come to believe that it was bumbling and faceless bureaucracy in Washington that kept their region tethered to poverty and underdevelopment and deprived them of America's unbounded prosperity. Even more than most of the liberal state's programs in the past, the federal government's regional development efforts placed almost exclusive control into the hands of state and local elites. Frustrated by the circumstances of the Vietnam War, conservative reticence, and ensuing budget problems at the national level that left them feeling that their development program had been shortchanged, these local officials held a virtual monopoly on framing public debates and explaining the program's limitations and failures in rural areas - and, conversely, to take all the credit for governmentassisted economic expansion that did occur in the region's growth centers. In effect, ordinary Ozarkers could only learn about the program's inner-workings by reading the county newspapers and listening to the claims of local and state political leaders who administered it. In this elitecontrolled discourse, then, the inherent unevenness produced by regional and local boosters' plans for economic growth centers and "trickle-out prosperity" remained hidden beneath the lion's share of blame which focused on a stubborn and inept government in Washington.

The ORC's own limitations notwithstanding, parts of the Ozarks - particularly its more prosperous "growth centers" - continued to receive exceptionally large doses of locally- 
administered federal subsidies and rose to bask in America's thriving Sun Belt. ${ }^{82}$ Thus, in the mainstream political discourse of the New Ozarks, local and regional elites argued that if the federal government would simply allow it, other towns and communities could also "pull themselves up" like Fayetteville, Bentonville, Harrison, Mountain Home, and other bustling locales. This meant that, as one regional industrial development proponent put it, "in all fairness, it is time the Ozarks received its 'fair share' — nothing more, but hopefully nothing less"—of federal funding, but also, at the same time, that government bureaucrats in Washington should stay out of the way and leave local and regional political leaders, businessmen, and boosters absolute control in administering the designs of economic growth.

Ultimately, local elites had helped construct a New Ozarks industrial order built upon a combination of cheap and docile wage-labor, strong doses of government assistance, and the balance sheets of local, regional, and outside business owners which were shaped by the whims of a national and evermore global corporate climate. Economic growth and development brought newfound prosperity to some people and places in the region, but it worked to magnify the vulnerability and poverty of many others, particularly in small rural areas. The Ozarks-its new leaps of "progress" and "modernity" in certain towns and subregions notwithstandingcontinued to stand as one of the most impoverished areas of the country. But federal effort to eradicate poverty from the bottom up would not only fail to win the hearts of most rural Ozarkers but would help set in motion the beginnings of a new style of "damn guv'ment" defiance in the region. $^{83}$

\footnotetext{
${ }^{82}$ Moreton, To Serve God and Wal-Mart, 30-48; Blevins, Hill Folks, 213-218.

${ }^{83}$ E.L. Stewart Jr. to Robert E. Ruddy, October 12, 1972, Records of the Department of Commerce (RG 40), Ozarks Regional Commission, Federal Cochairman Organization Meetings and Policy, 1966-73, box 4, National Archives, College Park, MD.
} 


\section{Chapter Eight}

\section{Toward a New Defiance}

If the federal government's regional development scheme disappointed most rural Ozarkers because it did not do enough, its separate War on Poverty, which aimed more toward tackling poverty from the bottom up, tended to provoke bitter resentment and resistance in the region. New expressions of “damn guv'ment” defiance appeared, stoked, at least initially, by a pro-business, elite-constructed vocabulary. The liberal state's regional development program and its national War on Poverty, as one historian has written, "approached the problems of the region in different ways." While the former functioned as a literal "partnership between local, state, and federal governments to channel designated federal resources...[for] strategic development," the latter aimed to spur "community action" at the grassroots and "encouraged low-income participation." Inspired primarily by Johnson administration officials' concerns about the need to help poor blacks living under a southern political structure controlled by segregationists, federal War on Poverty programs were originally designed to circumvent state and local political establishments to take assistance directly to the poor themselves, a policy that very quickly raised the ire of local elites. ${ }^{1}$

By the late 1960s, however, local elites managed to co-opt many of the federal government's poverty programs, like they had most of the liberal state's initiatives throughout the past century, and persistently assaulted those that escaped their control. Ubiquitous attacks on and public smearing of the government's anti-poverty programs by agitated local and regional elites during the 1960s and 1970s helped set the course for new public debates about the role of

\footnotetext{
${ }^{1}$ Eller, “Modernization," 209-210.
} 
government in the Ozarks. At the same time, federal poverty warriors' and reformers' inability to tap into the traditional populist ethic among dispossessed rural folks failed to counterbalance the claims of the local power structure like backcountry agrarianism once had during the early twentieth century. This failure ensured that the government's War on Poverty came under fire in the rural Ozarks, even by many of those hill folks it intended to help. Indeed, it more broadly signaled the deflation of traditional anti-corporate populism in the rural Ozarks and the rise of a new anti-government ethic in its place.

Some Ozarks political leaders watched closely as the Johnson administration and the U.S. Congress worked on legislation after the president declared an "unconditional war on poverty" in his first state of the union address in January 1964. With the Appalachian Mountains standing as the national symbol of rural poverty and the central battle ground of federal efforts in rural America, a number of regional and local political leaders in the Ozarks hoped the government's War on Poverty would afford new opportunities to bring valuable federal funds to promote economic "modernization" in their region. In April, the Arkansas Democrat reported that Governor Orval Faubus had “put his enthusiastic stamp of approval on President Johnson's war on poverty program." While the governor believed that "the Ozarks are not as bad off as Appalachia"—or, he clarified, at least "as they write about" that region—Faubus initially believed that the mountain region of Arkansas should be an important priority as well. "All through the mountains here," Faubus explained, "there [is] what is termed underemployment...[and] people whose family income is below what is termed poverty level." "Prosperity is at an all time high," the governor said, echoing President Johnson, "but there are still pockets of poverty and many individuals even in the most prosperous areas who are not sharing in the wealth.” Though Faubus admitted that his gubernatorial administration would still 
need to give the matter some more thought, he stated that "we especially are going to emphasize projects of employment for youth," such as "improvements of the parks and beautification of our cities and highways." When asked to respond to conservative critics who warned of the "danger of the president's program" in returning to the frivolous and wasteful government spending of the New Deal era, Faubus "reminded the reporters that there are monuments existing today and will last our lifetime that came from President Roosevelt's anti-depression program."

Some county and local officials also jumped at what they thought would be a great opportunity to bring the government's War on Poverty money into their locales, mainly hoping to use it to stimulate economic growth. In June 1965, local officials in Pope, Yell, and neighboring counties in western Arkansas with mountainous areas straddling the Arkansas River formed the Arkansas River Valley Area Council (ARVAC), aiming to organize a multi-county program that could capitalize on federal anti-poverty grants in which localities were only required to put up ten percent in matching funds. Chickalah native Bob Adkisson, who was appointed executive director of ARVAC, remembered that initially the "group leadership...thought they were getting an economic development grant." "We realized, if Appalachia could get federal money, why couldn't we?" said Adkisson. Local officials soon discovered, however, that the grant "was really anti-poverty money," and not economic development funding. When President Johnson's anti-poverty chief, Sargent Shriver, arrived in Little Rock to "finalize" ARVAC's first six-month grant, Adkisson recalled that the federal official "was met by a contingent of bankers and power people" from the region, prompting Shriver to ask them "where the poor folks were." "Our leadership was thinking economic

\footnotetext{
${ }^{2}$ George Douthit, “Gov. Faubus Joins LBJ’s 'Poverty War,”' Arkansas Democrat, April 8, 1964.
} 
opportunity," Adkisson explained, and “didn’t realize focus was going to be soley [sic] on poverty."3

Congress passed the centerpiece of the government's War on Poverty in the form of the Economic Opportunity Act (EOA) in August 1964, which established the Office of Economic Opportunity (OEO). Title II of the EOA announced that its programs, unlike the federal economic development efforts, would be administered not by state or local governments but by newly-created Community Action Program (CAP) agencies that required "maximum feasible participation of the poor." After state, regional, and local leaders eventually grasped the seemingly ambiguous meaning of this clause in the federal law-the CAP concept "was initially misunderstood" even by President Johnson - it became clear that their ability to control the poverty programs would be limited. About a month after Governor Faubus's ringing endorsement of Johnson's War on Poverty initiatives, he changed his tune and told Arkansas's four U.S. Congressmen that "I don't want to see any federal program set up where the states are bypassed," urging them instead to support a much more decentralized anti-poverty measure that adhered to the American traditions of states' rights and local control. ${ }^{4}$

The requirements for community action and "maximum feasible participation" perturbed most local officials who felt entitled to manage federal anti-poverty programs in their areas as they saw fit. One of the most controversial programs created by the EOA was Volunteers in Service to America (VISTA), which, modeled on President Kennedy's Peace Corps, deployed

\footnotetext{
${ }^{3}$ Marvin Schwartz, "Bob Adkisson," interview notes, Arkansas VISTA Collection, series 1, box 1, folder 5, University of Central Arkansas Archives, Conway; Marvin Schwartz, In Service to America: A History of VISTA in Arkansas, 1965-1985 (Fayetteville: University of Arkansas Press, 1988), 61-64.

${ }^{4}$ Eller, "Modernization," 207, 209-210; Guian A. McKee, “"This Government Is with Us': Lyndon Johnson and the Grassroots War on Poverty," in The War on Poverty: A New Grassroots History, 1964-1980, edited by Annelise Orleck and Lisa Gayle Hazirjian (Athens: University of Georgia, 2011), quotation on 33; Orval Faubus to Wilbur Mills, May 8, 1964, Faubus Papers, box 482, folder 5.
} 
federally trained "volunteers" to needy areas with a mission to help energize poor people to improve their lives and communities. "For those already in power, those who resisted change," writes one historian, "VISTA was nothing short of subsidized anarchy.",

Storms of protest against the federal government's War on Poverty arose almost immediately as well from Arkansas business interests and Big Agriculture. Mrs. Arthur Alexander of the Little Rock area wired Governor Faubus a telegram in May 1964 to warn him that "you are losing hundreds of votes from the farmer, the planter, [and] the big and little business man" by endorsing President Johnson's anti-poverty agenda. "There are more of us than there are of the no work, all play, group," she said. Instead of participating in a wasteful government program, Alexander advised the governor to "have jobless men register with the employment agency." After all, she and her husband were "looking for tractor and transport drivers and men for other jobs." The Arkansas Farm Bureau's hostile opinion of the federal government's War on Poverty, moreover, quickly prompted that powerful agribusiness lobbying organization to issue petitions of protest "requesting its removal from the state."

A few days after Alexander mailed her letter, William P. Rock, the owner of a private industrial consulting firm based in Little Rock, wrote Governor Faubus to protest the federal government's War on Poverty. "Basically," he wrote, "poverty elimination is impossible in view of the way the departments of the Federal government restrict industrialization. They are strictly power-grabbing groups and cannot do anything of the nature that the President seems to think he can convince the people that he can do." "The truth of the matter is that industry's viewpoint is being completely ignored," Rock continued, which he believed was absurd because "industry is

\footnotetext{
${ }^{5}$ Schwartz, In Service to America, 3.

${ }^{6}$ Mrs. Arthur Alexander to Governor Faubus, May 11, 1964, Faubus Papers, box 482, folder 5; Schwartz, In Service to America, 100.
} 
the only force which can go into an area and truly relieve the poverty condition." "We are constantly aware ...from all of our 30,000 industrial contacts" that "labor costs" were the real impediment to growing the economy and, thus, solving the poverty problem, "such as [in] West Virginia where the mining unions under Mr. Lewis priced coal out of the fuel market," he explained. All the meddling government was doing with these programs, "thru such concentration of power at Washington," was "verifying...that the union bosses will move in behind the expansion and force those wages up." "This is what is holding up the full movement of industry today" and causing the persistence of poverty, Rock concluded. ${ }^{7}$

Similarly, the executive vice president of the Arkansas Chamber of Commerce asked fellow members in the May 1964 edition of the chamber's Arkansas Newsletter whether "this great big, prosperous, booming America of ours really need[s] to embark on an enormously costly and paternalistic spending spree to 'wipe out' poverty among the less affluent of our society?" "All over the world for the last two decades," he regretted, "the initials U.S. have stood for Uncle Sugar, that incredibly rich Croesus with an inexhaustible bag of golden gifts for all 'under-privileged' and 'emergent' peoples wherever situated." "As a matter of fact," he claimed, "many Americans didn't know the situation had changed greatly until all the antipoverty promotion got underway." Only then did they "beg[i]n to learn that vast areas of dire need and human want existed throughout the Nation and that the critical urgency of this lamentable development necessitated the immediate appropriation and expenditure of billions of dollars by the Federal government." Despite all of the talk about severe poverty in such states as Arkansas and West Virginia, the chamber of commerce spokesman wondered:

\footnotetext{
${ }^{7}$ William P. Rock to Orval Faubus, May 26, 1964, Faubus Papers, box 482, folder 5.
} 
Well, really how poor are we?...So far as Arkansas is concerned, the fact remains that there were more than 420,000 Arkansans holding non-farm payroll jobs in March at an average of $\$ 75$ a week or $\$ 3,800$ a year; fewer than 35,000 (including fringers and loafers) were out of work; 62,500 were employed in Arkansas's great agricultural industry which had a cash production in excess of $\$ 862$ million last year; and more than 115,000 self-employed and others were busy making a living. And as for the Johnson administration's claims about the needs for new government job training programs, he reminded his readers that the "American public school system is open to all." "Anyone who wants to go in business for himself finds the way open," and "those who want to work, who want to make a life for themselves and their families, are doing it." "The question is," he rhetorically asked: "Will the lavishing of taxpayers' dollars on all sorts of visionary schemes...be likely to inculcate in such persons habits of industry and thrift and thus eliminate improvidence from the American Scene?"

Widely-read national publications of the War on Poverty's conservative opponents also helped color the thinking of at least some rural residents in the Ozarks. In November 1964, A.F. Burgess of rural Pope County mailed Governor Faubus three articles he had torn out of his copies of the Reader's Digest that warned of the bloated government bureaucracy's dangerous urban renewal, infrastructure development, and anti-poverty projects. One of the articles, a reprint from the Wall Street Journal, objected to the government's "underlying theme" about poverty, which held that "society is the real villain, that all of us are jointly responsible for the plight of the poor," and declared that this line of thinking "is bad history and worse sociology." "Almost none of our forebears," the article stated, "considered it anybody's responsibility but his

\footnotetext{
8 “Memo to Members: That 'War on Poverty!"” Arkansas Newsletter 20 (May 1964): 3.
} 
own to see that he got up." "It was a lot of individual hard work and a great deal of freedom to move and act and think," it continued. "Henry Ford," after all, “...did more to bring abundance to the majority than any amount of doles or vote-getting programs," which proved "that a free economy and society expands the opportunities for all its members but leaves it largely to the individual to decide what he will do about them.” Burgess, whose bitter past experiences with New Deal farm programs during the 1930s and 1940s and rural economic development efforts since then had apparently destroyed any faith he might have had in government reform efforts, agreed with these conservative criticisms of the federal poverty programs. "We are not paupers and resent being treated as such, but with the war on poverty we cannot help ourselves," he told Faubus. "The only thing we [rural people] can do is to do as we did when crop control was put on us [which] is just get up and leave this area and start all over again." Burgess challenged the governor "to see if you can see any gain to the ones affected, not even the towns, and most people in them are against it."

Despite local leaders' misgivings about the intentions of federal anti-poverty programs in western Arkansas and the fact that "poverty was sort of incidental in the minds of those people," they went forward with the newly-formed ARVAC, which qualified as a CAP agency and "became very poverty conscious." According to director Bob Adkisson, the agency's compliance with the "maximum feasible participation" mandate "created a power struggle" with area elites. Nevertheless, the county judges and other local officials reluctantly "agreed" to adhere to the federal government's terms, he recalled, "but [they were] always trying to 'back door' [to] get the money for their use." The organization's use of federal Volunteers proved

\footnotetext{
${ }^{9}$ A.F. Burgess to Orval Faubus, November 28, 1964; and attached copies of Reader's Digest articles, "A Sure Cure for Poverty"; John Dowdy, "The Mounting Scandal of Urban Renewal"; and Sidney Z. Searles, "Bulldozers at Your Door," Faubus Papers, box 482, folder 6.
} 
especially divisive, so Adkisson explained that he and ARVAC "had to convince [the] power structure to let Volunteers come into communities and not put a muzzle on them. We had to tightrope that thing." Luckily for local officials, most of ARVAC's earliest Volunteers were older and "well accepted" reformers who worked on non-threatening projects like tutoring at local schools and organizing community art shows. At least one Volunteer, a retired Kansas school teacher in her seventies, even joined the local chamber of commerce and believed that America's biggest problem was that "we are losing our heritage of a strong moral people, becoming a nation of curs." Eventually, like many other CAPs, ARVAC began to get some younger, "anti-establishment" Volunteers who were "having a field day with their idealism," and Adkisson recalled that "there was some struggle between them and the county judges." Nevertheless, ARVAC and its poverty warriors "never got as radical here as elsewhere" and managed to mostly "appease local power entities." Still, regional and local officials remained on their guard, especially as troubling news about poverty programs arrived from other parts of the state and nation. ${ }^{10}$

Contrary to Faubus's initial assumption that the rural Ozarks would be the focus of the government's anti-poverty initiatives in Arkansas, many federal officials and national reformers determined to connect the War on Poverty with African Americans' struggles and activism for civil rights. "The War on Poverty has usually been seen as distinct from the southern civil rights movement," writes historian Annalise Orleck, "but the two historic movements were inextricably tied together." ${ }^{\prime 11}$ The black communities in the lowlands of the eastern part of the state, then,

\footnotetext{
${ }^{10}$ Ibid., 64-67, 72; Schwartz, "Bob Adkisson," interview notes.

${ }^{11}$ Annelise Orleck, "Introduction: The War on Poverty from the Grass Roots Up," in The War on Poverty: A New Grassroots History, 1964-1980, edited by Annelise Orleck and Lisa Gayle Hazirjian (Athens: University of Georgia, 2011), 15.
} 
became a focal point in Arkansas, and it did not take long for controversy to brew among resentful whites.

Even in the Ozarks, where whites made up well over ninety percent of the population, the image that the national War on Poverty was ostensibly a "special interest" program for blacks and social radicals alarmed a number of rural whites. In September 1964, for instance, Mrs. Cyrus Stutchman, the wife of an elderly retired coal miner and small farmer in Franklin County, sent a letter of protest to the governor about federal poverty officials' plans to establish a youth training center in her county. "I think it would be a bunch of red trained youths of course," she wrote, and "there will be niggers in the crowd." "I think we should keep such out of our state," Stutchman continued. "Our Government is so set on tearing up our way of life so do not let the Government put another one over on us." Governor Faubus responded to assure her that "I will consider carefully the establishment of any camp in Arkansas...before giving my approval." Then, thanking Stutchman for her letter, Faubus pleaded with her with his typical populist appeal, telling her that "I need all of the help I can get to defeat the millionaire candidate [Republican Winthrop Rockefeller]" and urging her and her neighbors to make sure to pay their poll taxes before the deadline. ${ }^{12}$

Faubus won the 1964 election but opted not to run for re-election in 1966, ending his unprecedented twelve-year tenure in office. His last opponent, progressive Republican Winthrop Rockefeller, who had served as a chief economic advisor in the Faubus administration, won the governor's office in the 1966 election. The new governor, whose nephew Jay Rockefeller-the

\footnotetext{
${ }^{12}$ Mrs. Cyrus Stutchman to “Gov. Laney," n.d. and Orval Faubus to Mrs. Cyrus Stutchman, September 3, 1964, Faubus Papers, box 482, folder 6. Stutchman apparently thought she was writing her letter to Ben Laney, the ardent states' rights Arkansas governor who had served from 1945-1949 and had joined the southern Dixiecrat revolt, perhaps indicating her strong views on race.
} 
future West Virginia governor and U.S. Senator-had worked in the VISTA program in Appalachia in 1964, endorsed the federal government's War on Poverty when he took office in 1967. In November of that year, OEO head Sargent Shriver wired Rockefeller a telegram to give him his "most sincere thanks for your public endorsement of the War Against Poverty in the Washington Evening Star last night." In fact, Arkansas's black voters had cast the deciding votes for Rockefeller's election, so the new Republican governor prioritized utilizing federal poverty programs to assist his African American constituents in the eastern part of the state. ${ }^{13}$

Nevertheless, like Faubus before him, Rockefeller resented the federal government's efforts to bypass state and local power structures. In October 1967, Rockefeller wrote Rochelle Stanfield of the National Governor's Conference's Office of Federal-State Relations to complain that "it alarms me that even though most of the Governors have stated the need for an increase in state involvement, OEO insists on giving the states such a minor role."14 Congress ultimately responded to state and local political leaders' protests by passing the Quie and Green Amendments to the EOA that year, which gave "local officials the power to designate which community organizations were eligible for federal money" and stipulated that "elected officials would now comprise a third of the local poverty boards and could fill another third of the seats with welfare professionals and representatives of the private sector."15 These changes in federal law, according to historian Ronald Eller, "effectively eliminate[ed] maximum feasible participation of the poor."16 After Congress granted states more authority over federal poverty

\footnotetext{
${ }^{13}$ Dillard, "Winthrop Rockefeller (1912-1973)"; Sargent Shriver to Winthrop Rockefeller, November 8, 1967, Winthrop Rockefeller Papers, box 322, file 56, University of Arkansas at Little Rock Special Collections, Butler Center for Arkansas Studies, Little Rock (hereafter cited as Rockefeller Papers).

${ }^{14}$ Winthrop Rockefeller to Rochelle Stanfield, October 11, 1967, Rockefeller Papers, box 322, file 56.

${ }^{15}$ Orleck, "Introduction," 17.

${ }^{16}$ Eller, "Modernization," 213.
} 
programs, Rockefeller even used his veto power to block an OEO project, a supplemental food stamp loan, in black-majority Phillips County. ${ }^{17}$

Publicity about controversial anti-poverty projects and community action in the black communities of eastern Arkansas spread to help color many white people's perception of the federal government's War on Poverty throughout the whole state. White animosity raged in the Delta. In June 1969, an angry mob beat two VISTA volunteers "with coffee cups and other items" at a café in Hughes, an assault that severed one of the victim's arteries. In November 1969, planter T.H. Barker penned an angry letter to the Arkansas Gazette that claimed that "Lee County did not acquire this poverty status until a group of bureaucrats decided we should wear this label...I hope the Volunteers have been frustrated by the farming empire...for we have been frustrated by many bureaucratic mandates ...that you and your kind have administered on an unsuspecting community." Milton Davis, another Lee County resident, contended that "this is nothing short of socialized anarchy" and insisted that "it is about time we all stopped and took a good look around and demanded that our government put these funds to better use." Not surprisingly, the (White) Citizen's Council in Lee County also issued a statement condemning the "NAACP (National Association for the Agitation of Colored People), OEO, VISTA (Vipers in Subversion to America), and other trouble making organizations." "These same Communist organizations," the council claimed, "are the cause of the population ratio in Marianna to change" to a black majority in recent years. "Are you going to join with others NOW or AFTER

\footnotetext{
${ }^{17}$ Winthrop Rockefeller to Walter Richter, September 29, 1967, Rockefeller Papers, box 322, file 56. Rockefeller explained that he had made his decision because the state welfare department "has been dissatisfied with the manner in which the program has been conducted" and because 98 percent of the money was going to families with incomes of at least $\$ 30$ per month.
} 
they burn your business or home or assault your wife or daughter?” asked the Citizens' Council. $^{18}$

Even in the Ozarks, which by the mid-twentieth century was comparatively one of the whitest regions in the country, black activism stirred some controversy over federal poverty programs. One of the region's few black communities resided in East Fayetteville near the University of Arkansas. When the federal government's War on Poverty began, Bobby Morgan, a native son of the black neighborhood, became interested in helping to start a community action agency for his home county and wrote the new Washington County Community Action Agency's first successful grant application for job training assistance in 1965. As the agency organized and as federal money started to come in, however, Morgan remembered that "local politics got involved," and, despite the federal mandate for "maximum feasible participation" before 1967, he claimed that "only the power people had the power-judges, mayor, sheriff." Morgan drafted one of the agency's largest funding proposals for a "mobile social clinic" to help serve all of Washington County, but especially the black community, with supplemental services such as medical care, library resources, and welfare information. The $\$ 480,000$ grant awarded by the federal government for the project, however, "was used for other things" by local political leaders, according to Morgan. Furthermore, Morgan claimed that after he started a new program to provide meals for hungry children in Fayetteville, entrenched elites sent in county health officials to shut it down, citing the "unsafe" and "unsanitary" conditions of the house where it operated out of. ${ }^{19}$

\footnotetext{
${ }^{18}$ Schwartz, In Service to America, 197-199; Arkansas Gazette, November 29, 1969 and February 5, 1970.

${ }^{19}$ Schwartz, In Service to America, 161-165; Marvin Schwartz, "Bobby Morgan," interview notes, Arkansas VISTA Collection, series 1 , box 1 , folder 1 .
} 
One of Morgan's fellow white Volunteers also remembered that Steve Cummings, the son of the local circuit court judge who had been installed as the agency's director, "really had conflicts" with the federal aides and "the low income neighborhood people." When "EOA staff people and neighborhood people were having meetings at night," Cummings "would break in and accuse them of having secret meetings," he claimed. By 1968, financial irregularities and suspicions of corruption finally prompted the Rockefeller administration and the southwest regional and national offices of the OEO to investigate the Washington County agency. An official at the southwest regional office noted in a memo in November 1968 that the "Agency is shot through with corruption. [But the] Regional CAP is helpless to change this because of politics and the inability to prove anything illegal." To make matters worse, the official guessed that the "Vols will probably be asked to leave because of what they have exposed" and because they "were somewhat instrumental in bringing [the] investigation of the agency." Despite a dead end in the investigation, however, Director Cummings resigned the following year. ${ }^{20}$

Frustrated by his experience with the Washington County agency, Morgan left to take a position with the OEO's Rural Training Center in Little Rock, but he remained committed to bringing change to his hometown and surrounding areas in northwestern Arkansas. Having come to believe that "you'd either be with the power structure or against them [but] couldn't be neutral," Morgan resolved to challenge elites' control over local affairs. Through the Rural Training Center, he helped spearhead a voter registration and education campaign and exposed rampant election fraud throughout the state. In rural Madison County, the home of the former governor, Morgan claimed that he and his associates "knocked the top off the Faubus thing of

\footnotetext{
${ }^{20}$ Marvin Schwartz, “Charles Johnson,” interview notes, Arkansas VISTA Collection, series 1, box 1, folder 6; "WASHCO-EOA - Steve Cummings," November 1968, transcription of memo by Marvin Schwartz, Arkansas VISTA Collection, series 1, box 1, folder 6 .
} 
votes from dead people" after they spent "two weeks to get names off tombstones [and] put them against county voter records." "We started to penetrate with info about elected officials," he explained, "and [the power] folks raised hell." "Every so often state troopers would come in and round us up. Ask us to identify our people [and] Hassle us about things," Morgan recalled. ${ }^{21}$ Meanwhile, intense conflict also flared up in Washington County, particularly between the small black community in Fayetteville and the local white political establishment. In the summer of 1969, black youths in Fayetteville "riot[ed] in the streets" one night and a "police car [was] set on fire." "After that," remembered a VISTA volunteer working in Washington County, "many of our efforts [were] stymied" to the point that anti-poverty reformers "couldn't speak with [the] county judge or mayor." Several years later when the feather-ruffling Morgan finally returned home to East Fayetteville in 1981, he claimed that grudge-bearing local elites had him arrested on trumped up charges of "weed" possession and had him locked away in the county jail for four months. ${ }^{22}$

Black activism and its role in the government's War on Poverty in Washington County, particularly in the city of Fayetteville, however, was an exception in the Arkansas Ozarks. In a region with a white population well in excess of ninety percent and where most counties had no black residents at all, the civil rights struggle rarely figured directly into the affairs of antipoverty programs in rural Ozarks communities. Nevertheless, the public image associated with the War on Poverty and its links to African Americans' and other "radicals"” fights for civil rights left a strong impression in the region about the programs' intentions and provided local elites who opposed the government programs with powerful ammunition to help discredit anti-

\footnotetext{
${ }^{21}$ Schwartz, In Service to America, 166-167; Schwartz, "Bobby Morgan," interview notes.

${ }^{22}$ Marvin Schwartz, "Paul Williams," interview notes, Arkansas VISTA Collection, series 1, box 1, folder 6; Schwartz, "Bobby Morgan," interview notes.
} 
poverty reform efforts among rural residents. Earl Evans, the African American director of the OEO's Rural Training Center in Little Rock, described this matter of image among Arkansas whites who saw the federal government's War on Poverty as mostly a "special interest" program for blacks. Evans regretfully believed that "ninety-eight percent of the people don't understand the poverty program, mistakenly thinking it was only for blacks."23

That race was an issue that tended to pervade rural white Ozarkers' views of the government's War on Poverty was undeniable. More broadly, this issue of race paralleled other developments of the populist ethic in the region during the postwar era, such as the rise of antiunionism in labor relations. As historian Michael Pierce argues, many working-class whites in the rural Ozarks "came to believe that the labor movement was too closely associated with the civil rights movement, outside agitators, and an eastern elite," which helped "erode the region's [traditional] pro-labor culture." Racial barriers, after all, had long stood firm in the region's populist ethic. ${ }^{24}$

Elsewhere in America (including parts of Appalachia), poverty warriors at times succeeded in uniting poor blacks and whites in a "struggle for social justice for all people" against economic inequality and local elites' "special interests." In the Ozarks, however, federal Volunteers working in rural communities tended to view the racism of rural whites as an inevitable and largely insurmountable obstacle engrained in the region's backward, isolated culture. ${ }^{25}$ White Boston native Bob Gorman, for instance, came to all-white Newton County-

\footnotetext{
${ }^{23}$ On black population, see Blevins, Hill Folks, 212; Evans paraphrased in Schwartz, In Service to America, 49.

${ }^{24}$ Michael Pierce, "Orval Faubus and the Rise of Anti-Labor Populism in Northwestern Arkansas," in The Right and Labor in America: Politics, Ideology, and Imagination, edited by Nelson Lichtenstein and Elizabeth Tandy Shermer (Philadelphia: University of Pennsylvania Press, 2012), 113.

${ }^{25}$ On poverty warriors' efforts to unite poor blacks and whites in Appalachia, see Thomas Kiffmeyer, "Looking Back to the City in the Hills: The Council of the Southern Mountains and a Longer View of the War on Poverty in
} 
the most mountainous and poorest county in Arkansas - to work in the VISTA program in the late 1960s. Before coming to the Ozarks, Gorman, who had originally been trained "to community organize in urban black communit[ies]," said that his supervisor in Austin, Texas, had him "reading everything about Newton Co." and the Ozarks he could find to become familiar with the supposedly peculiar culture of the area. After he arrived in the mountains, though fascinated by the mountain "bootleg" he had expected to find, Gorman was convinced that "we were on the leading edge of general decadence in [the] area" and was certain that the people "hadn't been exposed to outsiders." He recalled that one day "2 bus loads" of mostly black kids participating in a federal Upward Bound program in the Arkansas River town of Russellville came to Newton County for a day-long outing to explore the scenic Buffalo River and picturesque mountains in the area. Apparently amused at the rural folks' presumably isolated mountain culture, Gorman claimed that the "looks on those locals' faces was like the end of the world. They didn't have enough rope in town to hang all those kids." Gorman believed that the black children's visit to the mountains and safe return to Russellville signaled a "minor silent victory" for these hill folks who remained stuck in a nineteenth-century mountain culture. ${ }^{26}$

Gorman's assumptions about the "culturally backward" hill folks he intended to help reflected more broadly the key failure of federal poverty warriors' efforts to win the trust and support of poor rural Ozarkers, which meant that they posed a weak challenge to local elites' highly-publicized assaults on the federal government's "wasteful" and "dangerous" programs. Like many of the earliest outside reformers who went to work in Appalachia, most poverty warriors who descended on the Ozarks primarily aimed to tackle the rural region's supposedly

the Appalachian South, 1913-1970," in The War on Poverty: A New Grassroots History, 1964-1980, edited by Annelise Orleck and Lisa Gayle Hazirjian (Athens: University of Georgia Press, 2011), 378-381, quotation on 379. ${ }^{26}$ Marvin Schwartz, "Bob Gorman," interview notes, Arkansas VISTA Collection, series 1, box 1, folder 5. 
pathological "culture of poverty" and "alter the value system of the mountain people." For the most part, as historian Thomas Kiffmeyer explains, many urban and middle-class reformers believed that the Mountain South's problems could be largely boiled down to rural people "perpetuating their impoverishment by clinging to outdated customs, values, and traditions." This paternalistic assumption effectively "placed the burden of poverty on the poor and ignored its real sources," namely the destruction of the region's small farm economy and industrialization's grossly uneven consequences. It also tended to offend the proud hardscrabble people reformers' programs aimed to help. ${ }^{27}$ Unlike the farmers' organizations and populist and agrarian socialist movements that had mobilized poor and middling backcountry folks to challenge the status quo in the late nineteenth and early twentieth centuries, 1960s and 1970s poverty reformers remained unable to connect with the rural dispossessed in order to rekindle the traditional populist defiance against economic inequality and dominance by local and regional elites.

Poverty reformers' recollections of "culture shock" when they entered the region illuminate their prevalent attitudes and assumptions about the rural poor they came to help. VISTA trainer Neal Blakely recalled that he always "tried to tell them [federal poverty reformers] what kind of culture they would be working with" and that they should "understand how regional Arkansas is." When VISTA volunteer Anna Gottlieb of Illinois found out she had been assigned to Arkansas, she "seriously thought of leaving" the program. "To me," she explained, "Ark was the backwards of backwards" and "just a place you were born and stuck in."

\footnotetext{
${ }^{27}$ Kiffmeyer, "Looking Back to the City in the Hills," quotations on 370, 364, and 369 respectively. For an excellent treatment of the "culture of poverty" theory in twentieth-century intellectual and political discourse, see Alice O'Conner, Poverty Knowledge: Social Science, Social Policy, and the Poor in Twentieth-Century U.S. History (Princeton: Princeton University Press, 2001).
} 
Though she became good friends with her VISTA partner there, she "realized why they [program officials] didn't tell you where you were going to go until you were into training." Had she known she would be sent to rural Arkansas, she "wouldn't have gone." While rural New Yorker Carolyn Rose initially welcomed her assignment to rural Arkansas, she explained that after she arrived "I couldn't believe I had wanted to come to this state." "Unfortunately," she stated, "I never got used to Ark." Barbara Conard, while she insisted that she endured "emotional shock, not culture shock," remembered being taken aback by the isolation-induced rural fatalism and apathy she encountered, particularly when she met an impoverished woman dying of cancer and caring for "kids yelling and screaming" in a dilapidated house who seemed "so submissive and so polite and so thankful" despite her tragic and unacceptable situation. California native Jane Spencer, after completing her one-year tenure administering federal programs with the Community Resource Center in Newton County, became convinced that "family violence is accepted as a way of life among many of these mountain families." And John Boyle, who split time as a federal Volunteer between Houston, Texas, and northwestern Arkansas, remembered "what a culture shock" he experienced in going "from inner city Houston" to the rural Ozarks, where, even though he was assigned to Washington County in the most "progressive" and affluent part of the region, he found the people to be exceptionally parochial and clannish. ${ }^{28}$

Federal poverty warriors working in the Ozarks, in fact, typically held up this presumably peculiar and primitive rural mountain culture to explain why they could not get the poor hill folks who they intended to help on board with their programs. In particular, the age-old caricatures and popular images of culturally stagnant mountaineers' knee-jerk reactions to any

\footnotetext{
${ }^{28}$ Marvin Schwartz, "Neal Blakely," interview notes; "Anna Gottlieb," interview notes; "Carolyn Rose," interview notes; "Barbara Conard", interview notes; "Community Resource Center: Jane Spencer," interview notes; and "John Boyle," interview notes, Arkansas VISTA Collection, series 1, box 1, folder 6 .
} 
and all change and their "rugged pioneer lifestyles" — complete, that is, with the same "such attitudes that allowed the early Arkansas settlers to survive in a sparsely populated wilderness"loomed large in how outside reformers interpreted the rural resistance they encountered. One observer of anti-poverty efforts in the region stated, after all, that the federal reformers "arrived in Arkansas more or less only one hundred years after the pioneer period.” By the 1960s and 1970s, he guessed that "a typical family patriarch might be the son or grandson of the original pioneer who built his cabin from trees he felled and shaped, who fed his family from the game he hunted and trapped," so it stood to reason that stubborn frontier attitudes remained dominant in the isolated Ozarks. ${ }^{29}$

Reformers might have fared better had they come to understand the historical dynamics of rural defiance in the region — particularly the traditional populist ethic — and, popular stereotypes to the contrary, the enormous economic and social changes that had transpired since the nineteenth century. In parts of Appalachia and urban black and other non-white ethnic communities, after all, many national poverty warriors eventually "began to question the validity of the cultural explanation" about the poor they were assisting and began to succeed in helping mobilize grassroots community action. In Appalachia, for instance, a number of reformers began to hone in on the industrial dominance of King Coal and its role in that region's economic and political inequality as the primary source of poverty. "Reformers began to argue that the region should be seen as a colony of corporate energy interests," writes one Appalachian historian. Hence, despite their flaws, a number of reformers eventually helped ignite new waves of populist resistance and to give rise to a new collective sense of "Appalachian nationalism" among

${ }^{29}$ Schwartz, In Service to America, 464-465. 
dispossessed natives in some places. ${ }^{30}$ Likewise, the civil rights struggle provided "black communities... a national identity movement to support and encourage their efforts," according to another historian. Meanwhile, however, "the hill culture of the Ozark and Ouachita Mountains...had no such external support."31 Rural mountain folks remained "caught between two external forces, a reform movement...that thought it knew better and those industrial interests...that...dominated the region," as historian Thomas Kiffmeyer puts it. ${ }^{32}$

Unlike in Appalachia where the omnipresent coal corporations delineated clear lines between the haves and have-nots and in many black communities where racial discrimination literally made poverty a "black and white" issue, identifying the real sources of problems and organizing effective solutions remained far more elusive to reformers in the rural Ozarks. The extinction of smallholder farming and its replacement by an uneven low-wage, non-union industrial and agribusiness economy were central to the region's problems. Federal poverty warriors working in the Ozarks, however, who generally believed in the inherent superiority of urban middle-class values — even those schooled in radical organizer Saul Alinsky’s Reveille for Radicals (1946), which called for the creation of "people's organizations" to "precipitate the social crisis by action... by using power"- - failed to wrap their minds around such an analysis, clinging instead to popular rural and hillbilly stereotypes. ${ }^{33}$ Even after spending more than a year working in rugged and impoverished Newton County, federal Volunteer Bob Gorman, for instance, admitted that "I never really knew what I was there for.",34

\footnotetext{
${ }^{30}$ Kiffmeyer, "Looking Back to the City in the Hills," 373, 381.

${ }^{31}$ Schwartz, In Service to America, 464.

${ }^{32}$ Thomas Kiffmeyer, Reformers to Radicals: The Appalachian Volunteers and the War on Poverty (Lexington: University Press of Kentucky, 2008), 14.

${ }^{33}$ Orleck, "Introduction," 12.

${ }^{34}$ Schwartz, "Bob Gorman," interview notes.
} 
Federal reformers in the Ozarks, as we have seen, experienced firsthand and, thus, quickly came to recognize the unequal power structure and its lopsided dominance by local elites who controlled the region's economic and political order. But they also tended to mistrust the poor and common folks they were there to help, despite their sympathy for them. Convinced that these rural folks carried too much backward cultural baggage, poverty warriors held little confidence in poor Ozarkers' own abilities to actively seek change. VISTA volunteer Donna Clark, for instance, who spent time in both the Ozarks and the Delta regions of Arkansas, simply believed that "change was more difficult here [in the hill country] than in east Arkansas." She thought her work in the Ozarks was "time well spent" because "we did a few nice things for people, taught a few to read," but her experience in trying to help reform conditions of poverty amid an exceptional rural hill culture "left with me less faith in the ability to change." Social worker Fred Morrow likewise believed that Ozarkers' "resistance to change [was] related to [the] cultural level of the state." "Hill people," he claimed, "had keen awareness of having problem[s], but [the] idea of letting someone come in and help was alien to their values." Even in those cases when federal poverty warriors succeeded in getting rural people on board with programs, another reformer regretted that stubborn hill folks always insisted that "it's all on their terms. ${ }^{35}$

With the "backward culture" paradigm dominating most of their thinking, poverty reformers failed to tap the strong tradition of economic populism in the rural Ozarks. Instead, they tended to promote the expansion of industrial employment opportunities and the habits and values of America's capitalist culture as the best prescriptions for the rural Ozarks. Testifying

\footnotetext{
${ }^{35}$ Schwartz, "Donna Clark," interview notes; "Fred Morrow," interview notes; and "John Boyle," interview notes, Arkansas VISTA Collection, series 1, box 1, folder 6.
} 
before the Congressional Subcommittee on Rural Development in June 1967, Glen Jermstad, the director of the Arkansas Office of Economic Opportunity, explained that while "the United States is a prosperous nation with pockets of poverty...Arkansas is a poverty-stricken state with pockets of prosperity," and "the counties of northern Arkansas, in the Ozark mountains, represent poverty at its worst." The main reason for this, Jermstad argued, failing to acknowledge the enormous agricultural transformations that had depleted the smallholder farm economy, was that "Arkansas is still an agricultural and rural state, and in those areas lies the problem." Rural cultural isolation, Jermstad noted, in addition to the scant availability of "modern" industrial jobs, lay at the heart of the problem. "The problem of poverty," he insisted, "is a problem of education - how to provide it, how to improve it, how to convince the poor of the advantages of getting it." "Poor soil, poor transportation, poor education, all produce poor people." ${ }^{36}$

To be sure, the extinction of more independent smallholder farming by the 1960s and 1970s had vastly eroded the backcountry society that had given rise to agrarian defiance in the late nineteenth and early twentieth centuries. Yet the vestiges of traditional populism remained evident even among a number of middling Ozarkers who strove to adapt their rural lives to the industrial and agribusiness economy of the New Ozarks. Beginning in 1962, for instance, significant numbers of rural poultry farmers in the region began to organize growers' associations to challenge large industrial processing companies' vertical integration tactics and hegemonic control of markets. "Major firms such as Tyson and Arkansas Valley Industries preferred to accept the inefficiency of dealing with many individual growers rather than diminish

\footnotetext{
${ }^{36}$ Glen L. Jermstad, untitled position paper presented to the Subcommittee on Rural Development of the U.S. House of Representatives, June 26, 1967, Rockefeller Papers, box 322, file 56.
} 
their control over production costs," notes one Arkansas historian, so the "organization[s] died in the face of such hostility." Even so, "the idea of grower bargaining rights gained force" among many Ozarks poultry farmers who continued to struggle against the uneven consequences of corporate power and "coercion." ${ }^{, 37}$ Nevertheless, most progressive reformers continued to believe that the rural hill people's “independent, self-reliant nature, [and] suspicio[n] of government programs and so-called new ideas," as one federal program director put it, made it nigh impossible to rally them together to improve their lives. ${ }^{38}$

Federal poverty reformers also missed other opportunities to arouse the old tradition of populist activism in the rural Ozarks, namely in neglecting the region's dissenting religious culture. Like the small farm economy, the religious scene had also changed remarkably in the Ozarks by the 1960s and 1970s. "Another twentieth-century casualty of rural modernization has been the country church," writes Ozarks historian Brooks Blevins, since the rapidly dwindling numbers of rural residents who remained in the region "beg[a]n driving to nearby towns in order to join large congregations" during the post-World War II era. ${ }^{39}$ Thus, the small and independent backcountry churches, where many poor and middling Ozarkers had drawn inspiration for their populist defiance during the late nineteenth and early twentieth centuries, had largely disappeared. Nevertheless, a significant gap between the rural "disinherited" and the more affluent middle-class Christians in the region remained visible in the Ozarks during the second half of the twentieth century, and remnants for a potential revival of traditional populist religious dissent survived.

\footnotetext{
${ }^{37}$ Ben Johnson III, Arkansas in Modern America, 1930-1999 (Fayetteville: University of Arkansas Press, $192-193$.

${ }^{38}$ Schwartz, "Community Resource Center: Jane Spencer," interview notes.

${ }^{39}$ Blevins, Hill Folks, 202-203.
} 
Poverty activist John Pelkey observed the socioeconomic divisions entrenched in the religious community of the Pope County locale where he worked during the 1960s. As for the most prominent church there, an Assembly of God congregation, Pelkey noticed that "members are mostly not from low income families," and he even suggested that "some look down on the low income families as trash beneath their feet." Likewise, federal poverty reformer John Lewis noted in his journal the barriers that existed between the well-to-do and rural poor in the region's postwar Christian culture. Lewis even confronted the managing editor of the Arkansas Methodist about why there seemed to be such a well-defined line between the haves-the "good, Christian folks," as he sarcastically referred to them—and the have-nots in Arkansas's mainstream church environment. The editor, he said, responded to his inquiry by saying "Well, we've had to work hard for what we have," prompting a frustrated Lewis to simply scribble in his journal: "Come on, lady!" Yet, while federal poverty warriors often worked successfully with African American churches to promote community activism in American cities, they proved unable — or, perhaps more accurately, unwilling — to connect with rural religious sentiments in the Ozarks. In fact, the "religious fundamentalism" of rural Ozarkers, as one federal poverty worker in the region noted, typically figured high on reformers' list of the "cultural problems" that needed to be overcome and supplanted. ${ }^{40}$

Politically conservative Christian leaders in the region and nationally, meanwhile, worked diligently and far more successfully to forge a new popular climate of religious dissent, one increasingly directed not, as in the past, against greedy economic elites but now at an abusive and meddling government. The transformation of many Church of Christ congregations

\footnotetext{
${ }^{40}$ Schwartz, "John Pelkey," interview notes, Arkansas VISTA Collection, series 1, box 1, folder 6; John Lewis, $A$ Vista Diary (n.p., 1969-1970), 2-3 (available in Arkansas VISTA Collection, UCA Archives).
} 
during the post-World War II era is a case in point. The staunchly independent fundamentalist Christian tradition of Sam Faubus and many other early-twentieth-century dispossessed rural populists and agrarian socialists in the region underwent steady institutionalization and centralization during the postwar era. Though the Churches of Christ maintained their tradition of local congregational authority, Harding College (now Harding University), located just south of the Ozarks escarpment in White County, came to exert a heavy influence on many local churches' teachings and beliefs throughout the region. Under the long tenure of college president George Benson, who had first saved the small institution from closing its doors during the 1930s and then grew it into one of Arkansas's largest private colleges by forging important financial ties with wealthy corporate benefactors, particularly in the southwestern oil industry, Harding became a bastion of evangelical conservatism during the postwar period, not only in the Ozarks and surrounding regions but nationally. Benson's National Education Program at Harding informed both students and the general public about the "pernicious" government and its threats to free enterprise and America's rightful place as a Christian nation. Similarly, conservative radio evangelists such as Billy James Hargis warned fellow Christians of communist subversion and an elite-run, high-handed government that was forcing America to turn its back on God. ${ }^{41}$

By the late 1970s, the battles waged by local elites to exert absolute control over federal poverty programs combined with government reformers' failures to tap into the populist ethic in the rural Ozarks to leave conservative opponents of the liberal state's social betterment programs

\footnotetext{
${ }^{41}$ On the transformation of the Churches of Christ during the postwar era, see David Edwin Harrell Jr., The Churches of Christ in the Twentieth Century: Homer Hailey's Personal Journey of Faith (Tuscaloosa: University of Alabama Press, 2000), 115-175. On Harding College, George Benson, and Billy James Hargis, see, Darren Dochuk, From Bible Belt to Sun Belt: Plain-Folk Religion, Grassroots Politics, and the Rise of Evangelical Conservatism (New York: W.W. Norton, 2011), 60-66, 112-114, 128-134, 237, 256, 270-271; Bethany Moreton, To Serve God and Wal-Mart, 164-168, 171.
} 
a near free reign in public debates about the proper role of government. In 1980, Carroll County Judge Wayne Farwell and several area businessmen joined the editor of the Carroll County Tribune and the owners of the local television and radio stations to launch a vigorous "grass-top" campaign to dismantle the Ozark Institute (OI), a non-profit anti-poverty agency based in the tourist town of Eureka Springs. In accordance with the Comprehensive Employment and Training Act (CETA), which had been signed into law by President Nixon in 1973, the U.S. Labor Department had recently authorized an $\$ 822,799$ grant to the OI to help conduct regional job training, rural sustainability, and welfare awareness programs. Judge Farwell derided the OI programs as a "duplication of services" and insisted that "if we are going to spend money for this purpose, let's use our long established institutions to administer it and not create a new one which will cost many thousands of extra dollars for administration." "Being in public office for $3 \frac{1}{2}$ years has made me more aware of the many government giveaway programs and frankly it scares me to death," Farwell added. "I would like to see all, and I mean all, of these programs abolished, then build back the few we really need. I keep thinking that if we ever reach the point where we have more riders than we have pushers, we are in big trouble, and I think we have about reached that point." ${ }^{42}$

Prominent Berryville resident, self-described “Ozark Mountain farmer," and local folk culture author and enthusiast Lanny Gibson echoed Farwell, lamenting that "this growth called bureaucracy is a fire-breathing dragon like Grendel in Beowulf, or it may be a club-wielding Cyclops, or a snaky-haired Gorgon that turns all who look at it to stone, or a Hydra that doubles

\footnotetext{
${ }^{42}$ County Judge Wayne Farwell, "Letter to the Editor," Carroll County Tribune, September 12, 1980. Apparently, the OI originally requested $\$ 985,141$ for its 1981 programs, but the Labor Department authorized $\$ 822,799$.
} 
each time it's cut, or that creature with many eyes I can't think of right now." ${ }^{43}$ The owner of the local television station, Clyde Payne - an urban Illinois native who once explained in a local newspaper article that "I got fed up with the rat-race and high falutin' living up around Chicagoland, so I tossed everything into my covered wagon and struck out for the Ozarks"likewise warned rural and small-town Ozarkers about the OI's "hippie" director, Edd Jeffords, whose philosophy, he suggested, was that "after a few puffs on the peace pipe, everything will be rosy." Payne described a verbal confrontation he had with Jeffords, a native of eastern Arkansas, in which he claimed the hot-tempered OI director rabidly barked at him: "Once a Damyankee, always a Damyankee.” Payne insisted that, in fact, "in just a short time [in the Ozarks]...I had become converted to an Orthodox Confederate" and told his local readers that Jeffords, who he referred to as "Gen U.S. Grant," was actually the real "Damyankee Traitor."

Since that day, when I met old U.S. Grant, he has come pretty far. He's set up his Union Headquarters in a downtown building and staffed it with his Damyankee friends, and most of us Confederates don't even know it. And instead of him dealing in that $\$ 500$ and $\$ 1,000$ stuff, he's throwing it away by the millions! And still, he hasn't told ANYONE (nor has anyone asked) just where the money is coming from. His latest brain-child is to conscript 80 or 90 of his Damyankee friends, and in just 6 weeks teach them how to grow grass... at a cost of a million bucks.

'I'm a hard-working, taxpaying converted Confederate who can't seem to qualify for welfare and food stamps," Payne continued. "So I'm warning you again, my Confederate friends-if

\footnotetext{
${ }^{43}$ Lanny Gibson, "Letter to the Editor," ibid., September 12, 1980. Gibson authored a self-published folk-humor book, titled The Magic of Scrub Holler: Ozark Mountain Life, in 2001.
} 
you want a few coins left in your pockets for jingling, you'd better start doing some thinking and throw in with the judge and me." 44

Beginning in June 1980, Eureka Springs tourism booster Jane Girkin made use of the local radio station and area newspapers to start a petition drive to demand that Arkansas's firstterm governor, the young and "liberal" Bill Clinton, utilize his state veto power to kill the federal CETA grant to the OI. By the first of October, Girkin and fellow petition carriers had organized a "swell of protest" and garnered 1,300 signatures from area residents. Tribune staff writer and local historian and folk culture aficionado Jim Lair, a native of southern Arkansas, declared that the local "protest movement" against this "proposed waste" had been a "refreshing experience" for him, since he had "witnessed people getting involved in what they feel is right and certainly we need more citizen involvement if we are going to turn around much of the thinking that is present in our nation today." 45

The local protest movement combined with emerging Republican political campaigns in Arkansas to stir a swarm of controversy around the OI and its federal grant, which even prompted an FBI investigation into the organization's affairs. Accordingly, Governor Clinton quickly sought to distance his administration from the issue, promising local residents that "I'll stop the CETA grant to the Ozark Institute" immediately upon any findings of wrongdoing. Aside from a handful of citations regarding organizational signatures on federal paperwork by the wrong personnel, the FBI found no irregularities or corruption within the OI. Nevertheless, Governor Clinton, who was neck-deep in an increasingly fragile re-election campaign, ultimately

\footnotetext{
${ }^{44}$ Clyde Payne, “That Damyankee Traitor named U.S. Grant,” Eureka Springs Times-Echo, October 23, 1980. Ironically, Carroll County, along with other parts of northwestern Arkansas, was bitterly divided between proConfederate and pro-Union sympathy during the Civil War. See C.J. Miller, "Carroll County," Encyclopedia of Arkansas History and Culture (http://www.encyclopediaofarkansas.net/encyclopedia/entrydetail.aspx? entryID=752).

${ }^{45}$ Jim Lair, "Reflections of an Outlander" column, Carroll County Tribune, October 3, 1980.
} 
denied the state's necessary approval for the OI's 1981 CETA grant and refused to comment further on the matter. Faced with the firestorm of public ridicule and stripped of most of its funding, the OI was eventually forced to close its doors altogether in $1982 .{ }^{46}$

By 1980, the populist ethic had undergone a remarkable transformation in the Arkansas Ozarks. Rural hill folks had entered the ever-changing 1960s certainly suspicious, like most Americans, but still hopeful in the power of a "people's government" to help improve their lives. Government reformers' unflinching faith in industrial growth and development, however, ensured that the unevenness between the rural dispossessed and the affluent beneficiaries of the New Ozarks political economy grew wider and wider. Development reformers' confidence in the merits of America's political tradition of "local control" also guaranteed that local and regional elites possessed the privileges of administering government programs and of framing the dominant themes in public debates about the social programs' "failures" and "successes." This meant that the federal government and its "bureaucracy" generally absorbed most of the blame for the far more numerous "failures," while local officials' and area business leaders' visionary efforts and hard work, despite the heavy infusions of government assistance, received the credit for the "successes" in places like Washington and Benton Counties and towns like Mountain Home and Harrison.

Meanwhile, widespread disappointment with the limits of development programs fused with growing animosities over the federal government's more "grassroots" oriented efforts that

\footnotetext{
46 "Clinton Visits County in Area Campaign Swing," Carroll County Tribune, September 12, 1980; "Ozark Institute Denied 1981 Grant," Fort Smith Southwest Times Record, October 7, 1980. Republican opponent Frank White made the Ozark Institute controversy an important part of his ultimately successful gubernatorial campaign against Clinton in 1980, "scor[ing] the most stunning upset in Arkansas political history." Clinton, however, was elected once again in 1982 after apologizing for the mistakes of his first term in office and vowing to Arkansas voters that he would no longer try to "lead without listening." Dianne D. Blair, "William Jefferson Clinton 1979-1981, 19831992," in The Governors of Arkansas: Essays in Political Biography, edited by Timothy P. Donovan, et al., (Fayetteville: University of Arkansas Press, 1995), 264-265.
} 
sought to address social and economic issues "from the bottom up." Frustrated elites who were bypassed by these more "direct" government efforts quickly established a powerful conservative discourse of opposition that tended to make far better use of tying their messages to the region's popular sensibilities than the reformers who intended to help-despite the major political deviations from the historic roots of traditional economic populism in the rural Ozarks. The constant and ultimately successful assaults by local officials to gain control of the social programs themselves or dismantle them altogether persistently impaired progressive government efforts. At the same time, paternalistic and largely out-of-touch reformers' inabilities to connect with the rural folks they aimed to help limited any hopes of mounting an effective populist defiance to counter the anti-government claims of conservative New Ozarks elites. Amid this vacuum in the discourse, then, many Ozarkers came to agree with Ronald Reagan's contention that "Government is not the solution to our problems. Government is the problem."47

\footnotetext{
${ }^{47}$ Reagan quoted in Orleck, "Introduction," 7. Of the fifteen primary counties in the Arkansas Ozarks, Reagan won all but two in 1980. Jimmy Carter carried only Izard and Stone counties. By contrast, Carter won all but two counties, Benton and Baxter, in 1976. "1980 Presidential General Election Results-Arkansas," Dave Liep's Atlas of U.S. Presidential Elections (http://uselectionatlas.org/RESULTS/state.php?f=0\&fips=5\&year=1980), accessed April 27, 2014; "1976 Presidential General Election Results-Arkansas," Dave Liep's Atlas of U.S. Presidential Elections (http://uselectionatlas.org/RESULTS/state.php?f=0\&fips=5\&year=1976), accessed April 27, 2014.
} 


\section{Conclusion}

In March 2009, Mountain Home resident Bill Smith—a self-described “Ozark Guru” who proudly claimed "Hillbilly Slang" as his primary language - and other conservative political activists in the region advertised the newly-founded Ozark Tea Party's plans to host a local rally on April 15. It was to be held in conjunction with the national Fair Tax movement's "Nationwide Tax Day Tea Party," a demonstration that was being organized to call for the abolition of all federal income taxes. An Air Force veteran, an ordained minister, and the owner of a business consulting firm who had come to the Ozarks most recently from Kansas, Smith described his and fellow tea partiers' mission as one aimed at "upholding the rights granted by God \& guaranteed by the U.S. Constitution, traditional family values, 'republican' principles/ideals, transparent \& limited government, free markets, liberty, school choice \& individual freedom." Vowing to be the "silent majority no more" and asserting that "revolution is brewing," Ozark Tea Party organizers explained that they were organizing this event for the purposes of "supporting the free market and honoring our veterans," and they asked participants to bring homemade signs, tea bags, and American flags with them to the rally. "Just as our founding fathers did at the Boston Tea Party," said Smith, "Americans from across the country are coming together on April $15^{\text {th }}$ to protest the Governments [sic] wasteful spending." Tea partiers in the Ozarks also organized similar events in the towns of Fayetteville, Rogers, and Springdale in the northwestern corner of the state. ${ }^{1}$

\footnotetext{
${ }^{1}$ Bill Smith, "Ozark Tea Party-Mountain Home, Arkansas," advertisement posted at FairTaxNation.com, March 26, 2009, (http://www.fairtaxnation.com/profiles/blogs/ozark-tea-party-mountain-home), accessed April 8, 2014; "Dr. Bill Smith," biographical profile posted at https://www.linkedin.com/in/ozarkguru, accessed April 8, 2014;

“Resume: Dr. Bill Smith (Ozark Guru),” posted at http://agora-assoc.com/smithresume.html, accessed April 8, 2014.
} 
Fellow conservative activist and Mountain Home resident Richard Caster, the eighteenyear-old son of entrepreneurial parents who had moved to the New Ozarks town from California during the 1970s, likewise urged the region's residents to come to the realization that "every Generation needs a Revolution," as the venerable Thomas Jefferson so wisely put it, and that "this is our time, this is our American Revolution." Caster, who recalled his first taste of political activism as a nine-year-old making Bush-Cheney campaign buttons with his crayons, worked as a manager at his father's chain restaurant and was pursuing a business degree at the local community college, hoping to someday "open an insurance company, retire at 50 and travel the country in an RV." He insisted that "The question is, will we take this opportunity and fight to bring America Back to its founding Principles of limited Government, A Free Market, and a Capitalistic system." "Or will we let the Far Left Liberals in our nation continue to take us down the road to socialism [?]" he asked. A devoutly conservative Catholic who believed that "We need to get a backbone back in our faith and back in politics," Caster hoped that the tea party rally, along with others like it throughout the nation, would begin to help rescue America from its dangerous path of national decline. "If your [sic] ready for Real change please join us," he pleaded. $^{2}$

According to their own count, about 1,500 people from northern Arkansas and southern Missouri attended the Ozark Tea Party's tax day rally at the town square in Mountain Home, located, somewhat ironically, only a few miles from two of the federal government's New Dealera dams and lakes. When the young organizer Richard Caster took to the stage to kick off the

\footnotetext{
${ }^{2}$ Smith, "Ozark Tea Party—Mountain Home, Arkansas"; Aprille Hanson, "Student Begins His Political Career in Mountain Home," Arkansas Catholic.org, December 4, 2010 (http://www.arkansas-catholic.org/news/article/2371), accessed April 8, 2014; "Mary Ann Caster, Real Estate Agent, Gilbert Realty Co.," GilbertRealty.com (http://www.gilbertrealty.com/marylist.htm), accessed April 8, 2014.
} 
event and asked those in attendance how they were doing, one man hollered out above the rest of the noisy crowd, "We're broke!" After a few introductory remarks from Caster, Pastor Sam Baily of the Twin Lakes Baptist Church led the tea party protestors in prayer and declared that "liberty is a gift from God." Then, they sang the National Anthem and recited the Pledge of Allegiance before a young woman read a patriotic poem to honor the veterans of the U.S. military. Subsequently, Mickey Pendergrass, the owner of the local Century 21 real estate firm in Mountain Home and a local political leader, gave a speech in which he demanded that federal and state lawmakers immediately get to work on legislation to cancel all capital gains and estate taxes. Finally, tea party Republican Karen Hopper, the local state representative, an administrator at Mountain Home's state-funded community college, and a board member of the area chamber of commerce, topped the day off with a fiery speech. "Like Samuel Adams and Paul Revere who participated in the first great tea party," Hopper declared, "we are tired of politicians who believe that spending will solve all of our problems." "Like them, we are tired of a government that punishes those who practice responsible financial behavior and rewards those who do not," she continued. "Think about it, maybe our congressmen and congresswomen will think twice about how they vote, because that last tea party sparked a revolution."”3

Like the populist movement that had shaped rural Ozarkers' attitudes about government during the late nineteenth and early twentieth centuries, tea partyism bore strong marks of antiestablishmentarianism. But this was not the same anti-establishmentarianism that had once inspired the "damn-guvment" defiance of the backcountry Ozarkers who had joined the Brothers

\footnotetext{
3 "Ozark Tea Party in Mountain Home AR," video posted at http://www.youtube.com/watch?v=9R0OzTSaH6Q, accessed April 8, 2014; "Karen S. Hopper," State House of Representatives profile posted at http://www.arkansashouse.org/member/232/Karen\%20S.-Hopper, accessed April 8, 2014.
} 
of Freedom, or the Bruces and their moonshining comrades, or the Harps and their fellow draft resisters, or the smallholders on Hutchinson Mountain who resisted the government's tick eradication program, or the small farm families who hoped that the New Deal's expanded liberal state might finally bring economic justice to rural and working-class Americans. Twenty-firstcentury tea partyism, in fact, held much more in common with the industrial- and agribusinessoriented New Ozarks vision that those backcountry populists had adamantly resisted for so long. Emerging most prominently from "growth centers" like Mountain Home and the economic oasis of Washington and Benton counties, it was conservative businessmen and their supporters in the twenty-first century who led a tea party movement that aimed to preserve the local control of regional economic elites in the low-wage industrial-, tourism-, and agribusiness-based order that had finally replaced smallholder farm life in the Ozarks during the post-World War II era. Tea partyism, then, sprang from a newer fountain of "damn-guvment" defiance, one akin to the more recent dynamics of resistance that was represented by the elite-led opposition in the Ozarks to the federal government's war on poverty during the 1960s and 1970s. Indeed, this twenty-firstcentury defiance and its particular agenda of political resistance sought to tear down a number of the same government powers that the region's late-nineteenth- and early-twentieth-century rural forefathers had demanded and helped create.

The dynamics of rural defiance against government power in the Arkansas Ozarks during the late nineteenth and early twentieth centuries, in fact, differed very markedly from that of the late twentieth and early twenty-first, despite the prevalence of a stereotyped cultural discourse that tended to suggest otherwise. When rural Ozarkers entered the twentieth century, they were not divorced from the rest of the world in isolated mountain hollers but, rather, were right in the thick of Gilded Age economic, social, and political developments that characterized much of the 
broader American experience. Faced with rising inequalities and rural and working-class dispossession, backcountry Ozarkers called on the "people's government" to acquire brand new roles, particularly interventions in the capitalist economy that they hoped would safeguard the American ideals of fairness, equal opportunity, and liberty. Their particular resistance to government power did not reflect an ideological or cultural aversion to the institution of government itself. Instead, they resented an imbalanced status-quo system of government that they believed had been high-jacked by the rich and powerful few to selfishly serve their own "special interests" at the expense of commoners like themselves.

Contrary to popular imagery of rural mountaineers clashing with government authorities in conflicts that primarily pitted invasive outsiders against homogenous hill people who wanted nothing more than to be left alone, most confrontations over government power in the Ozarks had more to do with local animosities between the region's well-to-do and well-connected elites and its poor and middling inhabitants in the backcountry. Late-nineteenth- and early-twentiethcentury backcountry people's attitudes toward and acts of defiance against government authority more often than not were born from their resentment of town businessmen, larger and more prosperous farmers, and other local elites who wielded disproportionate control of government power in the region and used it to advance a New Ozarks vision of industrial development and agricultural centralization that burdened and effectively eroded the viability of smallholder farm communities. The American liberal state's typical delegation of authority and resources to regional elites' "local control" persistently obstructed rural populists' demands for a "just" government and, thus, helped ensure the perpetuation of this intra-regional conflict over government power throughout the first half of the twentieth century. 
By contrast, the conservative laissez-faire ideological and cultural critique of government power that is commonly associated with the region today arose more recently as a strong political discourse amid a New Ozarks society and economy that had supplanted small-scale family farm life during the second half of the twentieth century. After those thousands of poor and middling smallholders who were most disposed to backcountry populism emptied their rural Ozarks communities during the World War II and postwar decades, a significant wave of "population replacement" by non-natives mostly from the urban and suburban Midwest began sweeping the region by the 1970s, a demographic change that has persisted largely unabated into the second decade of the twenty-first century. During the 1940s and 1950s, with the exception of prosperous Washington and Benton counties on the Springfield Plain, the region lost nearly onethird of its population. Between 1960 and 1990, however, while many rural natives continued to leave, the large influx of Midwestern newcomers produced overall population increases of at least twenty-five percent for all but one of the fifteen primary Ozarks counties. Baxter County, in addition to Washington and Benton counties, experienced aggregate population gains that exceeded two-hundred percent. Only Searcy County, deep in the rugged heart of the region, continued to show population losses. These "fundamental demographic, social, and even cultural transformations" in the Ozarks during the second half of the twentieth century, asserts historian Brooks Blevins, should prompt "a reevaluation of the meaning of rural community."4 Indeed, this reevaluation should include a reconsideration of what this significant change means for our narratives about rural political culture and sentiments about government.

\footnotetext{
${ }^{4}$ Brooks Blevins, "Retreating to the Hill: Population Replacement in the Arkansas Ozarks," Agricultural History 74 (Spring 2000): 475-488, quotation on 476; Blevins, Hill Folks, 193-205.
} 
The post-smallholder farming society and economy of the New Ozarks lured non-native entreprenuers to light-industrial, agribusiness, and tourism-based business ventures primarily in the region's growth centers but also to "cheap" real-estate investments throughout the depopulated countryside. New in-migrants to the Ozarks, a large number of whom were also retirees, frequently pointed to some "combination of aesthetic appeal, low-cost living, inexpensive land and housing, and absence of severe pollution and criminal activities," in addition to "low taxes," as key attractions. ${ }^{5}$ Some newcomers represented the American counterculture movement, and these idealistic "back-to-the-landers" came to the Ozarks seeking an "unspoiled" and "natural" abode. But far more in-migrants arrived to the region harboring much more "conservative" lifestyles and ideals. During this era of suburbanization and "white flight" from American cities, the "lilly whiteness" of the Ozarks served as a magnet to many middle-class whites from the Midwest who were uncomfortable with the increased racial and cultural diversity of their urban neighborhoods during the postwar decades. Like the back-tothe-landers - albeit obviously for different reasons - many of these "conservative" Midwesterners were drawn to the region, at least in part, by a romanticized image of Ozarks isolation and "heritage." Seeking to escape a "liberalizing" America, they joined a number of native New Ozarks elites to forge a rapidly-growing New Right, government-loathing political culture in the region by the turn of the twenty-first century. ${ }^{6}$ Rural Ozarks stereotypes

\footnotetext{
${ }^{5}$ Blevins, "Retreating to the Hill," 476, 480.

${ }^{6}$ Though many contemporary observers, including historians, have found it "tempting to write off the influence the new settlers had on the traditional lives of Ozark people," Brooks Blevins emphasizes the non-native newcomers' major contributions to "significant alterations" in the region's cultural and political environment during the second half of the twentieth century. He notes especially how this in-migration of Midwesterners, as well as the outmigration of rural natives, is vital to understanding how the Ozarks (with the exception of some eastern counties where local Democrats continue to win elections) became "a Republican stronghold" during the late twentieth and early twenty-first centuries. Blevins, Hill Folks, 204-206.
} 
notwithstanding, change had shaped new sentiments about government power in the Arkansas hill country.

Though "the modern Ozarks bears little resemblance to the region before World War II," historians have generally neglected to account for this fundamental change in their narratives about rural political culture and rural people's experiences with and attitudes about government power. $^{7}$ While historians such as Bethany Moreton and Darren Dochuk emphasize a historical continuum that links today's New Right conservatism back to a late-nineteenth and earlytwentieth-century rural culture, they overlook major nuances that reveal far more change than their works allow for. In particular, they miss the significance of the populist ethic and local conflicts that, more than anything, shaped many of rural Ozarkers' biggest stands against government power during the first half of the twentieth century.

The socioeconomics of the smallholder family farm society that had birthed and sustained rural Ozarkers' populist defiance in the late nineteenth and first half of the twentieth centuries has now been extinct for the better part of fifty years. This fact, especially when considered with the transformative demographic changes that have occurred in the Ozarks since the middle of the twentieth century, may seem to indicate that the likelihood is slim to none for a resurgence in the region's foreseeable future of a populist ethic that sees an important role for government in helping to curb and mitigate inequalities. The ever-strengthening conservative, antigovernment political culture in the region today certainly seems to suggest so. But if this study has shown us anything, it is that circumstances and ideas change, even if they may go unnoticed or are misunderstood by observers. Furthermore, even in this unlikey recent political climate, many rural Ozarkers have at times demonstrated a willingness to go against the grain of their

\footnotetext{
${ }^{7}$ Blevins, Hill Folks, quotation on 217.
} 
conservative political leaders' ideology, demanding that government services respond to their needs, regardless of "limited government" and "fiscally conservative" principles.

In late 2011 and 2012, for instance, hundreds of rural Ozarkers in small towns and communites across the region organized in protest when the financially-distraught US Postal Service announced that it planned to close "roughly a third" of Arkansas's post offices, primarily in rural areas that it claimed had "too little workload" and produced too little revenue to justify their operating costs. Many rural Ozarkers met at small-town community centers, churches, and on front porches to draw up petitions, insisting that government officials do something to keep their federal postal services available. Others wrote letters, made phone calls, or visited their political representatives to voice their opposition to the Postal Service's decision. Stanley Morrison, a fifty-nine-year-old logger and a local justice of the peace in Stone County who helped lead the protest to keep his community's post office open, explained that "There are those who have been downtrodden so long, they can't get back up. And there are others who've been downtrodden so long they decide to fight back." He and his community and others like them in the rural Ozarks intended to stand among the latter. ${ }^{8}$

The "swift" swarm of rural protest against rural post office closures quickly pressured many of the region's conservative political leaders to take a stand on the issue, including firstterm US Senator John Boozman. Boozman, Arkansas's second Republican Senator since Reconstruction, had been elected with 58 percent of the vote amid the state's anti-Obama tea party insurgency in the 2010 mid-term election. Boozman had unseated the self-proclaimed "independent" incumbent, Blanche Lincoln, a Democrat who had served in the US Senate since

\footnotetext{
${ }^{8}$ Campbell Robertson, “A Fight for Post Offices and Towns' Souls," New York Times, January 4, 2012 (http://www.nytimes.com/2012/01/05/us/arkansas-towns-with-a-post-office-and-little-else-fightclosings.html?pagewanted=all\&_r=0).
} 
1998, by painting her as a Big Government liberal—a supporter of "spending, spending, spending"- and tying her to the grossly unpopular president. When rural Ozarkers flooded Boozman's office with letters and petitions demanding that he fight the US Postal Service to keep the offices in their communities open, the conservative Senator decided to make an "apparent departure from small-government orthodoxy." A number of fellow conservatives claimed that "People make choices about where they live and how they navigate their lives" and argued that "Congress should let the Postal Service make choices as well, like any business would when times change and it starts losing money.” But the popular pressure on Boozman quickly put him to work on proposing legislation that would have banned the Postal Service from closing any rural post office in which a local community did not have access to another within ten miles. "There are times when it's not as profitable," Boozman explained his unlikely position, "but it's important to provide that service." In the end, though a few offices ended up closing, the groundswell of popular protest convinced the US Postal Service to keep most rural post offices open on a part-time basis. ${ }^{9}$

Though the region's small farm society that once bore the populist ethic has long faded into the pages of history, the recent protest against rural post office closures is but one example that seems to suggest that many rural Ozarkers' penchant for analyzing the personal and local consequences of unequal social, economic, and political power may be just as strong today as it was for those defiant hill folks in the late nineteenth and early twentieth centuries. As historian and activist Michael Stewart Foley has recently shown, strong grassroots movements can emerge and become very effective, even in the most unlikely political enviornments, particularly when

\footnotetext{
${ }^{9}$ Ibid.; “John Boozman for Senate Campaign News Conference, July 6, 2010,” C-SPAN.org (http://www.cspan.org/video/?294383-1/john-boozman-senate-campaign-news-conference-).
} 
people determine at the local level that the forces of inequality pose immediate threats to the well-being and aspirations of their families and communities. ${ }^{10}$ Future movements that can succeed, then, in personalizing and localizing the real-life detriments of twenty-first-century America's glaring social and economic inequalities in rural communities - like the populist ethic of smallholder farmers did in the late nineteenth and twentieth centuries - may have the potential to ignite new waves of populist defiance and possibly help change rural sentiments again about the role of government in the twenty-first-century Ozarks.

The failures of outside poverty warriors to tap the populist ethic in the rural Ozarks in the 1960s and 1970s make it abundantly clear that homegrown, grassroots activism and leadership participation are essential for the hopes of future movement building. But outside refomers should not write the region off. Canadian-born "furriner" Issac McCracken's seminal role in the farmers' movement in the 1880 s and 1890 s, and, for that matter, the strong influence of recent in-migrants from the urban and suburban Midwest in contemporary Ozarks tea partyism, teach us that there is significant room for outside activism and organizational skills. The difference between the failures of federal poverty reformers to mobilize rural Ozarkers, on the one hand, and the successes of the farmers' revolt and today's tea partiers, on the other, is the latter movements' ability to relate at a personal and local level to rural people's lives, values, and frustrations; hence, they succeeded in convincing rural people that their movements offered the best diagnoses of and plausible solutions to their problems.

This study's close look at rural Ozarkers' experiences with and attitudes about government power during the long twentieth century should also force historians to entertain

\footnotetext{
${ }^{10}$ Michael Stewart Foley, Front Porch Politics: The Forgotten Heyday of American Activism in the 1970s and 1980s (New York: Hill and Wang, 2013).
} 
new discussions about why liberal states" "progressive" programs have often failed to win the support of the people they intended to help, especially in rural areas. Historians who follow James C. Scott's "high modernism" model have done important work in exposing the need for policymakers to avoid cookie-cutter approaches in devising and administering programs and in shedding light on how their efforts would likely have fared much better if they had paid closer attention to practical "local knowledge" about grassroots problems and potential solutions. Nevertheless, their indictments of distant, out-of-touch policymakers in centralized bureacracies tend to overlook important inequalities, competing interests, and uneven access to government power at regional and local levels. Contrary to the conventional view of rural resistance against government power as an outsiders-versus-locals paradigm, the story in the Ozarks was primarily one of local conflict. Namely, it represented a clash between well-to-do New Ozarks elites who controlled government programs and administered them in ways that promoted their vision of industrial development and centralized agriculture and the dispossessed smallholders in the backcountry who rarely received the security and improvements they were promised.

Much like the patterns of "governmentality" in Indonesia's Sulawesi highlands and other rural regions throughout the world, the stories of rural Ozarkers' experiences with government power during the long twentieth century provide important lessons for architects of contemporary and future liberal state reform efforts, particularly those that seek to address certain social and economic inequalities. A keen understanding of the local and regional dynamics of power and competing interests at the ground level is essential. In the Ozarks, efforts by the federal government to improve peoples' lives since the late nineteenth century were always subjected to compromises and negotiations with local elites who ensured that new sources of government power advanced agendas that served their own interests and thwarted the 
programs' original intentions to reach the disadvantaged. Thus, interventions by the American state that aimed to redress social and economic problems most often led to unintended consequences that actually made the region's uneven opportunities and inequalities even worse. The lessons of historical experience, then, seem clear. Reform efforts that seriously aim to alleviate poverty and improve the lives of common and poor people must circumvent the elitecontrolled local structures of power that truly sustain social and economic inequalities on the ground. The Lyndon Johnson administration's attempts in the 1960s to launch a war against poverty at the grassroots came the closest in attempting to bypass local and regional elites. But the federal government's flirting with "maximum feasible participation," which aimed to put significant control of the programs in the hands of the poor themselves instead of traditional systems of local governance, proved short-lived as the administration caved under the massive political pressure of elites who cried afoul at such a "radical" violation of local control. Moreover, those outside government activists who came to the region to help fight poverty in local hill communities failed to win the support of the people they intended to help, dooming any chances of mobilizing a significant front that could challenge local power structures. Many poverty warriors did come to recognize the unneveness of local power as a primary source of inequality, but they distrusted poor Ozarkers nearly as much as they did their elite antagonists. Assuming that hill folks were culturally backward and automatically resistant to change, poverty warriors believed that the rural poor should merely follow reformers along the path to "progress." A reform movement that better understood the historical dynamics of the populist ethic in the rural Ozarks and made a serious effort to build a truly grassroots movement may well have turned out differently. 
The case of the rural Ozarks suggests, then, that any hopes of utilizing the liberal state to successfully combat poverty and promote a more democratic political economy must do two things simultaneously. First, successful reform movements must understand on a "microscopic" level how social, economic, and political power is held in localities and regions and ensure that their programs reach the dispossessed populations they were intended for. They must go around and avoid "diluting" compromises with those structures of local power that shape real-life inequalities. While this prescription is easy to write for an "armchair thinker" such as myself, it is important to realize that any course of action that bypasses and, in fact, is primarily aimed at curtailing the control of local elites would invevitably ignite the "total," unlimited resistance of the powerful and resourceful defenders of the status quo. Any hopes of overcoming such formidable opposition would require an immense, impassioned, and largely air-tight popular front that has its sights locked in on these local sources of unevenness and is fully determined to correct them. To achieve this second component, reformers must work to bring out the populist sentiments embedded deep in dispossessed populations by focusing on those local and regional perpetrators that sustain and promote the particular inequalities that threaten their families' and communities' economic security and aspirations for future prosperity. A deeper understanding of and emphasis on such local dynamics should prompt reformers to shun many old and baseless stereoptypes about the people they aim to help and, as a result, encourage them to prioritize the grassroots inclusiveness that must exist to build a popular front that has any hopes of successfully challenging the mighty defenders of the status quo. Never before have all of these parts come together in the rural Ozarks, even in the seemingly fertile and most likely environment of the late nineteenth and early twentieth centuries. But what good is history if it 
does not teach us about failures and successes in the past that might help us change our own lives and times for the better? 


\section{Bibliography}

\section{Manuscript Collections:}

Arkansas History Commission, Little Rock, Arkansas

Ben Laney Papers

Carl E. Bailey Papers

George Washington Hayes Papers

Harvey Parnell Papers

Sidney McMath Papers

Cleburne County Courthouse, Heber Springs, Arkansas

Circuit Court Records

Personal Property Tax Records

Hendrix College Archives and Special Collections, Conway, Arkansas

Wilbur Mills Papers

Independence County Courthouse, Batesville, Arkansas

Circuit Court Records

Personal Property Tax Records

Missouri State University Special Collections, Springfield, Missouri

Center for Ozarks Studies Records

National Archives, College Park, Maryland

General Records of the Department of Commerce (RG 40)

U.S. Bureau of Investigation Case File Archives (RG 65)

National Archives, Fort Worth, Texas

U.S. District Court Records (RG 21)

Searcy County Courthouse, Marshall, Arkansas 
Personal Property Tax Records

University of Arkansas at Little Rock Special Collections, Butler Center for Arkansas Studies, Little Rock

Winthrop Rockefeller Papers

University of Arkansas Special Collections, Fayetteville, Arkansas

Billy James Hargis Papers

Clyde T. Ellis Papers

Orval Faubus Papers

University of Central Arkansas Archives, Conway, Arkansas

Arkansas VISTA Collection

\section{Government Publications:}

Dinwiddie, R.R., and W. Lenton. "Notes on the Cattle Tick and Tick Fever of Cattle." Bulletin No. 101. Fayetteville: Arkansas Agricultural Experiment Station, 1908.

Kennedy, John F. “Address by President John F. Kennedy, Dedication of Greer's Ferry Dam, Heber Springs, Arkansas, October 3, 1963.” Reprinted in the program of the Greer's Ferry Dam $50^{\text {th }}$ Anniversary Dedication Ceremony. U.S. Army Corps of Engineers. October 3, 2013.

Ozarks Regional Commission. Ozarks Region: An Opportunity for Growth. Washington, DC: Ozarks Regional Commission, 1967.

--------. Ozarks Regional Commission Economic Development Action Plan .Washington, DC: Ozarks Regional Commission, 1976.

Ozarks Regional Commission Listing: Technical Assistance Projects, Demonstration Projects, Supplemental Grant Projects Completed or in Progress, FY 1968-FY 1979. N.p., N.d. (Available at John Vaughan Library, Northeastern Oklahoma State University, Tahlequah, Oklahoma).

“Tick Eradication Laws.” Bulletin No. 160. Fayetteville: Arkansas Agricultural Experiment Station, 1919.

U.S. Congress. Congressional Record, S1776. February 18, 1969. 
U.S. Department of Agriculture. "Prices Received by Farmers for Beef Cattle: United States and States Monthly and Annual Average, 1909-59." Statistical Bulletin No. 265. Washington, D.C.: USDA Agricultural Marketing Service, 1960.

--------. United States Department of Agriculture Yearbook, 1921. Washington, D.C.: Government Printing Office, 1922.

U.S. Department of Interior. Office of the Census. Seventh Census of the United States, 1850: Population. Manuscript Schedules.

--. Seventh Census of the United States, 1850: Slaves. Manuscript Schedules.

--. Eighth Census of the United States, 1860: Population. Manuscript Schedules.

--------. Eighth Census of the United States, 1860: Slaves. Manuscript Schedules.

--------. Ninth Census of the United States, 1870: Population. Manuscript Schedules.

---------. Tenth Census of the United States, 1880: Population. Manuscript Schedules.

---------. Twelfth Census of the United States, 1900: Population. Manuscript Schedules.

---------. Thirteenth Census of the United States, 1910: Population. Manuscript Schedules.

-. Fourteenth Census of the United States, 1920: Population. Manuscript Schedules.

-. Fifteenth Census of the United States, 1930: Population. Manuscript Schedules.

---------. Sixteenth Census of the United States, 1940: Population. Manuscript Schedules.

U.S. Department of Justice. Annual Report of the Attorney General of the United States, 1899. Washington, D.C.: Government Printing Office, 1899.

U.S. Department of War. Final Report of the Provost Marshall to the Secretary of War on the Operation of the Selective Service to July 15, 1919. Washington: Government Printing Office, 1920.

Vincenheller, W.G. "Cattle Tick Eradication in Northwest Arkansas." Bulletin No. 93. Fayetteville: Arkansas Agricultural Experiment Station, 1907.

\section{Court Records:}


Adkisson v. State. 1920. Arkansas Supreme Court Briefs and Records. UALR/Pulaski County Law Library Special Collections, Little Rock, Arkansas.

Bruce v. State. 1900. Arkansas Supreme Court Briefs and Records. UALR/Pulaski County Law Library Special Collections, Little Rock, Arkansas.

Cazort v. State. 1917. Arkansas Supreme Court Briefs and Records. UALR/Pulaski County Law Library Special Collections, Little Rock, Arkansas.

Davis v. State. 1916. Arkansas Supreme Court Briefs and Records. UALR/Pulaski County Law Library Special Collections, Little Rock, Arkansas.

State v. Bliss Adkisson, et al. 1919. Cleburne County Circuit Court. Cleburne County Courthouse, Heber Springs, Arkansas.

State v. George Schroggins. 1915. Independence County Circuit Court. Independence County Courthouse, Batesville, Arkansas.

State v. Hardy Adkisson. 1920. Cleburne County Circuit Court. Cleburne County Courthouse, Heber Springs, Arkansas.

State v. Leo Martin, Jno Penrod, and Thos. Adkisson. 1919. Cleburne County Circuit Court. Cleburne County Courthouse, Heber Springs, Arkansas.

State v. Matt Simmons, Jess Blakey, Columbus Blakey, and James Blakey. 1919. Cleburne County Circuit Court. Cleburne County Courthouse, Heber Springs, Arkansas.

State v. Paul Curtis. 1915. Independence County Circuit Court. Independence County Courthouse, Batesville, Arkansas.

State v. Paul Curtis. 1916. Independence County Circuit Court. Independence County Courthouse, Batesville, Arkansas.

State v. Paul Curtis, et al. 1922. Preliminary Justice of the Peace Hearing. Independence County Courthouse, Batesville, Arkansas. Transcription of original by Susan Mosier in possession of author.

State v. Tom Adkisson, Bliss Adkisson, and Hardy Adkisson. 1919. Cleburne County Circuit Court. Cleburne County Courthouse, Heber Springs, Arkansas.

U.S. v. Floyd Pumphrey and Argie Pumphrey. 1941. U.S. District Court, Western District of Arkansas, Harrison Division. National Archives at Fort Worth, Texas.

U.S. v. J.N. Pangle and N.E. Pangle. 1940. U.S. District Court, Western District of Arkansas, Harrison Division. National Archives at Fort Worth, Texas. 
U.S. v. John F. Tubbs. 1897. U.S. District Court, Western District of Arkansas. Jacket no. 414. National Archives at Fort Worth, Texas.

U.S. v. Lit Dodson. 1897. U.S. District Court, Western District of Arkansas. Jacket no. 289. National Archives at Fort Worth, Texas.

\section{Newspapers and Periodicals:}

Arkansas Democrat (Little Rock)

Arkansas Farmer (magazine)

Arkansas Gazette (Little Rock)

Arkansas Newsletter (magazine)

Batesville Guard

Baxter Bulletin (Mountain Home)

Carroll County Tribune (Berryville)

Clinton Democrat

Courier-Democrat (Russellville)

Daily Echo (Eureka Springs)

Eureka Springs Times-Echo

Fayetteville Democrat

Globe-Democrat (St. Louis, Missouri)

Harrison Daily Times

Herald-Democrat (Siloam Springs)

Human Events (magazine)

Iola Register (Kansas)

Joplin Globe (Missouri)

Kansas City Star (Missouri)

Laurel Daily Leader (Mississippi) 


\author{
Leslie News \\ Literary Digest (magazine) \\ Marshall Republican \\ Melbourne Times \\ Mountain Echo (Yellville) \\ Mountain View Herald \\ Mountain Wave (Marshall) \\ Newark Journal \\ Newport Weekly Independent \\ Reader's Digest (magazine) \\ Russellville Democrat \\ Sharp County Record (Evening Shade) \\ Southwest Times Record (Fort Smith) \\ St. Louis Post-Dispatch (Missouri) \\ New York Times (New York) \\ Wall Street Journal (New York)
}

\title{
Oral History Interviews:
}

Farmer, Tina. Interview with author. September 19, 2012.

Halstead, Pat. Interview with author. August 30, 2012.

Hurst, Doyle. Interview with Aaron Williams. April 19, 1999. Published in South Shore Memory Project Archives. http://ozarkhistory.com/archive/SouthShore/t-Doyle\%20Hurst.htm.

Jeffery, Brian. Interview with author. July 17, 2010.

Mosier, Susan. Interview with author. May 25, 2010.

Perkins, Bonnie. Interview with author. November 20, 2006. 
Pierson, Harlin. Interview with Tracey Chandler. April 9, 1999. Published in South Shore Memory Project Archives. http://ozarkhistory.com/archive/SouthShore/tHarlin\%20Pierson.htm.

Richey, Nina. Interview with author. August 2, 2012.

Tilley, Jewell. Interview with Brad Goeke. February 10, 1999. Published in South Shore Memory Project Archives. http://ozarkhistory.com/archive/SouthShore/t-J.Tilley.htm.

Thomas, Mildred. Interview with author. May 28, 2010.

\section{Books and Articles:}

Abrahams, Edward H. "Charles Taze Russell and the Jehovah's Witnesses, 1879-1916." American Studies 18 (Spring 1977).

Arsenault, Raymond. "Jeff Davis, 1901-1907." In The Governors of Arkansas: Essays in Political Biography, Second Edition, ed. Timothy P. Donovan, Willard B. Gatewood Jr., and Jeannie M. Whayne. Fayetteville: University of Arkansas Press, 1995.

--------. The Wild Ass of the Ozarks: Jeff Davis and the Social Bases of Southern Politics. Philadelphia: Temple University Press, 1984.

Ayers, Edward L. The Promise of the New South: Life After Reconstruction. New York: Oxford University Press, 1992.

Barnes, Kenneth C. Who Killed John Clayton? Political Violence and the Emergence of the New South, 1861-1893. Durham: Duke University Press, 1998.

Batteau, Allen W. The Invention of Appalachia. Tucson: University of Arizona Press, 1990.

Beckford, James A. The Trumpet of Prophecy: A Sociological Study of Jehovah's Witnesses. New York: John Wiley \& Sons, 1975.

Beeby, James M. "Introduction: Populism in the American South." In Populism in the South Revisited: New Interpretations and New Departures, ed. James M. Beeby. Oxford, MS: University Press of Mississippi, 2012.

---------, ed. Populism in the South Revisited: New Interpretations and New Departures. Oxford, MS: University Press of Mississippi, 2012.

"Benjamin Franklin Taylor." Searcy County Ancestor Information Exchange 16 (February 2007).

Billings, Dwight B., and Kathleen M. Blee. The Road to Poverty: The Making of Wealth and Hardship in Appalachia. New York: Cambridge University Press, 2000.

Billings, Dwight B., Mary Beth Pudup, and Altina L. Waller. "Taking Exception with Exceptionalism: The Emergence and Transformation of Historical Studies of 
Appalachia." In Appalachia in the Making: The Mountain South in the Nineteenth Century, ed. Mary Beth Pudup, Dwight B. Billings, and Altina L. Waller. Chapel Hill: University of North Carolina Press, 1995.

Bissett, Jim. Agrarian Socialism in America: Marx, Jefferson, and Jesus in the Oklahoma Countryside, 1904-1920. Norman: University of Oklahoma Press, 1999.

Blair, Dianne D. "William Jefferson Clinton 1979-1981, 1983-1992." In The Governors of Arkansas: Essays in Political Biography, ed. Timothy P. Donovan, Willard B. Gatewood Jr., and Jeannie M. Whayne. Fayetteville: University of Arkansas Press, 1995.

Blevins, Brooks. Arkansas/Arkansaw: How Bear Hunters, Hillbillies, and Good Ol' Boys Defined a State. Fayetteville: University of Arkansas Press, 2009.

---------. Cattle in the Cotton Fields: A History of Cattle Raising in Alabama. Tuscaloosa: University of Alabama Press, 1998.

. "Considering Regional Exceptionalism: The Case of the Ghost of the Ozarks." Missouri Historical Review 107 (January 2013).

Ghost of the Ozarks: Murder and Memory in the Upland South. Urbana: University of Illinois Press, 2012.

Hill Folks: A History of Arkansas Ozarkers and Their Image. Chapel Hill: University of North Carolina Press, 2002.

. "Retreating to the Hill: Population Replacement in the Arkansas Ozarks." Agricultural History 74 (Spring 2000).

. "Revisiting Race Relations in an Upland South Community: LaCrosse, Arkansas." In History and Hope in the Heart of Dixie: Scholarship, Activism, and Wayne Flint in the Modern South, ed. Gordon E. Harvey, Richard D. Starnes, and Glenn Feldman. Tuscaloosa: University of Alabama Press, 2006.

-------. "The Arkansas Ghost Trial: The Connie Franklin Case and the Ozarks in the National Media," Arkansas Historical Quarterly 73 (Autumn 2009).

-------. "Wretched and Innocent: Two Mountain Regions in the National Consciousness," Journal of Appalachian Studies 7 (Fall 2001).

Brands, H. W. The Strange Death of American Liberalism. New Haven, CT: Yale University Press, 2001.

Brinkley, Alan. The End of Reform: New Deal Liberalism in Recession and War. New York: Vintage Books, 1995.

Campbell, B.T. "Some Early Calf Creek History." Searcy County Ancestor Information Exchange 4 (December 1994).

Cohen, Lizabeth. A Consumers' Republic: The Politics of Mass Consumption in Postwar America. New York: Vintage Books, 2003. 
Compton, Neil. The Battle for the Buffalo River: A Twentieth-Century Conservation Crisis in the Ozarks. Fayetteville: University of Arkansas Press, 1992.

Corcoran, James. Bitter Harvest: Gordon Kahl and the Posse Comitatus: Murder in the Heartland. New York: Viking Penguin, 1990.

Daniel, Pete. Breaking the Land: The Transformation of Cotton, Tobacco, and Rice Cultures since 1880. Urbana: University of Illinois Press, 1985.

DeBlack, Thomas. "“A Harnessed Revolution': Reconstruction in Arkansas.” In Arkansas: A Narrative History, ed. Jeannie M. Whayne, Thomas A. DeBlack, George Sabo III, and Morris S. Arnold. Fayetteville: University of Arkansas Press, 2002.

Dochuk, Darren. From Bible Belt to Sun Belt: Plain-Folk Religion, Grassroots Politics, and the Rise of Evangelical Conservatism. New York: W.W. Norton, 2011.

Donovan, Timothy P., Willard B. Gatewood Jr., and Jeannie M. Whayne, eds. The Governors of Arkansas: Essays in Political Biography, Second Edition. Fayetteville: University of Arkansas Press, 1995.

Dougan, Michael B. Arkansas Odyssey: The Saga of Arkansas from Prehistoric Times to Present. Little Rock: Rose Publishing Company, 1994.

Duncan, Georgena. "'One negro, Sarah...one horse named Collier, one cow and calf named Pink': Slave Records from the Arkansas River Valley." Arkansas Historical Quarterly 69 (Winter 2010).

Dunn, Durwood. Cades Cove: The Life and Death of a Southern Appalachian Community, 18181937. Knoxville: University of Tennessee Press, 1988.

Edwards, Robert. "A Jeffersonian Distillation: The Environment of Politics.” Ozarks Watch 4 (Summer 1990).

Elkins, F. Clark. “Arkansas Farmers Organize for Action, 1882-1884.” Arkansas Historical Quarterly 13 (Autumn 1954).

---------. "The Agricultural Wheel: County Politics and Consolidation, 1884-1885." Arkansas Historical Quarterly 29 (summer 1970).

Eller, Ronald D. “Modernization, 1940-2000.” In High Mountains Rising: Appalachia in Time and Place, ed. Richard A. Straw and H. Tyler Blethen. Urbana: University of Illinois Press, 2004.

---------. Uneven Ground: Appalachia since 1945. Lexington: University Press of Kentucky, 2008. 
Fite, Gilbert C. Cotton Fields No More: Southern Agriculture, 1865-1980. Lexington: University Press of Kentucky, 1984.

Fletcher, John Gould. Arkansas. John Gould Fletcher Series, vol. 3. 1947. Reprint, Fayetteville: University of Arkansas Press, 1989.

Foley, Michael Stewart. Front Porch Politics: The Forgotten Heyday of American Activism in the 1970s and 1980s (New York: Hill and Wang, 2013).

Fones-Wolf, Ken. Glass Towns: Industry, Labor, and Political Economy in Appalachia, 18901930s. Urbana: University of Illinois Press, 2007.

Garbacz, Christopher. “The Ozarks: Recreation and Economic Development.” Land Economics 47 (November 1971).

Gibson, Lanny. The Magic of Scrub Holler: Ozark Mountain Life. N.p. 2001.

Green, James R. Grass-Roots Socialism: Radical Movements in the Southwest, 1895-1943. Baton Rouge: Louisiana State University Press, 1978.

Hahn, Steven. The Roots of Southern Populism: Yeoman Farmers and the Transformation of the Georgia Upcountry, 1850-1890. New York: Oxford University Press, 1983.

Halbrook, William E. "A Review of My Membership in the Farmers Union.” Arkansas Historical Quarterly 15 (Autumn 1956).

Hamilton, Shane. Trucking Country: The Road to America's Wal-Mart Economy. Princeton: Princeton University Press, 2008.

Handley, Lawrence R. "Settlement Across Northern Arkansas as Influenced by the Missouri and North Arkansas Railroad." Arkansas Historical Quarterly 33 (Winter 1974).

Harper, Kimberly. White Man's Heaven: The Lynching and Expulsion of Blacks in the Southern Ozarks, 1894-1909. Fayetteville: University of Arkansas Press, 2012.

Harrell Jr., David Edwin. The Churches of Christ in the Twentieth Century: Homer Hailey's Personal Journey of Faith. Tuscaloosa: University of Alabama Press, 2000.

Harrington, Michael. The Other America. New York: Macmillan, 1962.

Haygood, Tamara Miner. "Cows, Ticks, and Disease: A Medical Interpretation of the Southern Cattle Industry." Journal of Southern History 52 (November 1986).

Hill, Luther B. A History of the State of Oklahoma, Vol. II. Chicago and New York: Lewis Publishing Co., 1910. 
Hobson Jr., Fred C. Serpent in Eden: H.L. Mencken in the South. Chapel Hill: University of North Carolina Press, 1974.

Hodgson, Godfrey. America in Our Time: From World War II to Nixon-What Happened and Why. New York: Doubleday, 1976.

Hofstadter, Richard. The Age of Reform: From Bryan to F.D.R. New York: Vintage Books, 1955.

Hogue, Wayman. Back Yonder: An Ozark Chronicle. New York: Minton, Balch \& Co., 1932.

Holden, Andrew. Jehovah's Witnesses: Portrait of a Contemporary Religious Movement. London: Routledge, 2002.

Hope, Holly. Dip That Tick: Texas Tick Fever Eradication in Arkansas, 1907-1943. Little Rock: Arkansas Historic Preservation Program, 2005.

Iggers, Georg G. Historiography in the Twentieth Century: From Scientific Objectivity to the Postmodern Challenge. Hanover, NH: Wesleyan University Press, 1997.

Isserman, Maurice, and Michael Kazin. America Divided: The Civil War of the 1960s. New York: Oxford University Press, 2008.

Jacoby, Karl. Crimes Against Nature: Squatters, Poachers, Thieves, and the Hidden History of American Conservation. Berkeley: University of California Press, 2001.

Johnson III, Ben F. ““All Thoughtful Citizens': The Arkansas School Reform Movement, 19211930." Arkansas Historical Quarterly 46 (summer 1987).

---------. Arkansas in Modern America, 1930-1999. Fayetteville: University of Arkansas Press, 2000.

---------. John Barleycorn Must Die: The War Against Drink in Arkansas. Fayetteville: University of Arkansas Press, 2005.

Johnston, James. “Arkansas’ 1861 Peace Society.” Arkansas Family Historian 29 (March 1991).

Kazin, Michael. A Godly Hero: The Life of William Jennings Bryan. New York: Anchor Books, 2006.

--------. The Populist Persuasion: An American History. New York: Basic Books, 1995.

Keith, Jeanette. Country People in the New South: Tennessee's Upper Cumberland. Chapel Hill: University of North Carolina Press, 1995. 
--------. Rich Man's War, Poor Man's Fight: Race, Class, and Power in the Rural South during the First World War. Chapel Hill: University of North Carolina Press, 2004.

Kiffmeyer, Thomas. "Looking Back to the City in the Hills: The Council of the Southern Mountains and a Longer View of the War on Poverty in the Appalachian South, 19131970." In The War on Poverty: A New Grassroots History, 1964-1980, ed. Annelise Orleck and Lisa Gayle Hazirjian. Athens: University of Georgia Press, 2011.

---------. Reformers to Radicals: The Appalachian Volunteers and the War on Poverty. Lexington: University Press of Kentucky, 2008.

Kirby, Jack Temple. Rural Worlds Lost: The American South, 1920-1960. Baton Rouge: Louisiana State University Press, 1987.

Kiser, G. Gregory. “The Socialist Party in Arkansas, 1900-1912.” Arkansas Historical Quarterly 40 (Summer 1981).

Lancaster, Guy. “"There Are Not Many Colored People Here’: African Americans in Polk County, Arkansas, 1896-1937.” Arkansas Historical Quarterly 70 (Winter 2011).

Lawson, Alan. A Commonwealth of Hope: The New Deal Response to Crisis. Baltimore: Johns Hopkins University Press, 2006.

Lester, James E. “Sidney Sanders McMath, 1949-1953.” In The Governors of Arkansas: Essays in Political Biography, Second Edition, ed. Timothy P. Donavan, Willard B. Gatewood Jr., and Jeannie M. Whayne. Fayetteville: University of Arkansas Press, 1995.

Levi, Giovanni. “On Microhistory.” In New Perspectives on Historical Writing, ed. Peter Burke. University Park, PA: Penn State University Press, 2001.

Lewis, Helen M., and Edward E. Knipe. “The Colonialism Model: The Appalachian Case.” In Colonialism in Modern America: The Appalachian Case, ed. Helen M. Lewis, Linda Johnson, and Donald Askins. Boone, NC: Appalachian Consortium Press, 1978.

Lewis, Helen M., Linda Johnson, and Donald Askins, eds. Colonialism in Modern America: The Appalachian Case. Boone, NC: Appalachian Consortium Press, 1978.

Lewis, John. A Vista Diary. N.p., 1969-1970. (Available in Arkansas VISTA Collection, University of Central Arkansas Archives, Conway, Arkansas).

Lewis, Ronald L. "Railroads, Deforestation, and the Transformation of Agriculture in the West Virginia Back Counties, 1880-1920." In Appalachia in the Making: The Mountain South in the Nineteenth Century, ed. Mary Beth Pudup, Dwight B. Billings, and Altina L. Waller. Chapel Hill: University of North Carolina Press, 1995. 
--------. Transformation of the Appalachian Countryside: Railroads, Deforestation, and Social Change in West Virginia, 1880-1920. Chapel Hill: University of North Carolina Press, 1998.

Li, Tania Murray. The Will to Improve: Governmentality, Development, and the Practice of Politics (Durham, NC: Duke University Press, 2007).

Lichtenstein, Nelson, and Elizabeth Tandy Shermer, eds. The Right and Labor in America: Politics, Ideology, and Imagination. Philadelphia: University of Pennsylvania Press, 2012.

Link, William A. A Hard Country and a Lonely Place: Schooling, Society, and Reform in Rural Virginia, 1870-1920. Chapel Hill: University of North Carolina Press, 1986.

---------. The Paradox of Southern Progressivism, 1880-1930. Chapel Hill: University of North Carolina Press, 1992.

Malone, David. Hattie and Huey: An Arkansas Tour. Fayetteville: University of Arkansas Press, 1989.

Matusow, Allen J. The Unraveling of America: A History of Liberalism in the 1960s. New York: Harper \& Row, 1984.

McCauley, Deborah. Appalachian Mountain Religion: A History. Urbana: University of Illinois Press, 1995.

McKee, Guian A. “"This Government Is with Us': Lyndon Johnson and the Grassroots War on Poverty." In The War on Poverty: A New Grassroots History, 1964-1980, ed. Annelise Orleck and Lisa Gayle Hazirjian. Athens: University of Georgia, 2011.

Mihm, Stephen. A Nation of Counterfeiters: Capitalists, Con Men, and the Making of the United States. Cambridge, MA: Harvard University Press, 2007.

"MM Taylor, et al vs CT Stone \& AJ Stone, his wife." Searcy County Ancestor Information Exchange 7 (February 1998).

Moneyhon, Carl H. Arkansas and the New South, 1874-1929. Fayetteville: University of Arkansas Press, 1997.

Mosier, Susan. "The 1922 'Tick War': Dynamite, Barn Burning, and Murder in Independence County." Independence County Chronicle 41 (October-January 1999-2000).

Moreton, Bethany. To Serve God and Wal-Mart: The Making of Christian Free Enterprise. Cambridge: Harvard University Press, 2009. 
Morgan, W.S. History of the Wheel and Alliance and the Impending Revolution. Fort Scott, KS: J.H. Rice and Sons, 1889.

Murphy, Karen Potter. Higden ...A Place in the Heart: Life before Greer's Ferry Lake. N.p: Create Space Independent Publishing Platform, 2013.

Murphy, Robert T. "The Regional Commission System." Public Administration Review 33 (March-April 1973).

Niswonger, Richard L. "James Paul Clarke, 1895-1897." In The Governors of Arkansas: Essays in Political Biography, Second Edition, ed. Timothy B. Donovan, Willard B. Gatewood Jr., and Jeannie M. Whayne. Fayetteville: University of Arkansas Press, 1995.

--------. “William F. Kirby, Arkansas's Maverick Senator.” Arkansas Historical Quarterly 37 (Fall 1978).

O'Conner, Alice. Poverty Knowledge: Social Science, Social Policy, and the Poor in TwentiethCentury U.S. History. Princeton: Princeton University Press, 2001.

Orleck, Annelise. "Introduction: The War on Poverty from the Grass Roots Up." In The War on Poverty: A New Grassroots History, 1964-1980, ed. Annelise Orleck and Lisa Gayle Hazirjian. Athens: University of Georgia, 2011.

Orleck, Annelise, and Lisa Gayle Hazirjian, ed. The War on Poverty: A New Grassroots History, 1964-1980. Athens: University of Georgia, 2011.

Payton, Leland, and Crystal Payton. Damming the Osage: The Conflicted Story of Lake of the Ozarks and the Truman Reservoir. Springfield, MO: Lens \& Pen Press, 2012.

Perkins, Blake. "Race Relations in Western Lawrence County, Arkansas." Big Muddy: A Journal of the Mississippi River Valley 9.1 (2009).

Pierce, Daniel S. Corn From a Jar: Moonshining in the Great Smoky Mountains. Gatlinburg, TN: Great Smoky Mountains Association, 2013.

Pierce, Michael. "Orval Faubus and the Rise of Anti-Labor Populism in Northwestern Arkansas." In The Right and Labor in America: Politics, Ideology, and Imagination, ed. Nelson Lichtenstein and Elizabeth Tandy Shermer. Philadelphia: University of Pennsylvania Press, 2012.

Piland, Shirley Carter, ed. A History of Ozark County, 1841-1991. Gainesville, MO: Ozark County Genealogical and Historical Society, 1991.

Pitcaithley, Dwight T. Let the River Be: A History of the Ozark's Buffalo River. Santa Fe: Southwest Cultural Resources Center of the National Park Service, 1978. 
Postel, Charles. The Populist Vision. New York: Oxford University Press, 2007.

Pudup, Mary Beth, Dwight B. Billings, and Altina L. Waller, eds. Appalachia in the Making: The Mountain South in the Nineteenth Century. Chapel Hill: University of North Carolina Press, 1995.

Rafferty, Milton D. The Ozarks: Land and Life, Second Edition. Fayetteville: University of Arkansas Press, 2001.

Randolph, Vance. The Ozarks: An American Survival of Primitive Society. New York: Vanguard Press, 1931.

Rayburn, Otto Ernest Rayburn. Ozark Country. New York: Duell, Sloan \& Pearce, 1941.

Roberts, Charles Kenneth. "Client Failures and Supervised Credit in the Farm Security Administration.” Agricultural History 87 (Summer 2013).

Robins, Ruby. “Nine Decades of Progress: 1900-1991.” In A History of Ozark County, 18411991, ed. Shirley Carter Piland. Gainesville, MO: Ozark County Genealogical and Historical Society, 1991.

Roll, Jarod. Spirit of Rebellion: Labor and Religion in the New Cotton South. Urbana: University of Illinois Press, 2010.

Russell, Charles Taze. The Finished Mystery, Studies in the Scriptures, Series VII. Brooklyn, NY: International Bible Students Association, 1918.

Sanders, Elizabeth. Roots of Reform: Farmers, Workers, and the American State, 1877-1917. Chicago: University of Chicago Press, 1999.

Schwartz, Marvin. In Service to America: A History of VISTA in Arkansas, 1965-1985. Fayetteville: University of Arkansas Press, 1988.

Scott, James C. Seeing Like a State: How Certain Schemes to Improve the Human Condition Have Failed. New Haven: Yale University Press, 1998.

Senn, Gerald. "'Molders of Thought, Directors of Action': The Arkansas Council of Defense, 1917-1918.” Arkansas Historical Quarterly 36 (Fall 1977).

Shapiro, Henry D. Appalachia on Our Mind: The Southern Mountains and Mountaineers in the American Consciousness. Chapel Hill: University of North Carolina Press, 1978.

Shideler, James H. Farm Crisis, 1919-1923. Berkeley: University of California Press, 1957.

Shiras, Frances. "Norfork Dam.” Arkansas Historical Quarterly 4 (Summer 1945). 
Smith, Zachary. "Tom Watson and Resistance to Federal War Policies in Georgia during World War I." Journal of Southern History 78 (May 2012).

Stapleton, Isaac. Moonshiners in Arkansas. Independence, MO: Zion's Printing and Publishing Co., 1948.

Stewart, Bruce E. Moonshiners and Prohibitionists: The Battle Over Alcohol in Southern Appalachia. Lexington: University of Kentucky Press, 2011.

Stock, Catherine McNicol, and Robert D. Johnston, ed. The Countryside in the Age of the Modern State: Political Histories of Rural America. Ithaca: Cornell University Press, 2001.

Straw, Richard A., and H. Tyler Blethen, eds. High Mountains Rising: Appalachia in Time and Place. University of Illinois Press, 2004.

Strom, Claire. "Editorials and Explosions: Insights into Grassroots Opposition to Tick Eradication in Georgia, 1915-1920." Georgia Historical Quarterly 88 (Summer 2004). . Making Catfish Bait Out of Government Boys: The Fight Against Cattle Ticks and the Transformation of the Yeoman South. Athens: University of Georgia Press, 2009.

--------. "Texas Fever and the Dispossession of the Southern Yeoman Farmer." Journal of Southern History 66 (February 2000).

Sutton, Keith, e.d. Arkansas Wildlife: A History. Fayetteville: University of Arkansas Press, 1998.

Thomas, Jerry Bruce. An Appalachian Reawakening: West Virginia and the Perils of the New Machine Age, 1945-1972. Morgantown: West Virginia University Press, 2010.

Thompson Jr., Charles D. Spirits of Just Men: Mountaineers, Liquor Bosses, and Lawmen in the Moonshine Capital of the World. Urbana: University of Illinois Press, 2011.

Tindall, George B. The Emergence of the New South, 1913-1945. Baton Rouge: Louisiana State University Press, 1967. , ed. A Populist Reader: Selections from the Works of American Populist Leaders. New York: Harper Torchbooks, 1966.

Vance, Rupert. “A Karl Marx for Hill Billies.” Social Forces 9 (December 1930).

Wagy, Tom. "Little Sam Faubus: Hillbilly Socialist." Arkansas Historical Quarterly 53 (Autumn 1994). 
Waller, Altina L. Feud: Hatfields, McCoys, and Social Change in Appalachia, 1860-1900. Chapel Hill: University of North Carolina Press, 1988.

Warren, Luther E. Yellar Rag Boys: The Arkansas Peace Society of 1861 and Other Events in Northern Arkansas, 1861 to 1865. Marshall, AR: Sandra L. Weaver, 1993.

Webb, James. Born Fighting: How the Scots-Irish Shaped America. New York: Broadway Books, 2004.

Weise, Robert S. Grasping at Independence: Debt, Male Authority, and Mineral Rights in Appalachian Kentucky, 1850-1915. Knoxville: University of Tennessee Press, 2001.

Willis, James F. Southern Arkansas University: The Mulerider School's Centennial History, 1909-2009. Magnolia, AR: Southern Arkansas University Foundation, 2009.

---------. “The Cleburne County Draft War.” Arkansas Historical Quarterly 26 (Spring 1967).

Wilson, Gregory S. Communities Left Behind: The Area Redevelopment Administration, 19451965. Knoxville: University of Tennessee Press, 2009.

Whayne, Jeannie M. A New Plantation South: Land, Labor, and Federal Favor in TwentiethCentury Arkansas. Charlottesville: University Press of Virginia, 1996.

-------. "Prosperity Eluded: Era of Transition, 1880-1900." In Arkansas: A Narrative History, ed. Jeannie M. Whayne, Thomas A. DeBlack, George Sabo III, and Morris S. Arnold. Fayetteville: University of Arkansas Press, 2002.

Whayne, Jeannie M., Thomas A. DeBlack, George Sabo III, and Morris S. Arnold, eds. Arkansas: A Narrative History. Fayetteville: University of Arkansas Press, 2002.

Williams, John Alexander. Appalachia: A History. Chapel Hill: University of North Carolina Press, 2002.

Wolf, John Quincy. Life in the Leatherwoods, ed. Gene Hyde and Brooks Blevins. Fayetteville: University of Arkansas Press, 2000.

Woodrell, Daniel. "How Much of the Ozarks is in Me?" In "Reading Group Guide" of Daniel Woodrell, The Death of Sweet Mister. 2001; New York: Back Bay Books, 2012.

Woodward, C. Vann. Origins of the New South, 1877-1913. Baton Rouge: Louisiana State University Press, 1951.

Worley, Ted R. "Documents Relating to the Arkansas Peace Society of 1861." Arkansas Historical Quarterly 17 (Spring 1958). 
--------. “The Arkansas Peace Society of 1861: A Study in Mountain Unionism.” Journal of Southern History 24 (November 1958).

\section{Unpublished Theses, Dissertations, and Papers:}

Adams, J. Brett. “The Polk County Rebellion.” Unpublished conference paper, Third Annual Ozarks Studies Symposium, West Plains, Missouri, September 2009.

Brake, Elizabeth. “'Commendably Democratic' and 'Intensely Practical'? Federal Farm Policy Administration and the County ASCS Committees." Unpublished conference paper, Southern Historical Association $77^{\text {th }}$ Annual Meeting. Baltimore, Maryland. October 2011.

Deatherage, Todd. "World War I Draft Evasion and the Ozark Mountain Draft Wars." Unpublished student paper, University of Arkansas, 1989.

Eddleman, Janice Bufford. "Who Killed Grandpa Charley? The Independence County Tick War and the Murder of Charles Jeffrey." Unpublished research paper, n.d.

Gordon Jr., Leland P. "The Ozarks Regional Commission and Its Impact in Arkansas." Unpublished graduate internship paper, University of Arkansas, 1973.

Henningson, Randy. "Upland Farmers and Agrarian Protest: Northwest Arkansas and the Brothers of Freedom." MA thesis, University of Arkansas, 1973.

Hernando, Matthew. "The Bald Knobbers of Southwest Missouri, 1885-1889: A Study of Vigilante Justice in the Ozarks.” PhD dissertation, Louisiana State University, 2011.

Nielson, Ann. "A Comparison of the Regional Planning Approaches of the Appalachian and Ozarks Regional Commissions.” M.A. thesis, University of Oklahoma, 1970.

Seagraves, Joe T. “Arkansas Politics, 1874-1918.” PhD dissertation, University of Kentucky, 1973.

Sealander, Judith. "Draft Evasion in the South during the First World War." M.A. thesis, University of Arkansas, 1973.

\section{Internet Sources:}

Ancestry.com. American Civil War Regiments [online database]. Provo, UT: Ancestry.com Operations, Inc., 1999. 
--------. Arkansas Confederate Pension Records, 1891-1935 [online database]. Provo, UT: Ancestry.com Operations, Inc., 2011.

--------. Arkansas, County Marriages Index, 1837-1957 [online database]. Provo, UT:

Ancestry.com Operations, Inc., 2011.

--------. Fort Smith, Arkansas, Criminal Case Files, 1866-1900 [online database]. Provo, UT: Ancestry.com Operations, 2012.

--------. U.S. Civil War Pension Index: General Index to Pension Files, 1861-1934 [online database]. Provo, UT: Ancestry.com Operations, 2000.

-------. World War I Draft Registration Cards, 1917-1918 [database on-line]. Provo, UT: Ancestry.com Operations Inc, 2005.

Arsenault, Raymond. "Jeff Davis (1862-1913)." Encyclopedia of Arkansas History and Culture http://www.encyclopediaofarkansas.net/encyclopedia/entry-detail.aspx?entryID=98.

Barth, Jay. "Democratic Party." Encyclopedia of Arkansas History and Culture http://www.encyclopediaofarkansas.net/encyclopedia/entry-detail.aspx?entryID=593.

Berry, Evalena. "Cleburne County." Encyclopedia of Arkansas History and Culture. http://www.encyclopediaofarkansas.net/encyclopedia/entry-detail.aspx?entryID=756.

Bissett, Jim. "Socialist Party." Encyclopedia of Oklahoma History and Culture. http://digital.library.okstate.edu/encyclopedia/entries/S/SO001.html.

Blakley, Dee. “John Thomas Burris.” Shakin' the Family Tree. http://wc.rootsweb.ancestry.com/cgi-bin/igm.cgi?op=GET\&db=sharpchick\&id=156.

Bruce, Shane. "The Legend of Harve Bruce (My Great Grandpa)." Bludgeon and Skewer. Posted May 10, 2012. http://bludgeonandskewer.blogspot.com/2012_05_01_archive.html.

"Captain Benjamin Franklin Taylor." In Ancestors of Jody Lawrence Drewry: Notes. http://www.angelfire.com/ut2/jldrewry/Jody/pafn07.htm.

Dave Liep's Atlas of U.S. Presidential Elections. http://uselectionatlas.org/RESULTS/.

Dillard, Tom W. "Winthrop Rockefeller (1912-1973)." Encyclopedia of Arkansas History and Culture. http://www.encyclopediaofarkansas.net/encyclopedia/entrydetail.aspx?entryID $=122$.

“Dr. Bill Smith.” Biographical profile. https://www.linkedin.com/in/ozarkguru.

Dumas, Ernest. "Bullfrog Valley Gang." Encyclopedia of Arkansas History and Culture. http://www.encyclopediaofarkansas.net/encyclopedia/entry-detail.aspx?entryID=7378.

Frauenthal, Jeannie. "Max Frauenthal (1836-1914)." Encyclopedia of Arkansas History and Culture. http://www.encyclopediaofarkansas.net/encyclopedia/entrydetail.aspx?entryID $=3184$. 
Hanson, Aprille. "Student Begins His Political Career in Mountain Home." Arkansas Catholic.org. December 4, 2010. http://www.arkansas-catholic.org/news/article/2371.

Hild, Matthew. "Brothers of Freedom." Encyclopedia of Arkansas History and Culture http://www.encyclopediaofarkansas.net/encyclopedia/entry-detail.aspx?entryID=6990.

"John Boozman for Senate Campaign News Conference, July 6, 2010." C-SPAN.org. http://www.c-span.org/video/?294383-1/john-boozman-senate-campaign-newsconference-.

Johnston, James J. "Searcy County.” Encyclopedia of Arkansas History and Culture. http://www.encyclopediaofarkansas.net/encyclopedia/entry-detail.aspx?entryID=806.

"Karen S. Hopper." State House of Representatives profile. http://www.arkansashouse.org/member/232/Karen\%20S.-Hopper.

Kirkpatrick, Matthew B. "Washington County." Encyclopedia of Arkansas History and Culture. http://www.encyclopediaofarkansas.net/encyclopedia/entry-detail.aspx?entryID=813.

"Mary Ann Caster, Real Estate Agent, Gilbert Realty Co." GilbertRealty.com. http://www.gilbertrealty.com/marylist.htm.

Miller, C.J. "Carroll County." Encyclopedia of Arkansas History and Culture. http://www.encyclopediaofarkansas.net/encyclopedia/entry-detail.aspx?entryID=752.

Mulloy, Clement. "Mountain Home (Baxter County)." Encyclopedia of Arkansas History and Culture. http://www.encyclopediaofarkansas.net/encyclopedia/entrydetail.aspx? entryID $=826$.

Orr, Nancy. "Sharp County." Encyclopedia of Arkansas History and Culture. http://www.encyclopediaofarkansas.net/encyclopedia/entry-detail.aspx?entryID=809.

"Ozark Tea Party in Mountain Home AR." Video posted at http://www.youtube.com/watch?v=9R0OzTSaH6Q.

Pierce, Michael Pierce. "Labor Movement." Encyclopedia of Arkansas History and Culture. http://www.encyclopediaofarkansas.net/encyclopedia/entry-detail.aspx?entryID=4235.

Reed, Bernard. "Shooting of Gordon Kahl." Encyclopedia of Arkansas History and Culture. http://www.encyclopediaofarkansas.net/encyclopedia/entrydetail.aspx?entryID $=5483$.

"Resume: Dr. Bill Smith (Ozark Guru).” http://agora-assoc.com/smithresume.html.

Risener, Lynn Banard. “Original Grantee's Land, Van Buren County, Arkansas: Township 11N, Range 17W." http://www.rootsweb.ancestry.com/ arvanbur/LandRecords/111.

Sanders-Gray, Sherry. "Marion County." Encyclopedia of Arkansas History and Culture. http://www.encyclopediaofarkansas.net/encyclopedia/entry-detail.aspx?entryID=789. 
Smith, Bill. "Ozark Tea Party—Mountain Home, Arkansas." Advertisement posted at FairTaxNation.com. March 26, 2009. http://www.fairtaxnation.com/profiles/blogs/ozarktea-party-mountain-home.

South Shore Foundation. A Pictorial History of Bull Shoals Dam and the Town of Bull Shoals. Flippin, AR: South Shore Foundation, 2002. Online at http://www.southshore.com/bsdam.htm.

---------. South Shore Memory Project Archives. http://ozarkhistory.com/archive/SouthShore/.

"The Legend of Harve Bruce." OakSpringsMountainRanch.com. http://oakspringsmountainranch.com/Legend_of_Harve_Bruce.html.

Yount, Shelia. "Clyde Taylor Ellis (1908-1980)." Encyclopedia of Arkansas History and Culture. http://www.encyclopediaofarkansas.net/encyclopedia/entrydetail.aspx?entryID $=2532$. 